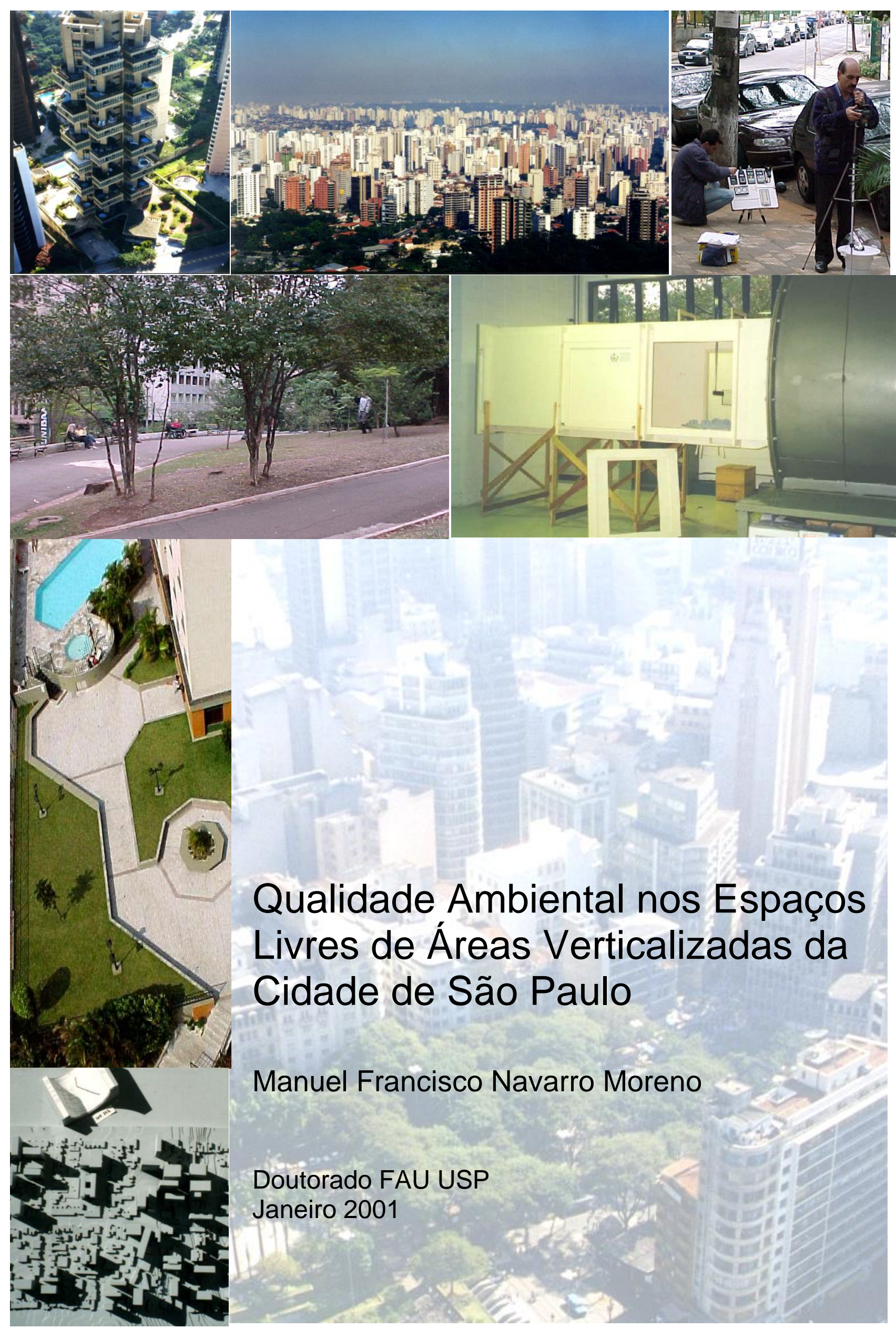




\title{
Qualidade Ambiental nos Espaços Livres em Áreas Verticalizadas da Cidade de São Paulo
}

\author{
Manuel Francisco Navarro Moreno
}

Tese apresentada à Faculdade de Arquitetura e Urbanismo da Universidade de São Paulo para a obtenção do título de Doutor em Arquitetura e Urbanismo.

Área de Concentração: Estruturas Ambientais Urbanas.

Sub Área: Paisagem e Ambiente

Orientador: Dr Silvio Soares Macedo

São Paulo Janeiro 2001 

À Teruko pelos 25 anos de caminhada conjunta e por mostrar que a realidade está sendo melhor do que a que tínhamos sonhado. 


\section{Agradecimentos}

Ao Silvio Soares Macedo pela amizade e paciência, muito mais que orientador nos ajudou a enfrentar as incertezas e as devastadoras autocríticas.

À Teruko, Milene e Michel que ao invés de terem a constante presença do marido e pai, freqüentemente me apoiaram e ajudaram como a um filho.

À Márcia Peinado Alucci e Alexandre Emilio Lipai pelas profícuas trocas de idéias, que consolidam três décadas de amizade, desde quando convivíamos na FAU e IPT.

Ao Dr. Marcos Tadeu Pereira, chefe do Laboratório de Vazão, do IPT, Engenheiros, Técnicos e Funcionários, que além de abrir as portas, dedicaram amizade fazendome sentir parte da equipe como se estivesse com eles há muitos anos.

À Dra. Maria Akutsu e ao corpo técnico da Divisão de Engenharia Civil do IPT pela atenção e objetividade de suas sugestões.

Ao Dr. Jorge A. Gil Saraiva, coordenador do Núcleo de Dinâmica Aplicada do Laboratório Nacional de Engenharia Civil de Portugal, pela visita que nos fez e preciosas informações.

Ao Sr. Getulio Chofard, mantenedor da Universidade Ibirapuera, por disponibilizar a infra-estrutura do Laboratório de Ensaios, Maquetes e Protótipos do Curso de Arquitetura e Urbanismo, para construirmos a câmara de testes do Túnel de Vento.

Ao Programa de Apoio à Qualificação Docente da Universidade de Mogi das Cruzes pelos trinta e seis meses de bolsa auxílio.

Ao Professor Fabio Romeu de Carvalho, Pró Reitor Administrativo da Universidade Paulista, pelo afastamento do cargo de Coordenador.

Aos colegas Arquitetos Antero de Oliveira Cruz, Miguel Torrero e Carlos Silva, pela participação direta na criação dos equipamentos, nas pesquisas e na elaboração do material final.

À todos que mesmo sem uma manifestação mais concreta, estavam torcendo por mim porque acreditam em minhas possibilidades.

À todos, muito obrigado.

MANUEL FRANCISCO NAVARRO MORENO 


\section{Resumo}

Este trabalho versa sobre a verticalização em São Paulo e seus impactos sobre a qualidade ambiental dos espaços livres. Parte-se do pressuposto de que a não compreensão, por parte do corpo técnico e da população em geral, dos problemas resultantes da verticalização (tais como: sombreamentos, canalização de ventos, alteração da umidade do ar, maior aquecimento e agravamento da poluição) piora a qualidade ambiental dos espaços livres. No corpo do trabalho são introduzidos os procedimentos básicos para o aprimoramento da qualidade ambiental, que devem ser conhecidos e aplicados normalmente no projeto dos espaços livres.

Os espaços livres públicos, como as vias, praças e parques, assim como os espaços privados, que são os espaços livres existentes nos lotes, em torno das edificações; têm perdido sua habitabilidade em conseqüência da verticalização e do adensamento urbano, mesmo com a aplicação da atual legislação de uso e ocupação do solo. Implantada em 1972, ela gera espaços livres mais generosos do que anteriormente, com a obrigatoriedade de novos recuos e menores taxas de ocupação. Esta legislação ao determinar espaços livres um pouco maiores, cria condições para que os incorporadores agreguem, aos seus empreendimentos, equipamentos para o lazer, mesmo que essas áreas sejam ambientalmente inadequadas.

A qualidade ambiental resultante é analisada sob o aspecto perceptivo-sensorial, considerando-se a influência que o Meio Urbano Verticalizado (malha viária, espaços livres, quadras, lotes e edificações) tem sobre as variáveis ambientais do Meio Natural (radiação solar, ar, água, solo, vegetação e fauna).

As variáveis ambientais são analisadas em cinco regiões com bairros densamente verticalizados: a) Centro: Higienópolis; b) Norte: Freguesia do Ó; c) Sul: Moema; d) Leste: Vila Gomes Cardim; e) Oeste: Perdizes.

Como resultado, são apresentadas recomendações, implementáveis no processo de projeto, para melhorar a qualidade ambiental nos espaços livres urbanos de áreas verticalizadas. 


\section{Abstract}

This thesis turns on the verticalization in São Paulo and its impacts on the environmental quality of free spaces. It breaks of the presupposition that the nonunderstanding, on the part of the technical body and of the population in general, of the resulting problems of the verticalization (such as shadows, canalization of winds, alteration of the humidity of the air, larger heating and worsening of the pollution) worsens the environmental quality of free spaces. In the body of the work the basic procedures are introduced to increase the environmental quality that should be known and usually applied in the project of such spaces.

The public free spaces, as roads, squares and parks; as well as the private spaces, that are the existent free spaces in the lots, around the constructions; they have been losing its inhabitability in consequence of the verticalization and the increase of the urban areas, even with the application of the current legislation on use and occupation of the soil. Implanted in 1972, it generates more generous free spaces than previously, with the obligation of new recoils and smaller occupation rates. This legislation when establishing free spaces a little larger, it creates conditions so that the incorporators joins, to its enterprises, equipments for leisure, even if those areas are functionally inadequate for such, even if they never receive sun light or that make funnel-shaped and accelerate the winds.

The resulting environmental quality is analyzed under the perceptive-sensorial aspect, considering the influence that the Verticalized Urban Way (its street ensemble, free spaces, blocks, lots and constructions) has on the environmental variables of the Natural Way (solar radiation, air, water, soil, vegetation and fauna).

The analysis are applied to five areas with neighborhoods densely verticalized: a) Center: Higienópolis; b) North: Freguesia do Ó; c) South: Moema; d) East: Vila Gomes Cardim; e) West: Perdizes.

As result, recommendations presented, to be used in the project process, to improve the environmental quality in the urban free spaces of verticalized areas. 


\section{Sumário}

\section{Introdução}

1.1 A Cidade de São Paulo

1.2 A Verticalização na Cidade de São Paulo

4

1.3 Os Espaços Livres em Áreas Verticalizadas 6

1.4 A Qualidade dos Espaços Livres $\quad 7$

1.5 Estudos Precedentes 9

1.6 Sistemas de Relações formam os Contextos da Realidade 14

1.7 Percepção: a Realidade em nossa Mente 16

1.8 O Enfoque do Arquiteto 18

1.9 Intervenções Arquitetônicas e Urbanísticas na Qualidade Ambiental 19

1.9.1 Múltiplas Intervenções ao Longo de Décadas $\quad 19$

1.9.2 Intervenções Pontuais em Curto Prazo 24

2 Os Espaços Livres em Áreas Verticalizadas $\quad 27$

2.1 Os Padrões de Verticalização na Cidade de São Paulo 27

2.2 A Legislação Urbana na Cidade de São Paulo 32

2.3 Os Espaços Livres Resultantes 38

2.4 Normas Específicas sobre Variáveis Ambientais 45

2.4.1 Higiene Ambiental 46

$\begin{array}{ll}2.4 .2 \text { Clima } & 48\end{array}$

3 Caracterização Ambiental da Cidade de São Paulo 51

3.1 Conceituações para a Caracterização Ambiental 51

3.1.1 Conceituação das Características Morfológicas Naturais 52

3.1.2 Conceituação das Características Morfológicas Urbanas 56

3.1.3 Características de Higiene Ambiental 59

3.1.4 Características Climáticas 62

3.2 Caracterização Ambiental da Cidade de São Paulo 66

3.2.1 Morfologia Natural de São Paulo 66

3.2.2 Morfologia Urbana de São Paulo 68

3.2.3 Implicações na Higiene Ambiental de São Paulo 74

3.2.4 Implicações Climatológicas em São Paulo 80

4 Análise da Qualidade Ambiental Local 83

4.1 Iluminação $\quad 84$

4.1.1 Higienópolis $\quad 84$

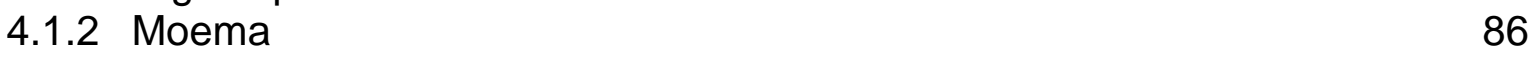

4.1.3 Recomendações 88

4.2 Ruídos $\quad 89$

4.2.1 Moema $\quad 89$

4.2.2 Higienópolis $\quad 91$

4.2.3 Recomendações 92

$\begin{array}{lll}4.3 & \text { Cinestesia } & 94\end{array}$

4.3.1 Constatações de Inadequações Cinestésicas 94

4.3.2 Recomendações 96

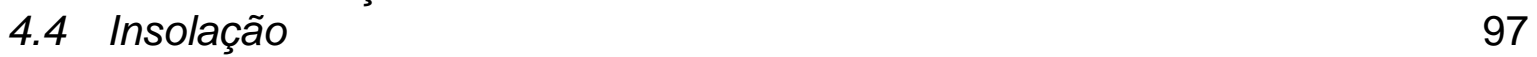

4.4.1 Perdizes 97 
4.4.2 Vila Gomes Cardim 99

$\begin{array}{ll}\text { 4.4.3 Moema } & 101\end{array}$

4.4.4 Higienópolis 103

4.4.5 Recomendações 105

4.5 Ventos 105

4.5.1 Higienópolis 105

$\begin{array}{ll}\text { 4.5.2 Moema } & 107\end{array}$

4.5.3 Recomendações 108

$\begin{array}{lll}4.6 & \text { Umidades } & 108\end{array}$

4.6.1 Higienópolis e Moema 108

4.6.2 Recomendações 109

4.7 Sensação Térmica e Variáveis Climáticas 109

4.7.1 Análises dos Estudos de Casos 110

5 Procedimentos e Instrumental de Análise 115

5.1 Procedimentos de Análise $\quad 115$

5.1.1 Levantamento Morfológico $\quad 116$

5.1.2 Quantificação das Variáveis Ambientais $\quad 117$

$\begin{array}{ll}5.2 \text { Instrumental } & 118\end{array}$

5.2.1 lluminação 118

5.2.2 Ruído 121

5.2 .3 Insolação 121

5.2.4 Ventos 123

5.2.5 Umidades e Temperaturas 123

5.3 Túnel de Vento de Camada Limite Atmosférica 124

5.3.1 O Uso de Túneis de Vento em Geral 125

5.3.2 Aplicações de Túneis de Vento Atmosféricos 126

5.3.3 A Parceria com o Laboratório de Vazão do IPT 127

5.3.4 Construção da Câmara de Testes 130

5.3.5 Conceitos e Procedimentos 132

5.3.6 A Velocidade de Referência 137

5.3.7 Visualização 138

5.3.8 Descrição dos Testes Realizados 140

5.3.9 Adquirindo Sensibilidade para Interpretar os Testes 141

5.3.10 Considerações Finais $\quad 148$

6 Conclusões 149

7 Bibliografia $\quad 153$

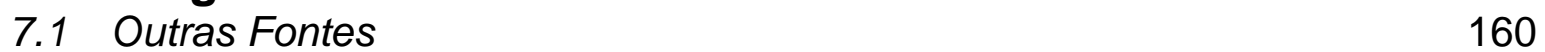

7.1.1 Normas Técnicas Brasileiras $\quad 160$

7.1.2 Normas Técnicas Internacionais 162

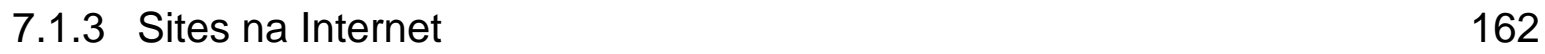

8 Glossário 163

9 Anexos 170

9.1 Anexo A: Caracterização Física e Ambiental de São Paulo 170

9.2 Anexo B: Maquetes Eletrônicas das Cinco Áreas de Análises 172

9.3 Anexo C: Análise da Qualidade Ambiental nos Espaços Livres 178

viii Qualidade Ambiental nos Espaços Livres de Areas Verticalizadas da Cidade de São Paulo MORENO, Manuel Francisco Navarro 


\section{Apresentação}

Este trabalho versa sobre a Verticalização e seus impactos sobre a Qualidade Ambiental dos Espaços Livres.

Parte-se do pressuposto de que sombreamentos, canalização de ventos, alteração da umidade do ar, maior aquecimento, concentração de poluentes, são problemas agravados pela Verticalização que pioram a Qualidade Ambiental dos Espaços Livres. O corpo técnico e a população em geral desconhecem os processos físicoambientais que originam esses problemas.

No capítulo Introdutório, a partir de enfoques perceptivos, contextuais-sistêmicos e ecológicos, examinam-se no tempo e no espaço, os problemas de Qualidade Ambiental em duas escalas de análise, a macro e a local.

O segundo capítulo conceitua os espaços livres na cidade de São Paulo e os analisa como resultantes, dos padrões de verticalização, da legislação urbana e das normas técnicas que abordam as variáveis ambientais, tais como: iluminação, ruídos, odores, poluição do ar, gases, partículas em suspensão e clima.

No terceiro capítulo examina-se a caracterização ambiental da cidade de São Paulo, em seus aspectos morfológicos (naturais e urbanos), da higiene ambiental do ar e climática.

O quarto capítulo apresenta análises da qualidade ambiental local, realizadas em cinco bairros densamente verticalizados da cidade de São Paulo. São introduzidos procedimentos de diagnóstico através de simulações e modelos físicos. O corpo do trabalho apresenta e reforça simulações (utilizando maquetes) dos fenômenos físicos e ambientais, que devem ser conhecidos e aplicados normalmente nos projetos dos espaços livres. Essas simulações são percebidas da mesma maneira que percebemos a realidade e isto consolida os conhecimentos e o repertório, de uma forma mais intuitiva do que racional. No processo criativo dos profissionais de 
projetos, os conhecimentos intuitivos fluem mais fáceis e rápidos do que os racionais e, portanto, têm mais chances de fazer parte do processo gerador da Arquitetura e do Urbanismo.

Os procedimentos e os instrumentos utilizados são detalhados no quinto capítulo. Descrevem-se os reconhecimentos morfológicos da Grande São Paulo concretizados com 0 uso de imagens de satélites, fotos aéreas, mapas cartográficos, sobrevôo de helicóptero e levantamentos fotográficos locais. As variáveis ambientais foram medidas com instrumentos eletrônicos como: luxímetro, decibelímetro e anemômetro; e também, com equipamentos por nós construídos, a exemplo do espelho do céu, termômetro de globo, relógio de Sol, as maquetes e o túnel de vento atmosférico. Complementarmente, relatam-se os experimentos realizados.

Como contribuição final, apresentamos recomendações para serem implementadas pelo Arquiteto e Urbanista, nas instâncias de Gestão Urbana e na Projetual. 


\section{Introdução}

\subsection{A Cidade de São Paulo}

À clássica afirmação de que São Paulo vivenciou três cidades em um século: a cidade Colonial, de taipa, do século XIX; a cidade Republicana, de tijolos; e a cidade Industrial, de concreto, consolidada no século XX; podemos agregar uma quarta: São Paulo como um núcleo das Corporações Trans Nacionais $(T N C)^{1}$, uma cidade em tempo real, centro de difusão de informações e decisões multinacionais.

São Paulo com seu crescimento vertiginoso abrigava, no ano 2000, quase 17 milhões de habitantes ${ }^{2}$ em sua área metropolitana, sendo considerada a terceira maior aglomeração populacional do planeta.

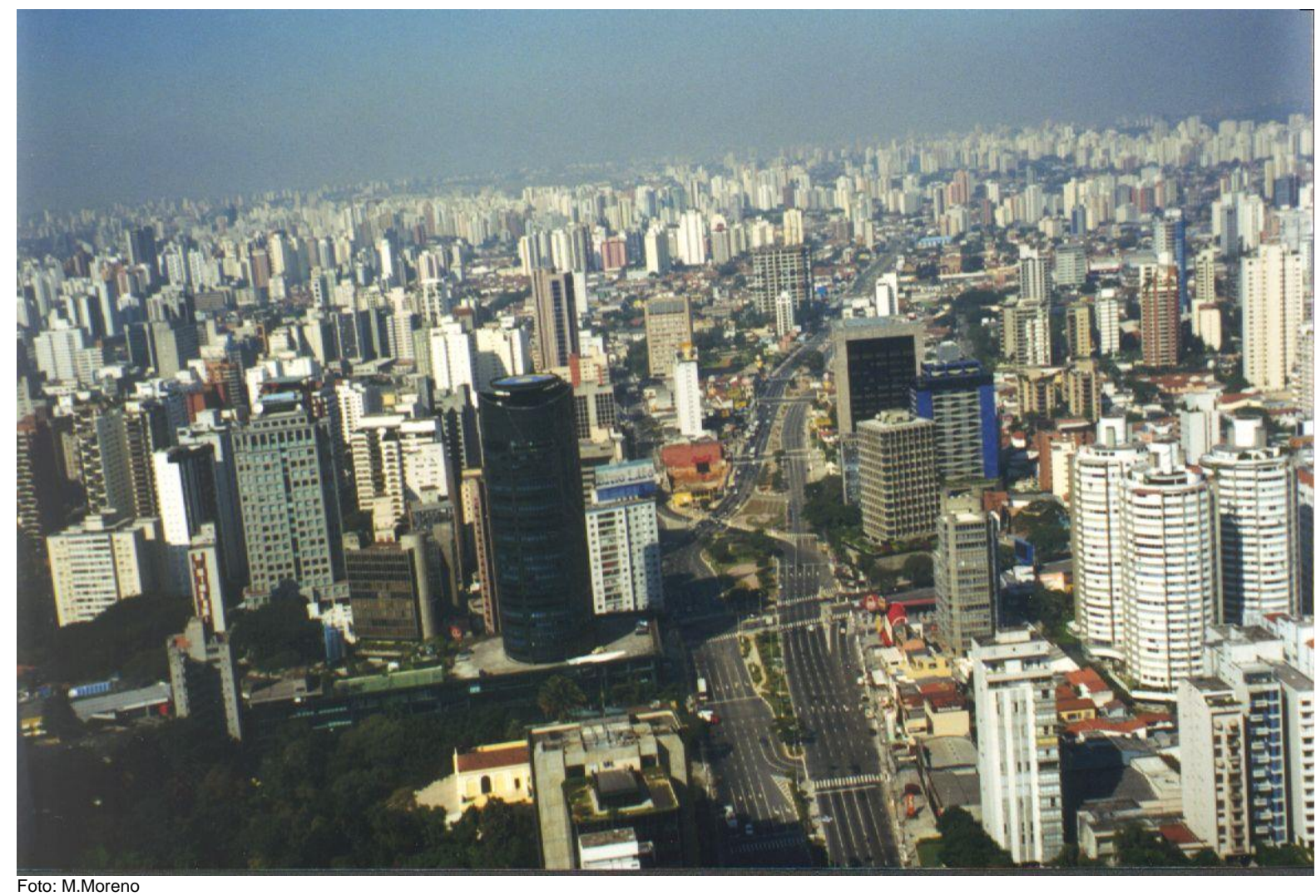

Figura 1-1: Vista da região sudeste da Cidade de São Paulo, a partir da Av. Brig. Faria Lima.

\footnotetext{
1 GRAHAM, Stephen, in Da Cidade de Pedra à Cidade Virtual (1996 p22). "As cidades podem ser consideradas como concentrações físicas que auxiliam na superação das restrições de tempo pela minimização das limitações de espaço. As telecomunicações... superam as restrições de espaço pela minimização das limitações de tempo, interligando pontos distantes através do fluxo de fótons e elétrons à velocidade da luz. A cidade em tempo real incorpora os atributos do espaço urbano e do ciber espaço eletrônico".

2 IBGE, estimativa por amostragem realizada em agosto de 1996.
} 


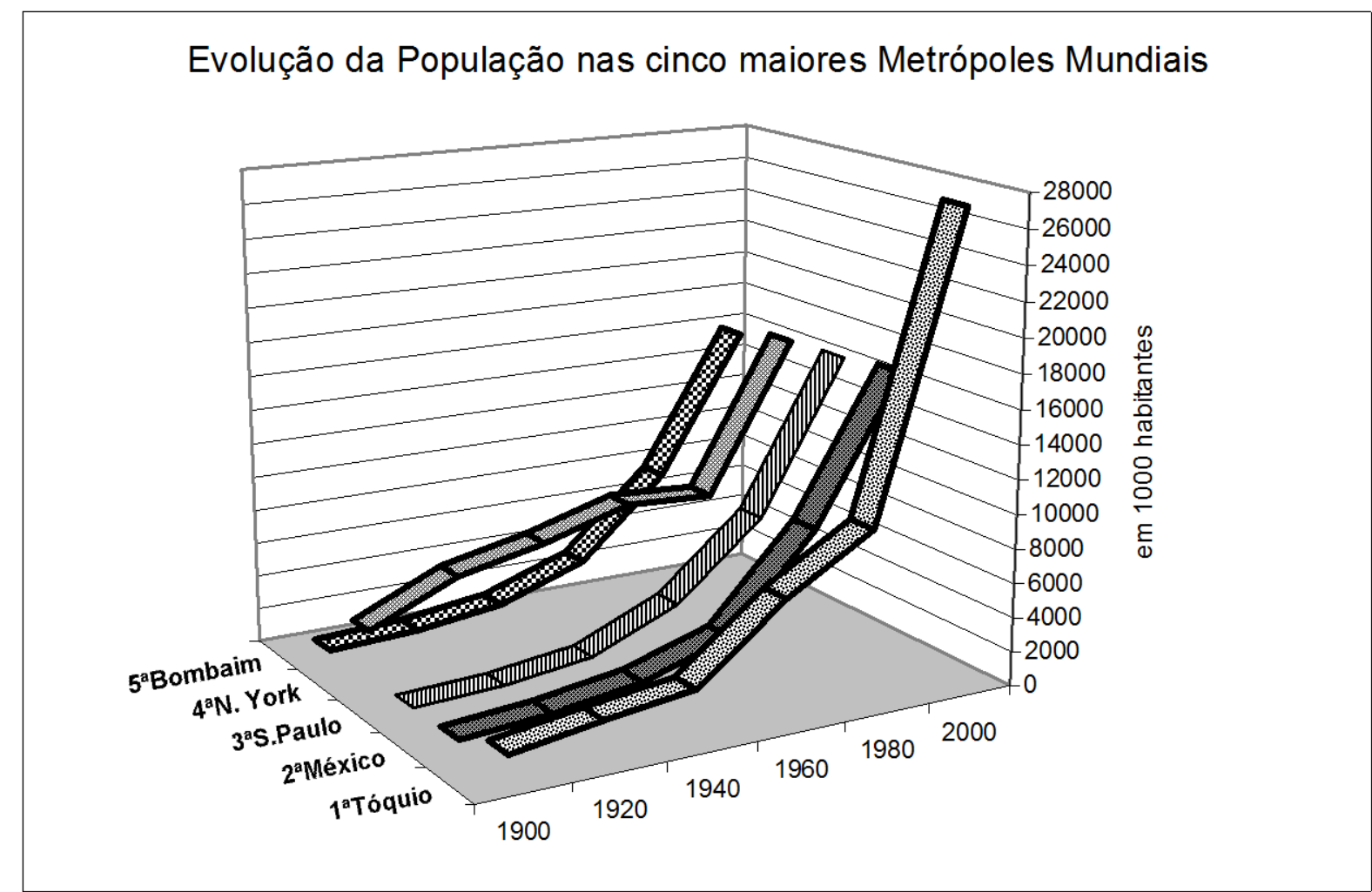

Quadro 1-1: Evolução da População nas cinco maiores Metrópoles Mundiais. (Fonte: ONU 1996)

Em A Estruturação da Grande São Paulo, Juergen Richard LANGENBUCH mostra o início da metropolização ${ }^{3}$ de 1920 a 1940, quando a população da cidade de São Paulo passou de 579.000 habitantes para 1.326.000, um aumento de $225 \%$. A efetivação da metropolização ocorre a partir de 1940, com a população chegando a 3,8 milhões de habitantes em 1960, com crescimento de $287 \%$. Essa fase se caracteriza pela expansão, verticalização e adensamento da área edificada, " $A$ compactação da cidade se verifica,... através de acentuado crescimento vertical no Centro e em vários bairros próximos: Santa Ifigênia, Campos Elíseos, Santa Cecília, Vila Buarque, Higienópolis, Consolação, Vila América, Paraíso, Liberdade, Aclimação e em menor escala em outros: Vila Mariana, Cambuci, Brás, mas abrangendo mesmo bairros afastados, entre os quais se destacam aqueles cujas porções centrais se estruturam em "subcentros": Santana, Penha, Pinheiros, Lapa." 4

\footnotetext{
3 LANGENBUCH, Juergen Richard (1971 p.170).

4 LANGENBUCH,(op.cit. p.179).
} 


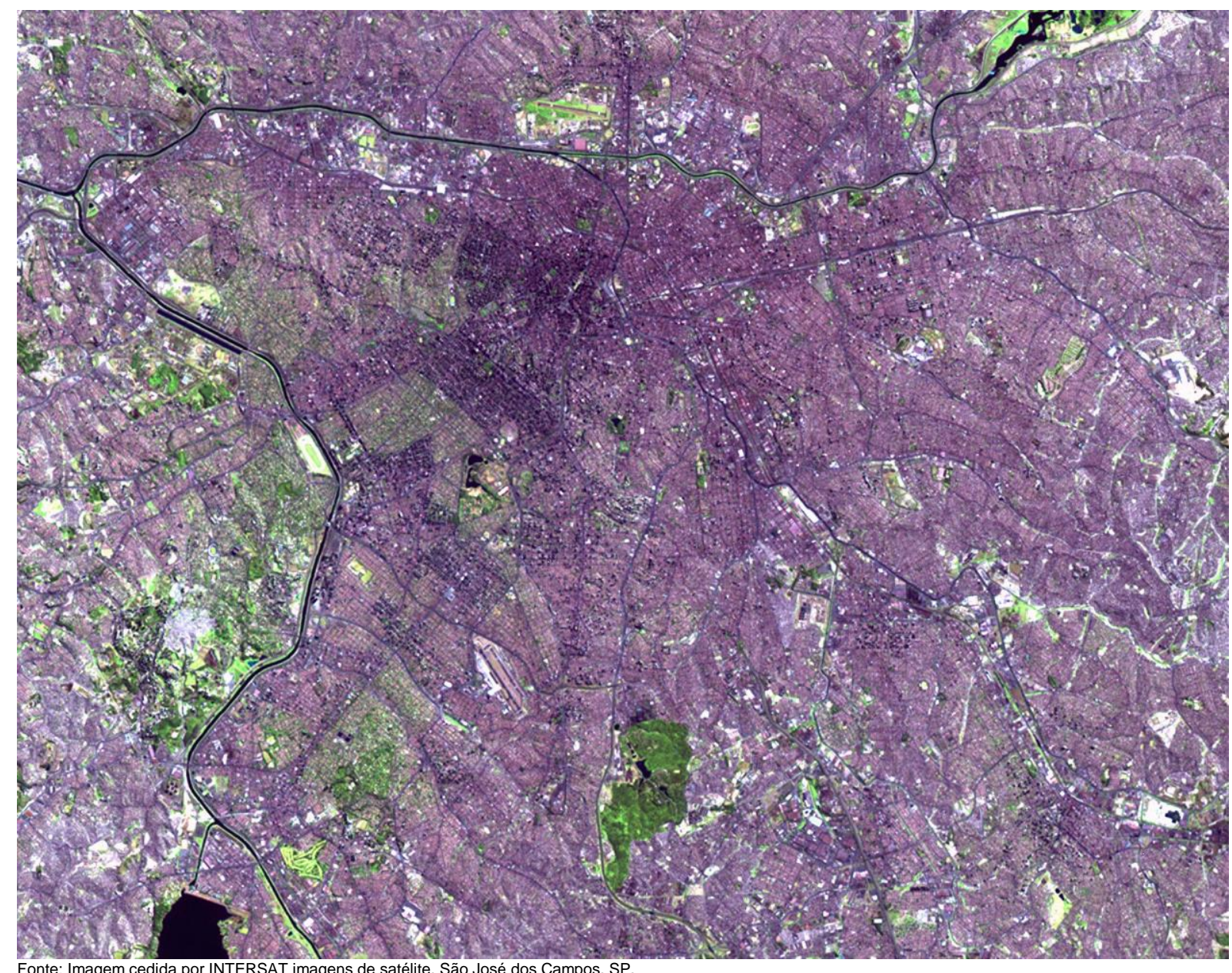

Figura 1-2: Imagem de satélite da Cidade de São Paulo e municípios limítrofes (1999). A mancha urbana aparece em lilás com as áreas verticalizadas em tom mais escuro.

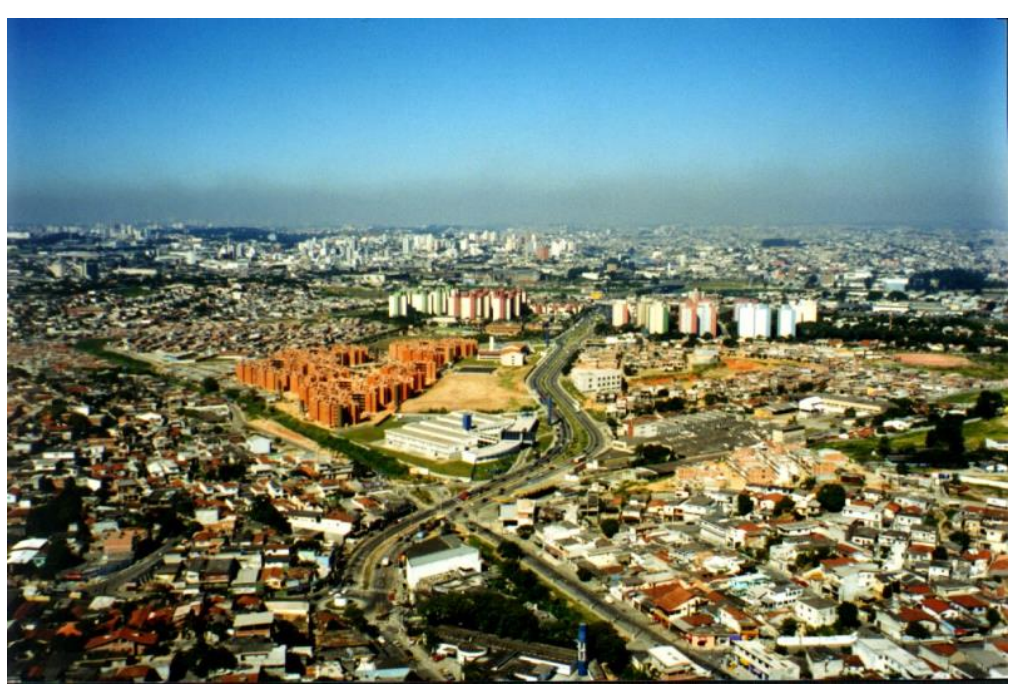

Foto: M.Moreno

Figura 1-3: Vista da Cidade de São Paulo, com o município de Osasco em primeiro plano.
No final do século $X X$, a verticalização prolifera em inúmeros pontos, de maneira irregular, por quase todos os 38 municípios que formam a Grande São Paulo. Na figura 1-3, pode-se ver a enorme diversidade de tipos de ocupação que formam o tecido urbano. 


\subsection{A Verticalização na Cidade de São Paulo}

A Metropolização a partir de 1940 e a Verticalização após 1950 são características fundamentais na urbanização da Cidade de São Paulo.

A redução da oferta de terrenos, nos bairros mais próximos do centro e com melhor infra-estrutura, encarece os lotes nessas áreas. A verticalização soluciona vários desses inconvenientes, permite melhor aproveitamento dos equipamentos urbanos, dilui por um número maior de usuários o custo do terreno e, por estar mais próximo do centro, favorece a redução do tempo de deslocamento.

Sob o ponto de vista tecnológico, a verticalização em São Paulo se viabiliza através da incorporação de novas tecnologias: o uso da estrutura de concreto armado, liberando as paredes da função estrutural, viabilizando a planta livre e a flexibilização dos espaços e o uso do elevador permite a construção de maior número de andares. Maria Adélia de SOUZA registra que o primeiro elevador na cidade foi instalado no Hospital Santa Catarina em $1918 .^{5}$

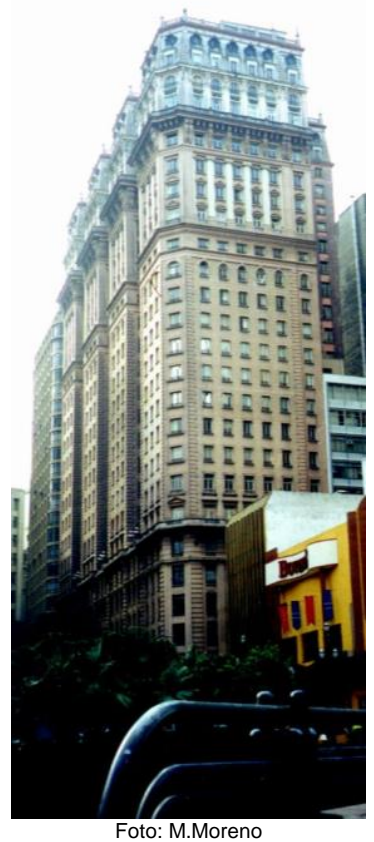

Ed. Martinelli

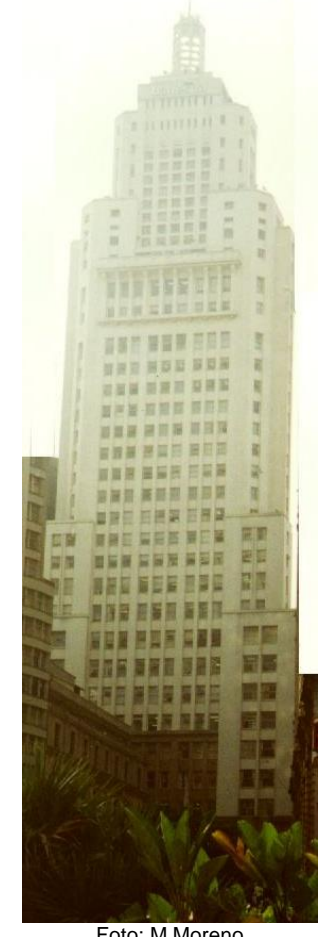

Ed. Banespa

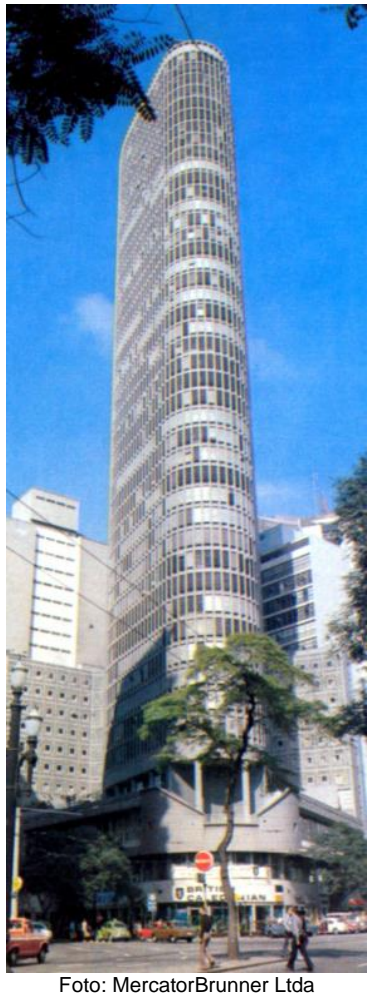

Ed. Itália

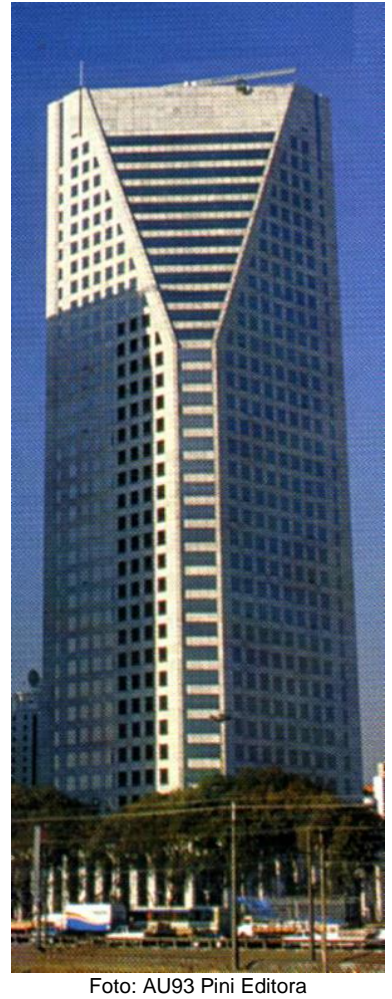

Ed. Torre Norte

Figura 1-4: Os marcos da Verticalização na Cidade de São Paulo.

\footnotetext{
${ }^{5}$ SOUZA, Maria Adélia Aparecida de (1994 p.89).
} 
Em tese, pelo mundo, a verticalização dos centros urbanos ocorre através de grandes arranha-céus comerciais e São Paulo, tanto segue essa regra, que os edifícios mais altos, símbolos da verticalização paulistana, são para escritórios. Cada um marcando sua época, como o Martinelli de 1929 com 26 andares e 105 metros de altura; o prédio do Banco do Estado de São Paulo de 1947, com 115m; e o Itália de 1956, com 160m e a Torre Norte do Centro Empresarial Nações Unidas, recém inaugurada (1999), que com seus $159 \mathrm{~m}$ de altura passou a ser o segundo maior edifício de São Paulo. Por outro lado a verticalização nas cidades brasileiras é tradicionalmente para moradia e o mercado imobiliário investe maciçamente na construção de prédios de apartamentos residenciais.

A implantação do BNH Banco Nacional da Habitação, após 1964, que financiou as incorporações de empreendimentos habitacionais, reforça em São Paulo a característica de verticalização com edifícios de apartamentos para moradia, tendência que predomina até hoje.
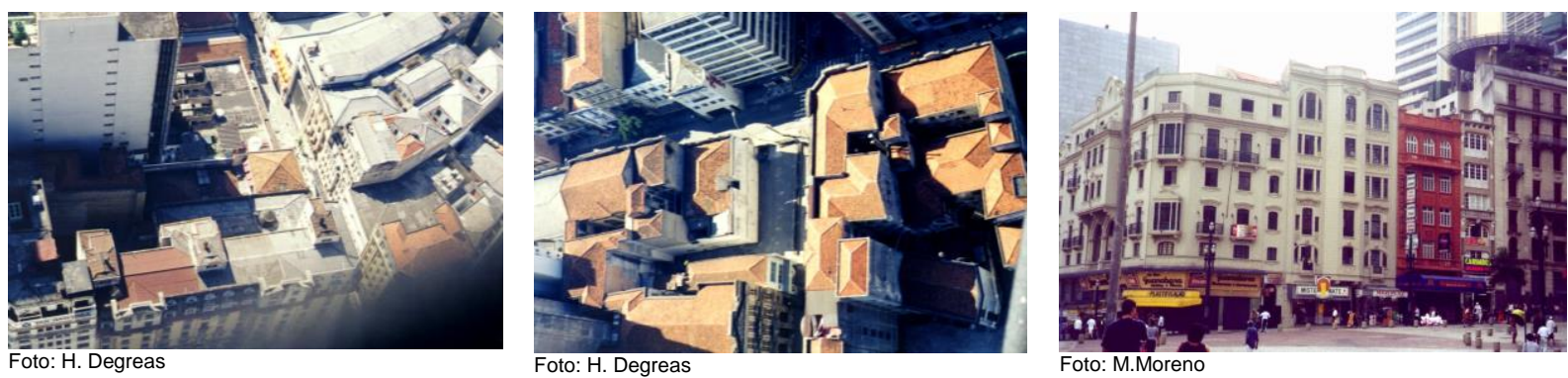

Figura 1-5: Implantação de edifícios geminados, típica até o início do século XX.

Os edifícios foram, a princípio, implantados dentro do formato de quadra bloco com edifícios geminados, o típico nas áreas centrais das principais cidades brasileiras. Neste tipo de implantação o prédio ocupa totalmente o terreno, tendo seus andares geminados com as construções vizinhas, contribuindo assim para uma série de inconvenientes de habitabilidade, principalmente quanto à insolação e à ventilação, tanto dos compartimentos internos, como dos espaços livres circunvizinhos.

O movimento urbanístico moderno brasileiro, nos anos 40 e 50, questiona vários desses inconvenientes e defende a implantação do edifício isolado no lote, inclusive em relação ao solo, através do uso dos pilotis. Como exemplo dos ideais modernistas de implantar as construções desvinculadas das divisas; temos as superquadras de Brasília, em que os edifícios estão rodeados de generosos espaços livres. 


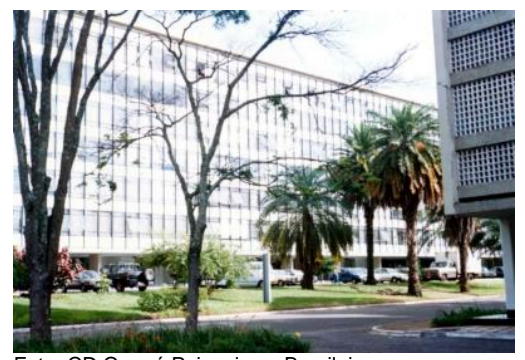

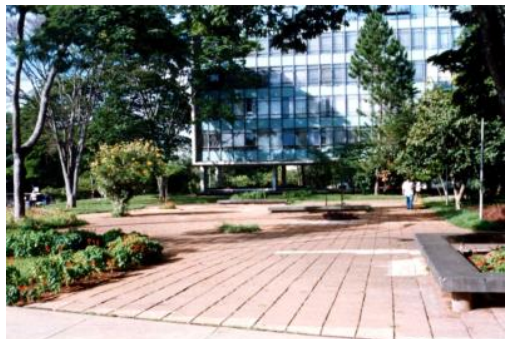

Foto: CD Quapá Paisagismo Brasileiro

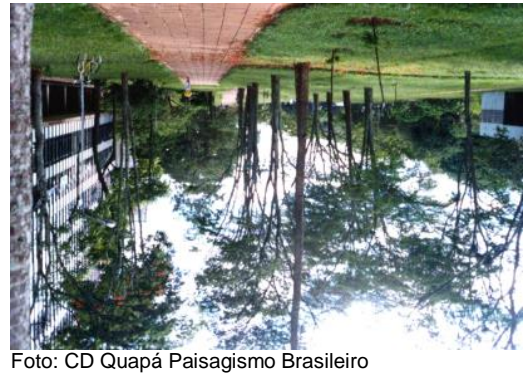

Foto: CD Quapá Paisagismo Brasileiro

Figura 1-6: Edifícios implantados entre jardins nas superquadras de Brasília.

\subsection{Os Espaços Livres em Áreas Verticalizadas}

Espaços Livres são todos aqueles espaços não contidos entre as paredes e tetos dos edifícios construídos pela sociedade ${ }^{6}$.

Na segunda metade deste século, a maioria das cidades brasileiras adota, em suas legislações, baixas taxas de ocupação do lote. $\mathrm{Na}$ cidade de São Paulo, a Lei de Zoneamento $\mathrm{n}^{0} 7805^{7}$, regulamentou o parcelamento, uso e ocupação do solo, oficializando os princípios modernistas de isolar o prédio no lote, princípios esses que já estavam sendo aplicados em vários loteamentos residenciais na cidade. As Taxas de Ocupação (TO), que anteriormente eram livres ou indefinidas pela legislação, passam a ser da ordem de $50 \%$, com recuos obrigatórios em todas as divisas, gerando a existência de generosos espaços livres privados.

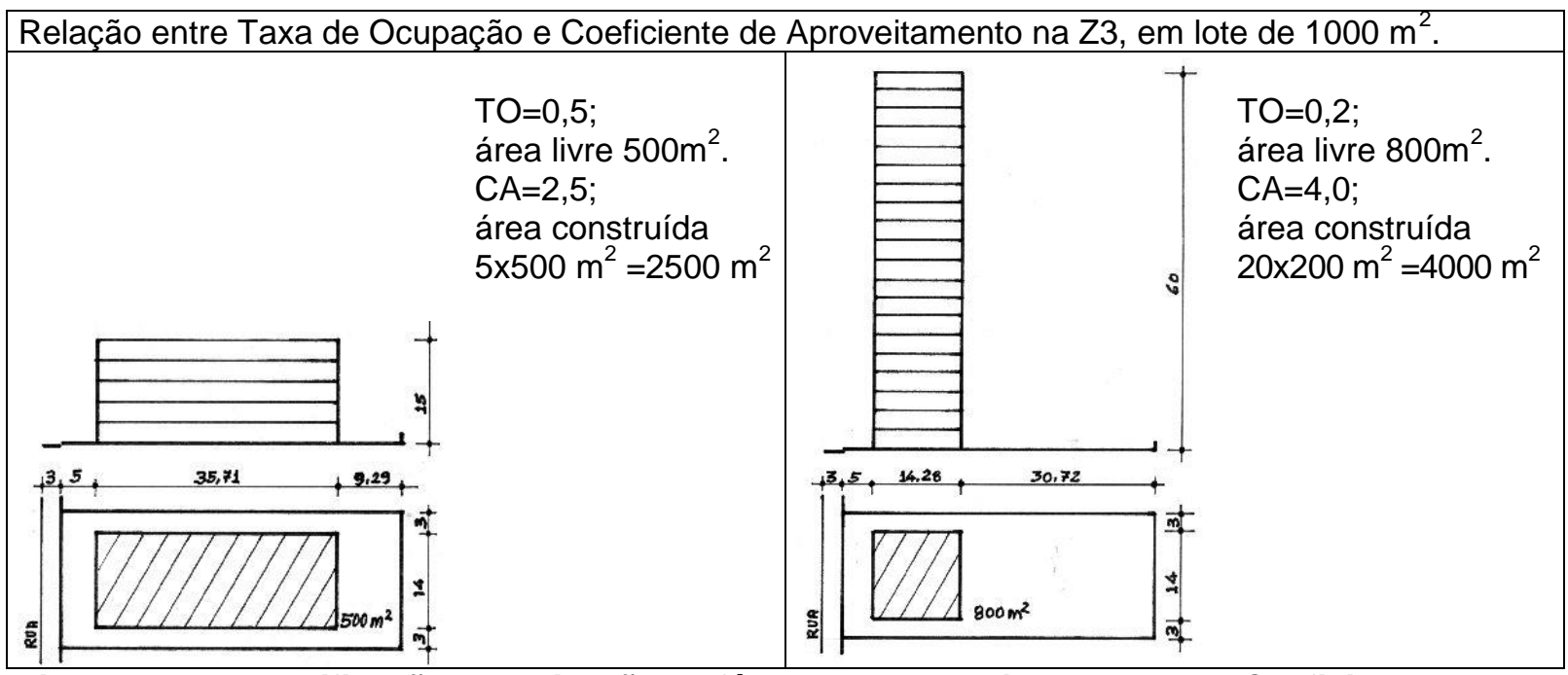

Figura 1-7: Exemplificação da aplicação da fórmula que permite aumentar o Coeficiente de Aproveitamento, desde que se reduza a Taxa de Ocupação.

\footnotetext{
6 MACEDO, Silvio Soares, Espaços Livres, (1995, p.1).

7 Lei no 7805, 1-11-1972, sobre o Parcelamento, Uso e Ocupação do Solo do Município de São Paulo.
} 
A Lei de Zoneamento, para edifícios de apartamentos (R2. 02), em seu artigo 24 permite o aumento do Coeficiente de Aproveitamento (CA), que seria 2,5 na Z3; 3,0 na Z4; e 3,5 na Z5; para até 4,0 vezes a área do terreno, desde que se aplique a fórmula $(\mathrm{c}=\mathrm{T} / \mathrm{t} \times \mathrm{C})^{8}$, a qual reduz a Taxa de Ocupação do lote, liberando mais espaços livres.

Como ilustração, apresenta-se um terreno de $1000 \mathrm{~m}^{2}$ (20m por $\left.50 \mathrm{~m}\right)$, na Z3, em duas situações: a) com TO $=0,5$, área livre de $500 \mathrm{~m}^{2}$, pode-se construir até $2500 \mathrm{~m}^{2}$, em 5 pavimentos de $500 \mathrm{~m}^{2}$, com CA =2,5; b) aplicando-se a fórmula e reduzindo-se TO para 0,2 , a área livre aumenta para $800 \mathrm{~m}^{2}$, podendo-se construir até $4000 \mathrm{~m}^{2}$, em 20 pavimentos de $200 \mathrm{~m}^{2}$ cada.

Isolar a construção no lote é conveniente para melhorar a insolação e a ventilação, principalmente em climas úmidos, como é o caso de São Paulo que durante oito meses do ano tem umidade relativa do ar elevada, porém, no caso de edifícios altos, que projetam grandes sombras, a ocorrência de problemas de inadequação dos espaços livres circundantes é muito freqüente, inviabilizando sua utilização para o lazer e, portanto, dos equipamentos neles instalados, como piscinas, playground, quiosques, quadras, churrasqueiras, etc...

\subsection{A Qualidade dos Espaços Livres}

O conceito de qualidade ambiental, em sentido amplo, está relacionado com o nível de satisfação que a pessoa obtém ao comparar as percepções do entorno, com suas expectativas, seus ideais e necessidades.

O adensamento urbano aumenta, no indivíduo, a insatisfação causada pelas dificuldades de deslocamento, originada pelos congestionamentos. São filas de pessoas, filas de veículos, restrições de circulação, restrições de acesso e aumento da ansiedade, da frustração e da insegurança por não poder, o cidadão, realizar o que tinha programado em virtude dos mais diversos empecilhos. $O$ adensamento construído e populacional implica no aumento de todos os tipos de Poluição: do Ar, da Água e do Solo, por gases, fuligens, fumaça, poeira, ruídos, odores, imagens, movimentos, calor, esgotos, efluentes, dejetos, lixo, etc... .Todas essas insatisfações repercutem negativamente na qualidade ambiental.

\footnotetext{
8 Formula de Adiron $(\mathrm{c}=\mathrm{T} / \mathrm{t} \times \mathrm{C}$ ) onde: $\mathrm{c}=$ coeficiente de aproveitamento a ser utilizado; $\mathrm{T}=$ taxa de ocupação máxima do lote (específica para cada Zona); $\mathrm{t}=$ taxa de ocupação do lote a ser utilizada; e $\mathrm{C}=$ coeficiente de aproveitamento máximo do lote (específico para cada Zona).
} 
Granville Hardwick SEWELL defende o "controle ambiental”, apresentando-o como sendo: "a arte e a ciência de controlar as atividades humanas que afetem ou degradem o ambiente natural ... o termo é aqui interpretado como um esforço consciente e sistemático feito pelas pessoas que agem em conjunto para produzir um meio ambiente esteticamente agradável, economicamente viável e fisicamente sadio." Todas as pessoas em atividade praticam um certo grau de controle, que pode deteriorar o ambiente, como o campista que joga lixo no lago até os milhões de motoristas que diariamente despejam toneladas de gases tóxicos e poluentes.

A água e o solo têm grande importância nos estudos ecológicos e ambientais, mas o principal meio ambiente dos seres humanos é o ar, pois vivemos imersos na atmosfera. Assim, estudar a qualidade do meio ambiente humano implica em examinar predominantemente os problemas relacionados com o ar, os quais podem ser agrupados em duas abordagens: a) Higiene atmosférica, que trata o ar como alimento ou matéria-prima, abrangendo todos os tipos de poluição e contaminação, e b) Climática, que examina a adequação do ar enquanto envolvente, considerando as variações causadas pela insolação, pelos ventos e pela umidade sobre as sensações térmicas.

No caso dos Espaços Livres em Áreas Verticalizadas, percebe-se a ocorrência de várias alterações do entorno que diminuem a satisfação ambiental das pessoas e, portanto, também reduzem a sua sensação de qualidade.
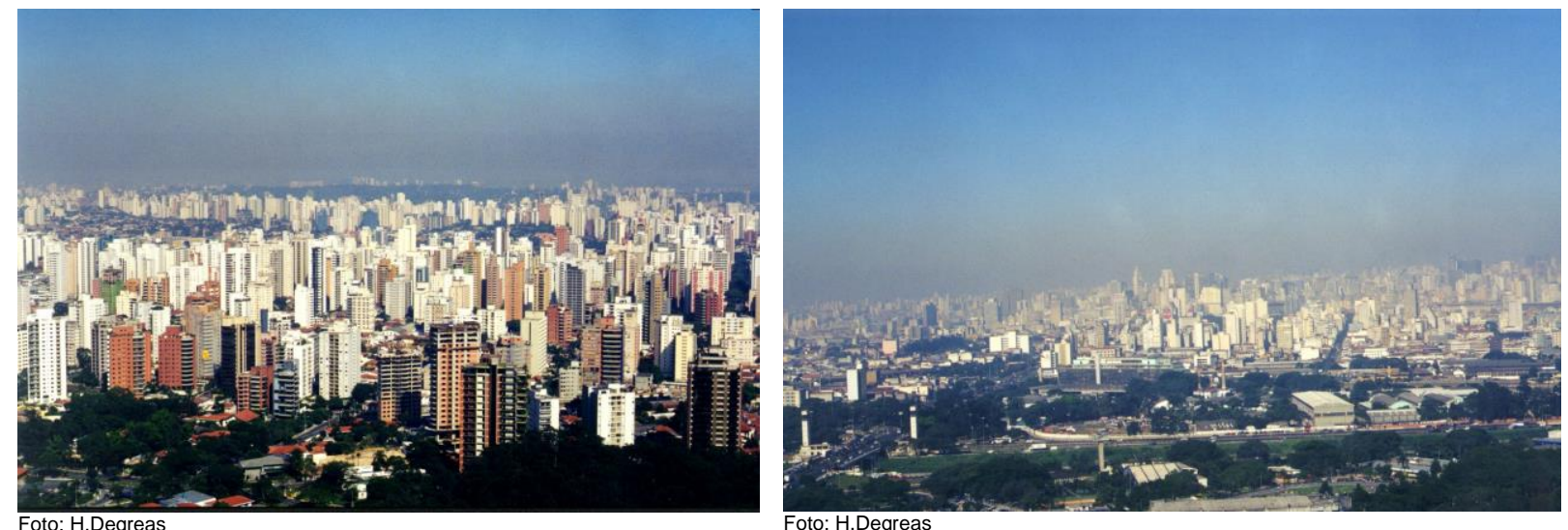

Figura 1-8: Freqüentemente, a Grande São Paulo é envolvida por uma camada de poluição.

Os problemas de Poluição abrangem a cidade como um todo, afetando também os Espaços Livres, pois em alguns casos, a implantação e a volumetria das edificações acentuam a concentração de poeiras, gases, cheiros e ruídos.

\footnotetext{
9 SEWELL, Granville Hardwick (1978 p.1).
} 

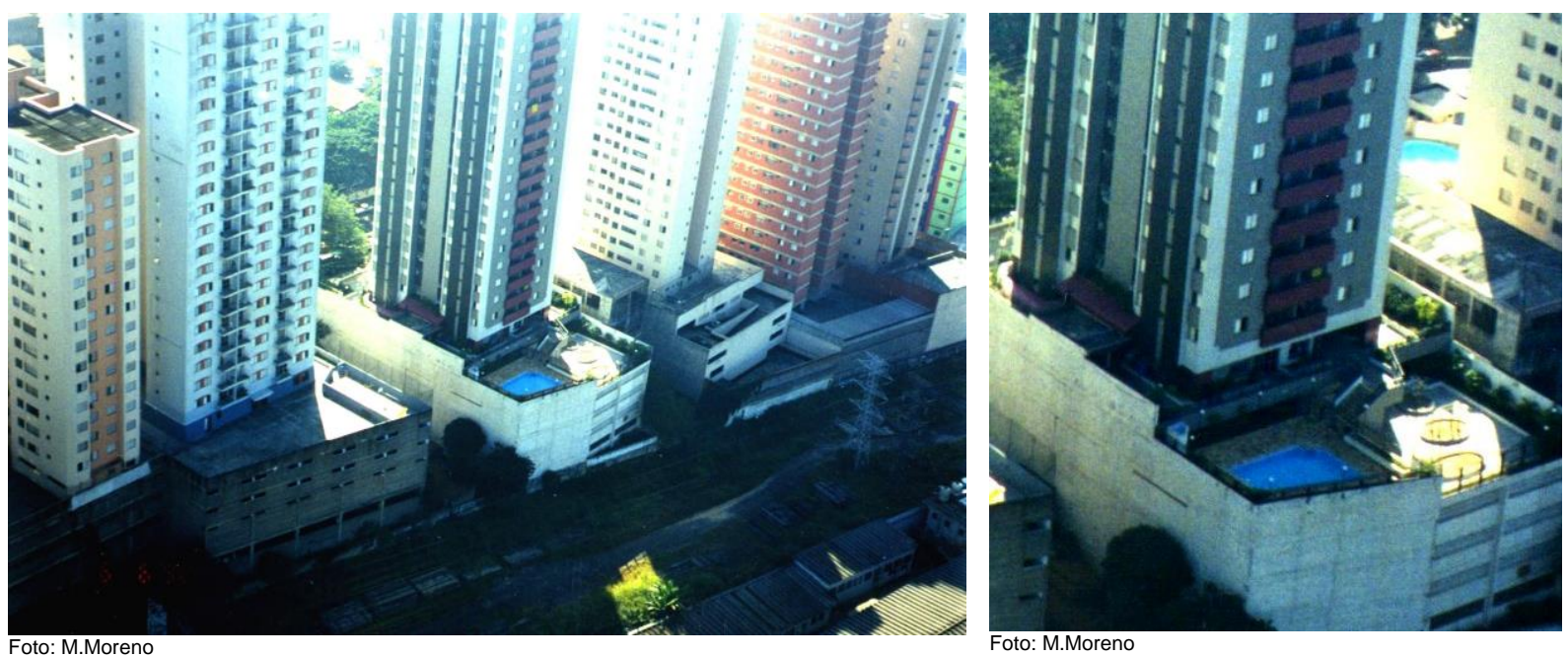

Figura 1-9: A implantação inadequada da edificação piora as condições microclimáticas. Por exemplo, o edifício em primeiro plano sombreando a piscina; no detalhe ampliado, pode-se observar, ao fundo à direita, que a piscina do outro edifício tem insolação adequada por estar voltada para a face norte.

As alterações Microclimáticas devidas à grande quantidade de edificações altas aumentam as áreas constantemente sombreadas, que nunca recebem Sol, ou se recebem, é por momentos muito curtos ou em períodos inadequados, como por exemplo, no auge do Verão, quando não seria necessário. Os ventos também são afetados. Em alguns casos, as edificações de grande porte obstruem a ventilação, gerando espaços abafados e em outras situações, a forma e a disposição dos prédios aceleram os ventos, aumentando o desconforto e a sensação de frio nas áreas sombreadas, principalmente no Inverno.

\subsection{Estudos Precedentes}

A maioria das pesquisas visando, por exemplo: Mestrados e Doutorados, na área da qualidade ambiental, tem focalizado o desempenho dos espaços internos das edificações ou quando examinam as variáveis ambientais externas a finalidade é obter subsídios para adequar a ambiência interna das construções ${ }^{10}$.

Os trabalhos que se detêm na análise dos problemas da qualidade dos espaços abertos sob o ponto de vista técnico-ambiental, visando fornecer parâmetros para projetos urbanisticos, são poucos. Dentre os principais, podemos destacar: a tese de

\footnotetext{
10 Entre os trabalhos voltados para a qualidade dos ambientes internos, inclui-se nossa dissertação de mestrado apresentada à FAU USP: MORENO, Manuel - Habitação Verticalizada, Habitabilidade e Desenho Urbano: o caso do conjunto habitacional Santa Cruz em São Paulo, Dissertação de Mestrado, São Paulo, FAU USP, 1991, que procurou analisar o conforto térmico em apartamentos a partir das características de implantação das edificações no tecido urbano.
} 
doutorado de Marta ROMERO ${ }^{11}$; a Cartilha Urbanística do Clima: indicações para Plano Diretor, elaborada pelo Ministério da Economia de Baden-Württemberg ${ }^{12}$; a tese de doutorado de Ester HIGUERAS ${ }^{13}$; e o livro Ambiência Urbana de Lucia MASCARÓ ${ }^{14}$. Todos eles trazem importantes contribuições para melhorar o ambiente urbano, porém, nenhum deles focaliza especificamente a qualidade ambiental nos espaços livres que permeiam as áreas verticalizadas.

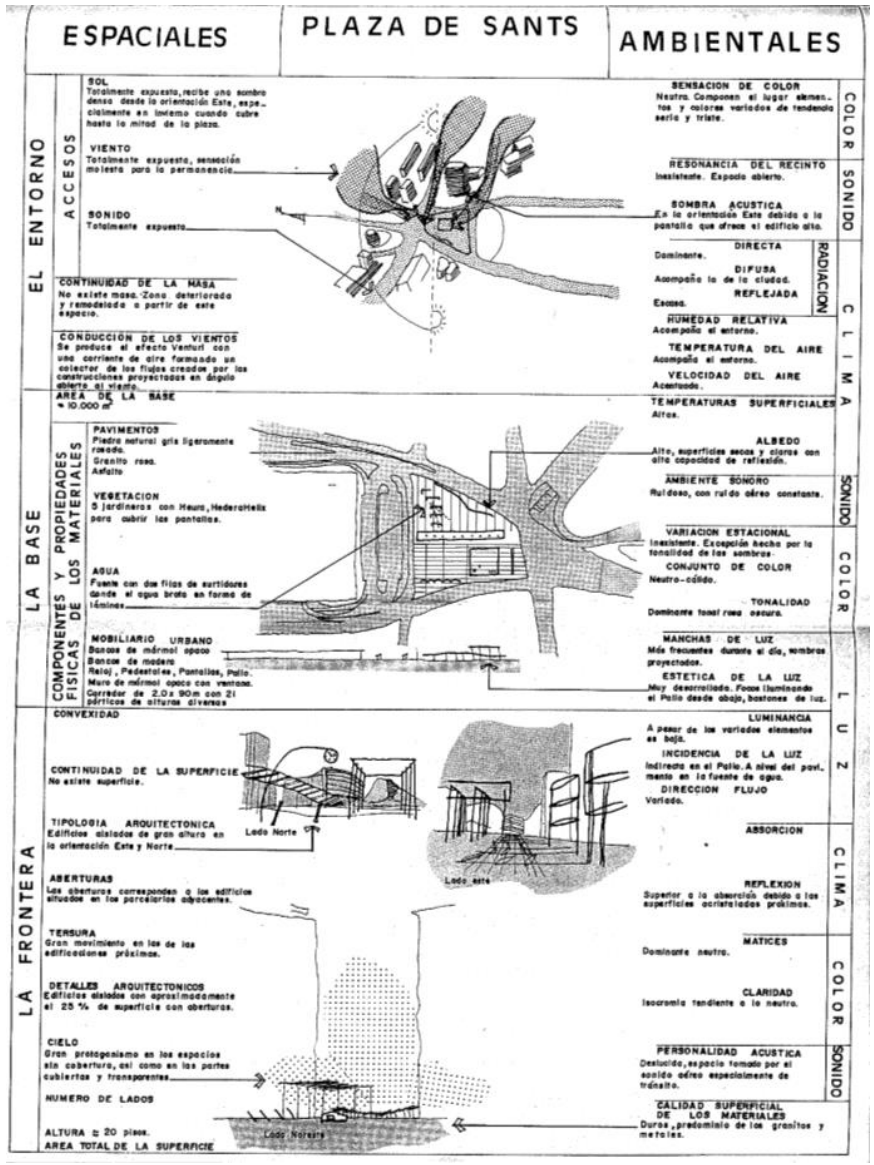

Figura 1-10: Ficha Bioclimática de Marta Romero.
ROMERO, por exemplo, desenvolveu planilhas de análise de Espaços Públicos, denominadas "Fichas Bioclimáticas", que sintetizam as características Espaciais (do Entorno, da Base e do Perímetro) e alguns aspectos Ambientais (Luz, Cor, Sons e Clima). Trata-se de uma análise descritiva qualitativa, que reforça a necessidade de uma visão mais ampla e abrangente dos problemas ambientais, induz a uma análise intuitiva, utilizando os órgãos dos sentidos, entretanto, não efetua medições físicas dos elementos examinados que possibilitem estabelecer valores comparativos. É um instrumento que ajuda a analisar o entorno e desenvolver a percepção e 0 senso crítico do enfoque ambiental.

\footnotetext{
11 ROMERO, Marta Adriana Bustos; Arquitectura Bioclimática de los Espacios Públicos, tese de doutorado defendida na Universidade Politécnica de Cataluña, Barcelona, 1993.

12 MINISTÉRIO DA ECONOMIA DE BADEN-WÜRTTEMBERG; Cartilha Urbanística do Clima, indicações para Plano Diretor, seqüência 2, Stuttgard, 1995, (tradução de Francisco de Assis Gonçalves da Silva, UFPb, João Pessoa, 1998).

13 HIGUERAS, Ester; Urbanismo Bioclimático - critérios medioambientales en la ordenación de assentamientos, tese de doutorado defendida na Escuela Técnica Superior de Arquitectura, Madrid, 1997.

${ }^{14}$ MASCARÓ, Lucia Raffo de; Ambiência Urbana, Porto Alegre, Ed. Sagra-Luzzatto, 1996.
} 
O Ministério da Economia de Baden-Württemberg, na Cartilha Urbanística do Clima, parte do princípio de que a superfície da Terra, as povoações e o espaço vital estão expostos às correntes de energia que partem do Sol, formando a dinâmica da Atmosfera, que com relação a seus aspectos em prazo mais longo designamos Clima. O Ar, o Clima e o Sol são os fundamentos básicos naturais da vida e, portanto, estão em conexão com planejamentos urbanísticos. A Cartilha trabalha com mapas de Clima (Meteorológicos e Climáticos) e mapas da Higiene do $\mathrm{Ar}$ (Termografia Infravermelha e Carga Poluidora do Ar); chega a propor planos para construções voltadas ao consumo consciente de energia e o uso de túnel aerodinâmico como recurso para o planejamento urbano, tanto no aspecto da dispersão de poluentes como no conforto dos pedestres em relação ao vento.

\begin{tabular}{|c|c|c|c|c|c|c|}
\hline \multirow{2}{*}{\multicolumn{2}{|c|}{$\begin{array}{c}\text { Critérios de Otimização } \\
\text { Ambiental }\end{array}$}} & \multicolumn{5}{|c|}{ Variáveis do Meio Natural } \\
\hline & & Sol & Vegetação & Vento & Água & Geomorfologia \\
\hline \multirow{5}{*}{ 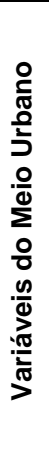 } & Rede Viária & $\begin{array}{l}\text { Orientação } \\
\text { Forma }\end{array}$ & & $\begin{array}{l}\text { Orientação } \\
\text { Forma }\end{array}$ & Microclima externo & $\begin{array}{l}\text { Suporte } \\
\text { Solo } \\
\text { Topografia }\end{array}$ \\
\hline & Espaços Livres & $\begin{array}{l}\text { Orientação } \\
\text { Forma }\end{array}$ & & $\begin{array}{l}\text { Orientação } \\
\text { Forma }\end{array}$ & & $\begin{array}{l}\text { Suporte } \\
\text { Solo }\end{array}$ \\
\hline & $\begin{array}{l}\text { Condições das } \\
\text { Quadras }\end{array}$ & $\begin{array}{l}\text { Orientação } \\
\text { Geometria } \\
\text { Densidade }\end{array}$ & & $\begin{array}{l}\text { Orientação } \\
\text { Geometria } \\
\text { Densidade }\end{array}$ & & \\
\hline & $\begin{array}{l}\text { Condições dos } \\
\text { Lotes }\end{array}$ & $\begin{array}{l}\text { Geometria Alturas } \\
\text { Ocupação } \\
\text { Edificabilidade }\end{array}$ & & $\begin{array}{l}\text { Geometria } \\
\text { Alturas } \\
\text { Edificabilidade }\end{array}$ & & \\
\hline & $\begin{array}{l}\text { Condições de } \\
\text { Edificabilidade }\end{array}$ & $\begin{array}{l}\text { Controle Solar } \\
\text { Condicionamento } \\
\text { Passivo }\end{array}$ & & $\begin{array}{l}\text { Ventilação } \\
\text { Aberturas }\end{array}$ & Microclima interno & \\
\hline
\end{tabular}

Quadro 1-2: Matriz de interação entre o meio natural e o meio urbano. (fonte: HIGUERAS, 1997; tradução:M.MORENO; obs: a coluna Vegetação aparece em branco).

HIGUERAS estudou as relações do meio ambiente natural com o meio urbano determinando e isolando as variáveis envolvidas, a fim de entender a filosofia do urbanismo bioclimático. Cita cinqüenta exemplos de planos e projetos, espalhados pelo mundo, que visam reduzir a deterioração ambiental, cada um deles abordando alguns aspectos da problemática ambiental. Os tópicos dos assuntos tratados nos cinqüenta trabalhos citados seguem a seguinte distribuição porcentual: $92 \%$ tratam da Integração com o Entorno Natural, 82\% versam sobre Projeto Urbano, 58\% buscam a Reabilitação Arquitetônica, 46\% enfocam o Tratamento de Resíduos Sólidos, 44\% procuram ordenar a Atividade Econômica, 42\% são propostas sobre Gestão da Água, 40\% atentam para a Economia de Energia e $40 \%$ enfrentam os Problemas de Acessibilidade. 
A Matriz de interação entre o meio natural e o meio urbano, apresentada pela autora, é um ponto de vista que deve ser retomado e experimentado. ${ }^{15}$

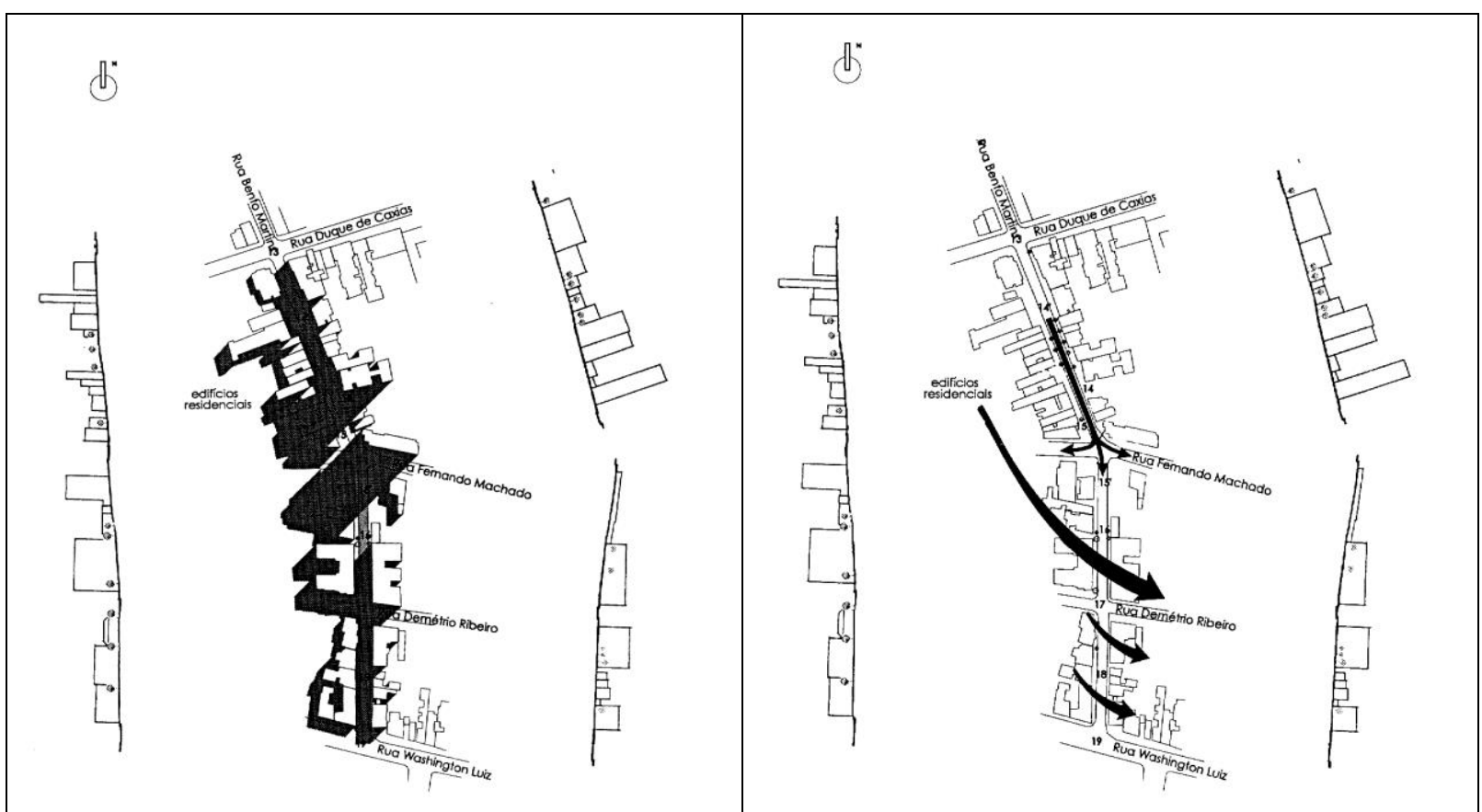

Figura 1-11: Estudos de Insolação e Ventos, para detectar a ambiência urbana. (fonte: MASCARÓ)

MASCARÓ analisa diversas ruas e praças de Porto Alegre, relacionando suas Morfologias (apresentadas por planta, elevações e perspectiva) com o Clima (examinado através da insolação, da umidade do ar, dos ventos e do fator de céu visível). O uso da esfera espelhada, lâmpada tipo Baloon, para fotografar e medir o fator de céu visível é o principal destaque, dentre os instrumentos utilizados. Este equipamento, que é uma adaptação da "câmara de Robin Hill"16, tem o mérito de facilitar e simplificar o estudo da porção de céu visível e a área obstruída por edificações e outros obstáculos. Utilizando-se os diagramas adequados, que segundo nossos experimentos são as projeções eqüidistantes ${ }^{17}$, pode-se determinar, com um deles a porcentagem de céu visível e com outro as estações e horários em que a radiação do Sol incidirá no local estudado.

\footnotetext{
15 Embora no quinto capítulo, HIGUERAS comente uma aplicação prática em Madrid, em nenhum momento o trabalho mostra levantamentos de campo. Trata-se de um trabalho teórico, em que o Manual de Urbanismo Bioclimático consiste em uma lista de dezoito lembretes, conselhos e recomendações de critérios para a otimização ambiental.

16 OLGYAY (1998, P.78) utiliza e apresenta a câmara de Robin Hill, inclusive com várias fotos tiradas do centro da pista de patinação do Rockefeller Center em Nova York.

17 ASSIS, Eleonora (2000, p.148) também realizou experimentos para verificar qual é a projeção obtida ao se fotografar uma superfície esférica espelhada e confirmou que é a projeção eqüidistante.
} 
Todos estes estudos trazem contribuições úteis que merecem ser retomadas e, na medida do possível, aprofundadas. Nossas concepções convergem em diversos aspectos com as apresentadas nos trabalhos citados. São elas:

a) O Meio Urbano não substituiu o Meio Natural, estes não são excludentes; a nosso ver o Meio Urbano está imerso no Meio Natural, que também é o enfoque defendido por HIGUERAS ${ }^{\text {(op. cit.13) }}$ e SPIRN $^{18}$

b) O Arquiteto deve ter uma visão mais abrangente das relações de suas intervenções com o entorno, um enfoque Ambiental que extrapole os contextos dos confortos: térmico, acústico e lumínico. O funcionamento dos Ciclos biogeoquímicos, que permeiam Ar, Água, Solo, Fauna e Flora, devem ser preservados sejam quais forem as Intervenções, para manter a Sustentabilidade da natureza e da própria Vida Humana.

c) Os Ecossistemas e os Biociclos funcionam impelidos por Fluxos de Energia vindos do Sol, que por sua vez transportam Informações e impulsionam Fluxos de Materiais. Obter Qualidade Ambiental é adequar os Fluxos de Energias, Informações e Materiais, aos Biociclos e à nossa Perceptibilidade, que abrange todos os órgãos dos sentidos e não só a Visão, a Audição e o Tato Térmico, mas também, Olfato, Tato Textura, Equilíbrio, Cinestesia e Instintos.

Embora o Arquiteto tenha uma formação abrangente e interdisciplinar, precisamos desenvolver procedimentos de percepção e análise que sejam além de rápidos, abrangentes e objetivos; e que inclusive ajudem a aprimorar a percepção do profissional. Nesse aspecto nos alinhamos com a idéia de elaborar planilhas ou roteiros como as Fichas Bioclimáticas de ROMERO que guiem as observações e as etapas das análises.

d) Os órgãos dos sentidos são instrumentos de medida muito importantes, à disposição dos seres humanos em geral, e do arquiteto em particular, que necessitam ser treinados e aperfeiçoados, mas que podem e devem contar com ajuda de alguns instrumentos de medida para quantificar as percepções. Nesse aspecto, acreditamos que os Arquitetos têm a obrigação de se familiarizar com: higrômetros, luxímetros, anemômetros, decibelímetros, relógios de sol (aparelhos que atualmente são pouco onerosos, em virtude do barateamento da eletrônica), como se podem ver no capítulo cinco, de modo a precisar melhor suas ações

18 SPIRN, Anne Whiston - O Jardim de Granito, São Paulo, Edusp,1995. 
projetuais. Além disso, pode adaptar e utilizar equipamentos simples como fizemos com a esfera espelhada, também descrita em MASCARÓ ${ }^{\text {(op. cit.) }}$ e ASSIS $^{\text {(op. cit.) }}$

e) Estamos convencidos de que a noção do Ecossistema como um todo deve estar sempre presente, porém, ao considerar a qualidade ambiental na escala da vizinhança tem-se que o Ar é o Meio Ambiente do ser humano, comparecendo a água, o solo, a fauna e a flora como coadjuvantes e, portanto, o Ar deve ser o foco principal das análises. Por isso centramos na Higiene Atmosférica (poluições e contaminações do ar) e no Microclima (insolação, ventos, umidade e temperaturas), os estudos de qualidade ambiental, (como também é proposto pelo Ministério da Economia de Baden-Württemberg na Cartilha Urbanística do Clima).

\subsection{Sistemas de Relações formam os Contextos da Realidade}

A primeira idéia que temos da realidade é que ela é física, material. A Natureza é composta de ar, água, solo, energias, vegetais e animais; é nela que ocorrem as intervenções Arquitetônicas e Urbanísticas, que são as construções e os assentamentos.

A realidade não é só a parte física, material da natureza; nela também circulam energias que contém informações e impulsionam as matérias-primas.

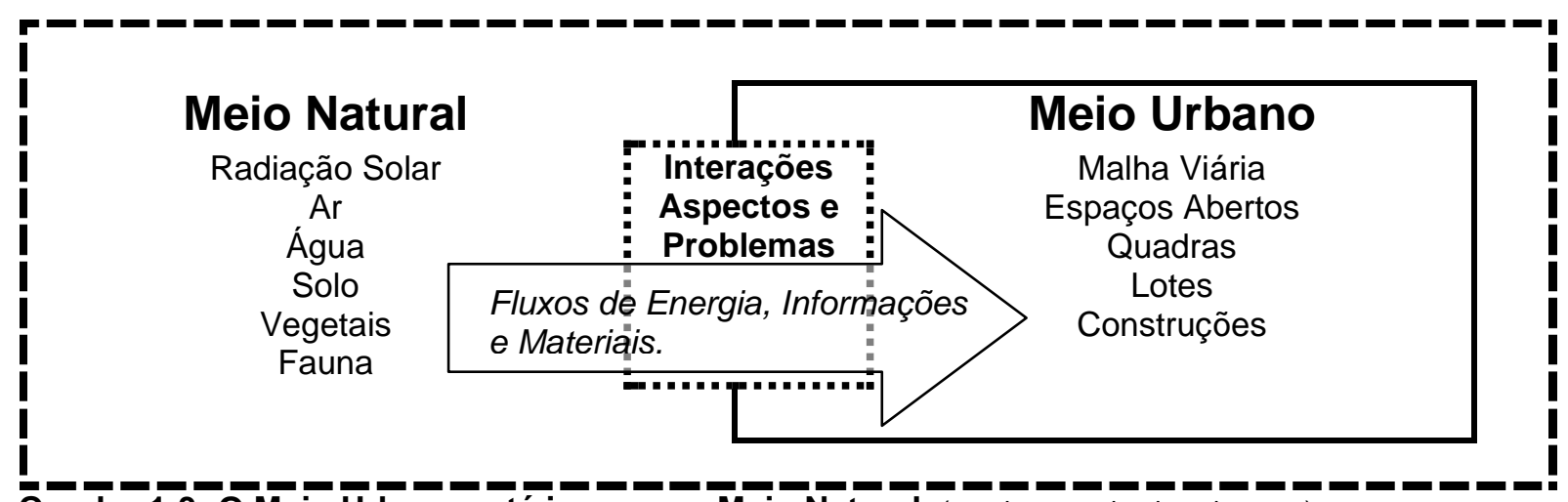

Quadro 1-3: O Meio Ürbano está imerso no Meio Natural. (quadro organizado pelo autor)

Os elementos que compõem a realidade, formam emaranhados de relações, muitos deles bastante imponderáveis e subjetivos, como são todos os Sistemas de Relações: culturais, psicológicas, sociais, ambientais, econômicas, etc... .

A produção da Arquitetura e do Urbanismo ocorre em meio a esses Sistemas, com eles interage, deles sofre influências e sobre eles influi; independentemente do Arquiteto estar ciente e apto ou não para lidar com todos eles. 


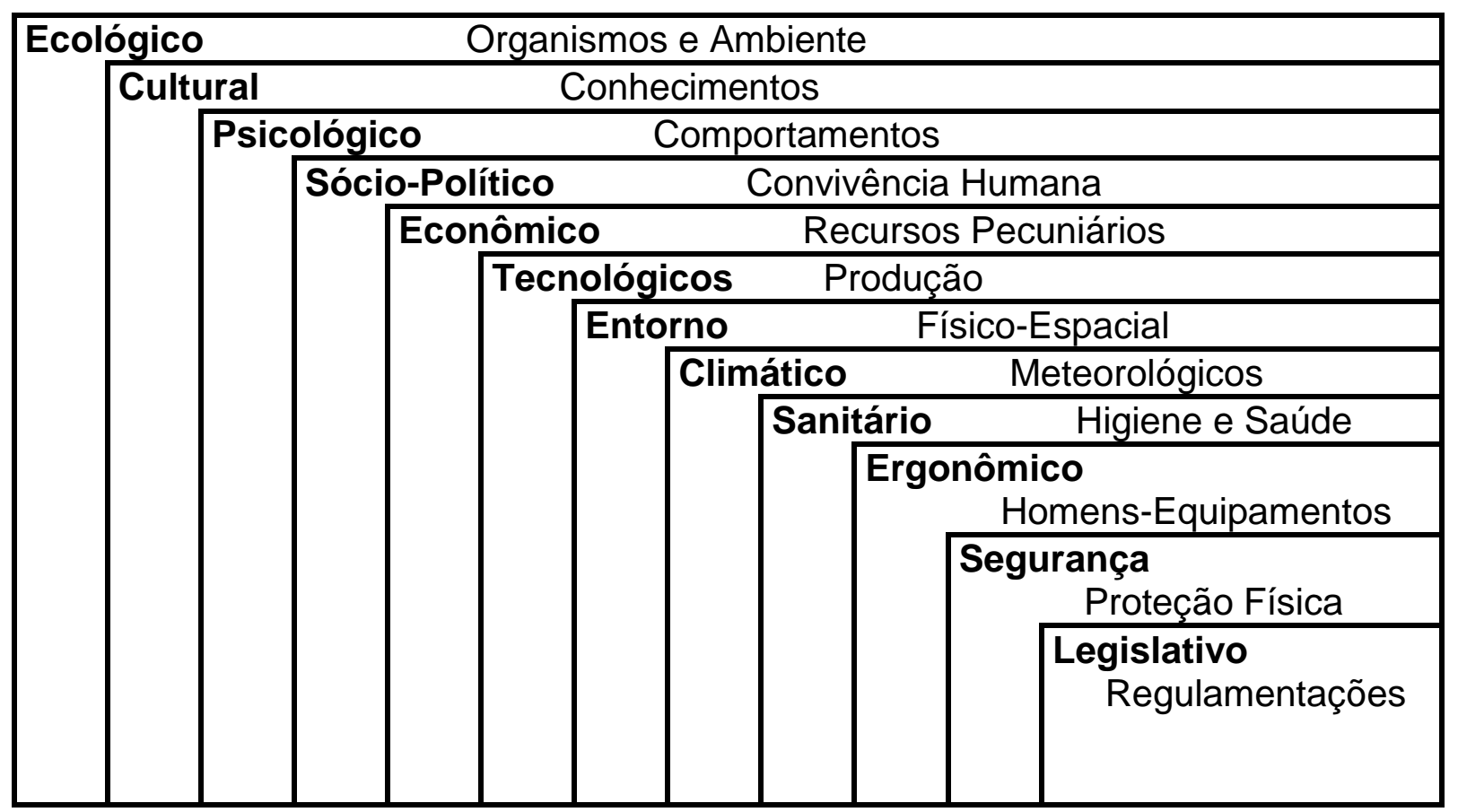

Quadro 1-4: Sistemas de Relações nos quais a Arquitetura e o Urbanismo interagem. (quadro organizado pelo autor)

Certamente, por mais atento que seja o profissional, alguns dos aspectos dos Sistemas de Relações Ihe passarão desapercebidos. É comum o Arquiteto ser criticado por uma ou mais omissões. Críticas como: o Memorial da América Latina nega seu entorno; a reurbanização do Brás passou longe das necessidades culturais e comportamentais da população de raízes italianas e nordestinas originais; o Plano Piloto da Capital Federal não previu a integração da população que a construiu; ou o prédio da escola tem ateliês muito frios no inverno, quentes no verão e barulhentos em dias de chuva forte; etc....

É necessário entender que, consciente ou inconscientemente, adequada ou inadequadamente, toda vez que realizamos uma obra de Arquitetura ou de Urbanismo originam-se interações e ou interferências em vários Sistemas de Relações.

Uma forma de perceber a realidade, na qual a Arquitetura e o Urbanismo se inserem, atuam e interagem, é analisar cada um desses Sistemas, tendo em mente que cada um deles é um enfoque, um ângulo de aproximação, um ponto de vista, uma percepção da realidade, um dos contextos da realidade. 


\subsection{Percepção: a Realidade em nossa Mente}

Todas as substâncias emitem e ou refletem Energias, tais como: Térmica, Luminosa, Eletromagnética, Química, Mecânica, etc... . As combinações, características e intensidades das várias energias transportam Informações. Essas energias ao atingir os órgãos dos sentidos, geram em nossa Mente, Sensações. A Percepção da Realidade ocorre pela filtragem e interpretação mental das Sensações recebidas, as quais são comparadas com o repertório de informações da pessoa. $O$ resultado é o conhecimento, a Cognição, que é composta por Imagens Mentais Virtuais associadas a significados.

São muitas as variáveis envolvidas no processo de Percepção, assim como a experiência de vida é característica de cada um de nós, os filtros mentais também são peculiares a cada pessoa. Como são os filtros mentais que determinam o que fica ou não retido em nossas mentes, a Cognição da Realidade é específica de cada pessoa, não sendo exatamente a mesma para todos os indivíduos. Como ilustração, podemos citar que o tempo de convivência com um Ambiente, é uma das variáveis que afeta a percepção; isto é, a Imagem Mental Virtual, que temos de uma Cidade vai se modificando de acordo com o tempo de convívio. Como cada pessoa tem vivências diferentes com o meio físico, no tempo e no espaço, as Cognições também resultam diferentes.

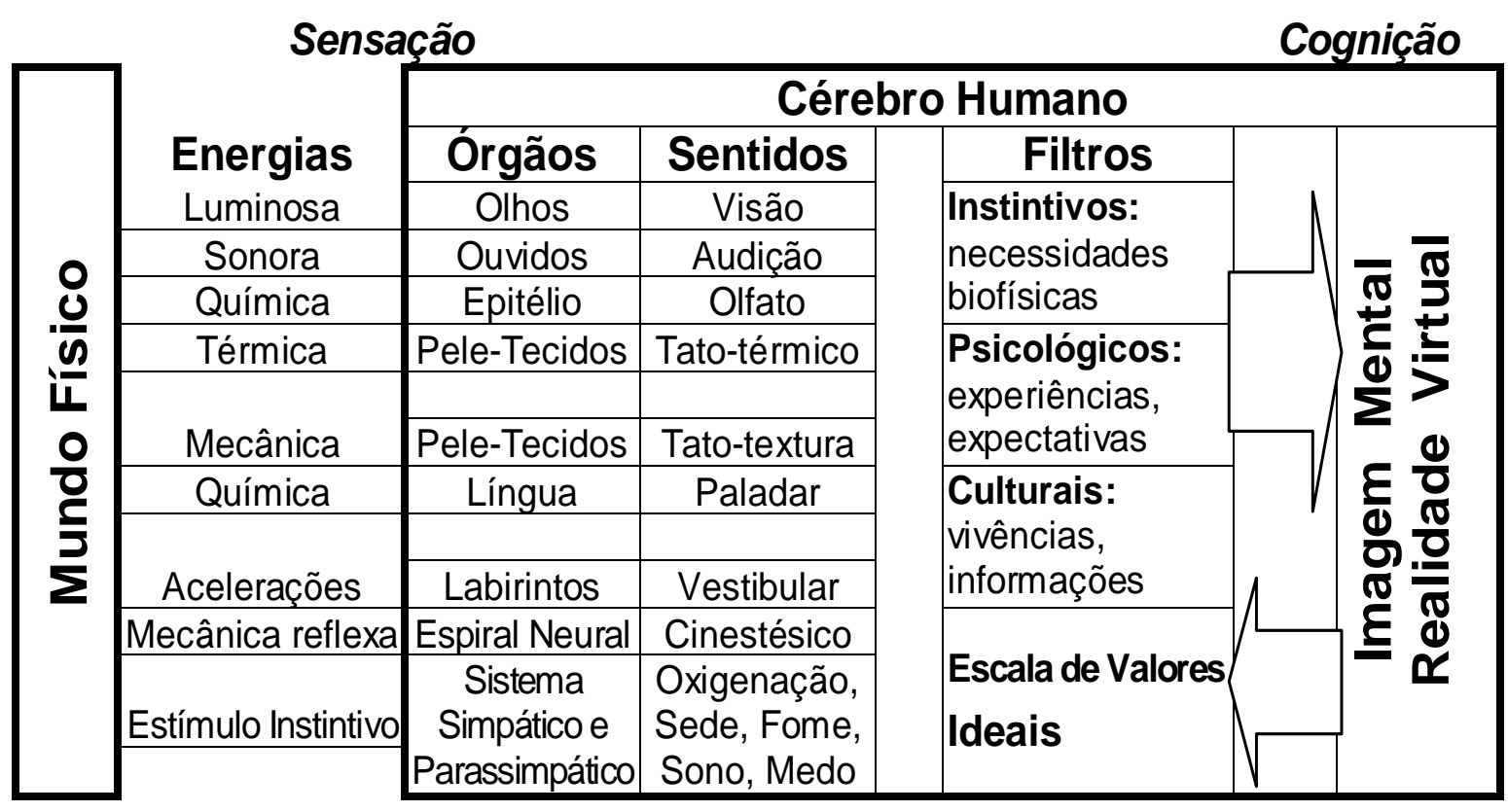

Quadro 1-5: Processo de Percepção: a formação da Realidade Virtual na Mente Humana. (quadro organizado pelo autor) 
O quadro esquematiza o funcionamento da Percepção Humana, destacando-se a Sensação, que é o estímulo físico sensorial e a Cognição, que é a imagem mental virtual que fica retida em nossa mente.

Os Filtros mentais subdividem-se, basicamente, em três categorias: Instintivos, Psicológicos e Culturais.

Os filtros Instintivos correspondem às informações genéticas que trazemos ao nascer, tem a ver com as necessidades biofísicas, tais como as de: oxigênio, água, alimento, sono, proteção, perpetuação da espécie, etc... . Normalmente, como o nome diz, implicam em reações instintivas, isto é, reações reflexas, automáticas.

Os filtros Psicológicos também geram reações reflexas automáticas, porém, ao contrário dos instintos, são formados por expectativas, condicionamentos, e experiências vivenciadas. Quando as ocorrências se repetem várias vezes da mesma maneira, psicologicamente acreditamos que os eventos se repetirão sempre assim, cria-se um condicionamento e nossas reações passam a ser reflexos condicionados.

Os filtros Culturais são as informações, os conhecimentos, transmitidos e acumulados ao longo das gerações. Eles criam as Escalas de Valores, as Intuições e os Ideais, diferenciados em cada pessoa; conseqüentemente, os efeitos no processo perceptivo também são diferenciados. A Escala de Valores é a hierarquização das cognições. Cada informação assimilada seja consciente ou inconscientemente, é comparada com a Escala de Valores, resultando um préjulgamento, uma pré-conceituação, uma Intuição. As Intuições, não são conhecimentos, são aproximações dos conhecimentos e chegam a nortear comportamentos e ações concretas. Os Ideais são concepções das mais altas aspirações das pessoas, produzidas a partir da escala de valores; poderíamos considerá-los filtros racionais, influem intensamente na conduta e no estilo de vida das pessoas.

Em termos Ambientais, Arquitetônicos ou Urbanísticos, nossos Ideais são os referenciais a partir dos quais emitimos julgamentos de valor, conceitos qualitativos, significados. Dependendo do nível de satisfação que obtemos, do meio ambiente, ao comparar nossos Ideais e Valores com as Sensações captadas do entorno, formamos opiniões de Qualidade Ambiental. 
Sobre esses processos, Lívia de OLIVEIRA ${ }^{19}$ comenta Piaget “... a noção de espaço e sua representação não derivam simplesmente da percepção: é o sujeito, mediante a inteligência, que atribui significados aos objetos percebidos, enriquecendo e desenvolvendo a atividade perceptiva".

\subsection{Onfoque do Arquiteto}

Nenhum ser humano tem a capacidade de dominar todos os conhecimentos, nem 0 Arquiteto, mas é fundamental que este, como outros técnicos, esteja consciente de que suas obras podem contribuir para melhorar ou agravar os vários Sistemas de Relações, isto é, sua atuação profissional pode aprimorar ou degradar cada um dos vários Contextos da Realidade. O aprofundamento intelectual do Arquiteto deve ocorrer no sentido de entender como sua produção profissional, suas obras, se relacionam com os vários Sistemas e de que maneira ajudam a qualificar a realidade como um todo.

A formação do Arquiteto é interdisciplinar e ampliar essa base tem que ser uma busca contínua. A interdisciplinaridade é condição básica para o aprofundamento intelectual que possibilitará, cada vez mais, a aproximação de suas propostas com a manutenção e aprimoramento dos vários Contextos da Realidade.

\begin{tabular}{|c|c|c|}
\hline $\begin{array}{c}\text { Contextos da } \\
\text { Realidade }\end{array}$ & $\begin{array}{c}\text { Metas de } \\
\text { Aprimoramento da Qualidade: }\end{array}$ & $\begin{array}{c}\text { Lida com } \\
\text { Sistemas de Relações: }\end{array}$ \\
\hline Ecológico & Ambiental (existência biológica) & de Seres e Ambientes \\
\hline Cultural & De Vida & de Conhecimentos \\
\hline Psicológico & Do Equilíbrio Físico-Emocional & de Comportamentos \\
\hline Sócio-Político & Da Convivência & de Convívio Humano \\
\hline Econômico & Do Empreendimento e sua Viabilidade & de Recursos Pecuniários \\
\hline Tecnológico & Dos Meios de Produção & Construtivas \\
\hline Entorno Físico & De Integração ao Meio & Espaciais \\
\hline Climático & De Adaptabilidade Biofísica & Meteorológicas \\
\hline Sanitário & De Higiene e Salubridade & de Higiene e Saúde \\
\hline Ergonômico & Sensorial e Antropométrica & do Homem - Equipamento \\
\hline Segurança & Contra Acidentes e Vulnerabilidade & de Proteção Física \\
\hline Legislativo & Normativa & de Regulamentações \\
\hline
\end{tabular}

Quadro 1-6: Contextos da Realidade, Sistemas de Relações e as Metas de aprimoramento da Qualidade. (quadro organizado pelo autor)

Os Contextos da Realidade podem ser físicos, materiais, objetivos e, portanto, mensuráveis; podem também ser virtuais, imateriais, subjetivos e difíceis de

\footnotetext{
19 OLIVEIRA, Lívia - Percepção e Representação do Espaço Geográfico, in Percepção Ambiental: a experiência brasileira. São Paulo, Studio Nobel e Editora da UFSC, 1996. (p.188)
} 
quantificar e analisar. O quadro relaciona e hierarquiza os Contextos dos Sistemas de Relações da Realidade, independentemente de serem objetivos ou subjetivos, físicos ou virtuais. Usamos como critério, colocá-los em ordem de importância para a sobrevivência e manutenção da espécie humana.

A listagem, embora envolva amplas áreas do conhecimento humano, sempre estará incompleta, pois o conhecimento evolui e as descobertas, abrem outras perspectivas, novos enfoques, outros pontos de vista, novos contextos da realidade. A hierarquização abrange, dos contextos de maior importância e abrangência, até aqueles que estão envolvidos pelos anteriores. Esse critério não é rígido e dependendo da abordagem ou do empreendimento, a seqüência de importância pode ter outra ordem.

A Qualidade Ambiental permeia todos os Contextos da Realidade. Neste estudo, a qualidade dos Espaços Livres é discutida pelo ponto de vista das relações Ecológico - Ambientais balizadas pelas limitações Sensoriais da Percepção Humana, tendo como referência a influência que o Meio Urbano Verticalizado (espaços livres, quadras, lotes e edificações) tem sobre as variáveis ambientais do Meio Natural (radiação solar, ar, água, solo, vegetação e fauna).

\subsection{Intervenções Arquitetônicas e Urbanísticas na Qualidade Ambiental}

Evidentemente cada edificação, cada obra, cada intervenção urbana, interfere e modifica as características ambientais. Pode-se estabelecer duas categorias de efeitos de qualquer obra Arquitetônica em um contexto, em relação ao tempo e o espaço: a) conseqüências resultantes do conjunto de obras, no geral da cidade, a médio e longo prazo; b) implicações pontuais, locais, de imediato, em curto prazo.

\subsubsection{Múltiplas Intervenções ao longo de Décadas}

No primeiro caso, o vertiginoso crescimento da metrópole e seu adensamento com a verticalização, modificaram expressivamente as características ambientais, na segunda metade do século.

Por exemplo: São Paulo era conhecida como a "terra da garoa" por sua elevada umidade. Ao ter sido fortemente modificada física e morfologicamente, tem apresentado significativas alterações climáticas, registrando ultimamente, 
baixíssimos índices de umidade relativa do ar, nos meses de junho, julho e agosto. As garoas agora são raras, embora nos meses de verão continuem os altos índices de umidade e as chuvas torrenciais.

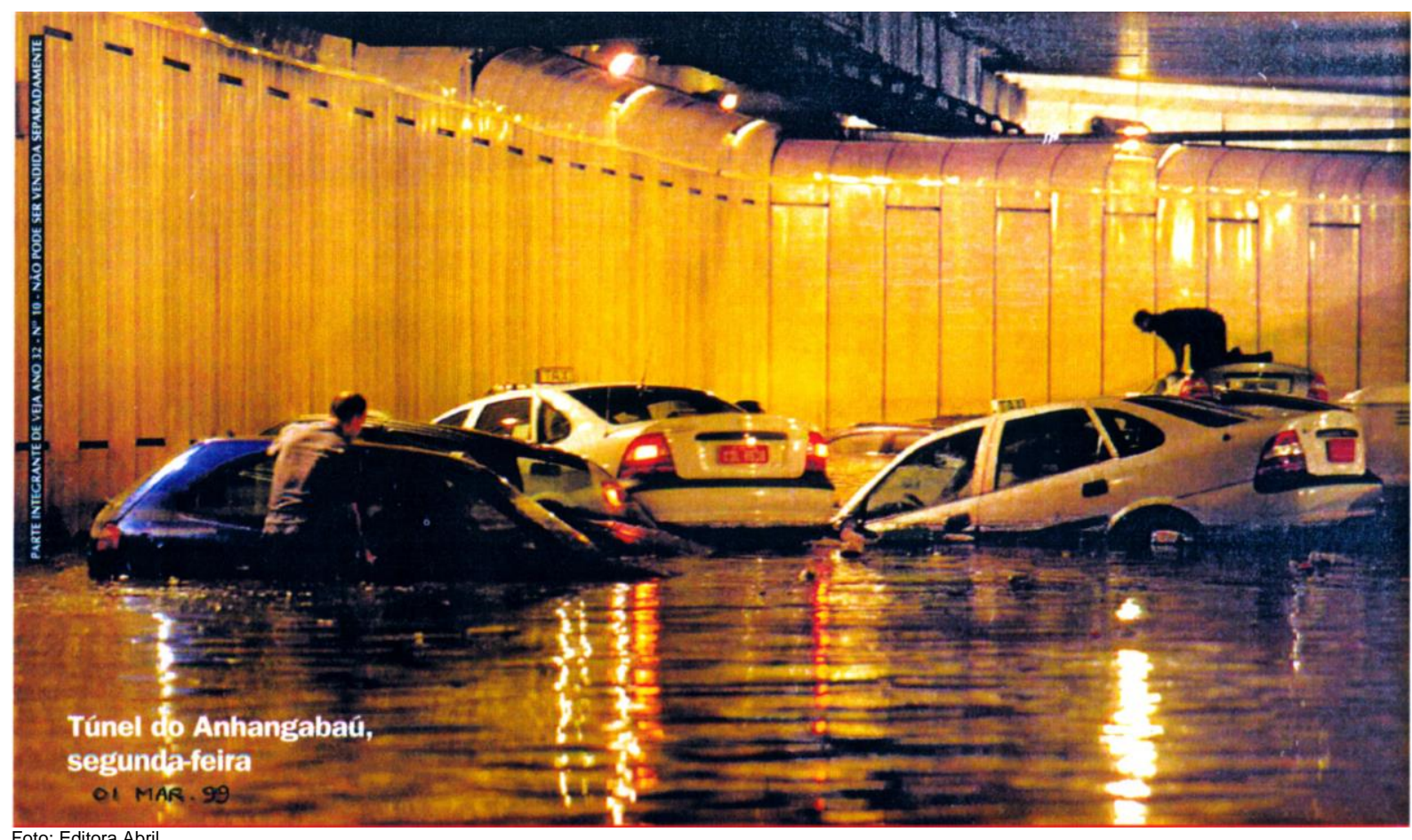

Figura 1-12: No verão, as Inundações são freqüentes.

O aumento da área urbanizada acentua as oscilações térmicas em dias secos, em função das características dos materiais componentes das superfícies. Assim, o ar de dia se aquece e a noite se esfria muito rapidamente, causando ilhas de calor e inversões térmicas, que agravam os problemas de poluição existente.

A urbanização e a impermeabilização do solo induzem e reforçam inundações, enxurradas e problemas de instabilidade de encostas. O crescimento da cidade, das atividades e da frota de veículos, aumenta a profusão e intensidade sonora.

Esses são alguns itens da qualidade ambiental afetada gradualmente ao longo do tempo pelas diversas intervenções, é muito difícil quantificar a responsabilidade de cada obra no conjunto dos problemas, mas com certeza qualificá-lo é um fato imediato.

Os seis quadros a seguir, apresentam os Aspectos e Problemas resultantes da ação do Ambiente Urbano sobre o Meio Natural na Macro-Escala, quando múltiplas intervenções afetam, em termos espaciais, vastas áreas e por muitas décadas em termos temporais; como por exemplo: as milhares de construções na 
Grande São Paulo ao longo de toda a segunda metade do século. São enfocados os componentes do Meio Natural: Ar, Água, Solo, Energia Solar, Flora e Fauna.

Os componentes Naturais, além de serem Meio Ambiente, sob certos aspectos também são Alimentos e Recursos Materiais.

\begin{tabular}{|c|c|c|c|}
\hline \multirow{2}{*}{\begin{tabular}{|l} 
Meio \\
Natural
\end{tabular}} & \multicolumn{3}{|c|}{ Implicações Urbanas } \\
\hline & Enquanto Meio Ambiente & Enquanto Alimento & $\begin{array}{c}\text { Como Recurso } \\
\text { Material }\end{array}$ \\
\hline $\mathrm{Ar}$ & $\begin{array}{l}\text { Iluminação e Insolação, alterações no } \\
\text { fator de céu visível, nas reflexões e } \\
\text { cores das superfícies. } \\
\text { Ruídos, por veículos, equipamentos e } \\
\text { vibrações. } \\
\text { Odores, resultantes de decomposições, } \\
\text { combustões ou reações químicas. } \\
\text { Térmicos (aquecimentos), provocados } \\
\text { por atividades urbanas, por reflexão das } \\
\text { superfícies e pelo calor específico dos } \\
\text { materiais, gerando llhas de Calor, } \\
\text { Domos de Poluição, Inversões } \\
\text { Térmicas. } \\
\text { Ventos podem ser acentuados ou } \\
\text { obstruídos, ter suas direções e } \\
\text { velocidades modificadas em função da } \\
\text { forma, volumetria e disposição das } \\
\text { construções. Em alguns casos, além de } \\
\text { causar desconforto, afetam o equilíbrio } \\
\text { das pessoas. }\end{array}$ & $\begin{array}{l}\text { Alimento, indispensável } \\
\text { para os humanos. É } \\
\text { necessário avaliar a } \\
\text { respirabilidade do ar. } \\
\text { Quantitativamente está } \\
\text { sempre disponível. } \\
\text { Qualitativamente piora } \\
\text { no inverno. }\end{array}$ & $\begin{array}{l}\text { Comburente, é o } \\
\text { fornecedor de oxigênio } \\
\text { para as combustões. } \\
\text { Poluição é causada } \\
\text { pelo uso intensivo e } \\
\text { descuidado. }\end{array}$ \\
\hline
\end{tabular}

Quadro 1-7: Interações do Ambiente Urbano com o Ar. (quadro organizado pelo autor)

\begin{tabular}{|c|l|l|l|}
\hline \multirow{2}{*}{$\begin{array}{l}\text { Neio } \\
\text { Natural }\end{array}$} & \multicolumn{3}{|c|}{ Implicações } \\
\cline { 2 - 4 } & \multicolumn{1}{|c|}{ Enquanto Meio Ambiente } & Enquanto Alimento & \multicolumn{1}{|c|}{$\begin{array}{l}\text { Como Recurso } \\
\text { Material }\end{array}$} \\
\hline Água & $\begin{array}{l}\text { Salubridade e Higiene dependem da } \\
\text { água. } \\
\text { Ilhas de Ar Frio são formadas pelos } \\
\text { Corpos d'água. } \\
\text { Umidade do Ar e Precipitações. } \\
\text { Enxurradas e Inundações, podem ser } \\
\text { causadas pela interação da água com } \\
\text { as características das superfícies e da } \\
\text { topografia. }\end{array}$ & $\begin{array}{l}\text { Alimento, indispensável } \\
\text { para os seres vivos. } \\
\text { Avaliar a potabilidade. } \\
\text { A degradação, dos } \\
\text { mananciais, causa } \\
\text { disponibilidade em } \\
\text { declínio. }\end{array}$ & $\begin{array}{l}\text { Solvente Universal, os } \\
\text { processos de produção } \\
\text { geralmente utilizam a } \\
\text { água. } \\
\text { Poluição e Desperdício } \\
\text { é necessário gerenciar o } \\
\text { uso da água. }\end{array}$ \\
\hline
\end{tabular}

Quadro 1-8: Interações do Ambiente Urbano com a Água. (quadro organizado pelo autor) 


\begin{tabular}{|c|l|l|l|}
\hline \multirow{2}{*}{$\begin{array}{c}\text { Meio } \\
\text { Natural }\end{array}$} & \multicolumn{1}{|c|}{ Implicações } & \multicolumn{1}{|c|}{ Urbanas } \\
\cline { 2 - 4 } Solo & $\begin{array}{l}\text { Enquanto Meio Ambiente } \\
\text { Bacias Hidrográfíficas e Topografia, } \\
\text { caracterizam o suporte através da } \\
\text { resistência do solo, da orientação de } \\
\text { vertentes, das declividades, da } \\
\text { emissividade e do albedo das } \\
\text { superfícies. } \\
\text { Depressões conduzem massas de ar } \\
\text { frio. } \\
\text { Permeabilidade e Drenagem afetam a } \\
\text { evaporação e a umidade do ar. } \\
\text { Desmoronamentos, Erosões e } \\
\text { Lixiviações são causados pela ação } \\
\text { das intempéries sobre o solo em geral, } \\
\text { plástico e erodível. } \\
\text { Lixo e Sujeira afetam o solo e podem } \\
\text { contaminar o subsolo e o lençol freático. } \\
\text { Desconforto Ergonômico causado } \\
\text { pela irregularidade das superfícies. }\end{array}$ & $\begin{array}{l}\text { Nutre e sustenta a } \\
\text { cadeia alimentar. }\end{array}$ & $\begin{array}{l}\text { Materiais de Construção, } \\
\text { vários são originários da } \\
\text { Litosfera, que é a fonte } \\
\text { de recursos naturais. } \\
\text { É vital que os materiais } \\
\text { sejam reciclados e } \\
\text { reutilizados. }\end{array}$ \\
\hline
\end{tabular}

Quadro 1-9: Interações do Ambiente Urbano com o Solo. (quadro organizado pelo autor)

\begin{tabular}{|c|c|c|c|}
\hline \multirow{2}{*}{$\begin{array}{l}\text { Meio } \\
\text { Natural }\end{array}$} & \multicolumn{3}{|c|}{ Implicações Urbanas } \\
\hline & Enquanto Meio Ambiente & Enquanto Alimento & $\begin{array}{c}\text { Como Recurso } \\
\text { Material }\end{array}$ \\
\hline \begin{tabular}{|c|} 
Energia \\
Solar
\end{tabular} & $\begin{array}{l}\text { Variações Climáticas (insolação, } \\
\text { ventos, umidades, precipitações e } \\
\text { temperaturas) são produzidas pela } \\
\text { radiação solar que se manifesta através } \\
\text { do ciclo hidrológico, da movimentação } \\
\text { atmosférica e do aquecimento das } \\
\text { superfícies. }\end{array}$ & $\begin{array}{l}\text { Alimento, ao possibilitar } \\
\text { a fotossíntese e } \\
\text { transformar-se em } \\
\text { energia química do } \\
\text { carboidrato. }\end{array}$ & $\begin{array}{l}\text { Fontes de energia, } \\
\text { todas são derivadas da } \\
\text { radiação solar. } \\
\text { Combustíveis fósseis } \\
\text { são esgotáveis e estão } \\
\text { degradando o ambiente. } \\
\text { É necessário gerenciar } \\
\text { o uso das fontes. }\end{array}$ \\
\hline
\end{tabular}

Quadro 1-10: Interações do Ambiente Urbano com a Energia Solar. (quadro organizado pelo autor)

\begin{tabular}{|c|l|l|l|}
\hline \multirow{2}{*}{$\begin{array}{l}\text { Neio } \\
\text { Natural }\end{array}$} & \multicolumn{3}{|c|}{ Implicações } \\
\cline { 2 - 4 } & \multicolumn{1}{|c|}{ Enquanto Meio Ambiente } & Enquanto Alimento & \multicolumn{1}{|c|}{$\begin{array}{l}\text { Como Recurso } \\
\text { Material }\end{array}$} \\
\hline Flora & $\begin{array}{l}\text { Massas arbóreas são ilhas de ar frio e } \\
\text { funcionam como filtros mecânicos ao } \\
\text { barrar parte do material particulado } \\
\text { transportado pelos ventos. } \\
\text { Árvores sombreiam as superfícies, } \\
\text { reduzindo a absorção de energia e a } \\
\text { emitância de calor. Arbustos barram os } \\
\text { ventos. } \\
\text { Vegetação Rasteira altera a emitância } \\
\text { das superfícies. }\end{array}$ & $\begin{array}{l}\text { Oxão gerados pela } \\
\text { fotossíntese. }\end{array}$ & $\begin{array}{l}\text { Materiais Renováveis, } \\
\text { como: Madeira, } \\
\text { Algodão, Vime, } \\
\text { Borracha. Desde que se } \\
\text { propiciem condições } \\
\text { adequadas, nunca } \\
\text { faltarão. }\end{array}$ \\
\hline
\end{tabular}

Quadro 1-11: Interações do Ambiente Urbano com a Flora. (quadro organizado pelo autor) 


\begin{tabular}{|c|c|c|c|}
\hline \multirow{2}{*}{\begin{tabular}{|l} 
Meio \\
Natural
\end{tabular}} & \multicolumn{3}{|c|}{ Implicações Urbanas } \\
\hline & Enquanto Meio Ambiente & Enquanto Alimento & $\begin{array}{c}\text { Como Recurso } \\
\text { Material }\end{array}$ \\
\hline Fauna & $\begin{array}{l}\text { Seres adaptados ao meio urbano } \\
\text { constituem populações maiores que as } \\
\text { humanas, são vetores de doenças, } \\
\text { podendo transmitir zoonoses, degradar } \\
\text { ou sujar o ambiente, é o caso de: } \\
\text { Cupins, Mosquitos, Formigas, Baratas, e } \\
\text { as fezes de Cães, Gatos, Pombos, } \\
\text { Ratos... }\end{array}$ & $\begin{array}{l}\text { Alimentos fornecem } \\
\text { importantes quantidades } \\
\text { de proteínas. }\end{array}$ & $\begin{array}{l}\text { Materiais Renováveis, } \\
\text { como: Couro, Lã, Seda. } \\
\text { Também nunca faltarão } \\
\text { desde que se propiciem } \\
\text { condições adequadas. }\end{array}$ \\
\hline
\end{tabular}

Quadro 1-12: Interações do Ambiente Urbano com a Fauna. (quadro organizado pelo autor)

Acreditamos que, além de ampliar a conscientização e instrumentalizar melhor os Arquitetos e Urbanistas, é indispensável que se estabeleçam diretrizes gerais de controle da qualidade ambiental, tais como Normas e Leis de Padrões Limitantes de Tolerabilidade Ambiental, com o envolvimento de toda a sociedade ${ }^{20}$.

Silvio Soares MACEDO ${ }^{21}$ explica a falta de envolvimento, da maior parte da população, em relação aos problemas ambientais: "A maioria da sociedade não compreende claramente as reações do ambiente às suas formas de atuação, não entendendo sua importância e extensão, e não tendo um significado imediato para o homem comum. A importância desses processos de transformação só é, então, percebido pela sociedade ainda que de um modo genérico, quando da obtenção de resultados evidentes, que a beneficiem ou prejudiquem, isto é, nos momentos de fartura ou de crise".

Entretanto, enquanto os habitantes da cidade continuarem a se sentir, visitantes de passagem, estranhos em sua própria urbe, enquanto acreditarem que aqui farão fortuna, mas viverão em outro lugar, enquanto não sentirem São Paulo como sua moradia, sua responsabilidade, sua propriedade, os vários instrumentos legais de controle ambiental e urbano disponíveis continuarão a ser ineficientes, porque para a maioria da população, esses são problemas dos outros, do governo, das empresas, de outras instâncias, não dele.

\footnotetext{
${ }^{20}$ SEWELL, Granville Hardwick,(1978, p.29) comenta, "Apesar das fraquezas, os Padrões continuarão a ser usados como expressões de objetivos para a qualidade do ambiente. Eles identificam metas que desejamos alcançar ou manter ao eliminar um poluente especial. Serão mal interpretados, e os políticos, juntamente com o público, expressarão suas frustrações. Os industriais e outros poluidores potenciais os atacarão por um lado, enquanto as vítimas da poluição os questionarão pelo outro. Contudo, mesmo este debate aberto sobre a qualidade do ambiente tem efeitos positivos, e o processo de fixação de um padrão pode tornar-se uma fase vital para conseguir qualidade ambiental dentro de um sistema político democrático." 21

MACEDO, Silvio Soares, (1993, p.7).
} 


\subsubsection{Intervenções Pontuais em Curto Prazo}

A constatação, a consciência, da influência de cada uma das inúmeras intervenções arquitetônicas ou urbanísticas nas características físicas do ambiente, ao longo das décadas, não é tão clara para a sociedade e nem para os profissionais Arquitetos e Urbanistas. Porém, no caso de ações pontuais, na escala local da vizinhança em termos espaciais e no curto prazo de poucos anos em termos temporais, é possível analisar e detectar, com maior clareza, as implicações de cada empreendimento na qualidade ambiental das áreas circunvizinhas.

O cerne deste trabalho prende-se à análise das intervenções pontuais, onde são maiores as possibilidades de avaliar e prever as influências da verticalização na qualidade ambiental dos espaços livres.

As variáveis do Meio Natural, Ar, Água, Solo, Radiação Solar, Vegetação e Fauna, são afetadas pelos seguintes elementos do Meio Urbano:

Estrutura Urbana: malha viária (sua orientação, declividade e dimensionamento, condicionam insolação e ventilação), adaptação topográfica (influi no perfil das vias, estabilidade do solo e drenagem), relações geométricas (dimensões de ruas e praças) e densidade de tráfego;

Espaços Livres: forma, localização, orientação, permeabilidade, vegetação;

Quadras: área delimitada por um conjunto de ruas (morfologicamente constituindose no negativo da estrutura viária), geometria, orientação e densidade edificada;

Lotes: geometria das parcelas, orientação e índices urbanísticos incidentes (taxa de ocupação e coeficiente de aproveitamento);

Edificações: volumetria, orientação, densidade, possibilidades de salubridade e compatibilidade de usos.

Em termos físicos, os problemas ligados à Energia Solar e ao Ar, que é o foco de nossa análise, por ser o meio ambiente específico em que os seres humanos estão imersos, podem ser agrupados sob duas referências: Higiene Ambiental e Clima.

A Higiene Ambiental envolve todos os problemas de poluição e contaminação atmosférica, tais como: Adequação Lumínica, Ruídos e Intensidades Sonoras, Odores e Gases, Materiais Particulados e Poluição Térmica.

O Clima abrange os problemas relativos ao conforto térmico, os quais dependem, no ser humano, da adaptabilidade, das atividades e da vestimenta e, em termos 
ambientais, é função de quatro variáveis inter-relacionadas: insolação, ventos, umidades e temperaturas.

Quanto aos outros componentes Ambientais, como a água, o solo, a vegetação e a fauna, eles têm importantes papéis como: recursos naturais, matérias-primas, suporte, alimento ou coadjuvantes, afetando a qualidade ambiental de maneira indireta. O meio ambiente fundamental dos seres humanos é a atmosfera, na qual vivemos imersos.

A Água enquanto Alimento é essencial, não podemos viver mais que alguns dias sem água. Os seres vivos estão altamente hidratados, pois $70 \%$ do corpo humano é água e a maioria das reações biológicas ocorre em meio aquoso.

Enquanto Recurso Natural, embora o planeta Terra tenha mais superfícies de água do que superfícies de terra, e o volume total seja da ordem de 1,4 bilhões de quilômetros cúbicos, a quantidade de água doce superficial em estado líquido é de apenas $0,8 \%$ do total, clamando por menos desperdícios e gerenciamento mais consciencioso desse recurso vital. Por exemplo, é inaceitável utilizar água potável tratada para dar descarga no vaso sanitário e carrear os esgotos; com certeza, para tal finalidade, poderíamos usar água menos nobre, já utilizada em outras atividades como a água do banho, da máquina de lavar roupas ou mesmo das chuvas.

No Meio Urbano, as Enxurradas e Inundações são as principais manifestações da pouca importância que a humanidade tem dado ao gerenciamento dos recursos hídricos. É indispensável detectar como eram os fluxos do ciclo hidrológico, em cada bacia, antes da implantação da impermeabilização causada pelo meio urbano e aplicar técnicas que restabeleçam a velocidade da onda de cheia original. Somos favoráveis que cada lote tenha, proporcionalmente à sua área, cisternas que acumulem as águas pluviais e as liberem lentamente, eliminando as repentinas ondas de cheias, causadoras das enxurradas e inundações.

O Solo fornece os nutrientes que sustentam as cadeias alimentares dos ecossistemas e é o suporte tanto do Meio Natural como do Meio Urbano. Enquanto Base Suporte, o solo, em função de sua estabilidade, declividade topográfica, resistência, permeabilidade e características da superfície, indica as possibilidades de utilização, sua capacidade de reter ou emitir calor, de acumular ou escoar água. Os principais problemas ambientais causados pela arquitetura e urbanismo em relação ao solo são: sua impermeabilização e deficiências de drenagem, que 
causam alagamentos e inundações, e as alterações das características dos materiais e cores das superfícies, que provocam a retenção de calor e contribuem para o aquecimento urbano.

A Vegetação é elemento fundamental na qualidade ambiental urbana, pois além de renovar parte do oxigênio atmosférico, também contribui para bloquear a circulação de poeiras e, ao sombrear as superfícies, diminui o calor absorvido amenizando o aquecimento urbano. No caso paulistano, o que mais surpreende é o contraste entre os níveis de vegetação dos vários bairros. Fotos aéreas mostram que em algumas áreas temos verdadeiras matas urbanas, enquanto em outras a vegetação inexiste.

A Fauna adaptada à vida urbana é muito significativa e numerosa, freqüentemente os noticiários destacam a destruição de componentes das construções e a derrubada de árvores causada por cupins; a proliferação de ratos que transmitem diversas doenças como a leptospirose; os mosquitos e a dengue; as fezes de cães, gatos e pombos causando muita sujeira; as formigas; os escorpiões; as baratas; as aranhas e vários outros animais que interferem na qualidade ambiental e com eles temos que estabelecer um equilíbrio adequado para conviver no mesmo habitat.

Parte-se do pressuposto, ainda não de consenso, ou conhecido, de que as intervenções arquitetônicas e urbanísticas modificam o ambiente natural, podendo melhorar ou piorar os padrões de qualidade dos espaços livres.

Para que esses padrões sejam alcançados e aprimorados, é necessário que o profissional reconheça, domine e corrija as implicações de suas obras nos espaços livres, quanto à iluminação, os ruídos, os odores, à insolação, os ventos, à umidade e às temperaturas.

Todas essas intervenções podem e devem ser dosadas, calibradas, controlando-se os fluxos de energia, trabalhando com o instrumental do Arquiteto: orientações, declividades, formas, volumes, superfícies, materiais, cores e vegetação. 



\section{Os Espaços Livres em Áreas Verticalizadas}

\subsection{Os Padrões de Verticalização na Cidade de São Paulo}

A verticalização é um dos principais fenômenos morfológicos que caracterizam a cidade de São Paulo na segunda metade do século XX. Podemos considerar que uma massa edificada é verticalizada quando as suas construções possuam mais de quatro andares ou altura total externa maior que quinze metros. Outra referência importante da verticalidade é saber que para vencer um desnível superior a 12 metros (quatro pavimentos), o Código de Obras e Edificações ${ }^{22}$ exige um elevador e para desníveis maiores que 24 metros, duas colunas de elevadores. Para nosso estudo, consideraremos edificações verticalizadas aquelas que tiverem mais de quatro pavimentos acima do nível do solo.

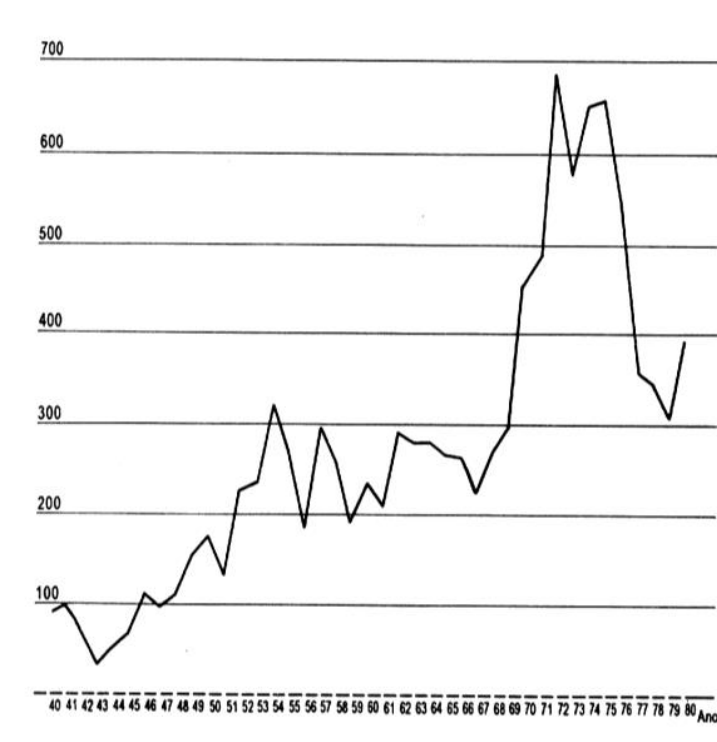

Gráfico 2-1: Número de edifícios, na cidade de São Paulo, com elevadores por ano, entre 1940 e 1980. (fonte: SOMEKH op.cit.24)

Alguns autores também relacionam $O$ elevador e a verticalização, SOUZA $^{23} \mathrm{em} A$ Identidade da Metrópole, comenta o código de edificações anterior, o de 1982, que também exige elevador para edifícios acima de quatro pavimentos e implicitamente os considera verticalizados. SOMEKH ${ }^{24}$ em $A$ (des) verticalização de São Paulo trabalha com o registro de elevadores da cidade de São Paulo e formula uma periodização da verticalização, desde 1940, considerando somente os edifícios com elevadores. Os padrões dos tecidos urbanos são definidos pelas características dos arruamentos, dos espaços livres, dos lotes e da volumetria das edificações. As inter-relações desses quatro componentes distinguem cada fase da evolução urbana. REIS FILHO ${ }^{25}$, no texto Quadro da Arquitetura no

\footnotetext{
22 Código de Obras e Edificações do Município de São Paulo, lei no 11.228 de 25.6.1992, artigo 9.5

23 SOUZA, (op.cit., p.129).

24 SOMEKH, Nádia, (1987, p.23).

25 REIS FILHO, Nestor Goulart, Quadro da Arquitetura no Brasil (@1970 - $7^{\mathrm{a} e d .1995) .}$
} 
Brasil, analisa toda a evolução da arquitetura e urbanismo no Brasil. Destacamos aqui algumas das fases mais significativas para São Paulo.

a) Século XVIII, Urbanismo Colonial, Sociedade Escravocrata, apoiada na grande disponibilidade de mão-de-obra, os arruamentos, geralmente sem calçadas, são definidos pelas casas; as ruas correspondem aos espaços que sobram, entre as construções; as moradias tanto térreas como sobrados, são geminadas, ocupando toda a largura do lote. Predominam as construções em taipa de pilão.
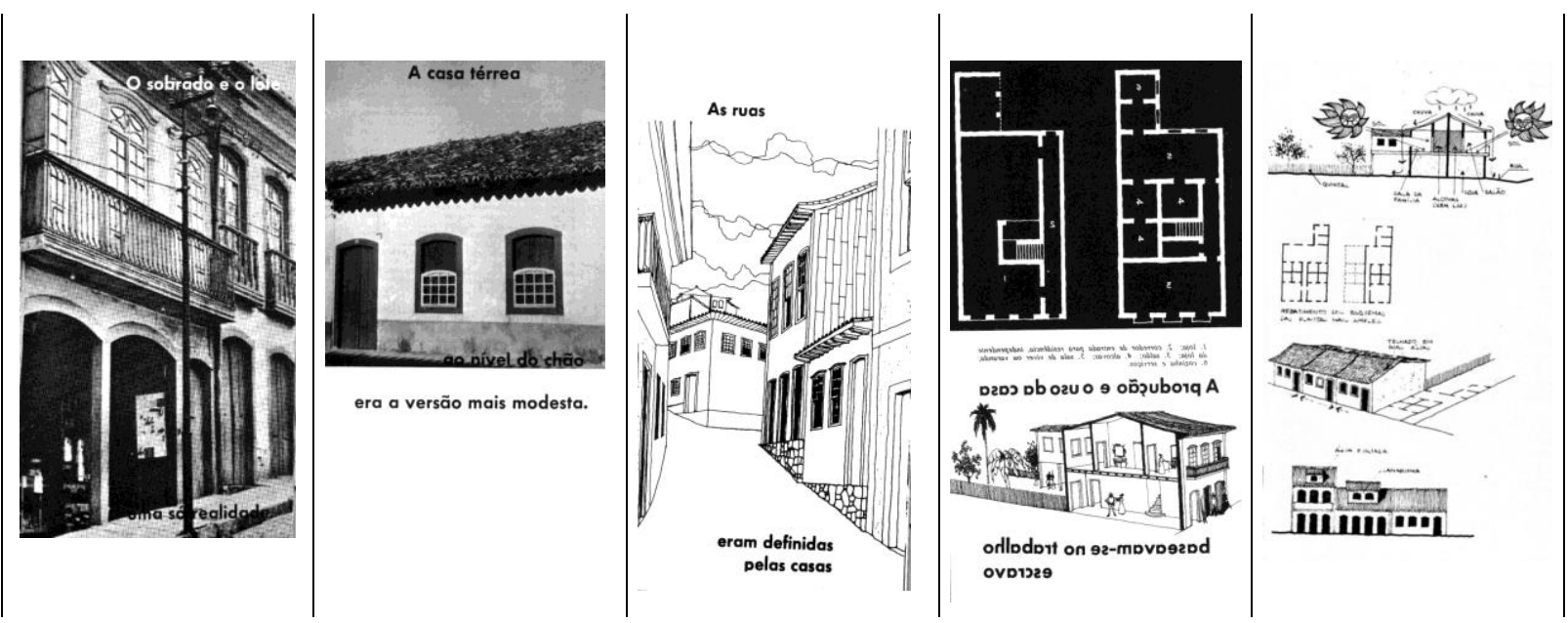

Figura 2-1: Construções e arruamentos no século XVIII.(fonte: Quadro da Arquitetura no Brasil, op.cit. 25).

b) A partir da segunda metade do século XIX, o auge da Cultura do Café, a supressão do tráfico de escravos, a Proclamação da República e o início da imigração européia, são ocorrências que propiciam inovações como o surgimento de casas com porão alto, com entrada e jardins laterais; definem-se os lotes mais amplos e as construções se libertam dos limites do terreno, ao menos de um dos lados. Diminui o uso da taipa e predominam o adobe e o tijolo.

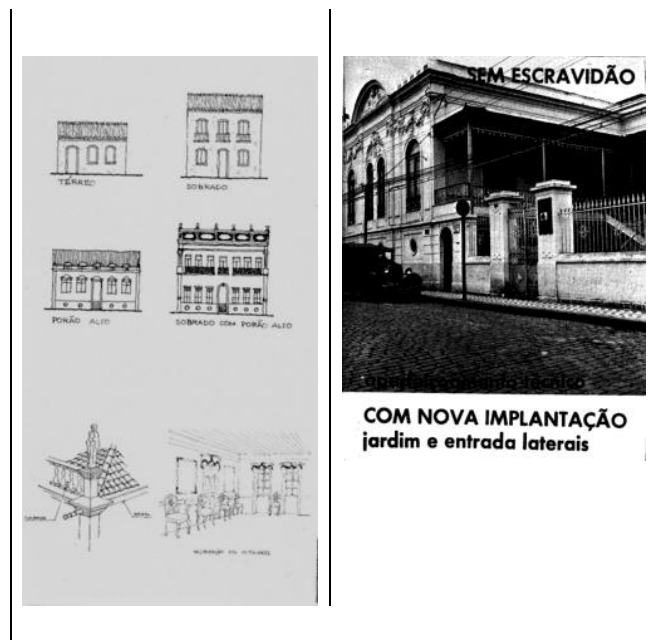

Figura 2-2: Tipologias na segunda metade do século XIX. (fonte: op.cit.25). 


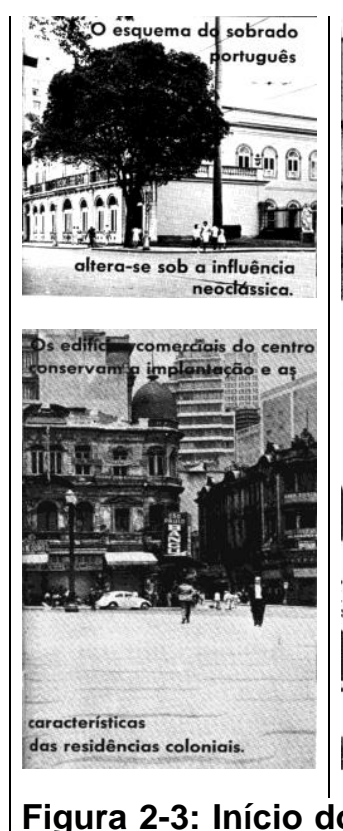

Figura 2-3: Início do século $X X$. (fonte: op.cit.25)
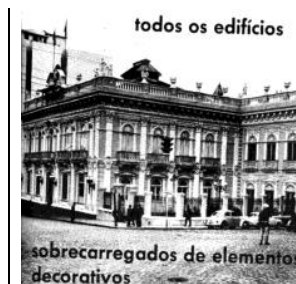

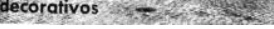

Afastamento da rua, निक्षor
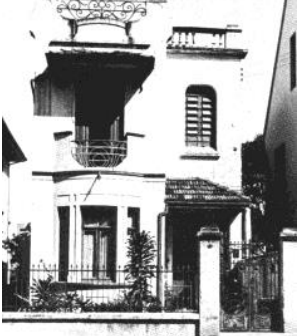

ofo

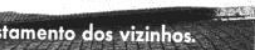

c) Início do século XX até 1920, os edifícios comerciais e residenciais no Centro ainda são geminados, predomina a influência neoclássica, sobrecarregando as edificações com elementos decorativos, valorizando e trabalhando mais a fachada da frente em detrimento da parte posterior das construções, procura-se preservar as características das residências coloniais. Nos bairros, as moradias se afastam dos vizinhos, com recuos em toda a volta, inclusive da rua, com um jardim frontal, que a isola no centro do lote.

d) Entre 1920 e 1945 tem início o grande desenvolvimento da industrialização paulista e a consolidação da acentuada influência cultural européia no Brasil, inclusive assimilando-se as reformulações urbanas lá realizadas ${ }^{26}$, com quarteirões totalmente construídos e edificações com altura uniforme, modelo que acaba sendo adotado nos centros de nossas cidades. Nas palavras de REIS $\mathrm{FILHO}^{27}$ "Predominavam ainda as idéias arquitetônicas e urbanísticas do século XIX, a despeito das amplas mudanças de condições gerais e, como conseqüência, buscava-se a aplicação dos modelos da Paris
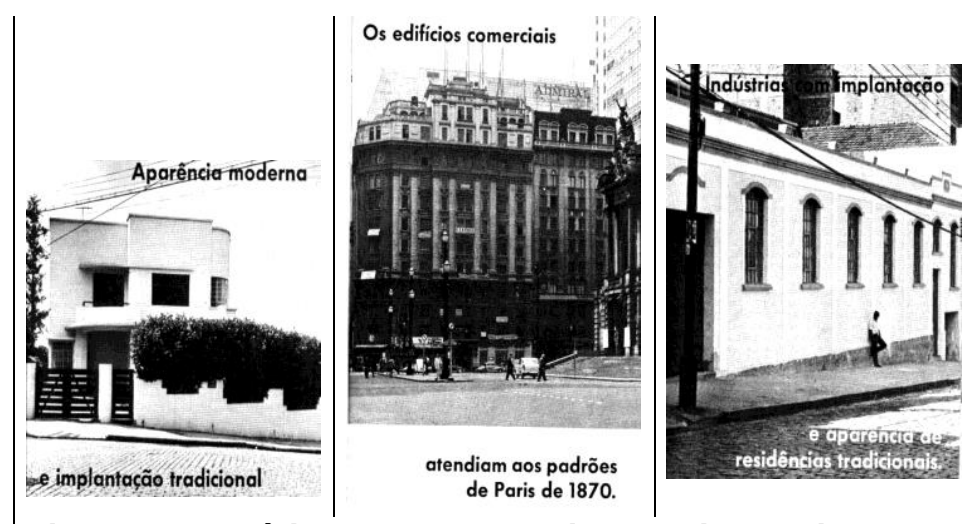

Figura 2-4: Início do desenvolvimento industrial. (fonte: op.cit.25).

de Haussmann, com quarteirões compactos, superedificados e superpovoados".

\footnotetext{
${ }^{26}$ São exemplos significativos de padrões urbanos europeus adotados nas cidades brasileiras: 1)A nova Lisboa, no trecho de La Baixa, criada por Manuel da Maia e Eugenio de Santos, para reconstruir a capital portuguesa destruída por um terremoto em 1755 (ver Fig.2-5); 2) O Plano de Ampliação de Barcelona, elaborado por Ildefons Cerdà (1859), para além das muralhas que a cercaram até 1856, uma cidade com amplas ruas ortogonais, quarteirões quadrados, cantos chanfrados e jardins internos; somente duas diagonais quebravam o quadriculado (ver Fig.2-6). Também é de Cerdà La Teoria General de la Urbanización (1867); 3)Entre 1853 e 1870, a implantação em Paris pelo prefeito Barão Georges Eugene Haussmann, de grandes avenidas longitudinais e transversais, triangularam o traçado urbano concêntrico que predominava anteriormente, são características as edificações geminadas com altura padronizada (ver Fig.2-7).

${ }^{27}$ REIS FILHO, Nestor Goulart, (๑1970, p.80).
} 


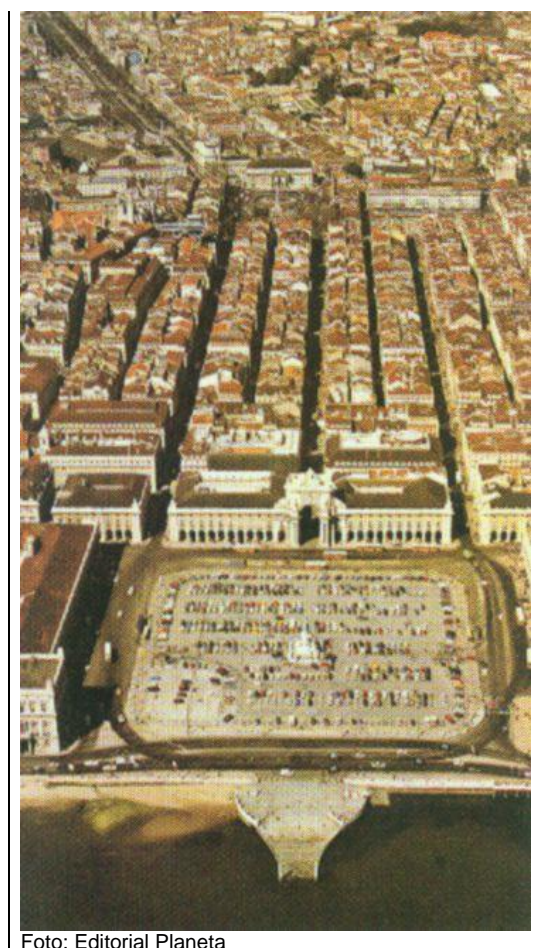

Figura 2-5: Lisboa refeita após o terremoto de 1755.

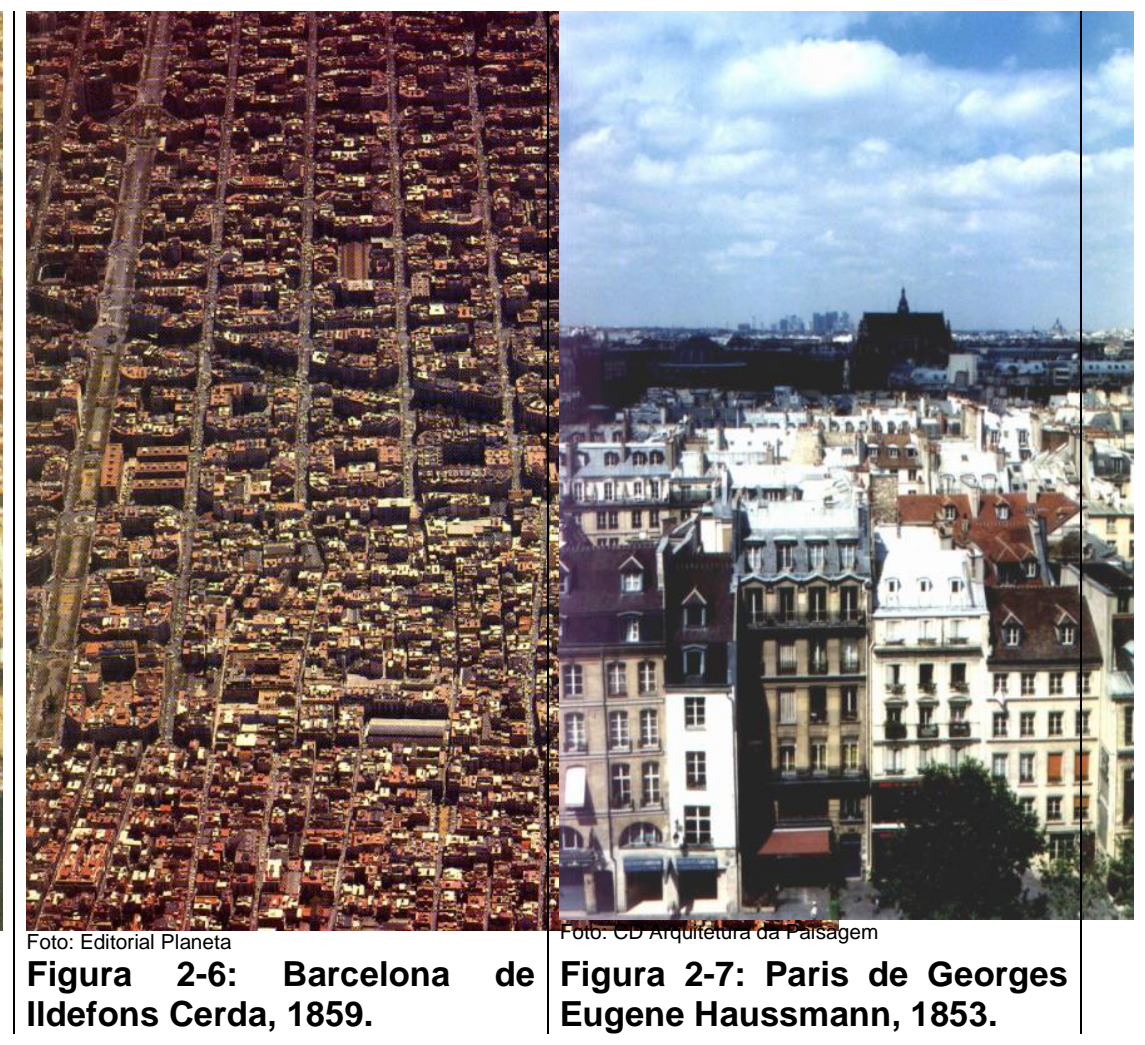

Ildefons Cerda, 1859.

Mesmo antes do final da Segunda Guerra Mundial, São Paulo já despontava como o maior centro industrial da América do Sul; a periferia se expandia, proliferavam as vilas operárias, os conjuntos de sobradinhos geminados; e a verticalização se estabelecia na área central e vizinhanças.

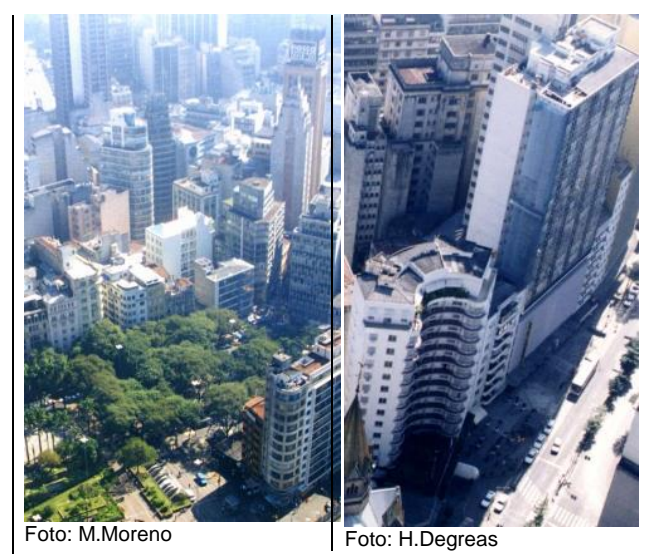

Figura 2-8: Verticalização geminada.

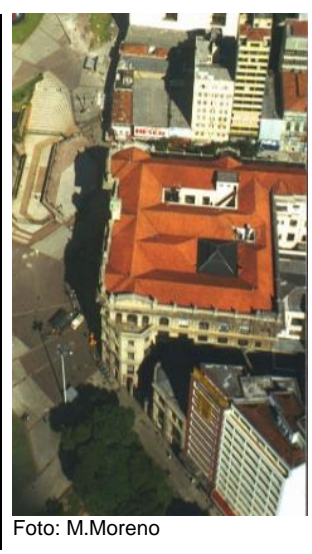

Nessa fase, os padrões de verticalização são os prédios geminados, chegando até as divisas laterais e até ao alinhamento, tudo isso na altura total dos prédios, seja com seis, dez ou mais andares.

e) De 1945 a 1964 temos a fase de maior industrialização e início da metropolização e da verticalização de São Paulo. A televisão (1950) se consolida como importante meio de comunicação ditando comportamentos e ideais de consumo, ocorre intensa migração nacional, expande-se a periferia, proliferam os bancos, a inauguração do 
prédio do Banco do Estado de São Paulo (1947), na época o maior do Brasil, marcam a cidade como núcleo sócio-econômico. Tudo isso vem favorecer a proliferação (1948) das incorporações imobiliárias, popularizando o condomínio. A carência de moradia estimula a construção de "kitchenettes". Modificações no Código de Obras passam a permitir banheiros sem janelas, apenas com dutos de ventilação.

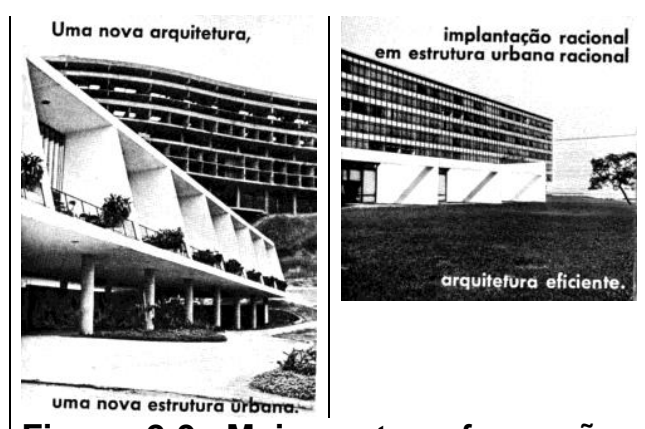

Figura 2-9: Maiores transformações pós 1945. (fonte: op.cit.25)
Em Brasília, o Plano Piloto se materializa, no ano de 1960, e os ideais modernistas são postos em prática; na superquadra não ocorre a tradicional subdivisão em lotes, os espaços livres são abertos e pertencem a todos.

Em São Paulo, a estrutura urbana tradicional, fragmentada em lotes, dificulta mas não impede que se adote implantação do edifício no meio do lote, recuado de todas as divisas, permitindo abrir janelas para todas as fachadas. O edifício passa a ser pensado como um todo, todas as fachadas são importantes, não só a fachada da frente. $O$ condomínio Louveira no bairro de Higienópolis, projetado por João Vilanova Artigas e Carlos Cascaldi em 1946, é considerado como um dos mais significativos desta fase de verticalização em São Paulo e foi implantado isolado das divisas e do chão pelos pilotis; também foi dos primeiros a ter os jardins no centro do lote.

Nesta fase convivem em São Paulo e nas outras cidades brasileiras, os dois padrões de implantação das edificações verticalizadas. Muitos edifícios construídos dentro dos princípios modernistas adotam a implantação tradicional encostando-se nas divisas e ocupando totalmente o lote; dentre os quais podemos citar o edifício do jornal O Estado de São Paulo (1946), hoje Diário Popular, de Jacques Pilon e Adolf Franz Heep. Outro exemplo marcante, por ser proveniente da vanguarda da arquitetura paulista, é a sede do IAB-SP (1947) projetado por grande equipe de arquitetos, entre eles Rino Levi e Hélio Duarte; sem dúvida, uma construção moderna, porém, com implantação tradicional encostada nas divisas e ocupando todo o lote.

f) Fase 1964 a 2000, São Paulo se consolida como núcleo metropolitano, a infraestrutura evoluiu, aumentou a rede de distribuição de água, instalou-se o Metrô, elaboraram-se planos diretores urbanos e metropolitanos, aprimorou-se a Legislação 
de Parcelamento, Uso e Ocupação do Solo com a oficialização da Lei no 7805 de 01 novembro 1972 (Lei do Zoneamento), acelerou-se nas periferias o processo de expansão, inicialmente horizontal, porém, a partir da década de 70, também se observam diversos focos de verticalização.

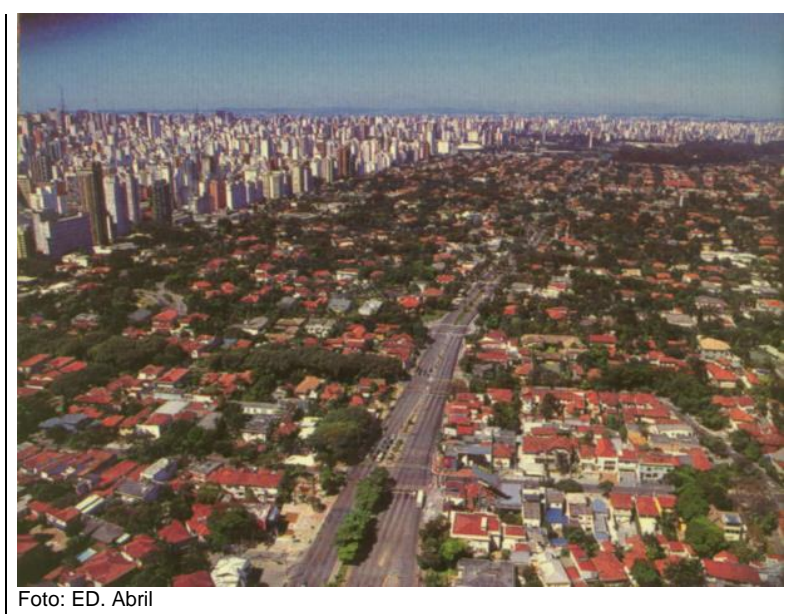

Figura 2-10: Três décadas de Zoneamento consolidam os vários tipos de tecido urbano.

No ano 2000, a morfologia do tecido urbano verticalizado paulistano mostra claramente as várias tramas determinadas pela Legislação do Zoneamento implantada em 1972, com exceção dos trechos que já estavam consolidados naquela data.

Nas zonas em que se permite a verticalização para moradia, o padrão é o edifício isolado no meio do lote, embora seja permitido que os subsolos para garagens encostem-se às divisas e suas áreas não sejam computadas no Coeficiente de Aproveitamento ${ }^{28}$.

\subsection{A Legislação Urbana na Cidade de São Paulo}

Normalmente se imagina que a legislação urbana organize e comande 0 crescimento da cidade, determinando as áreas de expansão, as densidades e consiga adequar as relações espaciais entre as diversas atividades, entre os vários usos. Estudos aprofundados que nos precederam, TARALLI ${ }^{29}, \operatorname{SOUZA}^{30}$ e MACEDO ${ }^{31}$, mostram que em São Paulo isso não acontece. Na maioria das vezes, a legislação vem oficializar situações já consolidadas; seja porque o crescimento tem sido muito rápido, como no caso dos loteamentos irregulares, ou porque a iniciativa privada se antecipa estabelecendo padrões mais elaborados de apropriação do território, como por exemplo, nos empreendimentos da Cia. City e seus bairros jardim.

\footnotetext{
28 Dependendo das condições topográficas e a cota da entrada do edifício, podem ocorrer implantações em que um ou vários pavimentos chegam até às divisas do terreno. Há casos em que as construções para garagens, nas divisas do lote sobressaem quatro andares acima do nível original do terreno.

${ }^{29}$ TARALLI, Cibele Haddad - Ambiente Construído e Legislação: o visível e o imprevisível, São Paulo, Tese de Doutorado, FAU USP, 1997.

30 SOUZA, Maria Adélia Aparecida de - A Identidade da Metrópole, São Paulo, Editora Hucitec/Edusp, 1994.

31 MACEDO, Silvio Soares - São Paulo, Paisagem e Habitação Verticalizada: os espaços livres como elementos do desenho urbano, São Paulo, Tese de Doutorado, FAU USP, 1988.
} 
O resultado material, formal da cidade sobre o território, é conseqüência das relações entre: o Estado (através das leis), o Capital (impulsionando o mercado imobiliário) e a Sociedade (do consumo, da cultura de massas e da luta de classes). Como o Estado é a representação dos outros envolvidos e a Sociedade por várias vezes tem se omitido ou imagina que terá vantagens junto com o Capital, é freqüente que a legislação também se omita ou atenda aos interesses financeiros. Segundo MACEDO ${ }^{32}$ "... as leis do zoneamento versando pouco sobre a qualidade de habitabilidade e configuração do espaço urbano, atendo-se a especificações funcionais de uso do solo, desprezando estruturas consolidadas pela população como os bairros e o próprio sítio urbano" não parece contribuir para melhorar a qualidade ambiental urbana e nem implementa a qualidade de vida dos cidadãos.

Três tipos de legislações norteiam a evolução urbana de São Paulo: a) Leis Urbanísticas; b) Códigos de Obras e Edificações; e c) Códigos Sanitários.

Enquanto os dois primeiros são definidos pelo Legislativo Municipal (Câmara de Vereadores), o terceiro tipo é estabelecido pelo Legislativo Estadual (Assembléia Legislativa dos Deputados Estaduais) e geralmente só é aplicado nos municípios que não dispõem de legislação própria.

Apresentamos uma análise cronológica da evolução da legislação edilícia paulistana, trilhando o mesmo caminho de SOUZA, que considera quatro períodos balizados pelas datas de publicação das leis mais significativas.

Primeiro Período até 1934 - Em termos urbanísticos caracteriza-se por legislações que determinam intervenções pontuais regulamentando traçados de ruas e alinhamentos: o "Código de Posturas Municipais" de 1886 "não tinha nenhuma preocupação com os aspectos referentes ao crescimento da cidade... Proibe o corte de lenha, cuida da salubridade ao proibir Curtumes no perímetro urbano e deixa para a Câmara Municipal definir os locais para Casas de Saúde e de Tratamento de Loucos"333; entre 1897 e 1920, uma série de Leis regulamentam o traçado, recuos e alinhamentos da Avenida Paulista, Avenida Higienópolis, Avenida Tiradentes, Avenida Água Branca e da Rua Barão de Itapetininga; é a Lei no2611 de 1923 que

\footnotetext{
32 MACEDO, (op.cit. p.11).

${ }^{33}$ SOUZA, (op.cit. p.221)
} 
estabelece as primeiras normas sobre arruamentos.
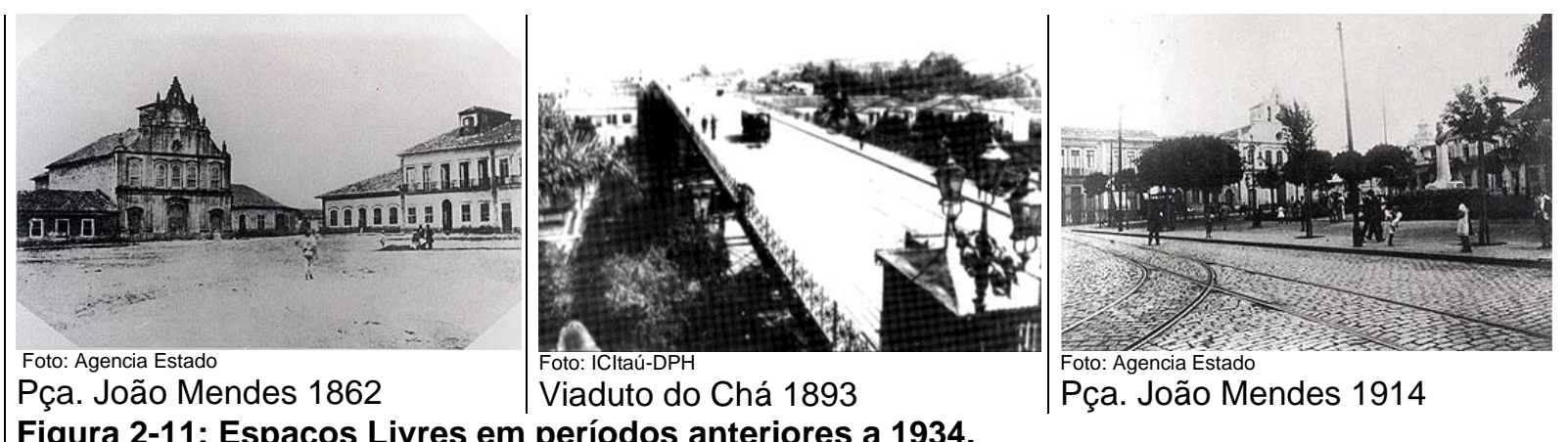

Figura 2-11: Espaços Livres em períodos anteriores a 1934.

Quanto às edificações, a primeira normatização foi a Lei n³427, o "Código Artur Sabóya" de 1929, complementado e consolidado pelo Ato n663 de 1934, tratava dos problemas de salubridade do edifício e de suas características geométricas, relacionando a altura da edificação com a largura da rua.

No âmbito estadual, o Decreto 끈33 de 1894 edita 0 1ํㅡ Código Sanitário e o ํㅜ é estabelecido em 1911.

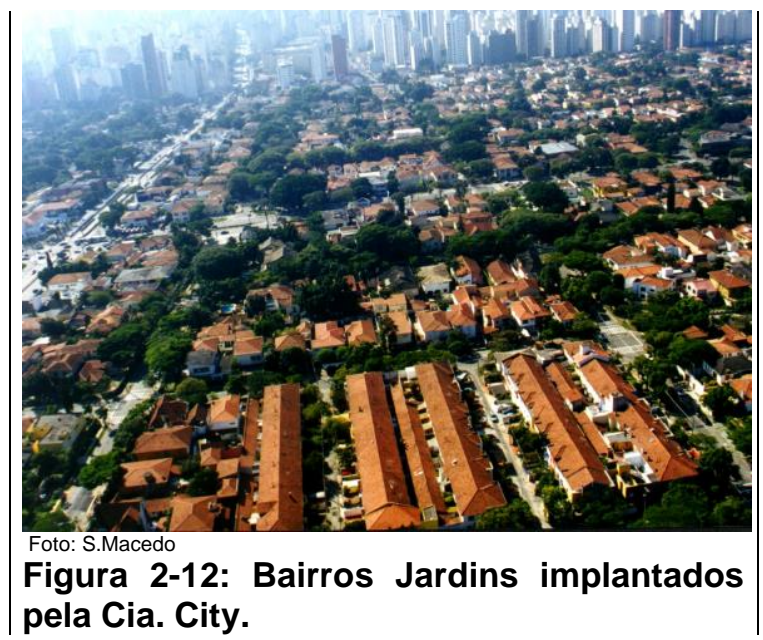

Segundo Período de 1935 a 1955 - No aspecto urbanístico destaca-se a legislação dos bairros de elite. Surgem os primeiros prédios para fins residenciais em Higienópolis. A Prefeitura realiza alterações no sistema viário, com alargamentos, prolongamentos e abertura de novas vias.

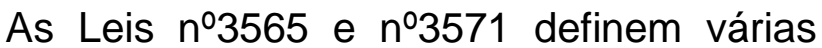
ruas para uso estritamente residencial; a Cia. City introduz os loteamentos padrão cidade-jardim, com normas de uso e ocupação de baixa densidade. Ato №1366 de 1938 estabelece gabarito máximo para zona central. A partir de 1940 um conjunto de leis e decretos-lei define gabaritos e recuos em diversas ruas; o Decreto-lei n99 de 1941 incorpora o padrão introduzido pela Cia. City.

O Código de Obras através da Lei nำ4506 de 1954 recebe várias alterações ampliando os recuos. A Lei Estadual №1561 de 1951 estabelece novo Código Sanitário. 
Terceiro Período de 1956 a 1972 - Na legislação urbana, a Lei n4805 de 1955 é a primeira tentativa de implantar em toda a cidade um zoneamento de usos, "Mais uma vez é a preservação da vizinhança (com o objetivo de valorização fundiária e imobiliária) que vai ditar a norma: preocupação com os ruídos e a poluição industrial (depois de meio século de desenvolvimento industrial no município)". ${ }^{34}$ Essa Lei não chega a delimitar e definir as áreas, mas conceitua as zonas em: estritamente residenciais, predominantemente residenciais, mistas e fabris.

A Lei n5261, "Lei Anhaia" de 1957, define os limites de aproveitamento dos lotes em cada zona. Somente o decreto n⿳3962 de 1958 define os perímetros consolidando a situação existente. Durante quase uma década, inúmeros embates políticos tentam substituir a Lei Anhaia que estava sendo burlada.

A Lei no6465 de 1963 define as faixas reservadas para a futura implantação do Metrô. A Lei no6877 de 1966 altera a Lei Anhaia ampliando o coeficiente de aproveitamento dos terrenos para 6 , exceto para os prédios de garagens que podem chegar ao coeficiente 15.

Em 1968, publica-se o PUB (Plano Urbanístico Básico), logo a seguir o PMDI (Plano Metropolitano de Desenvolvimento Integrado) e a partir dos planos anteriores surge a Lei ำ7488, PDDI (Plano Diretor de Desenvolvimento Integrado do Município de São Paulo) de 1971, que detalha os elementos do planejamento físico-territorial, distribuindo as atividades, visando descongestionar o centro principal e reduzir os deslocamentos.

A Lei ํㅜ488, Lei do Plano Diretor, no capítulo V, estabelece, do artigo 18 ao 25, as disposições do zoneamento de usos. A Lei no7085 de 1972, conhecida como Lei do Zoneamento, complementa o PDDI regulamentando as áreas de cada zona de uso, chegando ao Coeficiente Máximo de Aproveitamento do terreno que é Quatro. O Decreto-Lei no211 de 1970 aprimora o Código Sanitário.

Quarto Período de 1973 a 2000 - Representando maior rigor no controle da verticalização, a Lei do Zoneamento de 01/11/1972 dividiu a cidade em oito zonas (de Z1 a Z8), procurando obedecer às tendências de ocupação já existentes. "Essa Lei de Zoneamento de 1972 é a primeira que, além de abranger toda a cidade, trata de maneira integrada as normas para o uso do solo, lotes e sua ocupação,

${ }^{34}$ SOUZA, (op.cit. p.223). 
preocupando-se ainda com a expansão das áreas edificadas... Ao longo da década de 70, essa lei vai sendo mutilada, passando por uma série de modificações, processo que, aliás, perdura até hoje. A prática de intervenção na cidade por desbloqueios pontuais; aliada ao expediente do decurso de prazo, é comum. ... É importante destacar que na década de 70 acentua-se a perda de autonomia municipal, simbolizada pela crise fiscal ou tributária, estratégia marcante do regime militar, que tem enorme influência, sem dúvida, na ideologia do adensamento urbano. "35
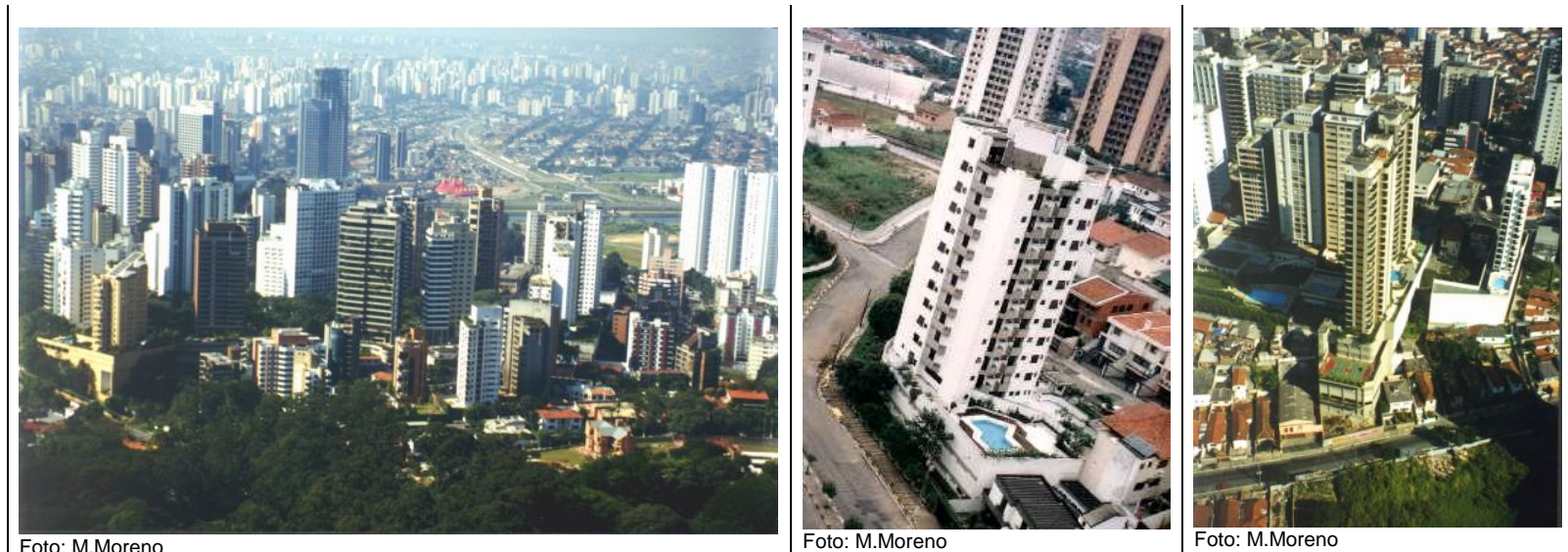

Figura 2-13: Implantação Típica: Adaptação às parcelas criadas para moradias horizontais; Edifício no centro do lote com recuos de todos os lados; Térreo plano sobre os subsolos para garagens que chegam até as divisas, ignorando a topografia; e Os espaços livres são os remanescentes.

Na lei do Zoneamento, os Usos foram divididos em seis Categorias: residencial $(\mathrm{R})$, comercial (C), serviços (S), industriais (I), institucionais (E) e usos especiais (E4).

\begin{tabular}{|c|l|c|l|}
\hline Categorias & & Categorias & \\
\hline R1 & Residência Unifamiliar & S2 & Serviços Diversificados \\
\hline R2 & Residência Multifamiliar várias no lote & S3 & Serviços Especiais \\
\hline R2.01 & Unidades agrupadas horizontalmente & $\mathrm{I} 1$ & Indústrias não Incômodas até $500 \mathrm{~m}^{2}$ \\
\hline R2.02 & Unidades agrupadas verticalmente & $\mathrm{I} 2$ & Indústrias diversificadas \\
\hline R3 & Conjunto residencial c/ C1 e S1 & $\mathrm{I} 3$ & Indústrias Especiais mais 5000 func. \\
\hline C1 & Comércio Varejista Local até $250 \mathrm{~m}^{2}$ & $\mathrm{E} 1$ & Instituição âmbito Local até $250 \mathrm{~m}^{2}$ \\
\hline C2 & Comércio Varejista Diversificado & $\mathrm{E} 2$ & Instituição Diversificada até $2500 \mathrm{~m}^{2}$ \\
\hline C3 & Comércio Atacadista & $\mathrm{E} 3$ & Instituições Especiais \\
\hline S1 & Serviços de âmbito Local até $250 \mathrm{~m}^{2}$ & $\mathrm{E} 4$ & Usos Especiais \\
\hline
\end{tabular}

Quadro 2-1: Categorias de Usos da Lei do Zoneamento da Cidade de São Paulo.

${ }^{35}$ sOUZA, (op.cit. p.234). 
Cada uma das Zonas comporta alguns dos usos, conforme o quadro a seguir.

\begin{tabular}{|c|c|c|c|}
\hline Zona & Uso & $\begin{array}{c}\text { Taxa } \\
\text { Ocupação } \\
\end{array}$ & \begin{tabular}{|c|} 
Coeficiente de \\
Aproveitamento \\
\end{tabular} \\
\hline $\mathrm{Z1}$ & $\begin{array}{c}\text { Estritamente Residencial, densidade baixa. } \\
\text { R1, E4 }\end{array}$ & Até 0,5 & Até 1 \\
\hline$\overline{Z 2}$ & $\begin{array}{l}\text { Predominantemente Residencial, densidade baixa. } \\
\text { R1, R2, R3, C1, E1, S1, I }\end{array}$ & Até 0,5 & Até 1 \\
\hline Z3 & $\begin{array}{l}\text { Predominantemente Residencial,densidade média. } \\
\text { R1, R2, R3, C1, C2, E1, S1, S2, I } 1\end{array}$ & Até 0,5 & Até 2,5 \\
\hline$\overline{Z 4}$ & $\begin{array}{c}\text { Uso Misto, densidade média - alta. } \\
\text { R1, R2, R3, C1, C2, E1, E2, S1, S2, I } 1\end{array}$ & Até 0,7 & Até 3 \\
\hline Z5 & $\begin{array}{c}\text { Uso Misto, densidade alta. } \\
\mathrm{R} 1, \mathrm{R} 2, \mathrm{R} 3, \mathrm{C} 1, \mathrm{C} 2, \mathrm{E} 1, \mathrm{E} 2, \mathrm{~S} 1, \mathrm{~S} 2, \mathrm{I} 1\end{array}$ & Até 0,8 & Até 3,5 \\
\hline$\overline{Z 6}$ & $\begin{array}{l}\text { Predominantemente Industrial } \\
\text { C1, C2, C3, S3, I } 2 \\
\end{array}$ & Até 0,7 & Até 1,5 \\
\hline $\mathrm{Z7}$ & $\begin{array}{l}\text { Estritamente Industrial } \\
\qquad \text { I } 2,13, \mathrm{C} 3, \mathrm{~S} 3\end{array}$ & Até 0,4 & Até 0,8 \\
\hline Z8 & $\begin{array}{c}\text { Usos Especiais } \\
\text { (objeto de planos específicos) }\end{array}$ & \multicolumn{2}{|c|}{ Estabelecidos para cada uso } \\
\hline
\end{tabular}

Quadro 2-2: Síntese da Lei do Zoneamento da Cidade de São Paulo. (fonte: Lei nº7805/72)

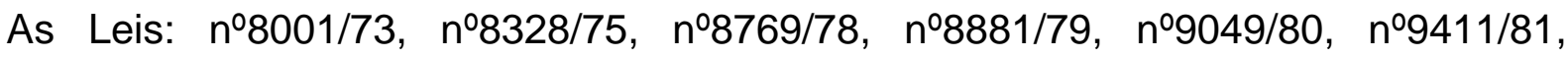
n-9413/81, nำ10.015/85, nำ10.209/86, n-10.137/86 e os Decretos nำ11.108/74 e nº17.494/81, são regulamentações e alterações da Lei do Zoneamento. Até 1991 foram incorporadas mais onze novas zonas (da Z9 até Z19).

\begin{tabular}{|c|c|c|c|}
\hline Zona & Uso & $\begin{array}{c}\text { Taxa } \\
\text { Ocupação }\end{array}$ & $\begin{array}{l}\text { Coeficiente de } \\
\text { Aproveitamento }\end{array}$ \\
\hline Z9 & $\begin{array}{c}\text { Estritamente Residencial, densidade baixa. } \\
\text { R1, R2 }\end{array}$ & Até 0,5 & Até 1 \\
\hline Z10 & $\begin{array}{c}\text { Estritamente Residencial, densidade média. } \\
\text { R1, R2, R3. }\end{array}$ & Até 0,5 & Até 2,5 \\
\hline Z11 & $\begin{array}{l}\text { Uso Misto, densidade baixa. } \\
\text { R1, R2, R3, C1, E1, S1 }\end{array}$ & Até 0,5 & Até 1 \\
\hline Z12 & $\begin{array}{l}\text { Uso Misto, densidade média. } \\
\text { R1, R2, R3, C1, C2, E1, S1, S2 }\end{array}$ & Até 0,5 & Até 2,5 \\
\hline Z13 & $\begin{array}{c}\text { Uso Misto, densidade baixa. } \\
\text { R1, R2, R3, C1, C2, E1, E2, S1, S2, I } 1\end{array}$ & Até 0,5 & Até 1 \\
\hline Z14 & $\begin{array}{l}\text { Residencial, baixíssima densidade, lote } 2000 \mathrm{~m}^{2} . \\
\mathrm{R} 1, \mathrm{C} 1, \mathrm{~S} 1, \mathrm{E} 2\end{array}$ & Até 0,26 & Até 0,26 \\
\hline Z15 & $\begin{array}{c}\text { Residencial, baixíssima densidade, lote } 5000 \mathrm{~m}^{2} \text {. } \\
\mathrm{R} 1\end{array}$ & Até 0,12 & Até 0,12 \\
\hline$\overline{Z 16}$ & $\begin{array}{l}\text { Uso Misto; baixíssima densidade, lote } 5000 \mathrm{~m}^{2} . \\
\text { C2, S1, E1 }\end{array}$ & Até 0,1 & Até 0,2 \\
\hline Z17 & $\begin{array}{c}\text { Transição, usos de âmbito local, densidade baixa. } \\
\text { R1, R2, R3, C1, E1, S1 }\end{array}$ & Até 0,5 & Até 1 \\
\hline$\overline{Z 18}$ & $\begin{array}{c}\text { Transição, usos diversificados, densidade baixa. } \\
\mathrm{R} 1, \mathrm{R} 2, \mathrm{R} 3, \mathrm{C} 1, \mathrm{E} 1, \mathrm{~S} 1\end{array}$ & Até 0,5 & Até 1 \\
\hline Z19 & $\begin{array}{l}\text { Uso misto, densidade média. } \\
\mathrm{R} 1, \mathrm{R} 2, \mathrm{C} 1, \mathrm{C} 2, \mathrm{~S} 1, \mathrm{~S} 2, \mathrm{E} 1\end{array}$ & Até 0,6 & Até 2,5 \\
\hline
\end{tabular}

Quadro 2-3: Resumo das novas Zonas estabelecidas entre 1972 e 1991. (fonte: SEMPLA)

Obs: As Z18 e Z19 têm controle do gabarito das construções, máximo 25m de altura. 
Um aspecto que tem permitido que se burle o zoneamento, refere-se às várias anistias propostas, visando regularizar edifícios e loteamentos que não se enquadravam na Legislação. Entre 1979 e 1989, foram editados onze leis ou decretos de anistia, oficializando algum tipo de irregularidade. É a legitimação do informal urbano, apesar da Lei de 1972.

A Lei nº8266 de 1975 introduz novo Código de Obras e a Lei nำ11.228 de 1992 o reformula novamente.

A Lei estadual nำ12.342 de 1978 altera o Código Sanitário.

\subsection{Os Espaços Livres Resultantes}

A palavra Espaço vem do latim "spatiu", é um substantivo que pode significar: A área ou o volume entre limites determinados, ou a distância entre dois pontos. Lugar mais ou menos bem delimitado, cuja área pode conter alguma coisa; lugar. Período ou intervalo de tempo. Em termos figurativos pode atribuir materialidade a elementos subjetivos como: espaço psicológico; espaço cultural... . Aqui o termo Espaço tem o sentido de área ou volume delimitado pela percepção sensorial do ser humano.

Livre é um adjetivo, também originado do latim "liber" e significa: Desprendido, Solto, Desimpedido, Independente, Disponível, Sem obstáculos, Desembaraçado, Desocupado, Espontâneo, Natural.

É significativo notar que as expressões: Natural e Espontâneo estejam associadas à palavra Livre. No caso os Espaços Livres nos lembram maior aproximação com a Natureza do que os Espaços das Edificações.

Espaços Livres são todos os espaços sem obstáculos, não contidos entre as paredes e tetos dos edifícios construídos pela sociedade. Também é sinônimo de Espaço Externo.

Espaços livres são os espaços não delimitados por coberturas (tetos). "No contexto urbano tem-se como espaços livres todas as ruas, praças, largos, pátios, quintais, parques, jardins, terrenos baldios, corredores externos, vilas, vielas e outros mais por onde as pessoas fluem no seu dia a dia em direção ao trabalho, ao lazer ou à moradia ou, ainda, exercem atividades específicas tanto de trabalho, como lavar roupas (quintal ou no pátio), consertar carros, etc., como de lazer (na praça, no playground, etc.)". 36

\footnotetext{
${ }^{36}$ MACEDO, Silvio Soares - Espaços Livres, São Paulo, FAUUSP, edição do autor, abril 1995.
} 
Aos Espaços em geral e aos Espaços Livres em particular, associam-se atributos como: Público ou Particular, Coletivo ou Privado. Público significa que é propriedade de todas as pessoas, sem restrições; Particular é propriedade de um ou de alguns; Coletivo significa que não é para uso individual, é para ser usado por vários; Privado quer dizer para uso individual ou uso de algum grupo específico. O quadro 2.4 apresenta as possibilidades de apropriação dos Espaços Livres.

\begin{tabular}{|c|c|c|}
\hline $\begin{array}{c}\text { Exemplos de Possibilidades nos } \\
\text { Espaços Livres }\end{array}$ & $\begin{array}{c}\text { Público (é propriedade de } \\
\text { todos) }\end{array}$ & $\begin{array}{c}\text { Particular (é propriedade de } \\
\text { um ou de alguns) }\end{array}$ \\
\hline $\begin{array}{c}\text { Uso Coletivo (para uso de } \\
\text { varios) }\end{array}$ & $\begin{array}{c}\text { Ruas, travessas, becos, } \\
\text { avenidas, praças, etc. } \\
\text { destinados à circulação pública } \\
\text { de veículos e de pedestres. } \\
\text { Exemplo: Espaços da Av. } \\
\text { Paulista. }\end{array}$ & $\begin{array}{c}\text { Ruas, travessas, praças, etc. } \\
\text { destinados à circulação } \\
\text { particular de veículos e de } \\
\text { pedestres. } \\
\text { Exemplo: Espaços de } \\
\text { Condomínios como Alphaville. }\end{array}$ \\
\hline $\begin{array}{c}\text { Uso Privado (usado por uma } \\
\text { pessoa ou por um grupo } \\
\text { específico) }\end{array}$ & $\begin{array}{c}\text { Espaços públicos utilizados por } \\
\text { grupos específicos. Exemplo:Av. } \\
\text { 23 de Maio, bloqueada para a } \\
\text { Maratona de São Paulo ou para }\end{array}$ & $\begin{array}{c}\text { Espaços e equipamentos } \\
\text { particulares utilizados por } \\
\text { usuários específicos. Exemplo: } \\
\text { quadras de Tênis do Clube } \\
\text { Pinheiros, só para Sócios. }\end{array}$ \\
\hline
\end{tabular}

Quadro 2.4: Possibilidades de Posse e Apropriação dos Espaços Livres.

Embora as palavras Lazer e Recreação tenham o mesmo significado no dicionário, tecnicamente conceitua-se Lazer como sendo o ócio repousante, implicando em locais tranqüilos; enquanto o conceito de Recreação dá a entender a idéia de divertimentos, brincadeiras, esportes, requerendo espaços específicos geralmente dinâmicos e agitados, repletos de atividades, folguedos e alegrias. Podemos fundir os dois conceitos, sob a rubrica Lazer, chamando a Recreação de Lazer Ativo e o Repouso de Lazer Contemplativo.

Freqüentemente, o conceito de Espaços Livres confunde-se com o de Espaços Verdes, Áreas Verdes, Áreas de Lazer, Áreas de Esportes e Áreas de Circulação, sendo às vezes tratados como sinônimos. Macedo ${ }^{37}$, utilizando como referências Miranda Magnoli e Ayako Nishikawa, organiza as idéias conceituando cada uma das expressões.

${ }^{37}$ MACEDO, Silvio Soares (Op. Cit. p.1 a 9). 


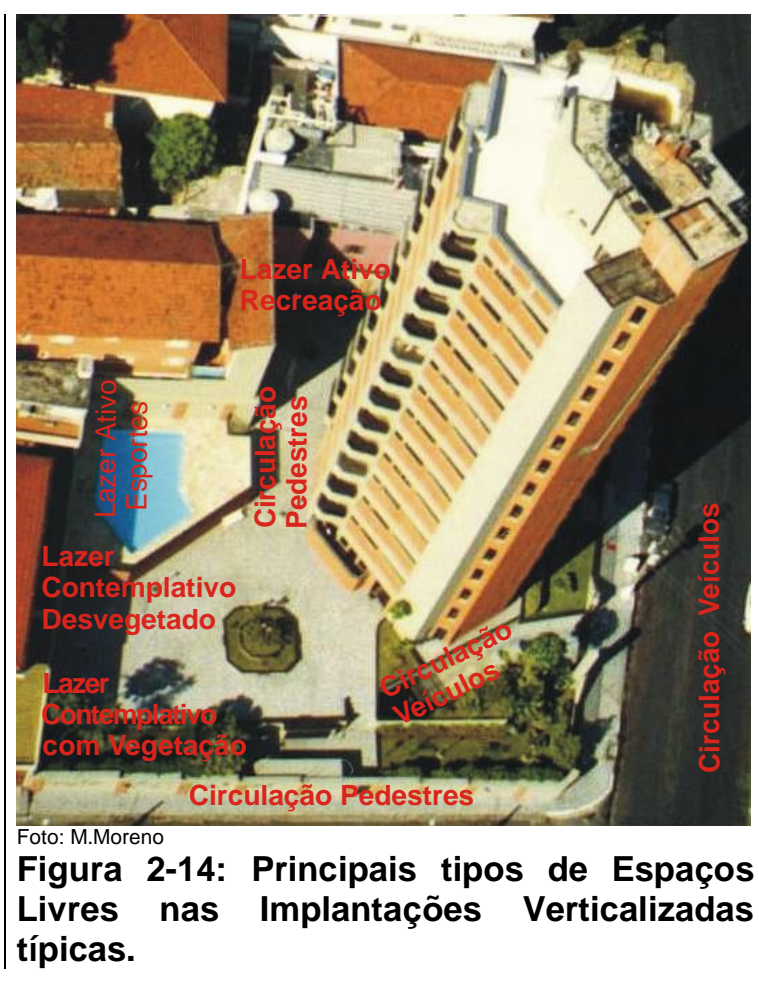

Espaços Verdes: são todas as áreas ou porções do território ocupadas por qualquer tipo de vegetação que tenham algum valor social. $O$ valor social pode estar vinculado à capacidade de produção agrícola, ao interesse para a conservação e a preservação, ao seu valor estético cultural e à sua destinação para o lazer ou a recreação.

Áreas Verdes: conceitualmente englobam os espaços verdes e também áreas que por qualquer motivo tenham vegetação, designando toda e qualquer área plantada, tendo um significado social expressivo ou não. Macedo alerta que o uso desta expressão, para designar o conjunto de áreas de lazer públicas de uma cidade, é imprecisa, pois é sabido que nem todas as praças são áreas de recreação/lazer ou que necessitem estar ajardinadas para cumprir sua função de espaço social.

Áreas de Lazer: todo e qualquer espaço livre de edificação destinado tanto ao Lazer Contemplativo como ao Lazer Ativo (Recreação). Todas as praças urbanas, as praias, os parques e até terrenos vazios, utilizados pela população para jogos e brincadeiras, enquadra-se neste conceito.

Áreas de Esportes: são os espaços destinados às atividades desportivas, que são parte do Lazer Ativo, são atividades praticadas seguindo regras específicas de cada esporte e geralmente com um mínimo de condições e infra-estrutura. Incluem-se nessa categoria, as instalações esportivas como quadras, piscinas e inclusive os terrenos vazios, praças e calçadas, adaptados para práticas desportivas, como jogar futebol ou fazer acrobacias com skates, bicicletas ou patins, com rampas improvisadas.

Sistema de Espaços Livres Públicos de Lazer ou Conservação: é a expressão recomendada para designar o conjunto de áreas públicas de Lazer de uma cidade, pois além de ser conceitualmente mais precisa, evita-se que áreas sem vegetação 
ou sem condições, como canteiros centrais de avenidas ou rotatórias, sejam computadas como áreas verdes.

Áreas de Circulação: espaços destinados à circulação e acesso de veículos e pedestres, englobando a maioria dos espaços livres de edificação, tanto públicos como são os sistemas viários, quanto privados, tais como as vilas e as vias e caminhos nos condomínios.

O Quadro mostra as relações e abrangências entre os diversos tipos de áreas que formam os espaços livres. Convém observar que as Áreas de Lazer não são necessariamente Áreas Verdes.

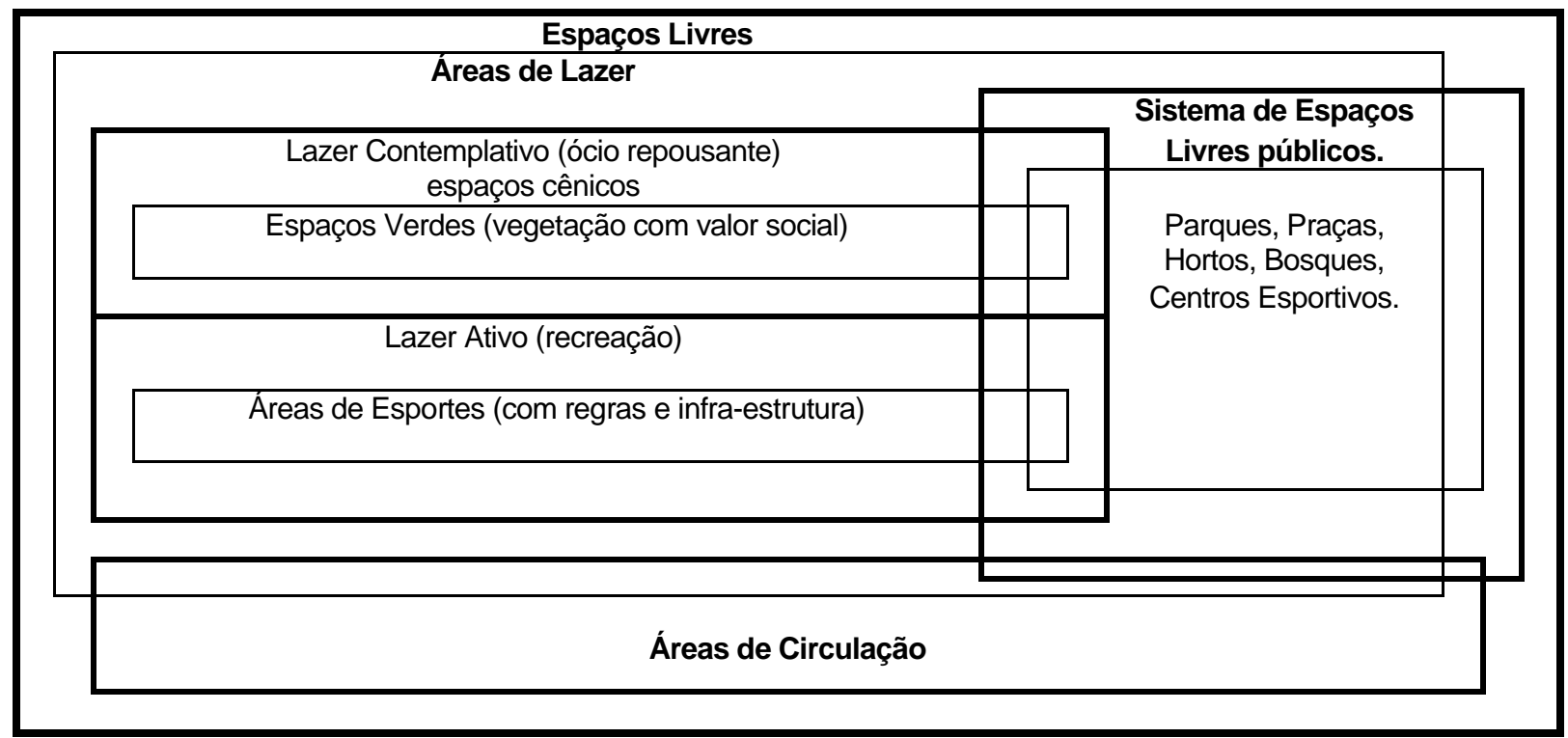

Quadro 2.5: Relações entre os vários tipos de áreas que compõem os Espaços Livres.

Nas quadras verticalizadas urbanas, os Espaços Livres predominantes são as Áreas de Circulação (para veículos e pedestres). As Áreas de Lazer Contemplativo (com e sem vegetação) e as Áreas de Lazer Ativo (para recreação e para esportes) ocupam áreas menores.

Nas cidades em geral, as Áreas de Circulação, tanto públicas como privadas, ocupam mais de cinqüenta por cento do total da Área das quadras, enquanto as Áreas de Lazer (Contemplativo e Ativo), que no caso brasileiro, estão principalmente 
em propriedades privadas, ocupam juntas superfícies que raramente chegam a quinze por cento da área total das quadras analisadas.

Por exemplo, no bairro de Moema em São Paulo, área essencialmente verticalizada, estudamos as seis quadras delimitadas por: rua Juquís, Av. Iraí, Al. Maracatins e Av. Jandira; e obtivemos as áreas apresentadas no quadro 2.6.

Como áreas de circulação de veículos, além das ruas, consideramos também os recuos destinados aos veículos, as vias de acesso às garagens e as áreas dos estacionamentos descobertos. Quanto às áreas de circulação de pedestres, além das calçadas, também computamos todos os caminhos e acessos destinados às pessoas. As áreas para recreação são muito pequenas, o playground em geral não passa dos $20 \mathrm{~m}^{2}$. As áreas para esportes como as quadras poliesportivas e, principalmente, as piscinas têm áreas muito variadas, ocupando na área examinada menos de $2 \%$ do total.

\begin{tabular}{|c|c|c|c|c|}
\hline \multicolumn{3}{|c|}{ Moema: seis quadras com área total de $86400 \mathrm{~m}^{2}$} & $\mathrm{~m}^{2}$ & $\%$ \\
\hline \multirow{6}{*}{$\begin{array}{l}\text { Espaços Livres } \\
\left(55500 \mathrm{~m}^{2}=64,23 \%\right)\end{array}$} & \multirow{2}{*}{$\begin{array}{l}\text { Áreas de Lazer Contemplativo } \\
\left(9260 \mathrm{~m}^{2}=10,71 \%\right)\end{array}$} & Com Vegetação & 6000 & 6,94 \\
\hline & & Sem Vegetação & 3260 & 3,77 \\
\hline & \multirow[t]{2}{*}{$\begin{array}{l}\text { Áreas de Lazer Ativo } \\
\left(1600 \mathrm{~m}^{2}=1,84 \%\right)\end{array}$} & Recreação & 240 & 0,27 \\
\hline & & Esportes & 1360 & 1,57 \\
\hline & \multirow[t]{2}{*}{$\begin{array}{l}\text { Áreas de Circulação } \\
\left(44640 \mathrm{~m}^{2}=51,66 \%\right)\end{array}$} & Veículos & 27600 & 31,94 \\
\hline & & Pedestres & 17040 & 19,72 \\
\hline \multirow{2}{*}{$\begin{array}{l}\text { Espaços Ocupados } \\
\left(30900 \mathrm{~m}^{2}=35,76 \%\right)\end{array}$} & Construções Horizontais & Até quatro pavimentos & 16200 & 18,75 \\
\hline & Construções Verticais & Mais de quatro pavimentos & 14700 & 17,01 \\
\hline Total & & & 86400 & 100,00 \\
\hline
\end{tabular}

Quadro 2.6: Participação de cada tipo de área no total dos Espaços Livres de Moema.

Quanto à morfologia, os Espaços Livres nas propriedades privadas, geralmente são apenas os resultantes da aplicação dos índices da legislação e caracterizados pelos recuos. São significativas as áreas formadas pelos corredores laterais, os quais são retalhos, sobras dos lotes, inadequados para a maioria das atividades e com sérios problemas de conforto. 

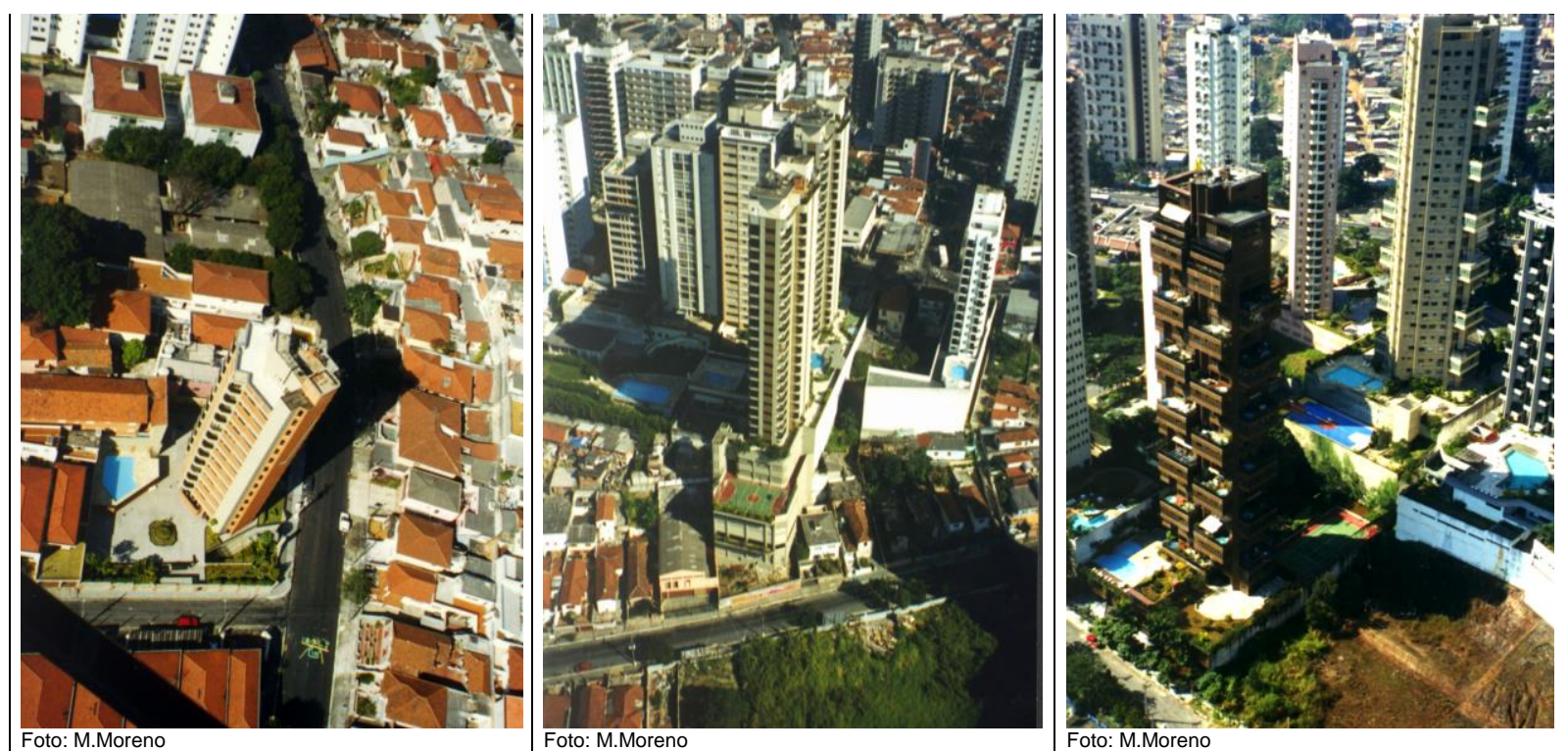

Figura 2-15: Implantações típicas. Considerando-se que as fotos foram tiradas às $12 \mathrm{~h}$ do dia 6 junho 98 (início do inverno), observa-se que todas as implantações têm problemas; na $1^{\mathrm{a}}$ o Playground está totalmente na sombra e na $2^{\mathrm{a}}$ e $3^{\mathrm{a}}$ o conjunto de edifícios formam sombras sobre os equipamentos das áreas livres.

O nível de adequação dos Espaços Livres às atividades neles desempenhadas é determinado examinando-se as características dos espaços, os principais usos, a infra-estrutura (instalações), as faixas etárias dos usuários, a freqüência de utilização e o grau de incômodo produzido nas outras pessoas. O quadro 2.7 mostra as interações entre as variáveis que indicam o nível de adequação dos Espaços Livres em termos espaciais e funcionais. A compatibilidade ambiental em termos de higiene do ar e climática é tratada no próximo item.

Em nossa análise, adotamos cinco faixas etárias: até 12 anos, crianças; de 13 a 18, adolescentes; entre 19 e 30 anos, jovens; de 31 a 60 anos, adultos; e acima de 61 anos, idosos ${ }^{38}$.

38 Em virtude do aumento da média de idades de nossa população, alteramos a denominação das pessoas entre 19 e 30 anos de adultos para jovens e a das pessoas entre 31 e 60 anos para adultos, ao invés de usar o termo meia idade, como aparece em: SAKATA, Francine Aramacho - As linhas projetuais da arquitetura paisagística no desenho dos espaços livres dos edifícios de apartamentos, São Paulo, Iniciação Científica FAUUSP, FAPESP, 1994. (p. 48 a 50). 


\begin{tabular}{|c|c|c|c|c|c|c|c|}
\hline \multirow{3}{*}{$\begin{array}{l}\text { Espaços } \\
\text { Livres }\end{array}$} & \multicolumn{7}{|c|}{ Adequação dos Espaços Livres em termos espaciais e funcionais } \\
\hline & \multirow{2}{*}{\begin{tabular}{|l} 
Atividades \\
Usos \\
\end{tabular}} & \multirow{2}{*}{\begin{tabular}{|l} 
Infra - Estrutura \\
Instalações
\end{tabular}} & \multirow[t]{2}{*}{ Faixas Etárias } & \multirow{2}{*}{$\begin{array}{l}\text { Freqüência de } \\
\text { uso semanal }\end{array}$} & \multicolumn{3}{|c|}{ Grau de Incômodo aos outros usuários } \\
\hline & & & & & Visual & Sonoro & Olfativo \\
\hline $\begin{array}{l}\text { Lazer } \\
\text { Contempla } \\
\text { tivo }\end{array}$ & $\begin{array}{l}\text { Repousar, } \\
\text { Ler, Olhar, } \\
\text { Conversar, } \\
\text { Piquenique, } \\
\text { Churrasco. }\end{array}$ & $\begin{array}{l}\text { Bancos, Mesas, } \\
\text { Perspectivas } \\
\text { Visuais } \\
\text { Churrasqueira, } \\
\text { Redes. }\end{array}$ & $\begin{array}{l}\text { Criança } \\
\text { Adolescente } \\
\text { Jovem } \\
\text { Adulto } \\
\text { Idoso }\end{array}$ & \begin{tabular}{|l|} 
Diariamente, \\
ao entardecer \\
Nos fins de \\
semana, o dia \\
todo.
\end{tabular} & $\begin{array}{l}\text { Geralmente } \\
\text { não interfere. }\end{array}$ & $\begin{array}{l}\text { Geralmente } \\
\text { não interfere, } \\
\text { gera pouco } \\
\text { ruído. }\end{array}$ & $\begin{array}{l}\text { A fumaça e } \\
\text { odores do } \\
\text { churrasco } \\
\text { costumam } \\
\text { incomodar. }\end{array}$ \\
\hline \multirow[t]{4}{*}{$\begin{array}{l}\text { Lazer Ativo } \\
\text { Recreação }\end{array}$} & \begin{tabular}{|l|} 
Pega Pega, \\
Amarelinha, \\
Roda, Pular \\
Corda, Jogar \\
Bola, Girar, \\
Escorregar, \\
Balançar, \\
Brincar na \\
areia e na \\
água. \\
\end{tabular} & $\begin{array}{l}\text { Áreas com } \\
\text { dimensões } \\
\text { superiores a 3m. } \\
\text { Gangorra, } \\
\text { Tanque de areia, } \\
\text { de água e outros } \\
\text { brinquedos } \\
\text { equipados. }\end{array}$ & Criança & \begin{tabular}{|l|} 
Diariamente, \\
nos horários \\
sem aulas. \\
Nos fins de \\
semana, o dia \\
todo.
\end{tabular} & $\begin{array}{l}\text { Muita agitação } \\
\text { atrapalha, a } \\
\text { paz e a } \\
\text { tranqüilidade. }\end{array}$ & $\begin{array}{l}\text { É fonte de } \\
\text { ruídos. }\end{array}$ & $\begin{array}{l}\text { Geralmente } \\
\text { não interfere. }\end{array}$ \\
\hline & $\begin{array}{l}\text { Capoeira, } \\
\text { Música e } \\
\text { Dança. }\end{array}$ & $\begin{array}{l}\text { Áreas com mais } \\
\text { de } 40 \mathrm{~m}^{2}\end{array}$ & $\begin{array}{l}\text { Criança } \\
\text { Adolescente } \\
\text { Jovem } \\
\text { Adulto } \\
\text { Idoso } \\
\end{array}$ & $\begin{array}{l}\text { Atividades } \\
\text { esporádicas. }\end{array}$ & $\begin{array}{l}\text { Atrapalha, a } \\
\text { paz e a } \\
\text { tranqüilidade. }\end{array}$ & $\begin{array}{l}\text { É fonte de } \\
\text { ruídos. }\end{array}$ & $\begin{array}{l}\text { Geralmente } \\
\text { não interfere. }\end{array}$ \\
\hline & $\begin{array}{l}\text { Patins, Skate, } \\
\text { Bicicleta. }\end{array}$ & $\begin{array}{l}\text { Caminhos com } \\
\text { largura acima } \\
3 \mathrm{~m} .\end{array}$ & $\begin{array}{l}\text { Adolescente } \\
\text { Jovem }\end{array}$ & \begin{tabular}{|l|} 
Diariamente, \\
horários sem \\
aulas.
\end{tabular} & $\begin{array}{l}\text { Atrapalha, a } \\
\text { paz e a } \\
\text { tranqüilidade. }\end{array}$ & $\begin{array}{l}\text { Gera algum } \\
\text { ruído. }\end{array}$ & $\begin{array}{l}\text { Geralmente } \\
\text { não interfere. }\end{array}$ \\
\hline & Malha, Bocha. & $\begin{array}{l}\text { Equipamentos } \\
\text { específicos. }\end{array}$ & \begin{tabular}{|l|} 
Adultos \\
Idosos
\end{tabular} & $\begin{array}{l}\text { Nos fins de } \\
\text { semana. }\end{array}$ & \begin{tabular}{|l} 
Pouca \\
Agitação.
\end{tabular} & $\begin{array}{l}\text { Gera algum } \\
\text { ruído. }\end{array}$ & $\begin{array}{l}\text { Geralmente } \\
\text { não interfere. }\end{array}$ \\
\hline \begin{tabular}{|l|} 
Lazer Ativo \\
Esportes
\end{tabular} & \begin{tabular}{|l|} 
Futebol, Tênis \\
e outros jogos \\
em Quadras, \\
Correr, \\
Caminhar, \\
Nadar, fazer \\
Ginástica.
\end{tabular} & $\begin{array}{l}\text { Quadra } \\
\text { Poliesportiva, } \\
\text { Piscina, Pista ou } \\
\text { caminho mais de } \\
\text { 3m de largura. }\end{array}$ & \begin{tabular}{|l|} 
Crianças \\
Adolescentes \\
Jovens \\
Adultos \\
Idosos
\end{tabular} & $\begin{array}{l}\text { Nos fins de } \\
\text { semana, o dia } \\
\text { todo. }\end{array}$ & $\begin{array}{l}\text { Atrapalha, a } \\
\text { paz e a } \\
\text { tranqüilidade. }\end{array}$ & $\begin{array}{l}\text { É fonte de } \\
\text { ruídos. }\end{array}$ & $\begin{array}{l}\text { Geralmente } \\
\text { não interfere. }\end{array}$ \\
\hline \begin{tabular}{|l|} 
Circulação \\
Pedestres
\end{tabular} & \begin{tabular}{|l|} 
Andar e \\
possibilitar \\
Acessibilidade \\
Universal.
\end{tabular} & \begin{tabular}{|l} 
Caminhos \\
regulares, sem \\
degraus e \\
declividades \\
inferiores a 6\%.
\end{tabular} & \begin{tabular}{|l|} 
Crianças \\
Adolescentes \\
Jovens \\
Adultos \\
Idosos
\end{tabular} & $\begin{array}{l}\text { Diariamente, } \\
\text { em qualquer } \\
\text { horário. }\end{array}$ & $\begin{array}{l}\text { Quando } \\
\text { intensa } \\
\text { atrapalha, a } \\
\text { paz e a } \\
\text { tranqüilidade. }\end{array}$ & $\begin{array}{l}\text { Sempre gera } \\
\text { algum ruído. }\end{array}$ & $\begin{array}{l}\text { Geralmente } \\
\text { não interfere. }\end{array}$ \\
\hline \begin{tabular}{|l} 
Circulação \\
Veículos
\end{tabular} & \begin{tabular}{|l} 
Circulação \\
estaciona \\
mento e \\
manobrabili- \\
dade de \\
automóveis.
\end{tabular} & $\begin{array}{l}\text { Eliminar conflitos } \\
\text { com a circulação } \\
\text { de pedestres }\end{array}$ & $\begin{array}{l}\text { Jovens } \\
\text { Adultos } \\
\text { ldosos }\end{array}$ & $\begin{array}{l}\text { Diariamente, } \\
\text { em qualquer } \\
\text { horário. }\end{array}$ & $\begin{array}{l}\text { Geralmente, o } \\
\text { fluxo de } \\
\text { veículos é } \\
\text { ameaçador }\end{array}$ & $\begin{array}{l}\text { É fonte de } \\
\text { ruídos } \\
\text { intensos. }\end{array}$ & $\begin{array}{l}\text { É fonte de } \\
\text { mau cheiro e } \\
\text { gases tóxicos. }\end{array}$ \\
\hline
\end{tabular}




\subsection{Normas Específicas sobre Variáveis Ambientais}

Como vimos no item 1.4, o conceito de Qualidade Ambiental está relacionado com o nível de satisfação que as pessoas obtém ao comparar as sensações percebidas do entorno, com suas expectativas, seus ideais e necessidades. Como as expectativas, os ideais e as necessidades mudam com o tempo, temos que trabalhar com diretrizes gerais de controle da qualidade ambiental, tais como normas e padrões de tolerabilidade ambiental, as quais, embora tenham que ser atualizadas freqüentemente, têm o mérito de identificar metas a serem alcançadas e estimular o debate sobre a qualidade do ambiente.

Em escala mundial, as preocupações com a Qualidade dos serviços ou a Qualidade da produção estiveram encabeçando as preocupações das organizações durante toda a década de 1980. No final dos anos 90, entre outras qualificações, uma empresa somente é considerada competitiva a nível mundial se tiver sido certificada como seguidora das normas da série ISO-9000, que trata da Gestão da Qualidade.

Os problemas e preocupações com o Ambiente, que já se arrastavam há várias décadas, como comprovam as conferências mundiais sobre meio ambiente realizadas em Estocolmo 1972 e Rio de Janeiro 1992, culminam com o estabelecimento das normas da série ISO-14000, que trata da Gestão Ambiental. No Brasil, essas normas foram traduzidas e oficializadas pela ABNT em outubro de 1996.

As empresas estão empenhadas em controlar os impactos de suas atividades, produtos ou serviços no meio ambiente, buscando contribuir para um desenvolvimento sustentável, esforçando-se para atender uma legislação cada vez mais exigente e aumentar sua competitividade, obtendo, além da certificação ISO9000 Gestão da Qualidade, também a certificação ISO-14000 Gestão Ambiental.

Apesar dessas importantes iniciativas de normatização no âmbito das empresas, que também abrangem padrões de qualidade dos ambientes internos, são muito raras as normas que tratem da qualidade nos Espaços Livres. Fizemos um levantamento na Associação Brasileira de Normas Técnicas visando uma atualização normativa, tendo como referência os tópicos abordados em nossas análises e o resultado confirma que o pouco existente procura normatizar principalmente os ambientes internos. O resultado do levantamento nos itens de Higiene Ambiental e nos itens Climáticos, é o seguinte: 


\subsubsection{Higiene Ambiental}

Iluminação: As normas brasileiras que tratam de níveis de iluminância para diversas atividades são: a NBR5382/85 (orig. MB207): Verificação de iluminância de interiores e a NBR 5413/92 (orig. NB57): Iluminância de Interiores, que embora estabeleça referências para iluminação artificial em ambientes internos, serve também como fonte de parâmetros para iluminação natural. As iluminâncias mínimas, indicadas pelas normas, para as principais atividades desempenhadas nos espaços livres são: Circulação em geral: 100 lux; Recreação: 150 lux; Esportes: 200 lux; Leitura: 300lux. Nos espaços livres, o céu e as características de reflexão do entorno são as fontes de luz, portanto, a iluminação depende: da porcentagem da área do céu que está desobstruída, das condições de luminosidade do céu e da reflexão das superfícies ao redor.

Ruídos: As normas que tratam sobre níveis sonoros, os valores de intensidade aceitáveis e formas de atenuá-los são: NBR10152/87 (orig. NB95): Níveis de ruído para conforto acústico; NBR10151/2000 (orig. NB1095): Acústica - avaliação do ruído em áreas habitadas, visando o conforto da comunidade - procedimentos; NBR7731/83 (orig. NB616): Guia para execução de serviços de medição de ruído aéreo e avaliação dos efeitos sobre o homem; NBR14313/99: Barreiras acústicas para vias de tráfego - características construtivas; NBR12540/92: Grandezas e unidades de acústica, e TB143/73: Poluição sonora. A portaria 92/80 do Ministério do Interior dispõe sobre a emissão de sons e ruídos em decorrência de quaisquer atividades industriais, comerciais, sociais ou recreativas; no parágrafo II consta "Consideram-se prejudiciais à saúde, à segurança e ao sossego público, para os fins do item anterior, os sons e ruídos que:" e prossegue no item b "independentemente do ruído de fundo, atinjam no ambiente exterior do recinto em que têm origem, mais de 70 (setenta) decibels - $d B(A)$, durante o dia, e 60 (sessenta) decibels - $d B(A)$, durante a noite;".

Os ruídos urbanos são originados pelas atividades humanas, de três fontes principais: os transportes, a produção e o terciário. Nas áreas livres predominam os ruídos gerados por veículos de transportes, tais como: automóveis, caminhões, ônibus, motocicletas, trens e aviões; pelos meios de produção, pois embora as grandes fábricas barulhentas tenham saído da cidade de São Paulo, outras atividades produtivas, como a indústria da construção civil, em várias de suas etapas 
é fonte de ruídos, a exemplo das britadeiras, dos bate-estacas, tratores, betoneiras e compressores; e os ruídos produzidos por estabelecimentos do setor terciário como: clubes esportivos, escolas, casas de diversão, bares e lanchonetes.

Quando possível, o ideal é que os problemas acústicos sejam resolvidos ou atenuados na fonte, em parte isso ocorre com a renovação da frota, já que os veículos, as máquinas e os novos equipamentos são mais silenciosos que os antigos, porém, nas grandes cidades o resultado não é significativo porque a multiplicação das fontes é constante. O incômodo sonoro depende de vários fatores, como a intermitência e a freqüência, porém, a intensidade é a referência mais importante, recomendando-se que uma sala de leitura quieta não exceda $30 \mathrm{~dB}(\mathrm{~A})$, que restaurantes ou escritórios calmos cheguem no máximo a $40 \mathrm{~dB}(\mathrm{~A})$ e que uma oficina só seja considerada tranqüila se tiver menos de $50 \mathrm{~dB}(\mathrm{~A})$.

Odores: A pesquisa na ABNT, procurando alguma norma referente a níveis aceitáveis de odores ou cheiros no ar, nada obteve; as normas correlatas são NBR14341/99: Água - Determinação de odor - Método de análise sensorial e NBR9417/86 (orig. MB2385): Solventes orgânicos - Verificação do odor, as quais não tem uma aplicação direta na avaliação dos cheiros urbanos. Apesar dessa lacuna, os odores urbanos dos veículos, dos rios, das galerias de esgotos e do lixo em decomposição, são problemas de qualidade ambiental que carecem soluções. Somos sensíveis a inúmeras substâncias desde que voláteis, isto é, para sensibilizar nosso olfato o material tem que estar em forma gasosa. Dentre as várias substâncias, somos mais sensíveis aos compostos orgânicos e dentre eles mais ainda aos hidrocarbonetos. Neste item, a intuição foi o critério de avaliação, não fizemos medições, usamos como parâmetros o grau de incômodo causado aos pesquisadores.

Poluição do Ar: A Higiene Atmosférica está prejudicada quando as quantidades normais dos gases componentes do $a^{39}$ estão alteradas, ou contém outros gases, ou têm substâncias vaporizadas, ou quando há material particulado flutuando no ar. A portaria 231/76 do Ministério do Interior por sugestão da Secretaria Especial do Meio Ambiente-SEMA estabelece os padrões de qualidade do $\operatorname{Ar}$ e a norma

\footnotetext{
${ }^{39} \mathrm{~A}$ composição do ar a $25^{\circ} \mathrm{C}$ e pressão de $760 \mathrm{~mm}$ de $\mathrm{Hg}$ (uma atmosfera) é em volume: $78,09 \%$ Nitrogênio, 20,94\% Oxigênio, 0,93\% Argônio, 0,03\% Gás Carbônico e 0,001\% Hidrogênio.
} 
NBR8969/85 (orig. TB144): Poluição do ar, define os termos empregados nos estudos de poluição do ar.

Gases: A portaria 231/76 do Minter-SEMA estabelece padrões de qualidade, definindo os valores máximos admissíveis para os seguintes gases: Dióxido de Enxofre $\left(\mathrm{SO}_{2}\right)$ concentração média anual de 80 microgramas por metro cúbico e concentração máxima diária de 365 microgramas por metro cúbico, não devendo ser excedida mais de uma vez por ano; Monóxido de Carbono (CO) concentração máxima de 8 horas de 10.000 microgramas por metro cúbico, não devendo ser excedida mais de uma vez por ano e uma concentração máxima horária de 40.000 microgramas por metro cúbico, que não deve ser excedida mais de uma vez por ano; Oxidantes Fotoquímicos, como por exemplo, o Ozônio $\left(\mathrm{O}_{3}\right)$ ou Óxidos de Nitrogênio, concentração máxima horária de 160 microgramas por metro cúbico, que não deve ser excedida mais de uma vez por ano.

As normas que tratam dos métodos de medição das quantidades de gases na atmosfera são: NBR12979/93 Atmosfera: determinação da concentração de dióxido de enxofre, pelo método do peróxido de hidrogênio; NBR13157/94 Atmosfera: Determinação da concentração de monóxido de carbono por espectrofotometria de infravermelho não dispersivo; e NBR8833/83 (orig. NB830): Determinação de conformidade de veículos leves com os padrões estabelecidos para emissão de escapamento.

Partículas em Suspensão: Conforme a portaria 231/76 do Minter-SEMA os valores máximos admissíveis são: concentração média anual de 80 microgramas por metro cúbico, e uma concentração máxima diária de 240 microgramas por metro cúbico, que não deve ser excedida mais de uma vez por ano.

As normas que tratam dos métodos de medição das quantidades de material particulado na atmosfera são: NBR12065/91 (orig. MB3402) Atmosfera: Determinação da taxa de poeira sedimentável total; NBR13412/95: Material particulado em suspensão na atmosfera - Determinação de partículas inaláveis; e NBR9547/97 (orig. MB2172) Material particulado em suspensão no ar ambiente Determinação de concentração total.

\subsubsection{Clima:}

Na ABNT há normas sobre climatização de espaços internos, principalmente de ar condicionado, como a NBR6401/80 (orig. NB10): Instalações centrais de ar 
condicionado para conforto - parâmetros básicos de projeto e a NBR6675/93 (orig. NB291): Instalações de condicionadores de ar de uso doméstico, que citam os referenciais microclimáticos desejáveis quanto à temperatura e umidade do ar em ambientes climatizados; esses parâmetros são muito estreitos, para os espaços livres externos nos quais a adaptabilidade das pessoas é maior, seja porque há maior grau de atividade física ou porque se pode usar roupas mais pesadas, inadmissíveis em espaços internos.

A ISO International Organization for Standardization adotou os estudos de P. O. FANGER na norma ISO7730/84: Moderate thermal environments - Determination of the PMV and PPD index and specification of the conditions for thermal comfort, tratase de uma equação que combina as variáveis climáticas: temperatura do ar, velocidade do ar, umidade relativa e temperatura radiante média, com variáveis pessoais como tipo de atividade física e o grau de resistência térmica da vestimenta. A partir de experimentos, Fanger obteve com sua equação, para diversas condições ambientais o PMV: Predicted Mean Vote (voto médio estimado), que é um número representativo da aclimatação humana, sendo que para Conforto o PMV é zero, para Frio é negativo e para Calor é positivo. O índice PPD: Predicted Percentage of Dissatisfied (percentagem de pessoas desconfortáveis) apresenta o percentual de pessoas que se sentiriam desconfortáveis, segundo a norma ISO7730/84 considerase que as condições são adequadas se o PPD ficar abaixo de $20 \%$. 


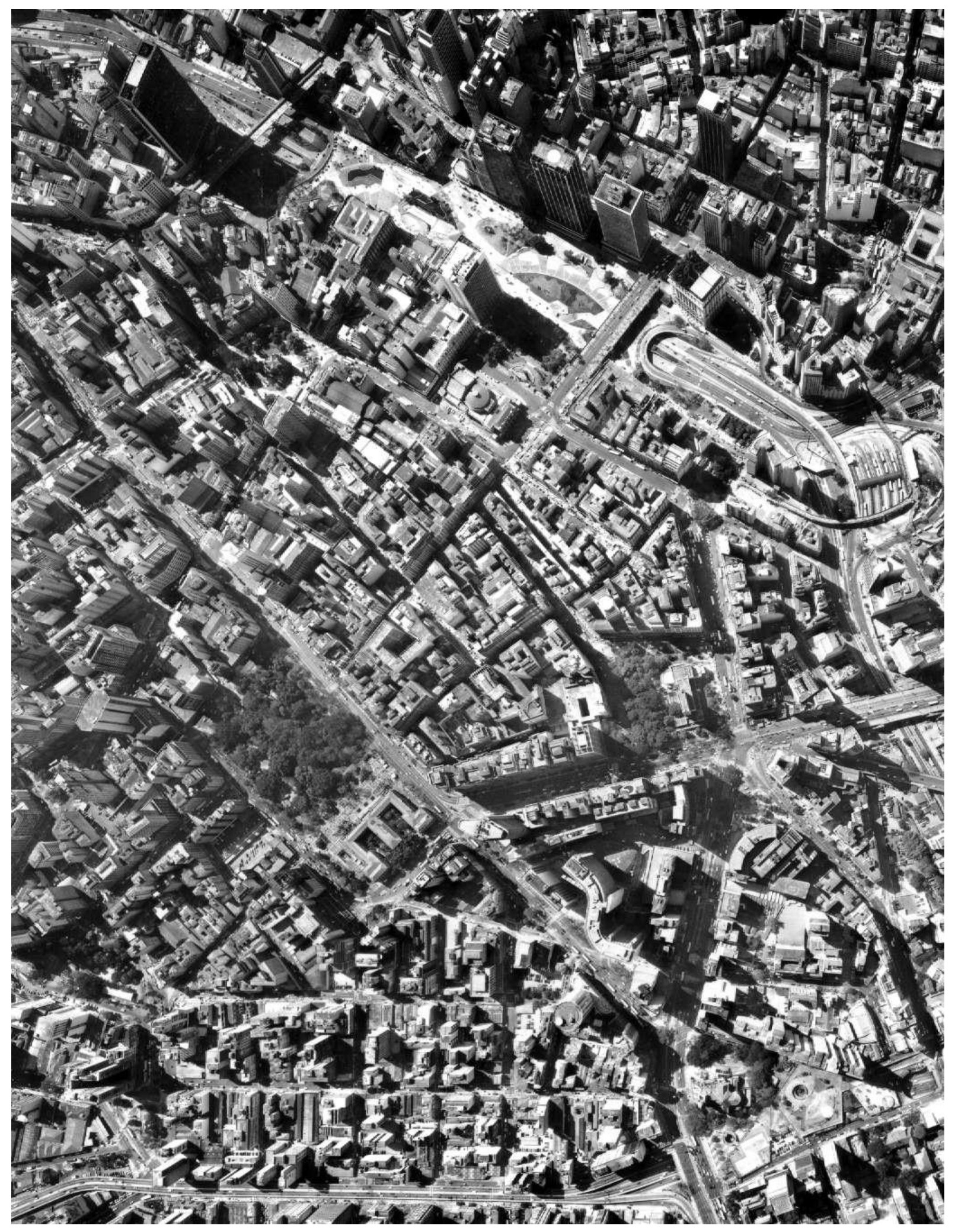

Fonte: BASE aerofogrametria S.A.

Figura 2-16: Foto aérea mostrando o centro da Cidade de São Paulo, a praça da República, os edifícios Copan e Itália e o vale do Anhangabaú. Esta imagem caracteriza a verticalização da primeira metade do século XX. 



\section{Caracterização Ambiental da Cidade de São Paulo}

\subsection{Conceituações para a Caracterização Ambiental}

A Caracterização Ambiental de uma cidade é determinada pela descrição dos elementos que compõem o ambiente, como interagem entre si e com as estruturas criadas pela sociedade.

Dentre os componentes dos ecossistemas (ar, água, solo, energia solar, vegetação e fauna), as análises são feitas a partir das interações entre a energia solar e o ar, que são os condicionantes do meio ambiente em que vivemos imersos e que no item 1.9.2 desdobramos em Higiene Ambiental e Clima.

Esse meio ambiente "Atmosférico", atua sobre um suporte Morfológico formado por todos os outros componentes do ecossistema: água, solo, vegetação e fauna. Caracterizar a Ambiência da Cidade de São Paulo implica em examinar a Higiene Ambiental, o Clima e também a Morfologia, tanto a Natural que é geomorfológica, quanto a Urbana que é a morfologia produzida pelas ações antrópicas. Conceitualmente, adotamos como critério, expor as características ambientais em uma seqüência que vai da maior abrangência e menor possibilidade de controle pelo ser humano, por exemplo o sistema solar, a partir do qual se origina a iluminação, a insolação e todas as fontes de energia na Terra; até a escala do indivíduo, como por exemplo em suas relações com um piso ao caminhar.

\begin{tabular}{|c|c|c|c|c|}
\hline \multirow[b]{2}{*}{ Abrangências } & \multicolumn{4}{|c|}{ Características Ambientais } \\
\hline & $\begin{array}{c}\text { Morfológicas } \\
\text { Naturais }\end{array}$ & $\begin{array}{c}\text { Morfológicas } \\
\text { Urbanas }\end{array}$ & $\begin{array}{c}\text { de Higiene } \\
\text { Ambiental do Ar }\end{array}$ & Climáticas \\
\hline 12. Sistema Solar & Iluminação (Luz) & & & Insolação (Calor) \\
\hline 11. Mundo, Terra & Fontes de Energia & & & \\
\hline 10. Continente & $\begin{array}{l}\text { Correntes } \\
\text { Atmosféricas }\end{array}$ & & & \\
\hline 9. Nação & Continentalidade & & & \\
\hline 8. Região & Relevo & & & Clima \\
\hline 7. Metrópole & Bacias, Ventos & $\begin{array}{l}\text { Área Urbanizada, } \\
\text { Corpos d'água }\end{array}$ & & $\begin{array}{l}\text { llhas de Calor, } \\
\text { Inversões térmicas }\end{array}$ \\
\hline 6. Cidade & Forma do Relevo & $\begin{array}{l}\text { Tipos Urbanização, } \\
\text { Vegetação }\end{array}$ & Calor & $\begin{array}{l}\text { Umidade, } \\
\text { Precipitações }\end{array}$ \\
\hline 5. Zona & Drenagem & Permeabilidade & & Temperaturas \\
\hline $\begin{array}{l}\text { 4. Vizinhança, } \\
\text { Bairro }\end{array}$ & Áreas de risco & \begin{tabular}{|l} 
Erosões, \\
Instabilidades
\end{tabular} & $\begin{array}{l}\text { Gases, Fumaça, } \\
\text { Poeiras }\end{array}$ & Ventos \\
\hline 3. Rua & & Arruamentos & Lixo, Sujeira & \\
\hline 2. Lar, Parcela & & $\begin{array}{l}\text { Verticalização, } \\
\text { Loteamento }\end{array}$ & Luz, Ruído, Odores & Microclima \\
\hline 1. Indivíduo & & $\begin{array}{l}\text { Ergonomia/ } \\
\text { Cinestesia }\end{array}$ & & \\
\hline
\end{tabular}

Tabela 3-1: Abrangências das Características Ambientais. (fonte: Elaboração do autor com dados de John Lyle e American Institute of Architects) 
John Tilman Lyle ${ }^{40}$ apresenta uma seqüência de escalas de abordagem adotada pelo "Urban Design Committee of the American Institute of Architects" que, em doze estágios, vai do indivíduo ao sistema solar. A partir dessa seqüência, desenvolvemos o quadro 3.1, onde cada característica ambiental é classificada por sua escala de abrangência.

\subsubsection{Conceituação das Características Morfológicas Naturais}

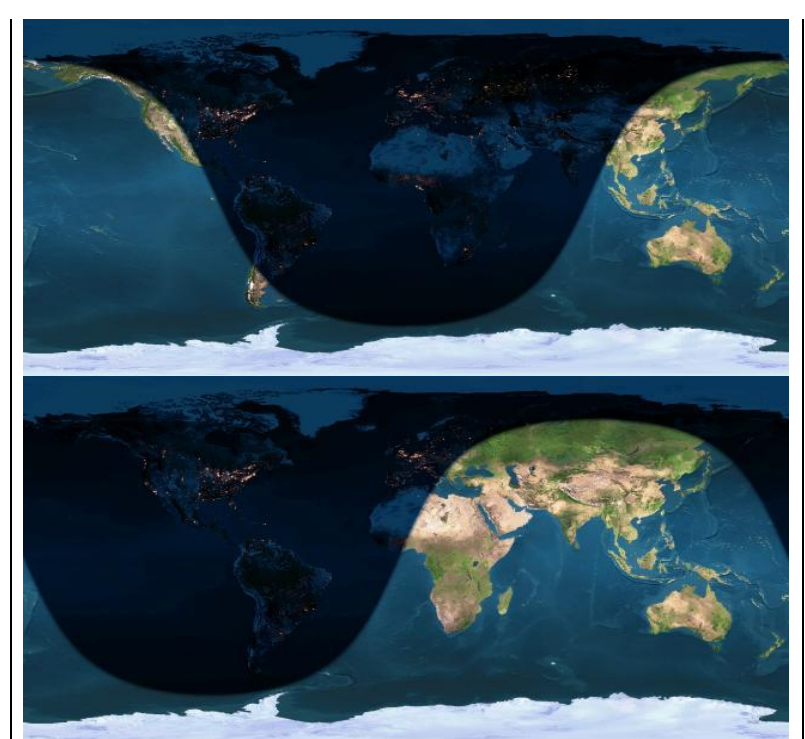

3.1.1.1 LUZ

As quantidades de Luz e Calor que incidem numa região são determinadas pelos movimentos de translação e rotação da Terra em torno do Sol, pela posição da cidade (latitude e altitude) no planeta, pelas condições de transparência atmosférica determinadas pelos teores de poluição e ou umidade no ar e também pelo grau de reflexão do entorno, que depende da cor e tipo de

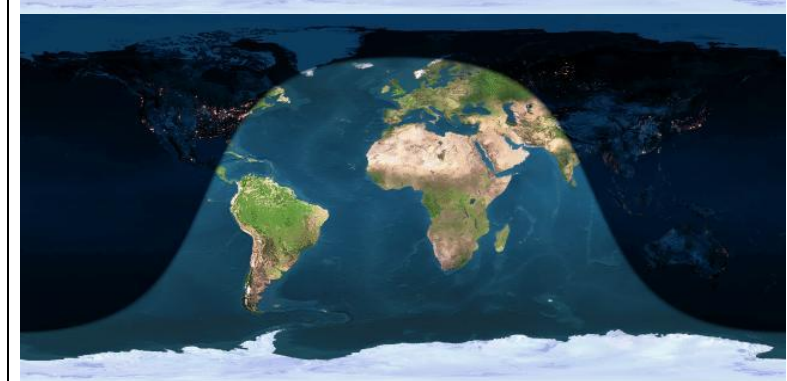
material das superfícies. Para efeito de iluminação, trabalha-se com a luz difusa do céu, deixando-se as trajetórias do Sol para estudos de insolação e estimativas do calor recebido.

\subsubsection{Fontes de Energia}

Todas as Fontes ${ }^{41}$ de energia utilizadas pela humanidade são derivadas, direta ou indiretamente, da radiação Solar que chega ou que chegou na Terra. Para

Figura 3-1: As imagens mostram a radiação solar incidindo sobre a Terra às $0 \mathrm{~h}, 6 \mathrm{~h}, 12 \mathrm{~h} \mathrm{e}$ 18h (GMT) do dia 31dez2000.

exemplificar, podemos citar as seguintes fontes: Muscular, Lenha, Moinho de Vento, Roda d’água, Gás Natural, Petróleo, Carvão Mineral, Álcool, Biogás, Solar direta, etc... .

\footnotetext{
40 LYLE, John Tillman-Design for Human Ecosystens, @ 1985, New York, Van Nostrand Reinhold Company p.41

${ }^{41}$ Entendemos Fonte qualquer material ou sistema em condições de vir a produzir energia, isto é, eles têm energia potencial.
} 
Em uma situação ecológica natural, de toda a energia solar que chega na Terra, uma parte flui na cadeia alimentar, sobe através da atmosfera, embutida no vapor d'água e volta ao espaço como infravermelho, enquanto outra parte após passar pela cadeia alimentar fica hibernando, como ocorre com os combustíveis fósseis. Tudo isso mantém o planeta em equilíbrio energético, a energia que entra no sistema é igual a que sai. A partir dos séculos XIX e XX, com o incremento das atividades industriais e o uso intensivo dos combustíveis fósseis, uma parte da energia que estava hibernando é liberada, causando o aumento do teor de gás carbônico na atmosfera, o efeito estufa, e as ilhas de calor.

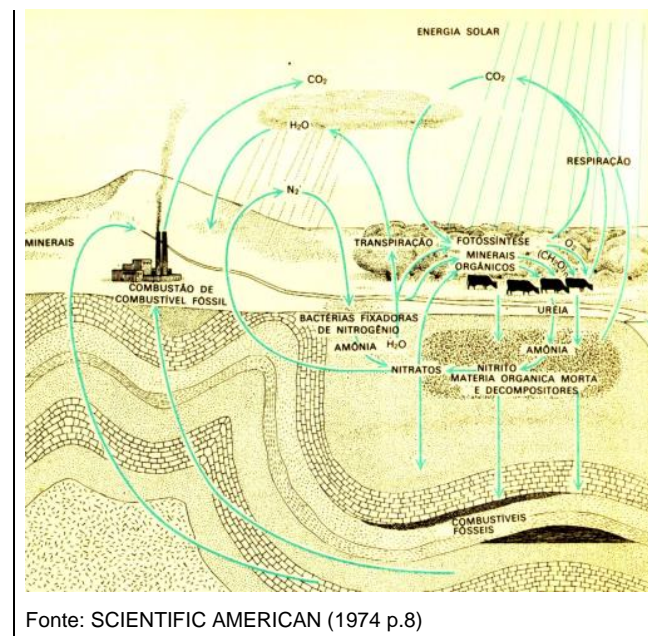

Figura 3-2: Ciclo de Energia e de Gás Carbônico.

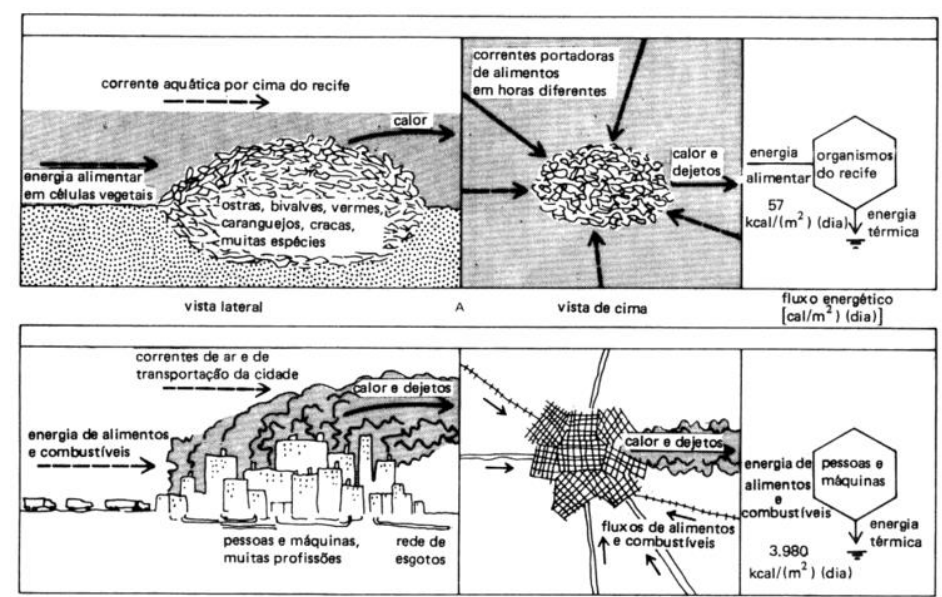

Fonte: ODUM (1988 p.46)

Figura 3-3:Fluxos de energia semelhantes; em um recife de ostras e numa cidade. Em ambos entram energias e alimentos; e saem dejetos e calor.

\subsubsection{Correntes Atmosféricas}

A radiação solar aquece a atmosfera de maneira diferenciada em função da latitude; mais quente no Equador e mais fria junto aos Pólos. Como o ar frio é mais denso do que o ar quente, originam-se diferenças de pressão que associadas com a rotação da Terra produzem a circulação mundial dos ventos. De maneira geral, temos três tipos de Correntes Atmosféricas: os ventos Alísios entre as latitudes $30^{\circ} \mathrm{N}$ e $30^{\circ} \mathrm{S}$ que são fracos; os ventos Oeste entre $30^{\circ}$ e $60^{\circ}$ tanto $\mathrm{N}$ como $\mathrm{S}$ que são rápidos e os ventos polares em latitudes de $60^{\circ}$ até os pólos tanto $\mathrm{N}$ como $\mathrm{S}$, que são tempestuosos. Os ventos que predominam no Brasil são os Alísios que

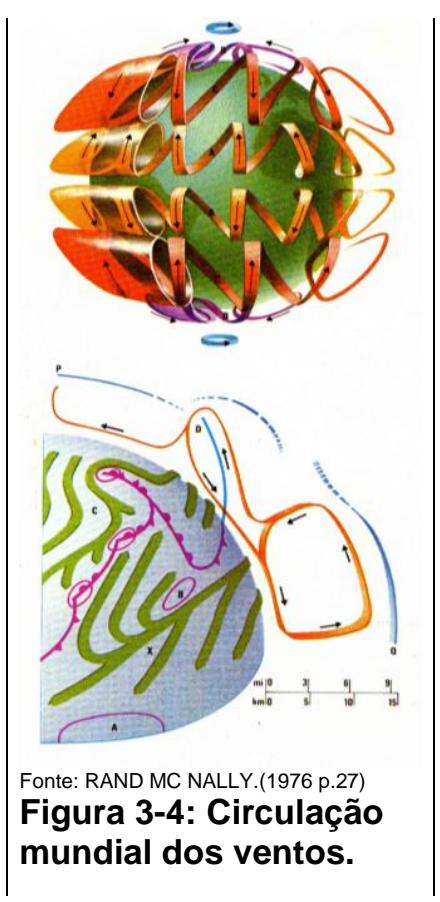
sopram de Sudeste. 


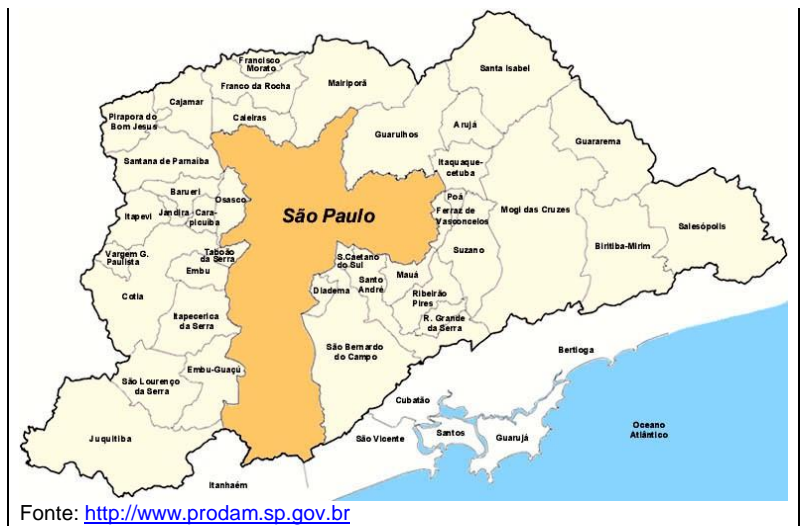

Figura 3-5: A Grande São Paulo, apesar de ficar no planalto, recebe, pela proximidade, influência dos ventos do oceano Atlântico.

\subsubsection{Continentalidade}

Os oceanos têm comportamentos físicos diferentes dos continentes; a água tem calor específico maior que a terra e demora mais para se aquecer e para se esfriar do que o solo. Por isso, a distância de uma cidade aos corpos d'água, tanto dos mares, como de grandes lagos, represas ou rios; associada às condições de relevo, altera

os ventos, umidades e temperaturas e, portanto, do clima local. Geralmente, quanto mais próximo da água, maior é a umidade e quanto mais úmida uma região, menos oscilam as temperaturas, tendo-se menores variações térmicas, tanto sazonais quanto diuturnas.

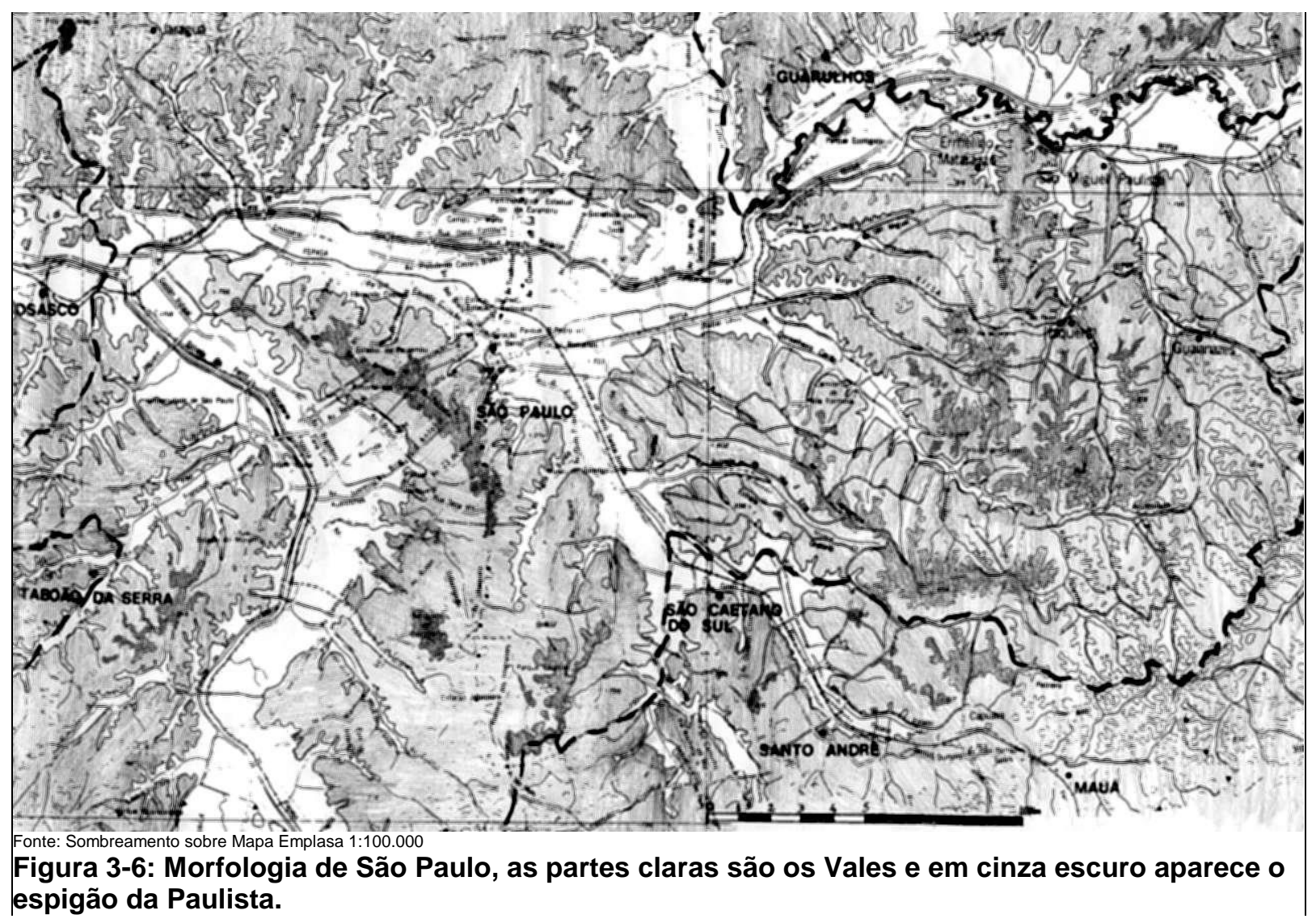

\subsubsection{Formas do Relevo}

A movimentação topográfica determina as cotas, as declividades, a orientação das vertentes, os divisores de águas e as bacias, com seus vales e corpos d'água; por isso, o relevo é uma das mais fortes características ambientais. Dependendo das

54 Qualidade Ambiental nos Espaços Livres de Areas Verticalizadas da Cidade de São Paulo MORENO, Manuel Francisco Navarro 
características geomorfológicas de uma área podem-se alterar: a insolação absorvida, a direção dos ventos, a capacidade de dispersar os poluentes, a umidade atmosférica, a drenagem, as áreas inundáveis, a estabilidade das encostas e o clima local.

\subsubsection{Bacias}

Os vales são unidades morfológicas que condicionam a circulação dos fluidos, tanto da água dos rios, quanto dos ventos nas camadas mais baixas. A orientação da bacia induz a insolação em suas encostas; com muito sol, de manhã, nas vertentes leste e muito sol, à tarde, nas vertentes oeste. Se o local estiver abaixo da linha do Equador, o lado sul receberá muita insolação no verão, enquanto o lado norte terá insolação no inverno.

\subsubsection{Drenagem}

A capacidade drenante de uma área depende das características de sua declividade, do nível do lençol freático e da permeabilidade do solo.

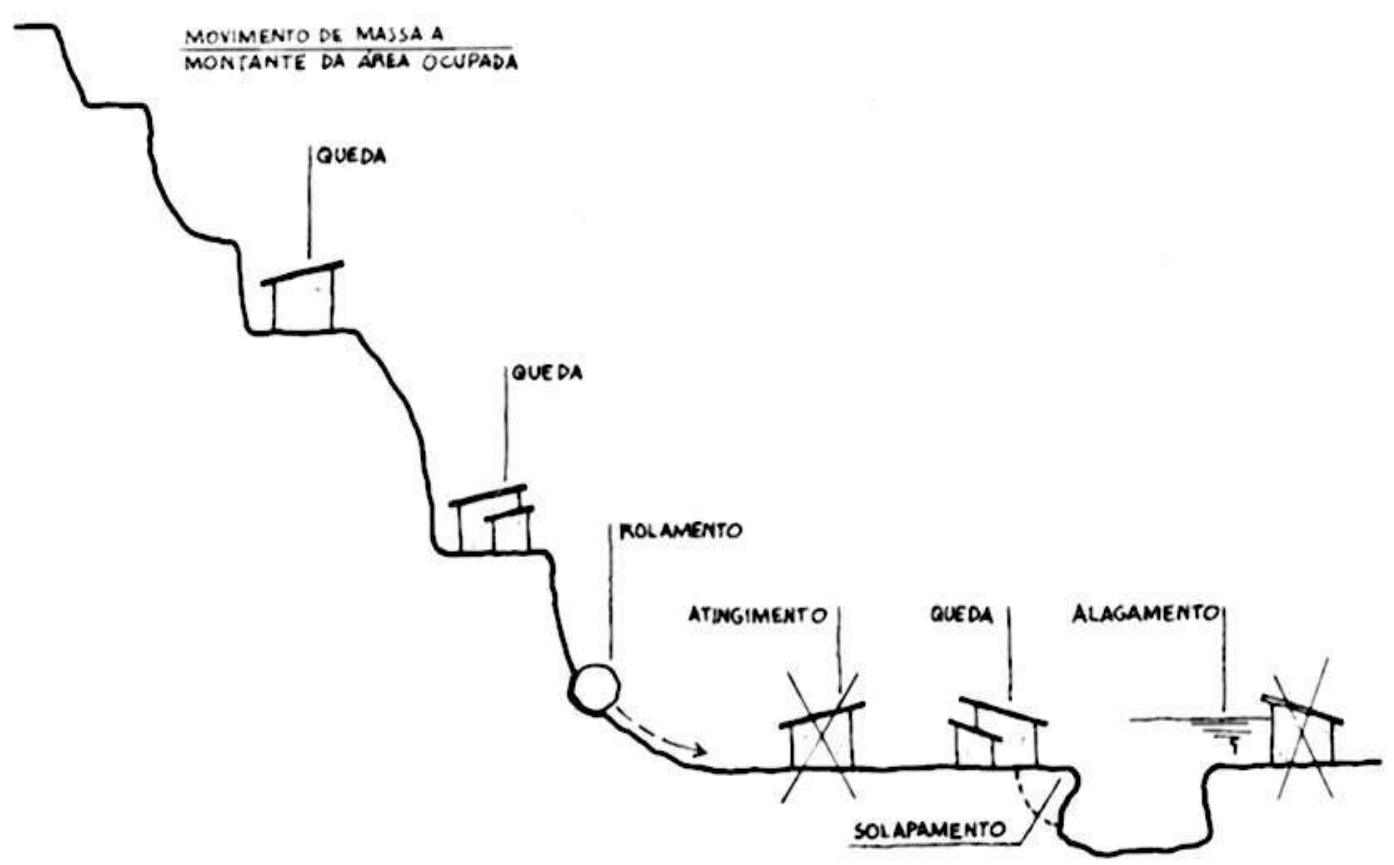

Situaçōes de risco (Fonte: "Hierarquização de situaçōes de risco em favelas no município de São Paulo, Brasil - Critérios e Metodologia", Leandro E. Silva Cerri e Celso Santos Carvalho.)

Figura 3-7: Tipologias de ocorrências em áreas de risco. 


\subsubsection{8 Áreas de risco}

Solos como os siltes e as argilas, em áreas de maior declividade, estão sujeitos a desmoronamentos pela ação das intempéries (ver fig. 3-7).

\subsubsection{Conceituação das Características Morfológicas Urbanas}

\subsubsection{Urbanização}

As cidades e mais ainda as metrópoles, são as ações humanas que causam os maiores impactos sobre o meio natural, talvez somente algumas atividades de mineração, que literalmente removem montanhas, causem alterações maiores na natureza. Em termos ecológicos, o solo tem o papel de sustentar e nutrir os vegetais e, conseqüentemente, a cadeia alimentar, viabilizando um ciclo contínuo de nutrientes. Os arruamentos e as construções recobrem o solo bloqueando e impedindo esse ciclo. Todos os ciclos biogeoquímicos dos ecossistemas são alterados. Por exemplo, com relação ao ciclo hidrológico, temos que as grandes áreas urbanas tendem a ser mais secas; no ciclo de energia solar constata-se que as cidades são mais quentes que as

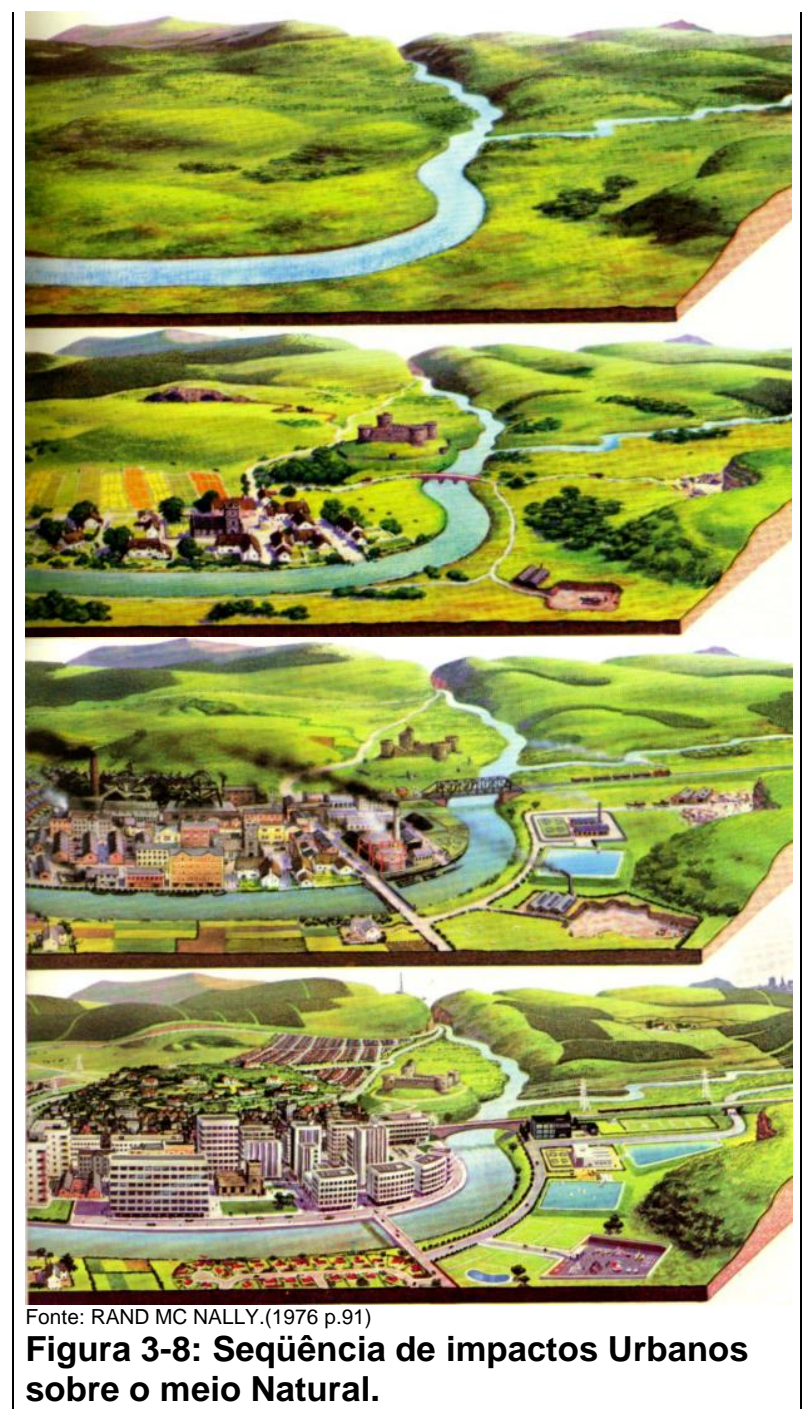
sobre o meio Natural.

áreas circunvizinhas; quanto ao ciclo do gás carbônico, nas áreas urbanas, as quantidades tendem a aumentar continuamente. Com maior ou menor impacto também ocorrem alterações em todos os outros ciclos.

A urbanização é intervenção humana de grande impacto ambiental. Aspectos ambientais, culturais, econômicos e tecnológicos, definem a configuração do tecido urbano, ditando as tipologias de urbanização. O nível de urbanização, sua abrangência, densidade, o grau de verticalização, a distribuição dos setores de atividades, os sistemas de transportes, as propriedades dos materiais, cores e proporção entre espaços construídos e massa arbórea, determinam o balanço 
energético. Isto é, o fluxo de energia solar que entra é função da absorção e reflexão (albedo) das superfícies; o tempo de retenção da energia depende do calor específico dos materiais (inércia térmica), enquanto a saída energética é conseqüência do albedo e da emitância das superfícies.

\subsubsection{Corpos D’Água}

Dentre as características ambientais relevantes produzidas pelas intervenções humanas temos as grandes superfícies de água originadas pelas represas. Como a água tem calor específico alto, isto é, demora para se aquecer e demora a esfriar, de dia geralmente as massas de água estão frias mantendo o ar que está em contato também frio e denso, portanto, durante o dia temos bolsões de ar frio sobre as represas; é esse o ar denso e lento que se desloca seguindo o caminho dos vales. À noite, geralmente é o solo que está mais frio e também o ar sobre ele, agora as

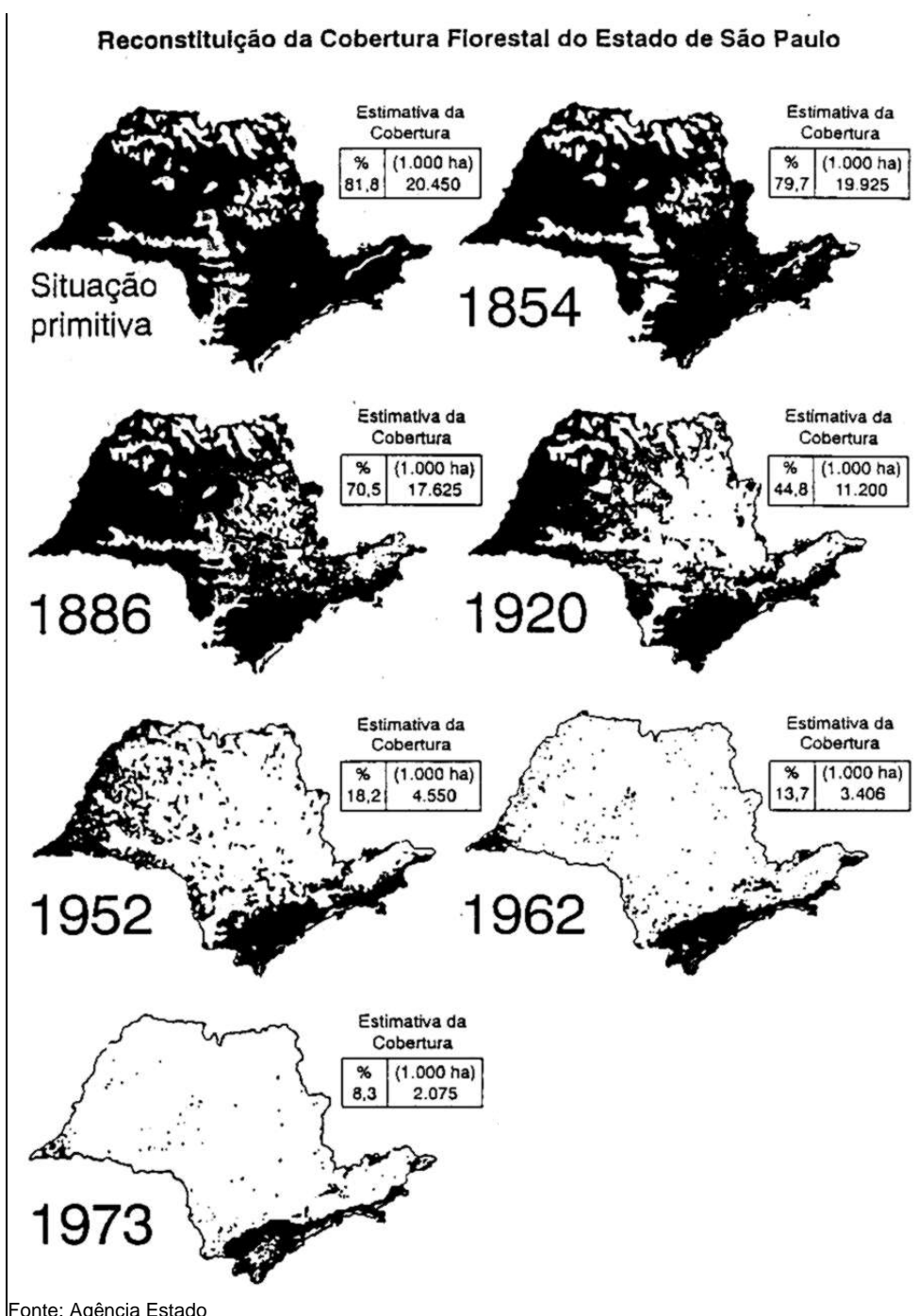

Figura 3-9: Regressão das áreas florestadas no Estado de São Paulo. massas de ar fluem do solo em direção aos corpos d'água.

\subsubsection{Vegetação}

Historicamente, no Brasil, a mata original de uma área sempre foi considerada como obstáculo ao processo de urbanização.

$\mathrm{Na}$ escala do Estado de São Paulo, os levantamentos mostram que restam apenas $3 \%$ das matas originais que recobriam o Estado. E a vegetação continua perdendo para os empreendimentos e atividades humanas, às vezes, até de maneira indireta, como ocorre, por exemplo, com a Serra do Mar onde a vegetação está sendo 
atacada, corroída, pelos ventos impregnados de poluentes secundários tipo chuva ácida liberados em Cubatão.

\subsubsection{Permeabilidade}

Assim como a cidade recobre o solo impedindo-o em sua função de nutrir os vegetais, também impermeabiliza grandes áreas provocando inundações nas várzeas, nos períodos das chuvas. A urbanização reduz e em algumas áreas elimina a permeabilidade do solo.

\subsubsection{Erosões e Instabilidades}

Outra característica ambiental decorrente dos processos antrópicos, tanto urbanos como rurais, é o aumento das áreas de risco onde podem ocorrer

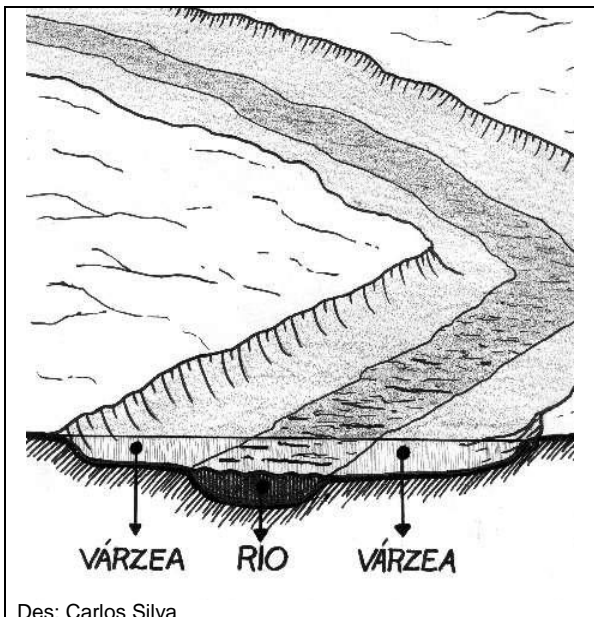

Des: Carlos Silva

Figura 3-10: A várzea normal é inundável e passa a ser um risco para a urbanização que a invade.

erosões e desmoronamentos pela ação das intempéries sobre os solos mais plásticos e erodíveis, agravadas por desmatamentos, movimentos de terra ou ocupações em áreas de grande declividade, aumentando as probabilidades de deslizamentos de encostas.

\subsubsection{Arruamentos e Verticalização}

As ruas, com as seqüências de edificações altas, criam desfiladeiros que prejudicam a iluminação, reverberam os sons, alteram a circulação dos ventos, modificam insolação, concentram poluição, entre outras. verticalização produz outra morfologia; edificações

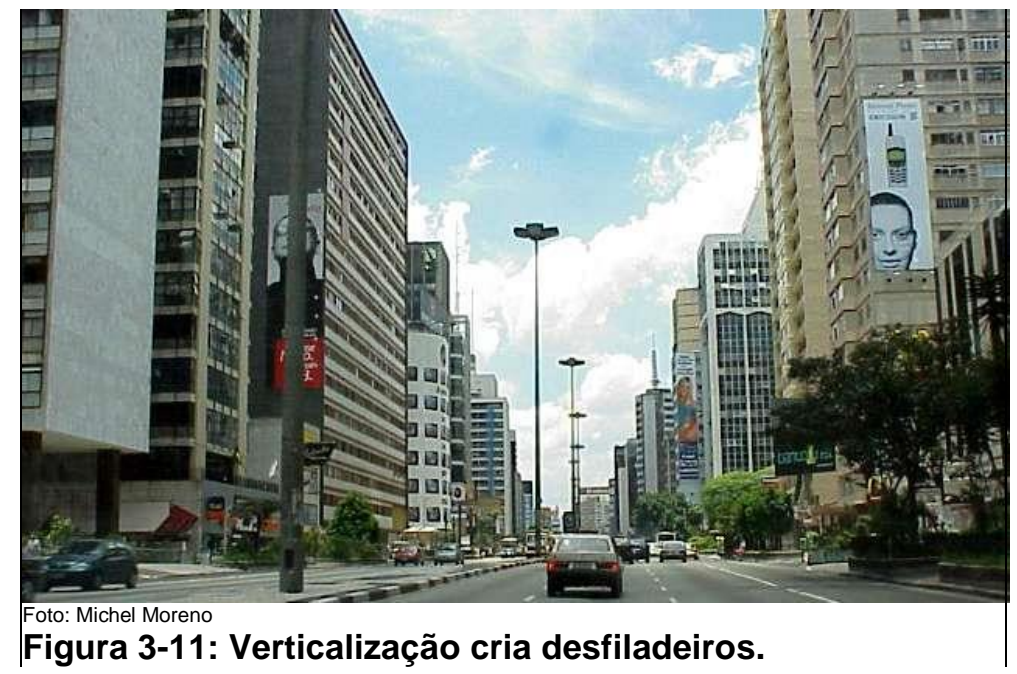
sobrepõem-se à superfície original; à topografia de embasamento agregam-se trinta, cinqüenta, cem metros de edificações que alteram o perfil morfológico pré-existente. 


\subsubsection{Ergonomia e Cinestesia}

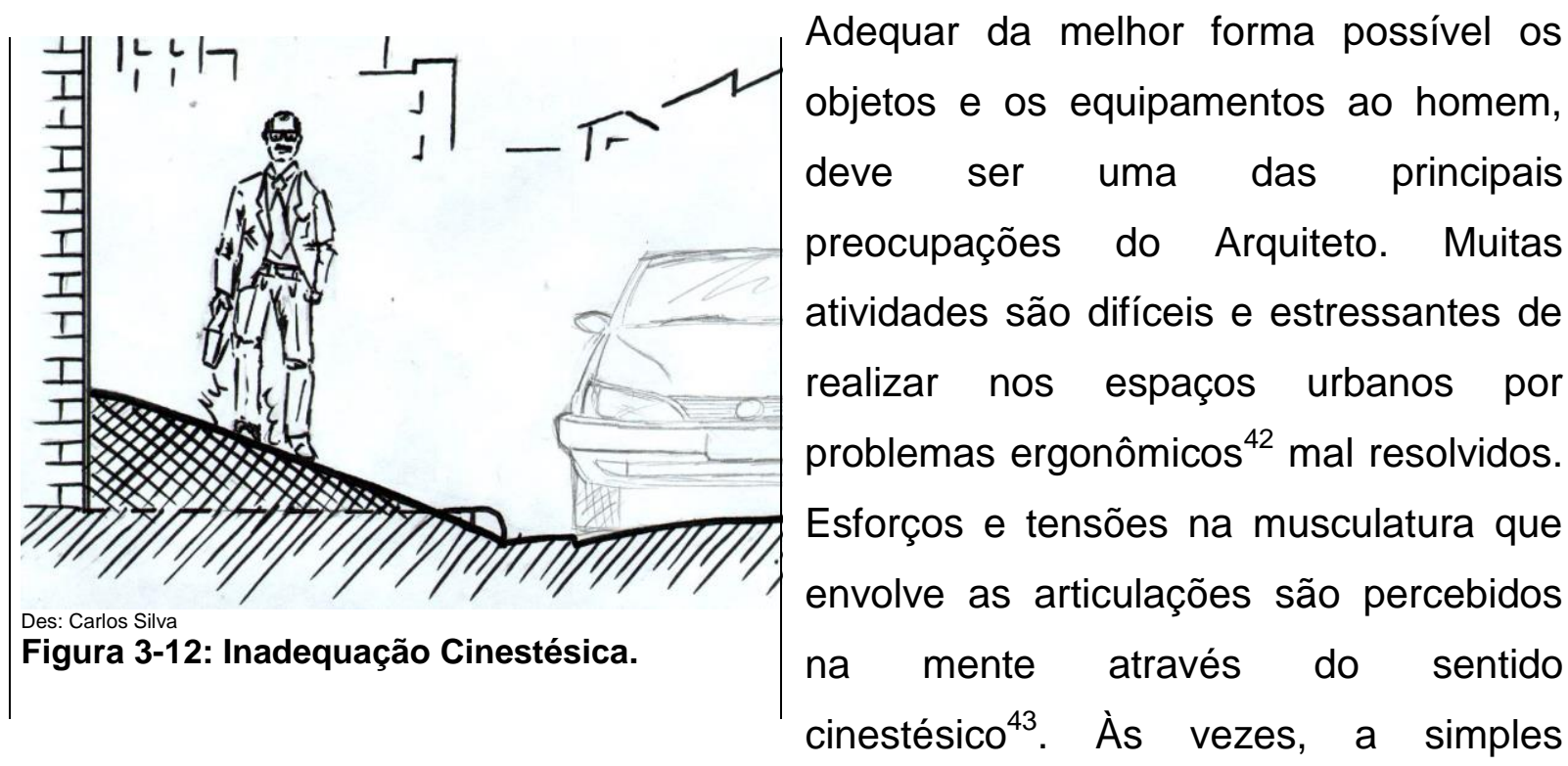

atividade de caminhar chega a ser impossível, em virtude de erros no traçado e dimensionamento dos caminhos ou por dificuldades interpostas por barreiras, desníveis e inadequações.

\subsubsection{Características de Higiene Ambiental (do Ar)}

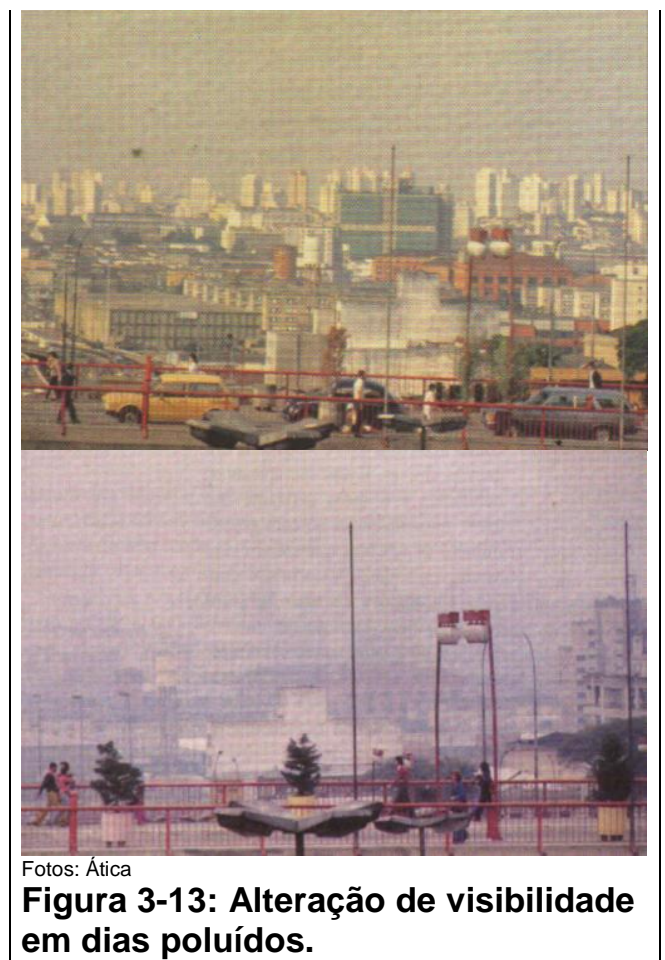

em dias poluídos.
Sendo a atmosfera o meio ambiente típico do ser humano, os estímulos em nossos sentidos, são produzidos por energias que se propagam no ar.

A higiene ambiental, enquanto meio ambiente, procura adequar os níveis das energias às quantidades necessárias para o correto funcionamento dos sentidos, porém, sem exceder níveis prejudiciais à saúde que causem desconforto ou que provoquem fadiga. Essas energias são: Luz, Ruído, Odor e Calor.

A atmosfera também é alimento, pois não podemos viver sem respirar. Nesse aspecto, a higiene ambiental trata da respirabilidade do ar examinando os níveis de poluição causados por:

\footnotetext{
${ }^{42}$ Ergonomia [De gr. erg(o) + nom(o) + ia.] Conjunto de estudos que visam à organização metódica do trabalho em função do fim proposto e das relações entre o homem e a máquina. Ciência da adaptação do trabalho ao homem, ciência que procura melhorar a atividade produtiva e o homem.

43 Cinestesia [De cin $(e)+$ estes(i) + ia.] Fisiologia: Sentido pelo qual se percebem os movimentos musculares, o peso e a posição dos membros.
} 
Gases e Material Particulado. A Companhia de Tecnologia de Saneamento Ambiental - CETESB de São Paulo, considera que "Poluente do Ar é qualquer substância presente no ar que pela sua concentração possa torná-lo impróprio, nocivo ou ofensivo à saúde, inconveniente ao bem estar público, danoso aos materiais, à fauna e à flora ou prejudicial à segurança, ao uso e gozo da propriedade e às atividades normais da comunidade." 44

\subsubsection{Iluminação}

Nos espaços abertos, os níveis de iluminância ${ }^{45}$ dependem da luz difusa do céu, da porção de céu visível e do grau de reflexão das superfícies. Os tipos de atividades desempenhadas condicionam as necessidades de iluminação.

\subsubsection{Ruídos}

Nas áreas urbanas predominam os ruídos gerados por veículos, tais como: automóveis, caminhões, ônibus, motocicletas, trens e aviões; pelos meios de produção como: indústrias em geral e equipamentos das atividades de construção civil; e os ruídos produzidos por estabelecimentos do setor terciário da economia, a exemplo de clubes, escolas, casas

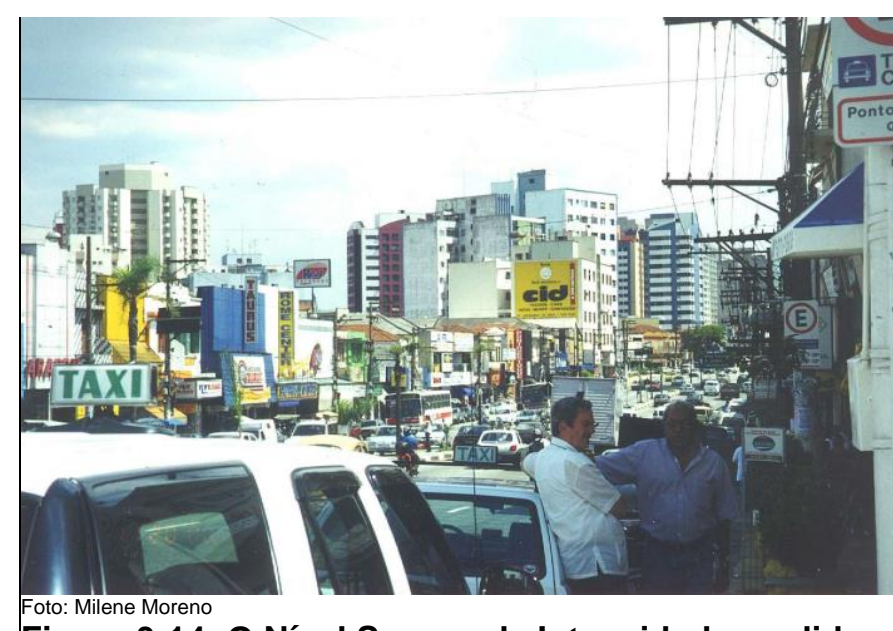

Figura 3-14: O Nível Sonoro de Intensidade medido no momento da foto foi $86 \mathrm{dBA}$. de diversão, bares e lanchonetes.

A caracterização de som depende da Intensidade (potência, em w/m² ou NSI em $\mathrm{dB}$ ); da Altura (grave, médio ou agudo; em c/s); e da Duração (tempo, em s). Segundo Conrado Silva DE MARCO ${ }^{46}$ os valores de alguns níveis sonoros de intensidade (NSI), expresso em decibels, são: 40dB dormitório; 50dB escritório movimentado; $60 \mathrm{~dB}$ conversa normal; $80 \mathrm{~dB}$ tráfego intenso; $100 \mathrm{~dB}$ indústria barulhenta; $120 \mathrm{~dB}$ avião a jato a curta distância. Os níveis sonoros de intensidade suportáveis, são definidos em função das atividades que serão realizadas. Conforme

\footnotetext{
44 CETESB, Qualidade do ar na região metropolitana de São Paulo e Cubatão, S. Paulo, Governo Estado de São Paulo, 1990. 45 [De iluminar + ância.] lluminamento; lluminação; Fluxo luminoso incidente por unidade de área de uma superfície iluminada.

${ }^{46}$ DE MARCO, Conrado Silva - Elementos de Acústica Arquitetônica, São Paulo, Editora Nobel, 1982. (p.13)
} 
a Portaria 92/80 de Ministério do Interior (citada no item 2.4.1) o máximo de dia é de $70 \mathrm{~dB}(\mathrm{~A})$ e o máximo à noite é de $60 \mathrm{~dB}(\mathrm{~A})$.

\subsubsection{Odores}

As urbes têm odores diferentes dos aromas que associamos ao meio natural. São os cheiros de fumaças e gases liberados por veículos, rios, córregos, lixo em decomposição, galerias de esgotos, fezes de animais, chaminés e materiais em combustão. Existem odores extremamente desagradáveis, até mesmo insuportáveis, porém, não há parâmetros de quantificação e nem aparelhos de medição que se apliquem a qualquer substância genericamente.

\subsubsection{Calor}

As cidades são aglomerações repletas de atividades e todas elas produzem e consomem formas de energia. Os vários tipos de energias sofrem transformações, de umas nas outras, porém, sempre em direção ao calor de baixa temperatura, que é a forma menos estruturada de energia, isto é, todo uso energético termina como calor no ambiente. Outro motivo pelo qual as cidades retêm mais calor que o entorno não urbanizado, são os tipos de materiais que as compõem, como: concreto, asfalto, metais, cimento amianto, etc. Materiais que têm menor inércia térmica, absorvem e perdem calor com maior rapidez. A tudo isso se acresce o fato de que nas grandes cidades, a fumaça e a fuligem escurecem as construções rapidamente e, como sabemos, as superfícies escuras absorvem mais energia que as mais claras, contribuindo assim para reter mais calor.

\subsubsection{Gases}

Tradicionalmente, as maiores fontes de poluição, nas grandes cidades brasileiras, têm sido as atividades industriais. Nas últimas décadas, com o aperfeiçoamento dos sistemas de produção, a descentralização das fábricas e a passagem das metrópoles de industriais para prestadoras de serviços, tem-se constatado a diminuição da poluição industrial e a principal fonte de poluentes passou a ser a crescente frota de veículos. Os gases poluentes mais freqüentes são: Monóxido de Carbono (CO), Dióxido de Enxofre $\left(\mathrm{SO}_{2}\right)$, Dióxido de Nitrogênio $\left(\mathrm{NO}_{2}\right)$ e Oxidante Fotoquímico - Ozônio $\left(\mathrm{O}_{3}\right)$.

\subsubsection{Material Particulado}

A produção de resíduos e poeiras, associada a deficiências na varrição, precariedade da limpeza urbana e a movimentação dos veículos, tem mantido altos 
os índices de poluição por partículas em nossas cidades. Consideram-se, para efeito

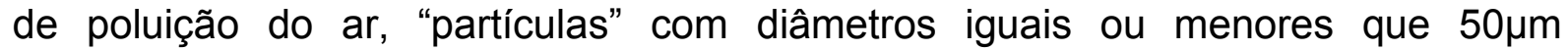
(cinqüenta micrômetros), adotando-se a expressão "partículas inaláveis" ou

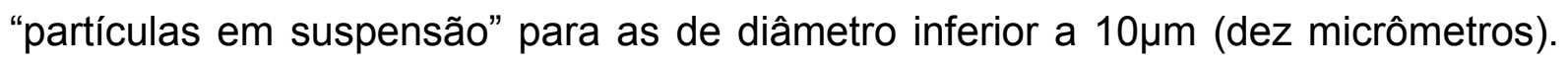
Esse material, por ter velocidade de sedimentação muito baixa, tende a permanecer em suspensão por horas e até dias, reduzindo a visibilidade ${ }^{47}$. Além disso, são prejudiciais à saúde por penetrarem profundamente no sistema respiratório.

\subsubsection{Lixo e Sujeira}

A produção de resíduos sólidos domésticos e comerciais, nas grandes cidades, é proporcional ao padrão de consumo de sua população. Geralmente excede $1 \mathrm{~kg} / \mathrm{hab} / \mathrm{dia}$, chegando a mais de $2 \mathrm{~kg} / \mathrm{hab} / \mathrm{dia}$ nas cidades norteamericanas. Em termos ambientais, o problema é o gerenciamento desse lixo,

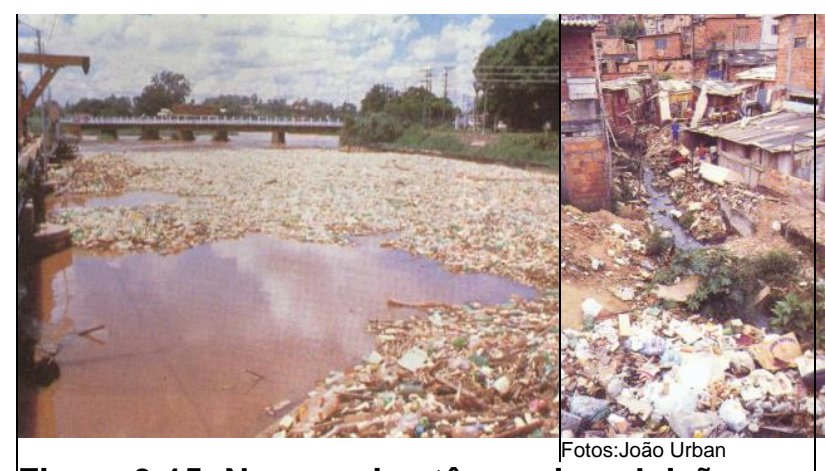

Figura 3-15: Nossos rios têm mais poluição por lixo do que por esgotos.

tanto por parte da população como de seus representantes. O padrão de limpeza urbana reflete o nível cultural-educacional da população. Ocorre que a natureza, de alguma forma, mais cedo ou mais tarde, sempre acaba fechando os ciclos, restabelecendo um novo equilíbrio, porém, em outras bases com outras relações, nem sempre favoráveis para os seres humanos. O exemplo mais flagrante é que o lixo urbano que dificulta a vazão dos córregos e rios, causa as inundações e acaba voltando, invadindo as moradias, trazido pelas enchentes.

\subsubsection{Características Climáticas}

A expressão Clima deriva da palavra grega "klíma", cujo significado é inclinação, propensão, disposição, tendência, pendor. O Clima, de um lugar, é a tendência média de comportamento do conjunto das condições meteorológicas da atmosfera ao longo dos anos. As principais variáveis climáticas são: insolação, ventos, umidades e temperaturas ${ }^{48}$.

\footnotetext{
47 As partículas inaláveis recebem o nome de fumaça ou fuligem quando têm grau de opacidade suficiente para dificultar a visibilidade.

${ }^{48}$ Mais informações sobre as relações dos Climas com a Arquitetura e o Urbanismo: OLGYAY, Victor - Design with climate Princeton, Princeton University Press, 1963; FORSDYKE, A. G. - Previsão do Tempo e Clima, São Paulo, Melhoramentos-
} 


\subsubsection{Insolação}

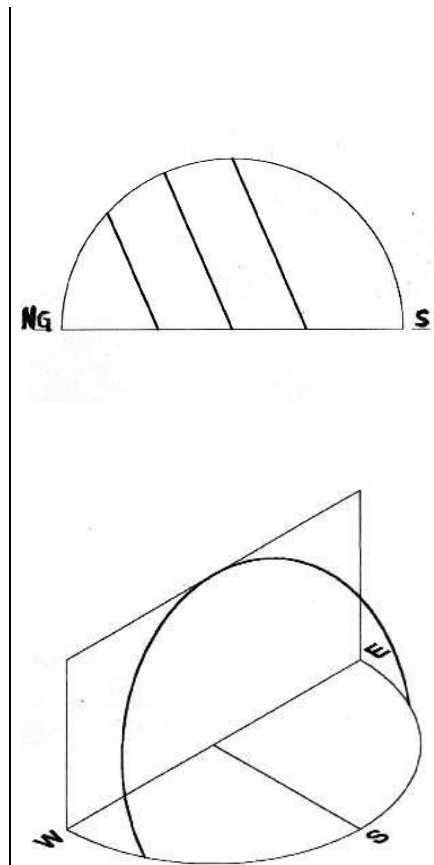

Face Sul recebe Sol o Verão todo.
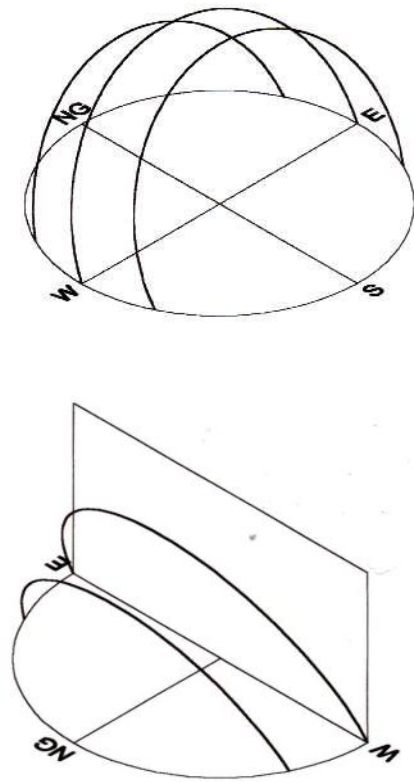

Face Norte recebe Sol no Inverno e Equinócios.

Figura 3-16: Trajetórias do Sol no Trópico de Capricórnio, Hemisfério Sul.

Do ponto de vista ecológico, a radiação solar é o único componente do ecossistema que vem de fora da Terra. Em termos climáticos, ocorre algo parecido; é a energia solar que impele todas as outras variáveis. A insolação é tão importante que uma adequada orientação na implantação de um projeto arquitetônico ou urbanístico resolve mais da metade dos problemas de conforto térmico.

A incidência da insolação altera a sensação térmica. Se o ar está a uma dada temperatura, quanto maior a intensidade da radiação, maior será a sensação de aquecimento percebida.

No aspecto urbano, considerando-se o Hemisfério Sul, deve-se propiciar insolação, qualquer que seja o clima, na face Norte, porque recebe boa insolação no inverno e nos equinócios ${ }^{49}$. Também se deve favorecer a face Leste por receber Sol, somente de manhã, o ano todo.

A insolação na face Oeste deve ser evitada nos climas quentes por fornecer calor à tarde, justamente no período mais quente do dia; convém privilegiar a face Oeste em climas frios.

No Hemisfério Sul, ao contrário do que muitos profissionais pensam, a face Sul deve ser evitada em qualquer clima, pois é inadequada no verão por receber muito Sol quando faz mais calor; e também é desfavorável no inverno por não receber insolação quando faz mais frio.

Edusp, 1975; RAMÓN, Fernando - Ropa, Sudor y Arquitecturas, Madrid, H.Blume Ediciones, 1980; RIVERO, Roberto Arquitetura e Clima, acondicionamento térmico natural, Porto Alegre, Sagra - Luzzatto, 1985; ROMERO, Marta A. Bustos Princípios Bioclimáticos para o Desenho Urbano, São Paulo, Projeto Editores, 1988.

${ }^{49}$ Equinócios [Do latim aequinoctiu.] Ponto da órbita da Terra em que se registra uma igual duração do dia e da noite, o que sucede nos dias 21 de março e 23 de setembro, no hemisfério sul, respectivamente, equinócio de outono e equinócio de primavera. 


\subsubsection{Ventos}

Nos climas quentes, onde as temperaturas do ar excedem a do corpo humano, as trocas térmicas por convecção $0^{50}$ devem ser evitadas, porque o calor flui para a

pessoa, aumentando a temperatura de seu corpo. Nos climas frios também se deve impedir a convecção para que a pessoa não perca ainda mais calor.

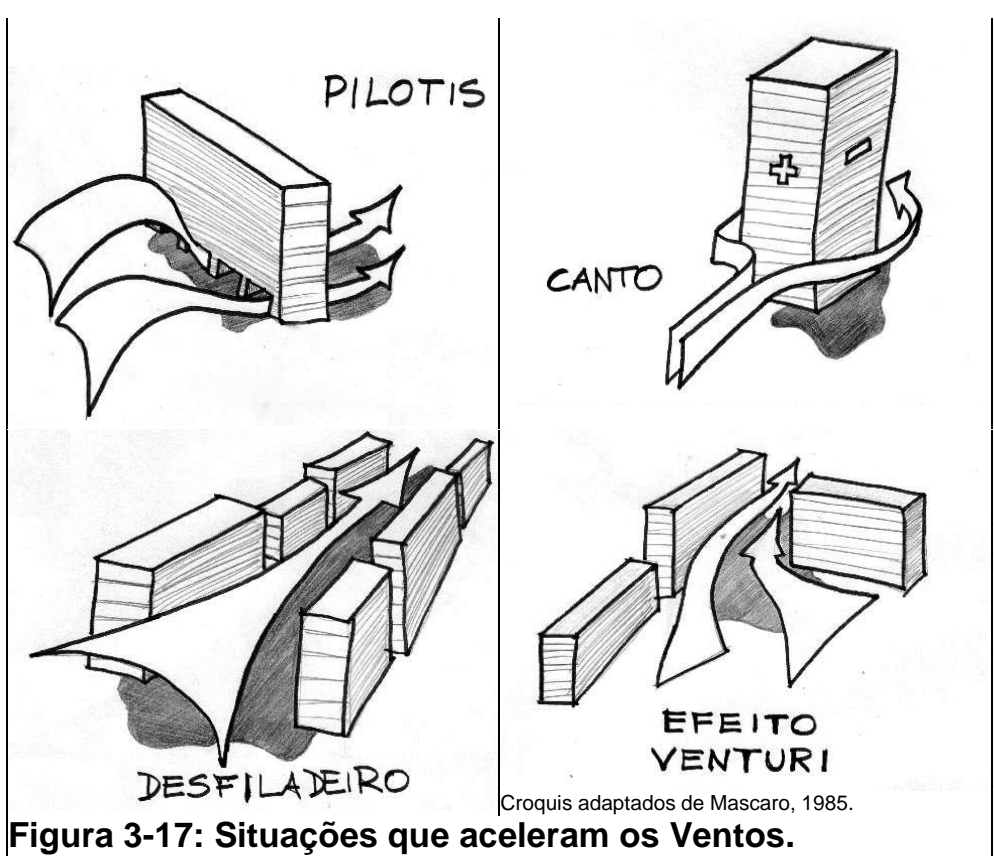

Nos outros climas, principalmente nos quentes e úmidos, onde as perdas térmicas por evaporação são impedidas pelo ar saturado de vapor, a ventilação assume papel fundamental retirando calor por convecção. Sempre que o ar não exceda a temperatura do corpo, a ventilação causa a sensação de esfriamento.

Nas cidades, a textura do conjunto das edificações tende a refrear a velocidade do ar; por outro lado, determinadas volumetrias ou disposições aceleram os ventos, como é o caso do "efeito canto" nas arestas das construções em geral, do "efeito desfiladeiro" em ruas ladeadas por edificações altas, ou do "efeito pilotis" que acelera o ar sob os edifícios. A disposição dos volumes pode causar redemoinhos de poeira, folhas e poluentes em geral, concentrando e agravando a qualidade ambiental.

\subsubsection{Umidade}

O ar seco é bom isolante térmico, já o ar úmido é bom condutor, por isso nos climas úmidos, tanto quentes como frios, as trocas de calor se acentuam, reforçando as sensações térmicas tanto de calor como de frio. Controlar a umidade do ar, na escala urbana, é difícil; o que se pode fazer para aumentar a umidade é utilizar lagos, espelhos d'água, fontes ou cascatas e, para reduzir a umidade somente aumentando a ventilação.

\footnotetext{
50 Convecção: transferência de calor pela movimentação de um fluido, neste caso o fluido é o ar (vento).
} 
Outro aspecto da umidade a ser considerado, é o regime de precipitações. Consideram-se desérticas, as regiões com precipitações abaixo de $250 \mathrm{~mm} / \mathrm{ano}$ e chuvosas as que tenham acima de $1000 \mathrm{~mm} / \mathrm{ano}$.

De maneira geral, as grandes áreas urbanas por impermeabilizarem extensas áreas, pela canalização de galerias, córregos e rios que reduzem as superfícies de água, tendem a ter climas cada vez mais secos.

\subsubsection{Temperaturas}

O regime de variações térmicas é o principal indicador climático. As variações sazonais ilustram o comportamento térmico das estações do ano; por exemplo, os climas úmidos apresentam pequenas

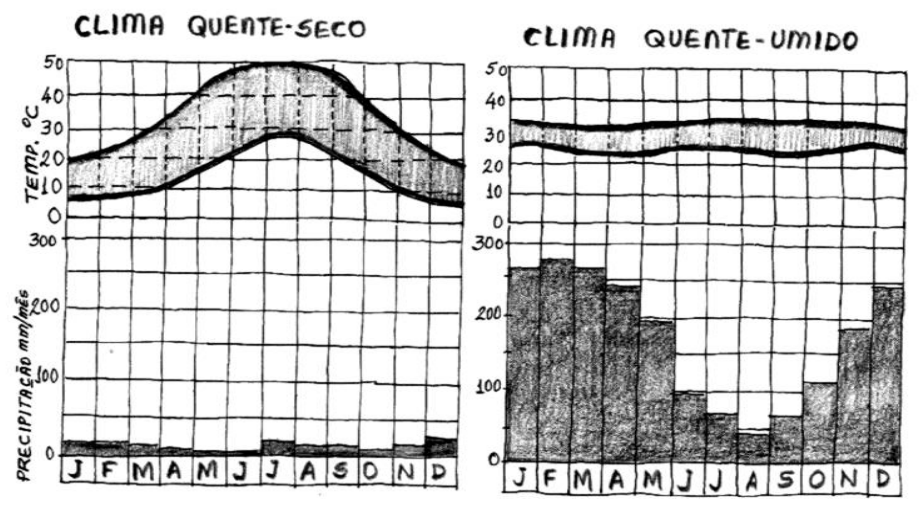
oscilações de temperaturas anuais, porque o vapor d'água Figura 3-18: Gráficos de Temperaturas e Precipitações nos Climas: Quente - Seco e Quente - Úmido.

na atmosfera funciona como amortecedor térmico dificultando a liberação de energia para o espaço. Nos climas secos, as variações são muito mais amplas, com verões muito quentes e invernos frios; isso ocorre porque a inexistência de umidade facilita as trocas térmicas por irradiação para fora da atmosfera.

De maneira semelhante, as variações térmicas ao longo das horas do dia indicam, para os climas úmidos, que de dia e à noite as temperaturas são as mesmas, enquanto nos climas secos, de dia as temperaturas são altas e à noite costumam ser mais baixas.

As grandes cidades, por serem grandes geradoras de calor e pelas características dos materiais que a constituem, têm maior propensão para reter calor durante o dia, produzindo ilhas de calor; e por terem esfriamento rápido, ao anoitecer ocasionam inversões térmicas noturnas. 


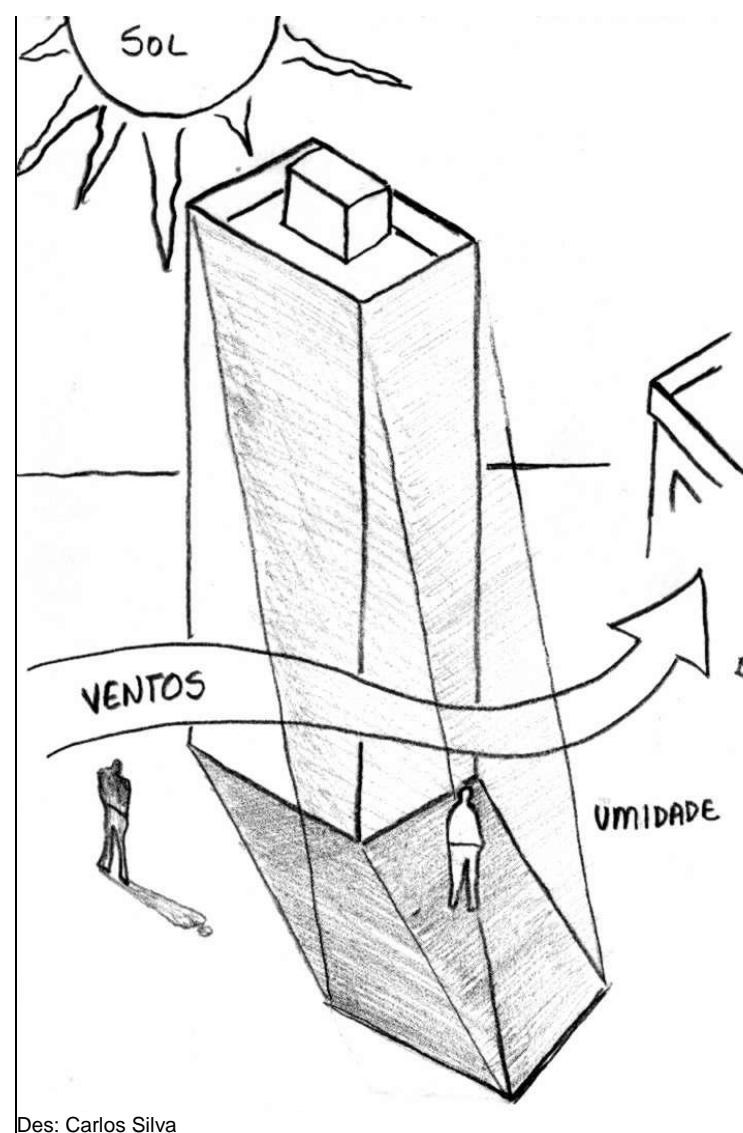

Figura 3-19: Clima Local.

\subsubsection{Microclima Local}

As alterações locais de insolação, ventos, umidade e temperaturas, em meio ao tecido urbano, propiciam situações climáticas específicas. As áreas sob as sombras dos edifícios e as áreas onde os ventos se aceleram, passam sensações térmicas mais baixas, mais frias, do que nas áreas sem essas ocorrências. O aumento da umidade do ar facilita as trocas térmicas, já que o ar úmido é bom condutor de calor, e isso tende a acentuar as sensações tanto de frio como de calor; aliás, o clima quente saturado de umidade causa a sensação de mormaço, que é extremamente desconfortável, porque o corpo se esforça para liberar suor, mas não obtém perda térmica porque como o ar está pleno de umidade, o suor não consegue passar para vapor e retirar calor do corpo. Não sendo possível perder calor por evaporação, a melhor opção passa a ser a convecção, estimulando a ventilação.

\subsection{Caracterização Ambiental da Cidade de São Paulo}

A Caracterização Ambiental Paulistana descreve a morfologia natural do sítio em que está implantada a cidade de São Paulo, analisa a morfologia urbana e como elas interagem com os aspectos da Higiene Ambiental e do Clima.

\subsubsection{Morfologia Natural de São Paulo}

\subsubsection{Localização e Continentalidade}

As coordenadas geográficas do Marco Zero da Cidade de São Paulo, que fica na Praça da Sé, são: latitude $23^{\circ} 32^{\prime} \mathrm{S}$, longitude $46^{\circ} 37^{\prime} \mathrm{W}$ e altitude de $750 \mathrm{~m}$. Essa latitude é praticamente a do Trópico de Capricórnio (23⒉ $27^{\prime}$ Sul) que passa na região 
norte da cidade, sobre a Serra da Cantareira e, conseqüentemente, agrega algumas particularidades como: a radiação solar ficar perpendicular (Sol a pino) sobre São Paulo no solstício ${ }^{51}$ de verão, que ocorre anualmente na passagem meridiana do dia 22 ou 23 de dezembro, ou os ventos predominantes serem os Alísios que sopram da direção Sudeste.

A região metropolitana de São Paulo está relativamente próxima do oceano Atlântico, o que faz com que durante a maior parte do ano, entre setembro e abril, os ventos que a percorrem estejam carregados de umidade marinha.

\subsubsection{Relevo e Bacias}

A cidade de São Paulo está em um sítio de relevo bastante acidentado, que é descrito como uma bacia sedimentar de planalto. A bacia do Planalto Paulistano

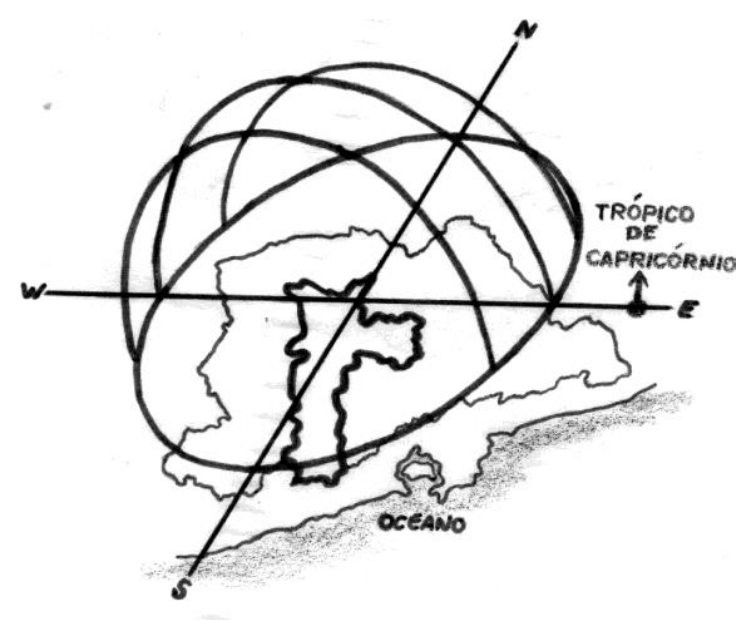

Des: Carlos Silva

Figura 3-20: Trópico de Capricórnio em São Paulo. não se localiza no topo do relevo, mas na encosta Sudeste, entre as cotas 720m (no Cebolão) e 820m (na Av. Paulista), portanto, muito abaixo dos $1050 \mathrm{~m}$ que é a cota média da Serra da Cantareira ou dos $1133 \mathrm{~m}$ do seu ponto mais alto que é o Pico do Jaraguá, isso faz com que receba os ventos úmidos do oceano. Na realidade, se a cidade de São Paulo estivesse além do topo da Serra da Cantareira, na direção Noroeste, teríamos a face seca do efeito orográfico $^{52} \mathrm{com}$ um clima menos úmido, menos influenciado pelos ventos do oceano. A serra forma um obstáculo natural que retém as frentes frias lentas, acentuando as inversões térmicas e, assim, dificultando

a dispersão de poluentes.

\footnotetext{
51 Solstício [Do lat. solstitiu.] Instante em que o Sol está em sua maior declinação boreal ou austral e, a partir da qual, deixa de afastar-se do Equador. [Os solstícios situam-se, respectivamente, nos dias 22 ou 23 de junho para a maior declinação boreal, e nos dias 22 ou 23 de dezembro para a maior declinação austral do Sol. No hemisfério sul, a primeira data se denomina solstício de inverno e a segunda, solstício de verão; e, como as estações são opostas nos dois hemisférios, essas denominações invertem-se no hemisfério norte.]

52 Efeito Orográfico: [De or(o)] Relativo as montanhas; Quando os ventos incidem em uma elevação são forçados a subir para camadas mais frias causando a condensação de vapor e precipitações, é a face úmida; ao passar a elevação tende a descer para camadas mais quentes da atmosfera, esse aquecimento faz com que a umidade se mantenha no estado de vapor, é a face seca.
} 


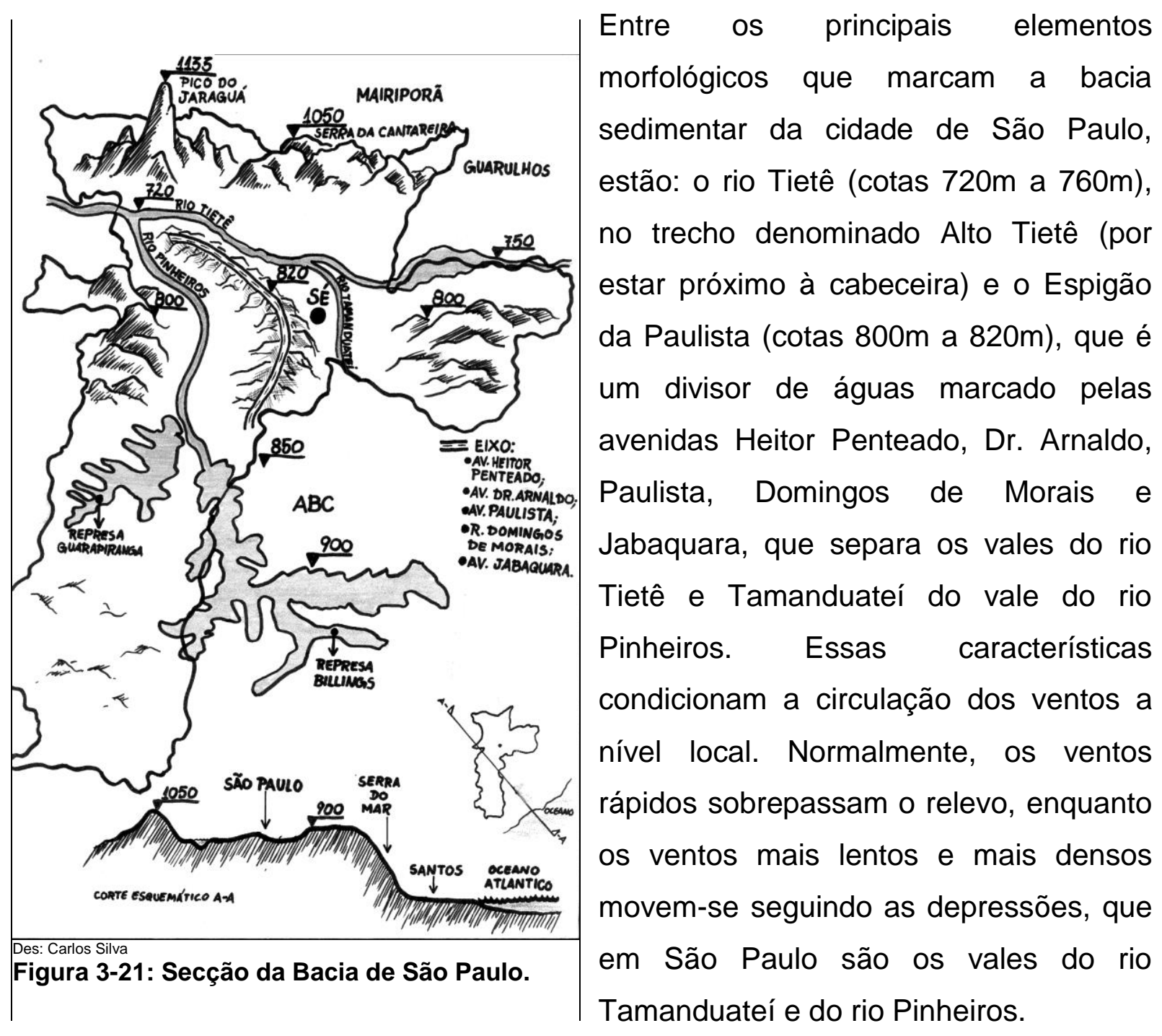

\subsubsection{Morfologia Urbana de São Paulo}

Imerso no ambiente natural está o ambiente urbano, formado por estruturas construídas pela sociedade. A intensidade e abrangência do impacto na natureza têm aumentado e uma parcela significativa dessas transformações tem contado com a participação dos profissionais da arquitetura e do urbanismo.

Muitas vezes, os profissionais realizam empreendimentos e não visualizam as transformações ambientais que suas obras estão deflagrando. Abordar os aspectos da qualidade ambiental urbana em que a atuação do Arquiteto e Urbanista interfere, é o primeiro passo para que os profissionais do projeto possam contribuir para melhorar a qualidade ambiental urbana. 


\subsubsection{Urbanização}

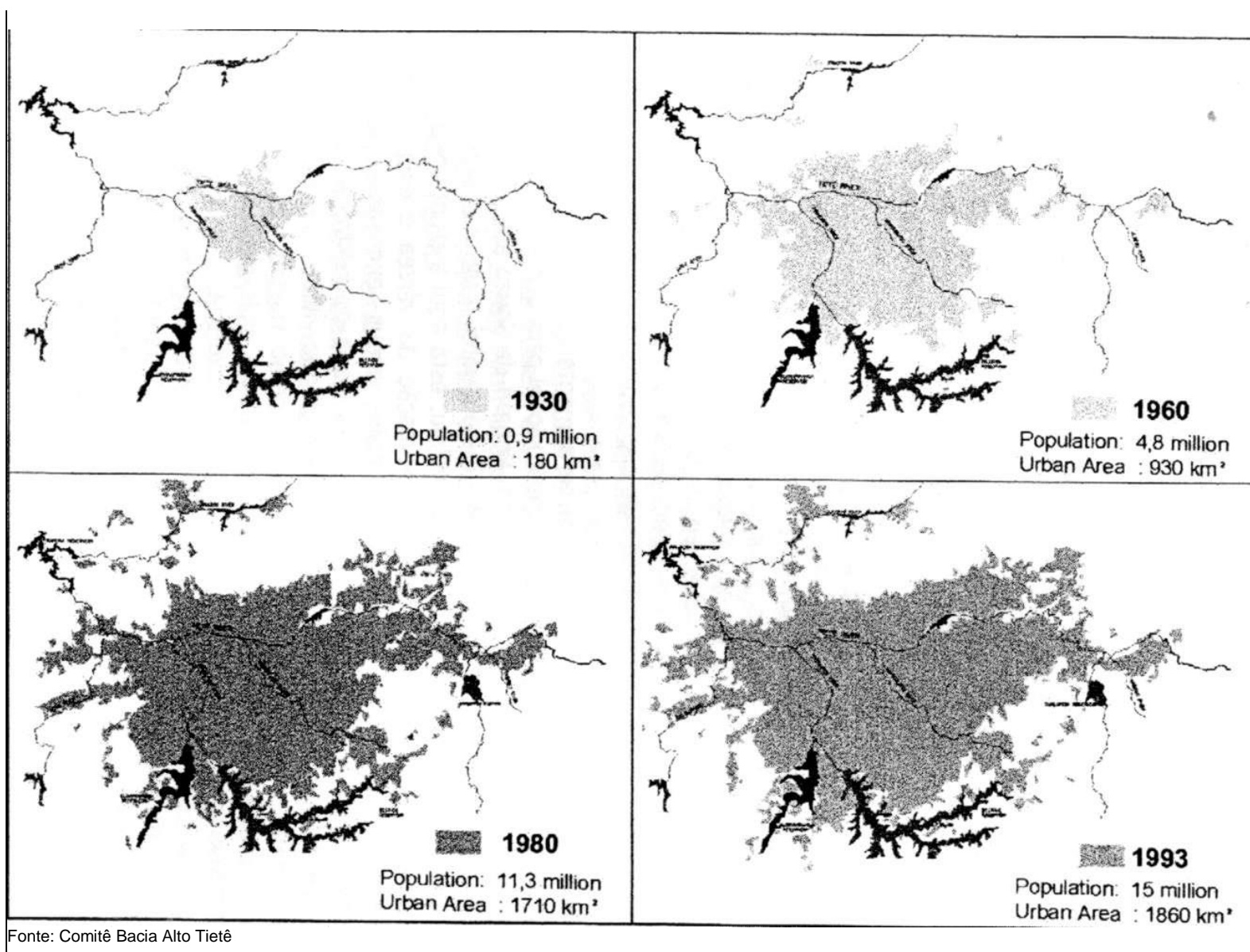

Figura 3-22: Expansão da mancha urbana na Região Metropolitana de São Paulo.

A superfície urbanizada recobre praticamente toda a área metropolitana. $\mathrm{Na}$ cidade de São Paulo, apenas no extremo Sul, onde fica a APA ${ }^{53}$ Municipal Capivari Monos, ainda se observam alguns trechos não urbanizados, mas por pouco tempo, porque apesar da legislação, continuam os loteamentos clandestinos e as invasões, comprometendo toda a área de preservação dos mananciais.

$\mathrm{Na}$ macro-escala, as principais transformações causadas pela urbanização paulistana, ocorrem nas alterações dos ciclos biogeoquímicos.

\subsubsection{Ciclo de Energia}

As sociedades urbanas gastam e desperdiçam muita energia. Dependendo do uso, fazemos várias transformações de tipos de energia e cada transformação implica em perdas, liberadas para o ambiente na forma de calor. Isso pode ser evitado usandose a fonte energética correta, que forneça a energia efetivamente necessária ao

${ }^{53}$ APA: Área de Preservação Ambiental. 
equipamento, sem transformações. Por exemplo: os materiais urbanos absorvem energia, as construções também; gasta-se muita energia para jogar no meio ambiente a energia que não deveria ter sido assimilada; as caixas de vidro, com gigantescas centrais de ar condicionado, ilustram bem esse problema.

Outro exemplo, tradicionalmente usa-se energia elétrica para aquecer a água do chuveiro ou da ducha; ocorre que a energia necessária, em tal processo, é a térmica e não a elétrica, isso implica em transformações que podem ser evitadas; a energia solar e o gás natural são fontes que produzem energia térmica diretamente, sem transformações, são fontes mais adequadas para aquecer água do que as fontes hidroelétricas ou termoelétricas, que passam por diversas transformações antes de se transformar em calor.

O arquiteto e urbanista pode contribuir gerenciando melhor o uso da energia ou até eliminando consumos desnecessários. Toda energia produzida acaba sendo liberada como calor. Junte-se a isto, as propriedades dos materiais urbanos que

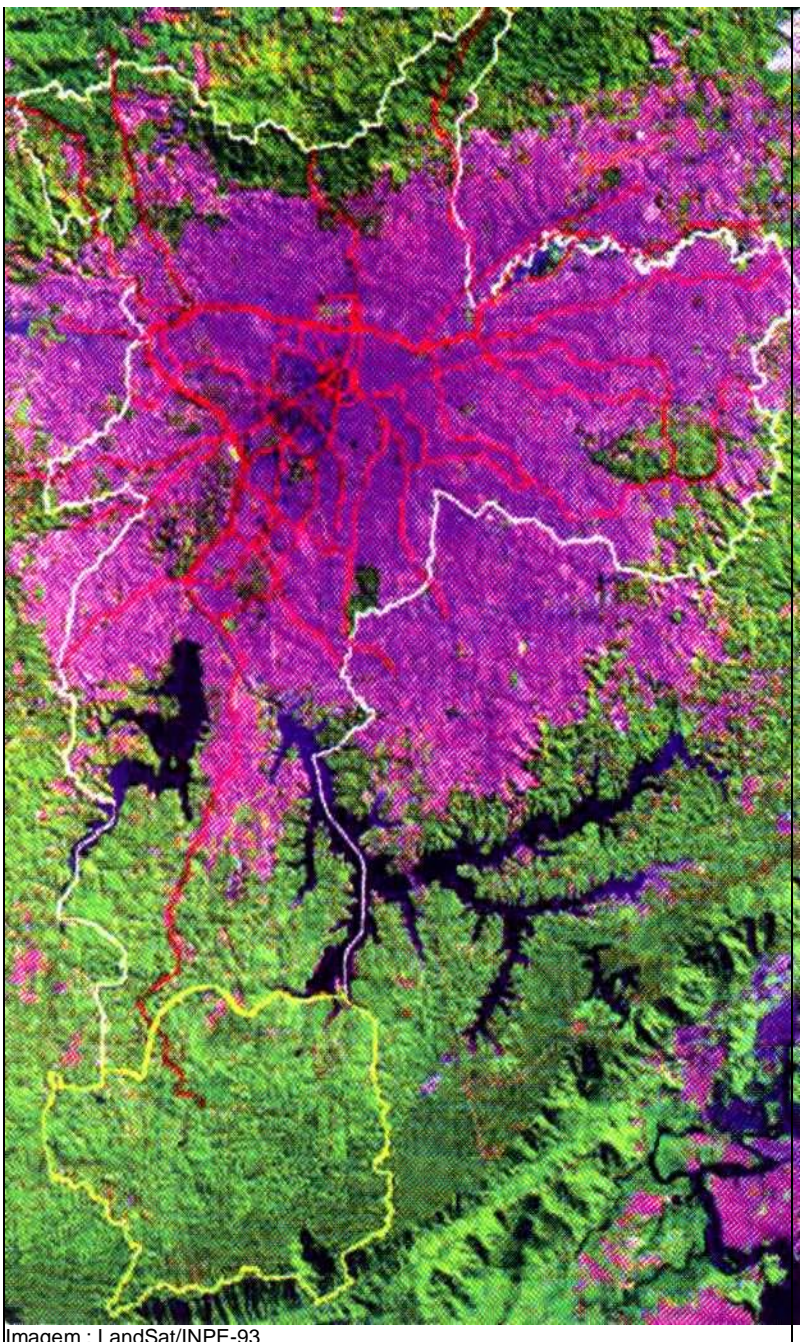

Figura 3-23: Represas ao Sul da área urbanizada. absorvem energia e também liberam calor, mais os poluentes que produzem o efeito estufa e retém o infravermelho e teremos freqüentes aquecimentos diurnos conhecidos como ilhas de calor, e ao anoitecer, o rápido esfriamento das camadas de ar junto ao solo causando inversões térmicas.

\subsubsection{Corpos D’Água e Represas}

$\mathrm{Na}$ Grande São Paulo, outras intervenções humanas que impactam o meio natural são as superfícies de água formadas pelas represas Billings e Guarapiranga, que alagam grandes áreas, funcionam como bolsões de ar frio e alteram a umidade do ar. Os rios Tietê, Pinheiros e Tamanduateí; completam os cinco principais corpos d'água metropolitanos. Todos eles estão muito 
modificados, pois até os rios foram refeitos, através de retificações, canalizações, comportas e estações elevatórias. O rio Pinheiros teve seu curso revertido, sendo suas águas bombeadas para a Billings no alto da Serra do Mar.

\subsubsection{Permeabilidade e Drenagem}

A capacidade drenante do solo vai diminuindo à medida que a expansão urbana impermeabiliza 0 solo. Por exemplo, em áreas verticalizadas, a superfície impermeável em geral excede $90 \%$ da área total. Isso ocorre porque um ou mais subsolos são destinados a garagens e ocupam praticamente toda a área do terreno, pois a legislação permite, que os subsolos para garagens, cheguem até as divisas $^{54}$.

Conseqüentemente, é comum que a vegetação e os jardins estejam sobre as lajes impermeabilizadas, dos estacionamentos.

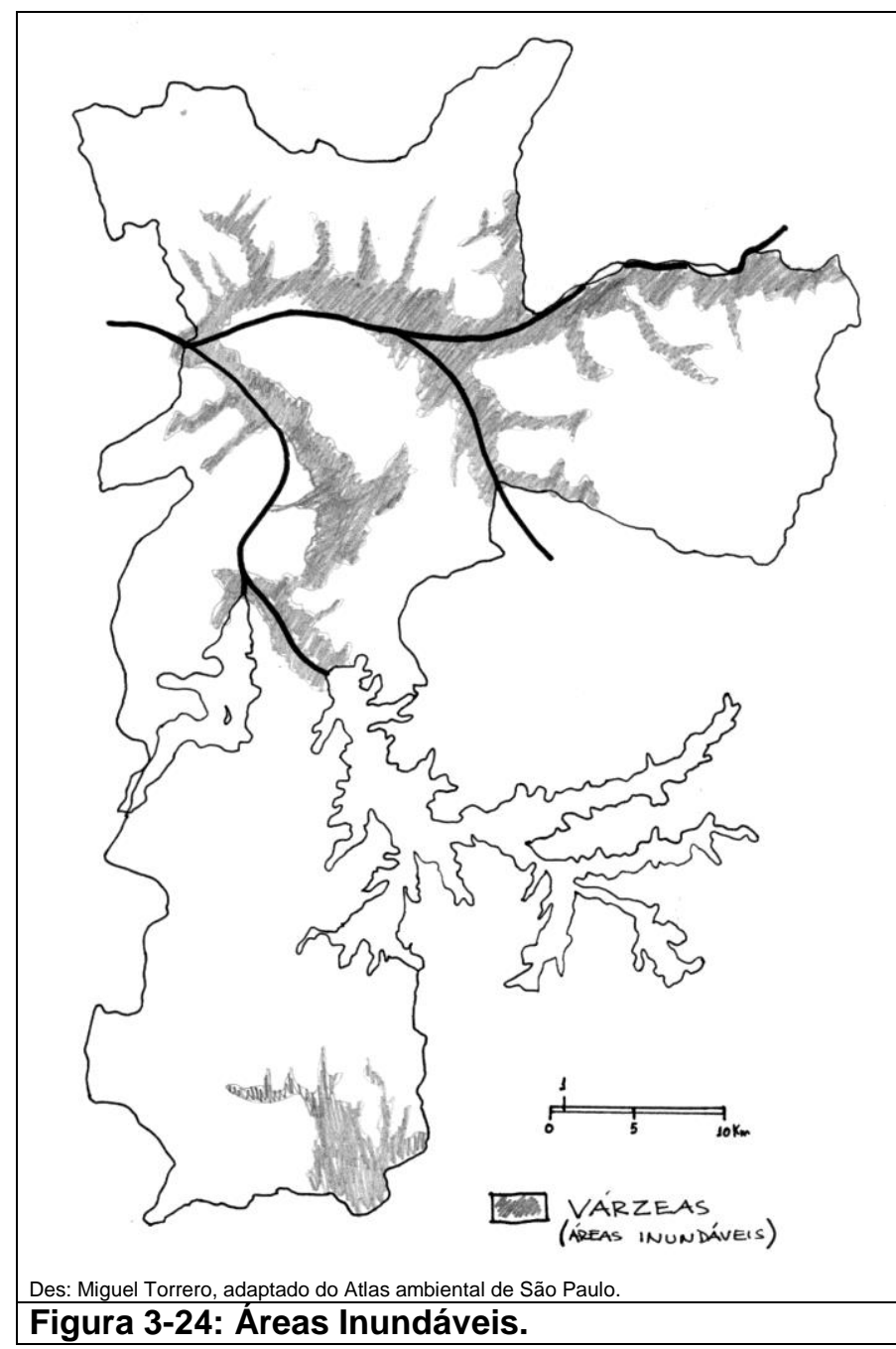

\footnotetext{
54 Art.34 da Lei 8328/75; com nova redação no Art.15 da Lei 10.334/87; resolução COGEP/CZ 34/76: Autoriza a ocupação dos recuos laterais e de fundo, por subsolos, desde que usados para estacionamentos. Essas áreas não são computadas no coeficiente de aproveitamento.
} 


\subsubsection{Ciclo Hidrológico}

As inundações ${ }^{55}$ são conseqüências que se repetem anualmente no período das chuvas de verão. A área impermeabilizada é tão grande que não há galerias de águas pluviais que consigam drenar o volume de água. A tendência é a situação piorar porque o clima urbano produz variações térmicas acentuadas e rápidas, com maiores aquecimentos durante o dia e bruscos esfriamentos ao anoitecer. As temperaturas mais altas das áreas urbanas significam maior capacidade de manter vapor d'água no ar, que os esfriamentos ao anoitecer se encarregam de precipitar. Em outras palavras, quanto maior e mais rápida for a amplitude de variação térmica, maiores serão as precipitações.

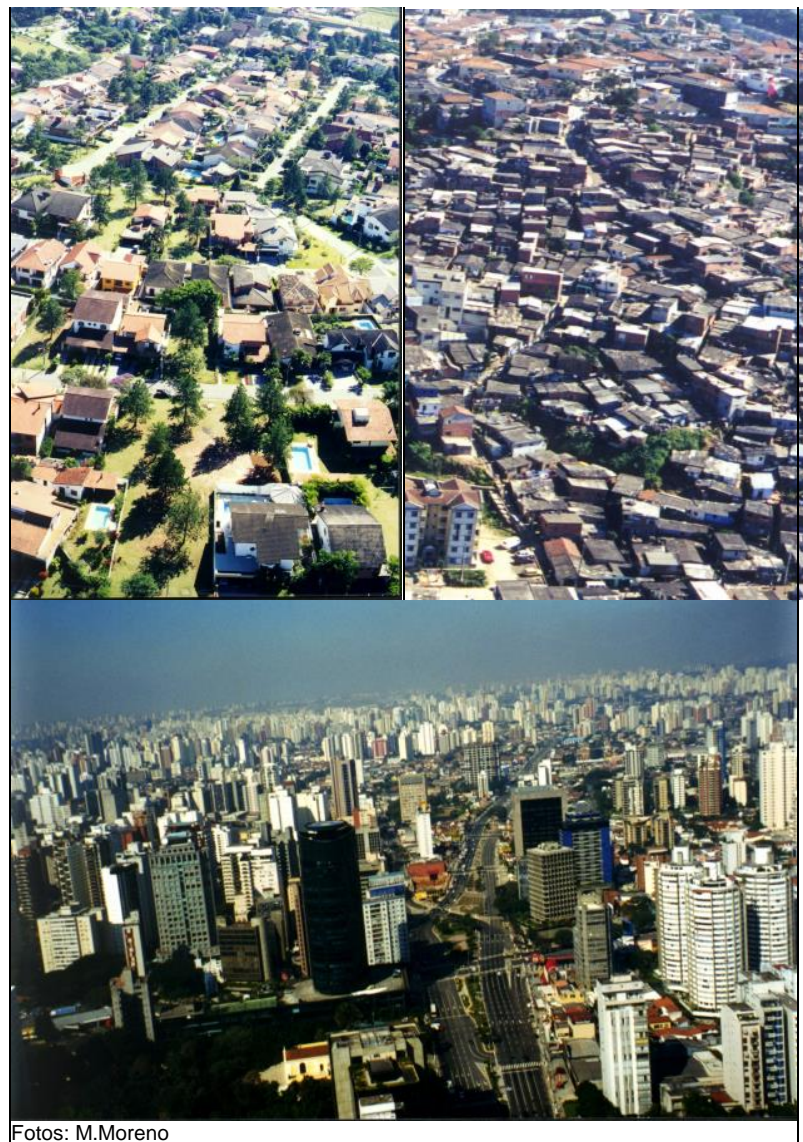

Figura 3-25: Impermeabilização quase total, nas áreas verticalizadas e nas favelas.

Uma sugestão para minorar o problema é que cada lote retenha a água da chuva e a libere lentamente, eliminando assim a onda de cheia ${ }^{56}$. Seria uma forma de restabelecer a dinâmica original, o ritmo que o ciclo hidrológico tinha antes da impermeabilização urbana. Sendo que, parte dessa água poderia ser usada para regar os jardins, lavar os pátios e até como reserva de incêndio.

\subsubsection{Vegetação}

Em São Paulo assim como em outras cidades a vegetação é vista como adversária dos empreendimentos e acaba perdendo lugar para as construções. É curioso que até loteamentos do tipo cidade-jardim, em sua implantação, façam uma total desvegetação da área para depois refazer o plantio das árvores. Foi assim com os

\footnotetext{
55 Inundação [Do latim inundatione.] Ato ou efeito de inundar (-se). Alagamento, enchente, cheia. Enchente: [De encher + nte.] Grande quantidade de água que se acumulou em rio, lago, etc., em decorrência de chuva forte, e gue, ao transbordar, provoca inundação de terras adjacentes; cheia das várzeas; alagamento.

${ }^{56}$ É o princípio dos piscinões, consiste em construir uma cisterna com saídas dimensionadas para um fluxo lento da água.
} 
empreendimentos da Cia. City, nos bairros jardins de São Paulo e também com os residenciais de Alphaville e Tamboré.

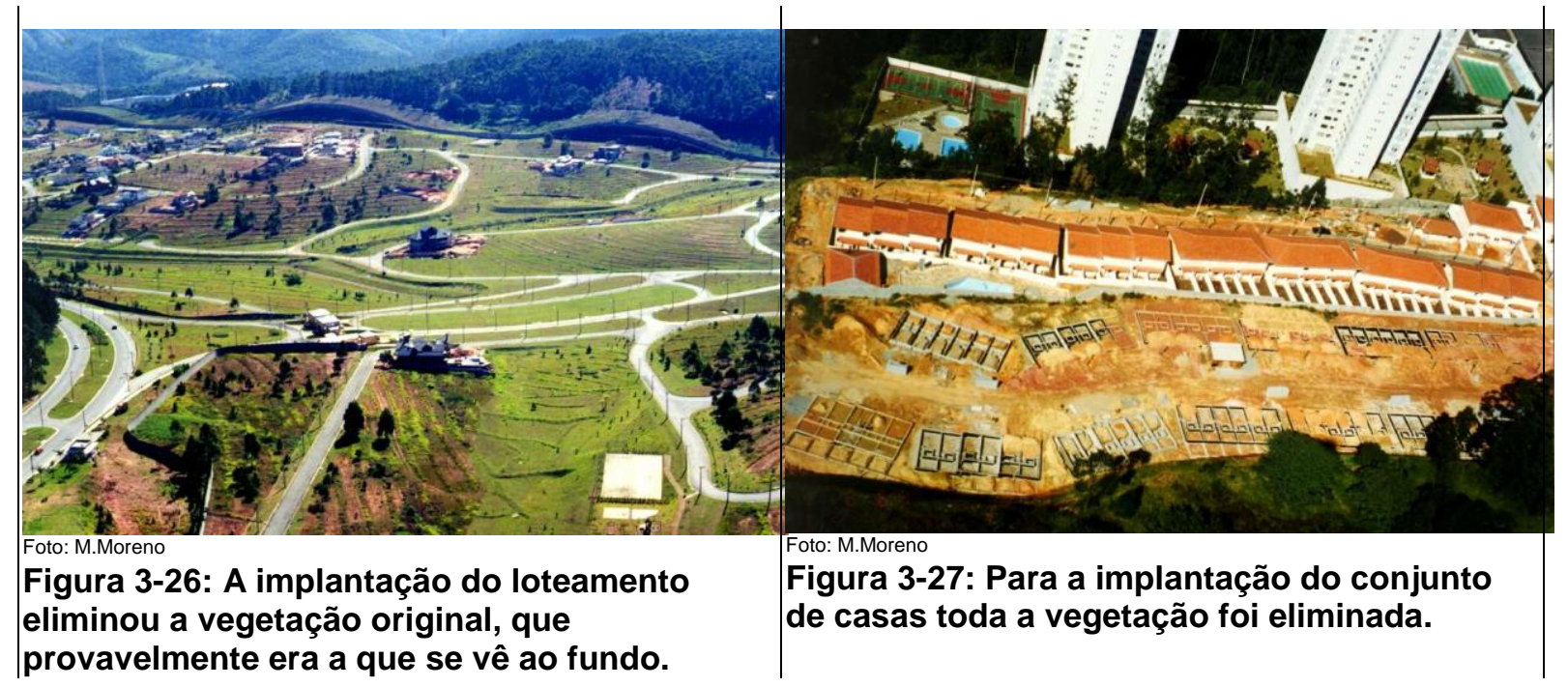

Mesmo que tenhamos em segundo plano a função ecológica da vegetação como produtora de oxigênio e nutrientes, em termos ambientais o efeito das massas arbóreas como atenuador térmico, filtro da radiação solar, amenizador dos ventos e redutor mecânico de poeiras e fuligens, deve ser considerado.

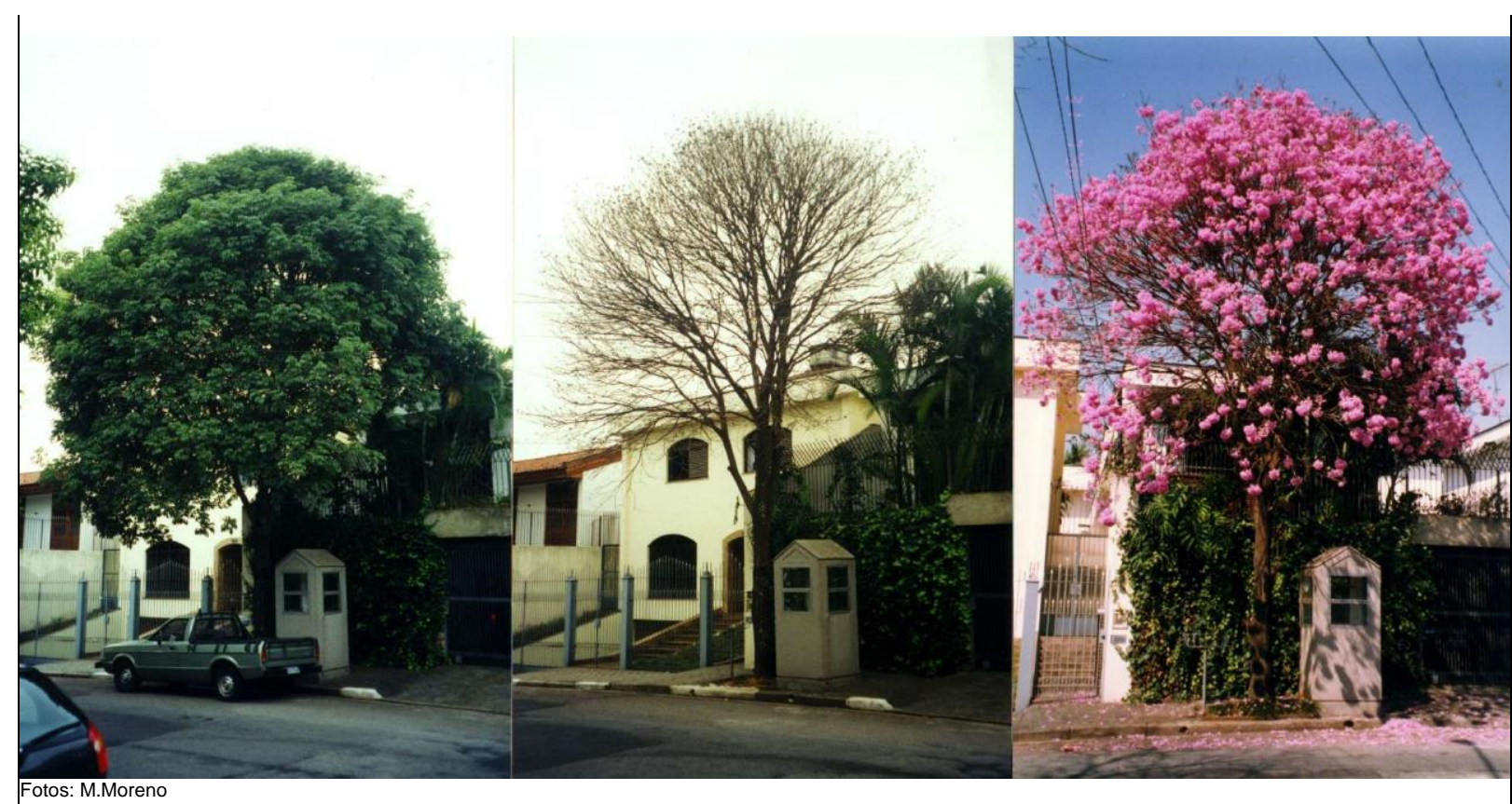

Figura 3-28: Ipê Roxo com a copa verde em janeiro; desfolhado no inverno no início de julho de 1998; e florida em 31 de julho de 1998.

O que caracteriza a vegetação paulistana são os contrastes, temos grandes áreas completamente desprovidas de qualquer tipo de vegetal, muito menos de árvores. Em outras partes da cidade, temos verdadeiras florestas urbanas, como é o caso dos bairros jardins, que após meio século, têm uma massa arbórea consolidada. 


\subsubsection{7 Áreas de Risco}

Sendo 0 relevo paulistano bastante movimentado, com muitas áreas de grande declividade, à medida que aumentam os índices pluviométricos, maiores são as probabilidades de deslizamentos de encostas. Ricardo Brandão FIGUEIREDO ${ }^{57}$ define áreas de risco como "...locais sujeitos à ocorrência de fenômenos de natureza geológicogeotécnica e hidráulica que impliquem a possibilidade de perda de vidas e/ou danos materiais. Esses locais são, predominantemente, ocupações de fundo de vales sujeitos a inundações e solapamentos, ou encostas de altas declividades passíveis de escorregamentos e desmoronamentos.", ressaltando dados da PMSP. "Em 1973, havia 542 favelas na cidade, passando

Figura 3-29: Areas de Risco com grande

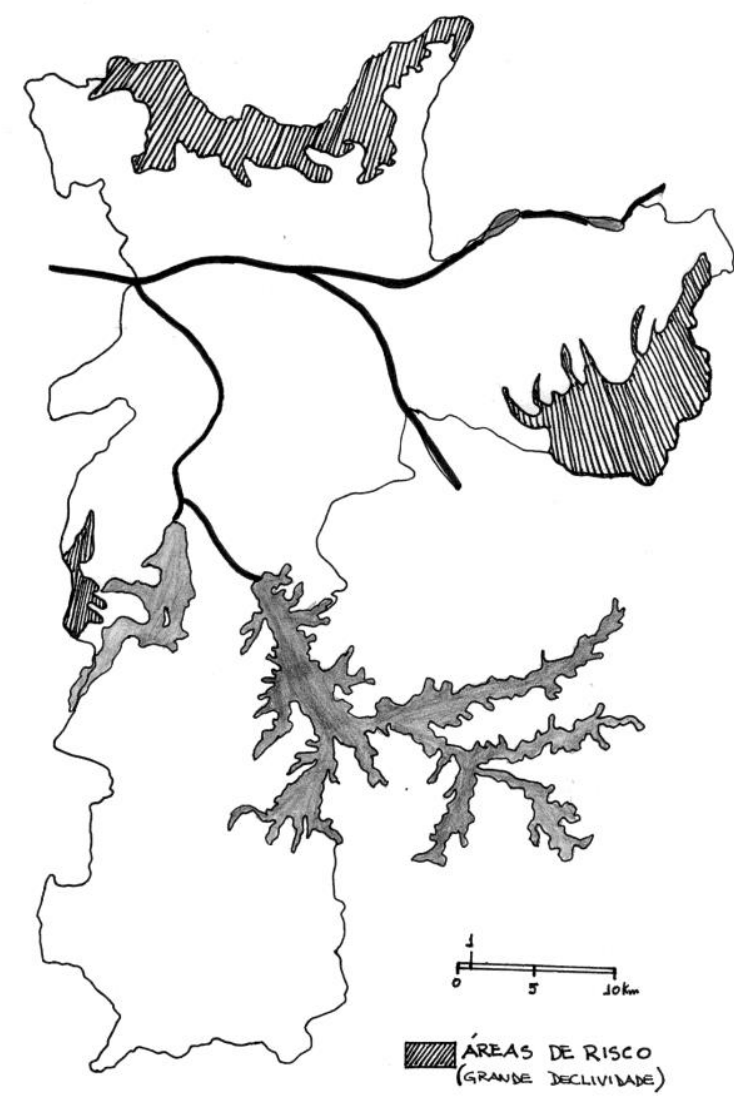

para 763 em 1980 e atingindo 1592 em 1987.", também caracteriza as vítimas em potencial, que são as populações das ocupações irregulares, "Na maioria dos casos, estas áreas são ocupadas desordenadamente por favelas e caracterizam-se pela precariedade ou ausência dos serviços de infra-estrutura urbana e irregularidade jurídica da posse dos terrenos".

\subsubsection{Implicações na Higiene Ambiental de São Paulo}

Caracterização dos aspectos de Higiene Ambiental, em relação à cidade de São Paulo, nos quais a atuação do Arquiteto e Urbanista direta ou indiretamente interfere.

57 FIGUEIREDO, Ricardo B. - Engenharia Social: soluções para áreas de risco, São Paulo, Makron Books, 1994. (p.7 e 14) 


\subsubsection{Iluminação}

A iluminância difusa do céu em São Paulo, adotada como aclaramento de referência em um plano horizontal livre de obstruções, é $11.000 l u x^{58}$. Estudos mais recentes ${ }^{59}$ demonstram, para São Paulo, levando-se em conta os períodos de nebulosidade, que em $99 \%$ do ano temos pelo menos 2.000 lux, em $81 \%$ do ano 10.000 lux e $72 \%$ do ano podemos contar com 15.000lux.

As superfícies das construções urbanas paulistanas são claras e têm boa reflexão. As necessidades mínimas de iluminância nos espaços livres são: circulação em geral 100lux, recreação 150lux, esportes 200lux e leitura 300lux (op.cit. item 2.4.1). Como aproximação inicial, esses fatores demonstram condições de iluminação nos espaços abertos, adequadas para as atividades externas. Nos recuos laterais entre edifícios ou sob árvores, que são situações em que a área de céu visível é menor, o aclaramento dependerá da cor e reflexão das superfícies, sendo necessário fazer medições e avaliações locais.

Em termos arquitetônicos, sob o aspecto iluminação, recomenda-se barrar o Sol direto que, pelo excesso de luminosidade, pode ofuscar e dificultar a visão. Recomenda-se também que as edificações continuem a ser produzidas e mantidas com superfícies claras, que é uma das boas características paulistanas. Várias cidades européias são escuras e até cidades americanas como Buenos Aires, Montevidéu, Nova York, Chicago ou Boston, são mais escuras que São Paulo. A afirmação, tão divulgada, de que nossa cidade é cinza, tem maior causa na poluição e sujeira do que na cor e reflexão dos edifícios.

\subsubsection{Ruídos}

As fontes sonoras têm origens e abrangências locais. Apesar disso, o relevo de morfologia bastante acidentada, com diversas compartimentações, pode contribuir para restringir ou atenuar a propagação dos ruídos.

As fontes de ruídos em São Paulo, assim como em qualquer outra grande cidade, têm sua origem em diversos tipos de fontes: a) veículos: automóveis, caminhões, ônibus, motocicletas, trens, aviões, coletor de lixo, sirenes e alto falantes (entregador de gás, pamonha, produtos de limpeza, etc.); b) meios de produção: obras civis, reformas e indústrias em geral; c) aglomerações do setor terciário da economia:

\footnotetext{
58 CHICHIERCHIO, Luiz Carlos - Manual Técnico de Iluminação Zenital, São Paulo, ColorPlast, sem data. p.29.

59 ALUCCI, Márcia Peinado - Dimensionamento de Aberturas e Otimização da lluminação Natural na Arquitetura, São Paulo, Universidade Ibirapuera, (Relatório de pesquisa 2000, edição no prelo) Cap.3.
} 
casas de diversão, escolas, clubes, playgrounds, bares, feiras livres, lanchonetes e igrejas.

Para determinar o grau de incômodo de um ruído, é necessário levar em consideração: suas características físicas (Intensidade, Altura e Duração), o tipo de atividade e a adaptabilidade da pessoa (idade, estado físico e psicológico). As pessoas tendem a admitir ruídos contínuos, mais do que ruídos pulsantes. Uma proporção significativa de pessoas se adapta a ruídos habituais, é o caso de moradores próximo a grandes avenidas, linhas férreas ou aeroportos.

Em acústica, o ideal é controlar o ruído na fonte ou, se possível, eliminá-la. Como isso nem sempre é possível, sugerimos ao projetista: a) setorizar as áreas, procurando agrupar as atividades de mesmos níveis sonoros; b) instalar barreiras acústicas; c) escolher materiais isolantes ou absorventes para as superfícies; d) orientar os edifícios para que não aumentem a reverberação dos sons.

\subsubsection{Odores e Fumaça}

Os cheiros, as emanações e as fuligens, embora tenham origens localizadas, dependendo da intensidade e direção dos ventos, podem se propagar por grandes distâncias. Alguns exemplos: a indústria de papel e celulose instalada em Suzano desprende vapores e odores desagradáveis que carreados pelos ventos, seguindo as sendas do relevo, afetam as regiões circunvizinhas como: Poá, São Miguel Paulista, Mogi das Cruzes, Guaianazes ou Ferraz de Vasconcelos. No verão, as águas semi-estacionárias e poluídas do rio Pinheiros têm péssimo odor. Como o rio é sinuoso, há trechos de suas margens onde os cheiros são intensos e intervalos em que são quase imperceptíveis. Até o final da década de 1980, no bairro da Saúde a metalúrgica Aliperti liberava fumaça alaranjada com forte mau cheiro, costumeiramente levada pelo vento, que, seguindo o vale do riacho do Ipiranga, ia prejudicar a vila Mariana ou o Ipiranga.

A compartimentação topográfica direciona os ventos tendo significativa participação na abrangência e dispersão dos poluentes.

O espectro olfativo em São Paulo é muito amplo. Caminhões e ônibus espalham fumaça e cheiro de diesel; automóveis emitem odores de catalisadores, de álcool, de gás e de gasolina; rios, córregos, valetas, galerias, fezes de animais, sarjetas e montes de lixo exalam mau cheiro; padarias, churrascarias, pizzarias, docerias, torrefações de café, feiras livres e mercados liberam um caleidoscópio de odores. 
Muitas vezes chegam a ser extremamente desagradáveis, propagam-se no ar e não há barreiras eficientes. A solução está em eliminar as origens, evitando a produção dos cheiros e, se não for possível, higienizar as fontes, projetar adequadamente os trajetos dos rejeitos que geram odores e adequar os destinos finais.

\subsubsection{Calor}

A poluição térmica ou aquecimento da metrópole paulistana tem três tipos de origens principais: a) calor da radiação solar, absorvido pelas características físicas dos componentes urbanos (materiais, cores, formas e orientações); b) calor gerado nos processos de funcionamento da metrópole (produção, transformações e consumo de energias); e c) calor retido pela atmosfera (efeito estufa causado pela poluição e pelo vapor d'água).

Dentre as três causas do aquecimento urbano, os profissionais ligados ao projeto podem colaborar para solucionar as duas primeiras, já que o problema do efeito estufa é de todos e a contribuição para reduzi-lo tem que ser do cidadão e não somente do profissional.

Para reduzir a entrada de radiação solar, é conveniente usar materiais com baixos coeficientes de absorção $(\alpha)^{60}$, os quais dependem da cor do material, principalmente nas superfícies Horizontais e nas orientadas para Oeste e Sul, que recebem maior insolação nos períodos e estações mais quentes. Outra forma, é usar árvores para sombrear as superfícies. Nossas medições indicam, em piso cimentado, temperaturas $5^{\circ} \mathrm{C}$ menores na sombra do que ao Sol.

Quanto à geração e consumo de energia, é fundamental reduzir o consumo desnecessário; por exemplo, construir um edifício tipo caixa fechada, sem janelas, desprezando a iluminação natural, usando iluminação artificial de dia é desperdício. Basicamente lidamos com quatro tipos de energia: mecânica, elétrica, luminosa e térmica; constantemente transformamos umas nas outras e a cada transformação perde-se calor para o ambiente. $O$ ideal é utilizar fontes que gerem diretamente a energia necessária e aumentar a eficiência dos equipamentos.

60 Exemplos de coeficientes de absorção $(\alpha)$ : tijolo ou telha vermelhos $=0,80$; tijolo ou telha amarelos $=0,50$; alumínio ou cromo polidos $=0$, 30. (fonte: KOENIGSBERGER, p.295) 


\subsubsection{Gases e Material Particulado}

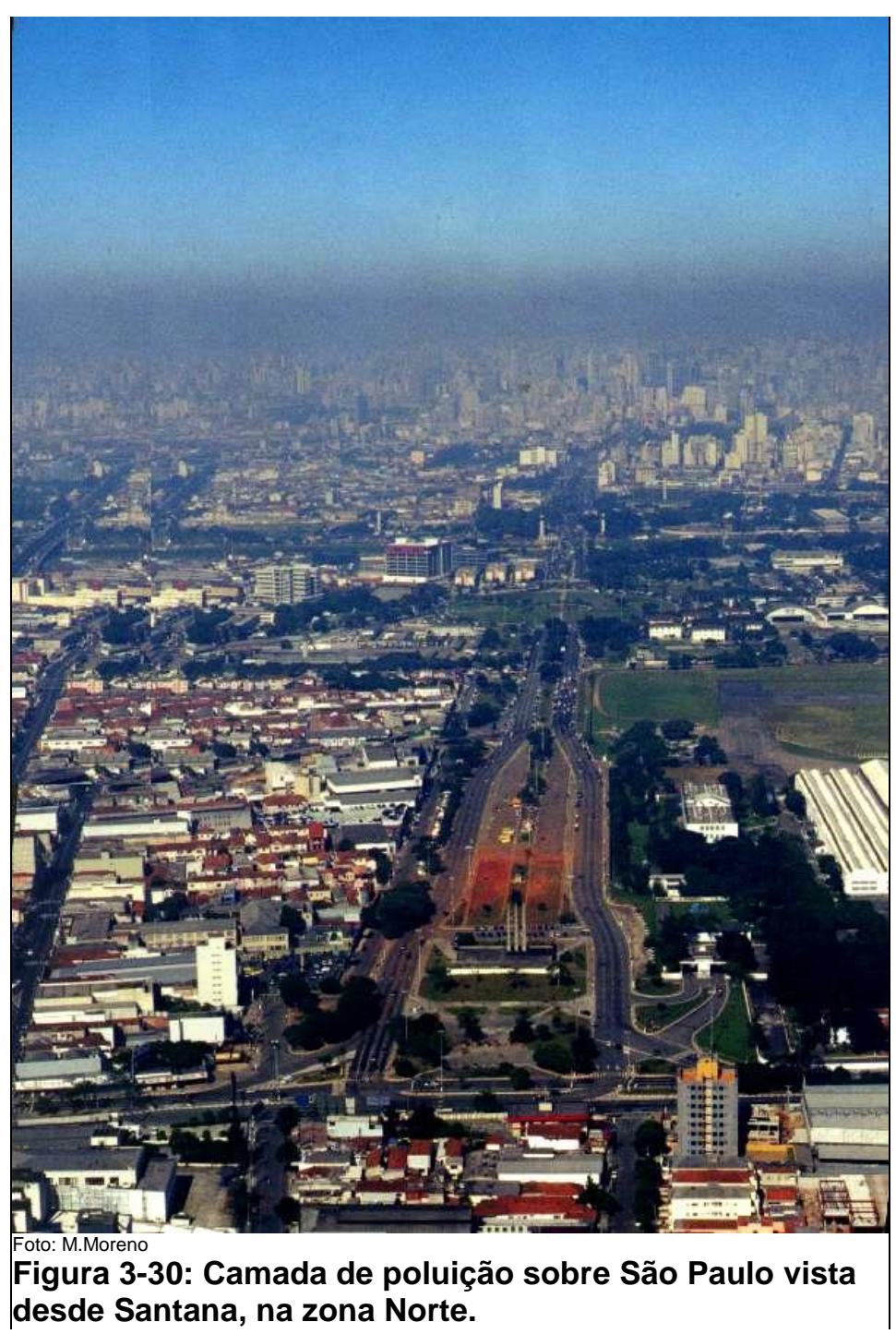

No município de São Paulo, segundo a CETESB (op.cit. 42), $98 \%$ do $\mathrm{CO}, 97 \%$ dos $\mathrm{HC}$ e $\mathrm{NO}_{x}, 85 \%$ do $\mathrm{SO}_{2}$, e $90 \%$ do $\mathrm{PI}^{61}$, são produzidos por veículos, o que falta para $100 \%$ é produzido por indústrias. Para reduzir esses problemas, os profissionais podem planejar a cidade de maneira a diminuir os deslocamentos, reduzindo o uso de veículos individuais, além de aprimorar o transporte publico não poluente.

O traçado e a qualidade das vias de circulação afetam muito a poluição. Por exemplo, um automóvel que tem que parar constantemente, por lombadas, valetas, buracos, semáforos, congestionamentos, queima mais combustível e libera mais gases. Cada vez que freia, libera fuligem e material particulado dos freios (que contém amianto e é cancerígeno). E quando arranca, além de produzir ruído mais intenso, libera partículas dos pneus. Como subsídio, podemos acrescentar que em cidades onde 0 calçamento é bom e o tráfego flui, os desgastes das suspensões, dos freios, dos pneus, o consumo de combustíveis e a poluição gerada, são menores que em São Paulo.

${ }^{61} \mathrm{CO}=$ Monóxido de Carbono, $\mathrm{HC}=$ Hidrocarbonetos, $\mathrm{NO}_{\mathrm{x}}=$ Óxidos de Nitrogênio, $\mathrm{SO}_{\mathrm{x}}=$ Óxidos de Enxofre e PI = Partículas 


\subsubsection{Lixo e Sujeira}

Um exame das montanhas de sujeira ao longo das marginais do rio Tietê, resultantes do desassoreamento do rio, mostra que o material retirado é muito mais do que terra, esgotos ou resíduos trazidos pela chuva. O que mais se encontra é lixo. Tanto ou mais do que os efluentes domésticos ou industriais, a poluição dos corpos d'água é causada pelo lixo. Este fato mostra que, culturalmente, a população como um todo, percebe os córregos e rios como lixeiras. Conseqüentemente, São Paulo é uma cidade suja e o motivo principal é que a população, independentemente da classe sócio-econômica, pouco se interessa em mantê-la limpa. Embora as pessoas se preocupem em limpar suas moradias, por problemas culturais ou por deficiências educacionais, não se observa o mesmo interesse com os espaços públicos, não sentem a cidade pertencendo-lhes, não há senso de coletividade, e nem consciência das conseqüências, para a qualidade de vida e a saúde.

\subsubsection{Desconforto Cinestésico}

São Paulo não é uma cidade plana e

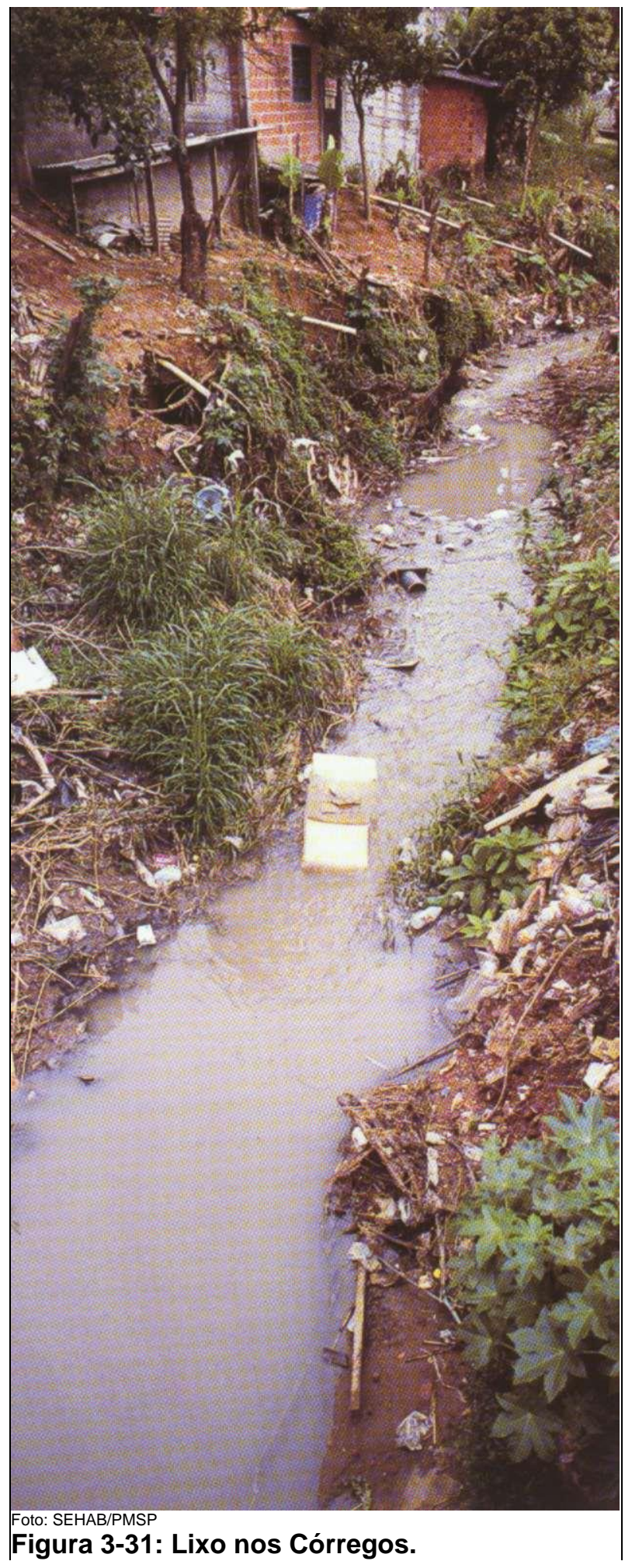
isso é enfatizado constantemente aos pedestres pelos desníveis, degraus e todo tipo de irregularidades nos caminhos. É comum vermos pessoas preferirem caminhar pelas ruas, ao invés de usar as calçadas. São muitos os empecilhos: obstáculos, como postes para rede elétrica, para iluminação, para telefones públicos, para 
sinalização; obstruções maiores, como lixeiras, bancas de jornal, caixas de correio, portões que avançam no passeio, floreiras, guaritas, abrigos de ônibus e toda sorte de instalações para o comércio ambulante; irregularidades no traçado e dimensionamento, como degraus, desníveis, canaletas, afloramentos de raízes, inclinações excessivas e dimensões insuficientes. Existe claramente, desinteresse e ou omissão em relação às calçadas, que não parecem ter sido desenhadas para as pessoas. Seus idealizadores parecem desconhecer os princípios mínimos de acessibilidade universal $^{62}$. Todos esses problemas podem ser equacionados e solucionados pelos projetistas.

\subsubsection{Implicações Climatológicas em São Paulo}

\begin{tabular}{|c|c|c|c|c|c|c|}
\hline \multirow[b]{2}{*}{ Hora } & \multicolumn{3}{|c|}{ Verão } & \multicolumn{3}{|c|}{ Inverno } \\
\hline & $\operatorname{TBS}\left({ }^{\circ} \mathrm{C}\right)$ & UR (\%) & $\mathrm{RS}\left(\mathrm{Wh} / \mathrm{m}^{2}\right)$ & $\operatorname{TBS}\left({ }^{\circ} \mathrm{C}\right)$ & UR (\%) & $\operatorname{RS}\left(\mathrm{Wh} / \mathrm{m}^{2}\right)$ \\
\hline 1 & 21,7 & 80 & 0 & 11,4 & 82 & 0 \\
\hline 2 & 21,2 & 83 & 0 & 11,0 & 85 & 0 \\
\hline 3 & 20,6 & 86 & 0 & 10,5 & 87 & 0 \\
\hline 4 & 20,4 & 87 & 0 & 10,3 & 88 & 0 \\
\hline 5 & 19,5 & 92 & 0 & 9,6 & 92 & 0 \\
\hline 6 & 19,0 & 95 & 21 & 9,2 & 95 & 0 \\
\hline 7 & 19,9 & 90 & 181 & $9 ., 9$ & 91 & 30 \\
\hline 8 & 22,0 & 79 & 365 & 11,6 & 81 & 245 \\
\hline 9 & 24,3 & 68 & 529 & 13,4 & 72 & 461 \\
\hline 10 & 26,3 & 60 & 656 & 15,0 & 65 & 630 \\
\hline 11 & 28,2 & 54 & 736 & 16,5 & 59 & 738 \\
\hline 12 & 29,5 & 50 & 764 & 17,5 & 56 & 775 \\
\hline 13 & 30,0 & 49 & 736 & 17,9 & 54 & 738 \\
\hline 14 & 31,2 & 46 & 656 & 18,8 & 51 & 630 \\
\hline 15 & 31,4 & 45 & 529 & 19,0 & 51 & 461 \\
\hline 16 & 30,9 & 47 & 365 & 18,6 & 52 & 245 \\
\hline 17 & 30,4 & 48 & 181 & 18,2 & 53 & 30 \\
\hline 18 & 29,5 & 50 & 21 & 17,5 & 56 & 0 \\
\hline 19 & 25,7 & 62 & 0 & 14,5 & 67 & 0 \\
\hline 20 & 24,5 & 67 & 0 & 13,5 & 72 & 0 \\
\hline 21 & 23,5 & 72 & 0 & 12,7 & 75 & 0 \\
\hline 22 & 22,3 & 77 & 0 & 11,8 & 80 & 0 \\
\hline 23 & 22,7 & 75 & 0 & 12,1 & 78 & 0 \\
\hline 24 & 22,1 & 78 & 0 & 11,7 & 81 & 0 \\
\hline \multicolumn{7}{|c|}{ TBS $\left({ }^{\circ} \mathrm{C}\right)$ Temperatura de Bulbo Seco; UR (\%)Umidade Relativa; RS $\left(\mathrm{Wh} / \mathrm{m}^{2}\right)$ Radiação Solar Global em plano horizontal. } \\
\hline
\end{tabular}

A cidade de São Paulo está sujeita a um Clima Tropical modificado pela altitude, com verões muito úmidos e chuvosos. Por influência da urbanização, os contrastes

\footnotetext{
$62 \mathrm{Na}$ ABNT, encontramos sete normas que tratam de acessibilidade. Uma delas se aplica aos espaços em geral; é a NBR9050/94 (NB833): Acessibilidade de pessoas a edificações, espaço, mobiliário e equipamento urbano.
} 
climáticos estão se acentuado, as chuvas de verão são mais intensas e os invernos estão tendendo a serem cada vez mais secos.

A tabela 3.2 apresenta os dias típicos de verão e de inverno para projeto, isto é, no Verão $90 \%$ do período tem temperaturas máximas diárias menores ou iguais ao dia típico. Inverno: $90 \%$ do período tem temperaturas mínimas diárias maiores ou iguais ao dia típico.

\subsubsection{Insolação}

A orientação de vertentes relaciona o relevo com a insolação. No caso paulistano, as encostas voltadas para o Norte e para o Leste têm melhor insolação de manhã e também nas estações frias, além de receberem menos Sol nos períodos quentes. Outro aspecto favorável é que ficam protegidas dos ventos úmidos que sopram de Sul e Sudeste.

\subsubsection{Ventos}

Em São Paulo predominam os ventos Alísios de Sudeste, que são lentos, com velocidades geralmente abaixo de $5 \mathrm{~m} / \mathrm{s}$. Em virtude da proximidade do oceano, costumam ser úmidos; sopram de Sudeste e percorrem os vales dos rios: Aricanduva, Tamanduateí e Pinheiros no sentido sudeste - noroeste, até serem barrados pela Serra da Cantareira. São muito freqüentes, principalmente no inverno, as frentes frias que ficam semi-estacionárias, barradas pelo relevo, e provocam inversões térmicas. Como conseqüência, se houver poluição, ela se acumulará ao longo do Tamanduateí e no sopé da serra sobre os bairros: vila Prudente, Moóca, Brás, Pari, Centro,Tatuapé e Vila Maria. Os

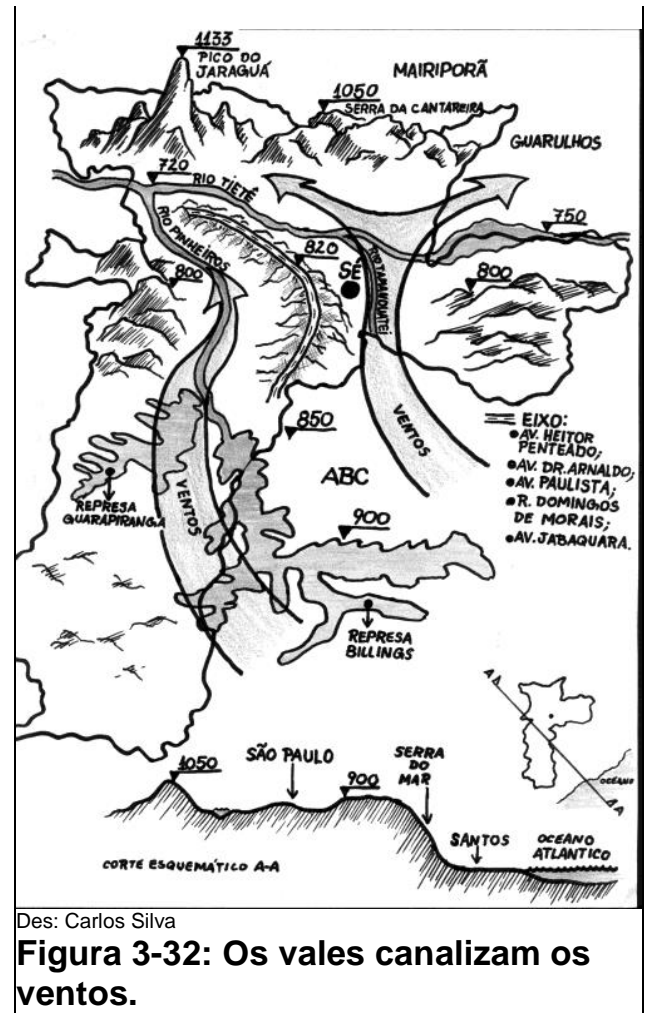
ventos percorrem os vales levando os poluentes e também umidade. No caso paulistano, as maiores superfícies de água, que são as represas Billings e 
Guarapiranga estão a montante ${ }^{63}$ do rio Pinheiros, e os ventos que percorrem seu vale, por terem passado sobre as represas, são mais úmidos.

\subsubsection{Umidade}

As Umidades Relativas do ar, médias mensais, em São Paulo têm valores acima de $70 \%$ nos meses de setembro a maio, podendo ser considerado período úmido, e valores menores que $70 \%$ no restante do ano, que corresponde aos meses de inverno. Nos meses de junho, julho e agosto, as Umidades Relativas do ar, mínimas mensais, têm valores inferiores a 55\%, o que significa ar seco.

A pluviosidade média mundial é da ordem de $1000 \mathrm{~mm} / \mathrm{ano}^{64}$, o que equivale aproximadamente a $83 \mathrm{~mm} / \mathrm{mês}$. O conceito de deserto se aplica a regiões com precipitações abaixo de $250 \mathrm{~mm} / \mathrm{ano}$ ou $20 \mathrm{~mm} / \mathrm{mês}$. Baseando-se nessas referências, podemos dizer que as precipitações paulistanas são altas porque chegam a $1500 \mathrm{~mm} / \mathrm{ano}$, com meses chuvosos tendo médias mensais ${ }^{65}$ de: novembro $188 \mathrm{~mm}$, dezembro $206 \mathrm{~mm}$, janeiro $251 \mathrm{~mm}$, fevereiro $235 \mathrm{~mm}$ e março $177 \mathrm{~mm}$. Os meses com menos chuvas são: junho $49 \mathrm{~mm}$, julho $45 \mathrm{~mm}$ e agosto $38 \mathrm{~mm}$.

Apesar de São Paulo ter relevo ondulante, a declividade do rio Tietê é mínima. De Mogi das Cruzes até a divisa com Osasco, percorre $40 \mathrm{~km}$ e desce da cota $765 \mathrm{~m}$ para $720 \mathrm{~m}$, ou seja, apenas $45 \mathrm{~m}$. O mesmo ocorre com o rio Pinheiros, que é plano no trecho entre a elevatória Traição e o Cebolão. As altas pluviosidades combinadas com pequenas declividades dos rios são condições naturais para que as águas ocupem as várzeas nos meses mais chuvosos, mesmo sem considerar a impermeabilização provocada pela urbanização.

\subsubsection{Temperaturas}

Embora a tabela 3.2 mostre as situações nas estações opostas de inverno e verão, podemos observar que, em São Paulo predominam, na maior parte do tempo, temperaturas amenas, situando-se a média das máximas entre $19,0^{\circ} \mathrm{C}$ e $31,4^{\circ} \mathrm{C}$ e a média das mínimas entre $9,2^{\circ} \mathrm{C}$ e $19^{\circ} \mathrm{C}$.

\footnotetext{
63 Montante [De montar + nte.] Direção de onde correm as águas duma corrente fluvial. Para o lado da nascente (de um rio) [Antônimo: a jusante.] Enchente da maré; maré alta. [Antônimo: vazante.] Arquitetura: Qualquer peça vertical de sustentação que, numa estrutura, não possa ser considerada coluna ou pilastra.

64 Entendemos os Milímetros de chuva como sendo a altura que a água teria se não se infiltrasse, não escoasse e não evaporasse.

65 Pluviosidades Médias mensais da década 1981 a1990, fornecidas pelo Instituto Astronômico e Geofísico da USP.
} 



\section{Análise da Qualidade Ambiental Local}

O objetivo principal destas análises é subsidiar as decisões de Arquitetos e Urbanistas, nos aspectos em que sua atuação afeta a qualidade ambiental dos espaços livres, ao projetar e implantar edifícios altos (verticalização). A intenção é contribuir para que o profissional do projeto incorpore esses conhecimentos ao plano do intuitivo, porque somente assim essas preocupações farão parte da dinâmica do processo criativo.

Estudou-se a maioria dos aspectos ambientais nos espaços livres de Moema e Higienópolis, embora tenhamos feito o reconhecimento dos espaços livres de dezessete áreas verticalizadas na cidade de São Paulo. Alguns itens da qualidade ambiental foram estudados para todas as áreas, como a morfologia, e a orientação das vertentes; outros que dependiam do acesso a áreas privadas ${ }^{66}$ ou da construção de maquetes que demandam tempo e recursos indisponíveis, foram estudados em pelo menos duas áreas. Por exemplo, as medições de iluminação, ruídos, ventos, temperaturas e umidade relativa, foram feitas em Higienópolis e Moema; e os estudos de insolação e ventilação foram feitos através das maquetes de Higienópolis e Perdizes.

No capítulo anterior, examinamos os elementos da qualidade ambiental que são afetados pelas atividades da sociedade como um todo e pela arquitetura e urbanismo em particular, mas que se manifestam em macro-escala, abrangendo áreas maiores e tendo um agravamento gradual ao longo de muito tempo, como é o caso do aquecimento urbano, dos teores de gases, de poeiras, odores, lixo, sujeira, permeabilidade, inundações e desbarrancamentos.

Neste capítulo, as análises estão centradas nos aspectos da qualidade ambiental, que são alterados de imediato pela materialização de intervenções arquitetônicas ou urbanísticas como: iluminação, ruídos, cinestesia e os elementos climáticos.

O profissional do projeto deve propiciar condições para que os espaços livres tenham qualidade ambiental, isto é, que os espaços sejam adequados a várias atividades e que também sejam estética e psicologicamente agradáveis e garantam conforto e salubridade.

66 O acesso aos edifícios é problemático; naqueles em que pudemos entrar, custou-nos muito tempo em negociações trabalhosas com trocas de ofícios e aprovações de síndicos e zeladores. 


\subsection{Iluminação}

Os estudos de casos, para iluminação, foram feitos nos seguintes locais: a) bairro de Higienópolis, em percurso com treze pontos e b) bairro de Moema, em percurso com cinco pontos e nos espaços livres entre edifícios outros seis pontos.

Nas medições, utilizamos dois instrumentos: o "Espelho do céu" que é uma versão da câmara de Robin Hill (op.cit. ${ }^{16)}$ desenvolvida por nós e que está explicada no capítulo 5; e um luxímetro, modelo LX-101, marca Lutron.

\subsubsection{Higienópolis}

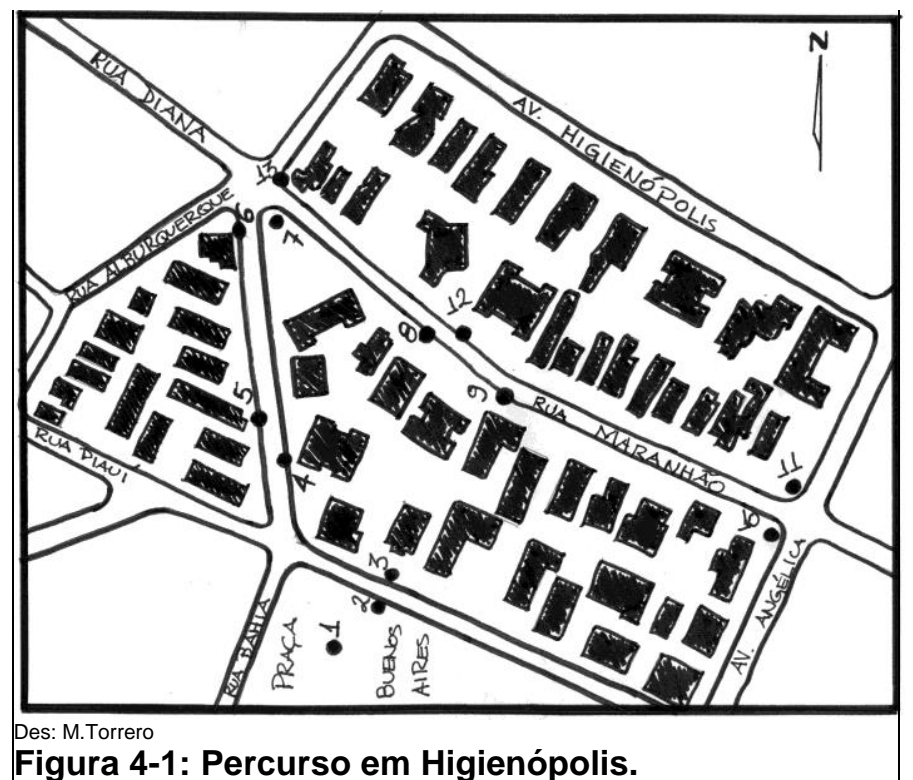

Figura 4-1: Percurso em Higienópolis.
As medições foram feitas no dia 05 de julho de 2000 , entre $10 \mathrm{~h}$ e $13 \mathrm{~h}$, quando o dia estava claro, com muitas nuvens e o Sol encoberto.

O percurso de treze pontos foi iniciado na praça Buenos Aires e prosseguiu pela rua Piauí, rua Bahia, rua Maranhão, av. Angélica e terminando novamente na rua Maranhão.

O trajeto tem vegetação de grande

porte, com árvores que excedem três pavimentos $(10 \mathrm{~m}$ a $15 \mathrm{~m})$ e em vários trechos as copas se fecham sobre as ruas, mantendo uma parte do céu obstruído e, conseqüentemente, reduzindo a iluminação.

As iluminâncias obtidas, em cada ponto do percurso, no plano horizontal, a um metro de altura, foram:

\begin{tabular}{|c|c|c|c|c|c|c|c|c|c|c|c|c|c|}
\hline \multirow[b]{2}{*}{ Ponto } & \multirow{2}{*}{$\begin{array}{c}\text { Praça } \\
\text { B.Aires } \\
01\end{array}$} & \multicolumn{2}{|c|}{ r. Piauí } & \multicolumn{3}{|c|}{ r. Bahia } & \multicolumn{3}{|c|}{ r. Maranhão } & \multicolumn{2}{|c|}{ Av. Angélica } & \multicolumn{2}{|c|}{ r. Maranhão } \\
\hline & & 02 & 03 & 04 & 05 & 06 & 07 & 08 & 09 & 10 & 11 & 12 & 13 \\
\hline$(\operatorname{lux})$ & 12800 & 11700 & 12200 & 2800 & 6800 & 7400 & 16500 & 13000 & 11000 & 16000 & 24200 & 11900 & 263 \\
\hline
\end{tabular}

Tabela 4-1: lluminâncias obtidas no percurso em Higienópolis.

Embora o céu estivesse muito encoberto e em alguns momentos tenha garoado, as iluminâncias excedem as necessidades. Como pode ser observado, a iluminância mínima foi de 2800lux, obtida no ponto 4 na rua Bahia, sob uma árvore. 
Considerando-se que ao ar livre, na calçada, ler é a atividade que mais exige luz, no mínimo 200lux, podemos afirmar que o valor excede em muito as necessidades.

Dentre as fotos obtidas com o "Espelho do céu", destacamos a do ponto 1, em meio a Praça Buenos Aires; o ponto 4 na rua Bahia, que teve o menor aclaramento ${ }^{67}$ do percurso; e o ponto 13, em que o céu estava mais aberto e obtivemos a maior iluminância do trajeto.

Considerando-se 10.000lux como a iluminância de referência disponível $81 \%$ do ano, na cidade de São Paulo (ver item 3.2.3.1), a foto que indica em projeção eqüidistante a porção visível do céu, sobreposta ao gráfico de distribuição de luz difusa, também traçado em projeção eqüidistante, teremos para cada ponto do trajeto a estimativa de iluminância que disporemos em pelo menos $81 \%$ do tempo.

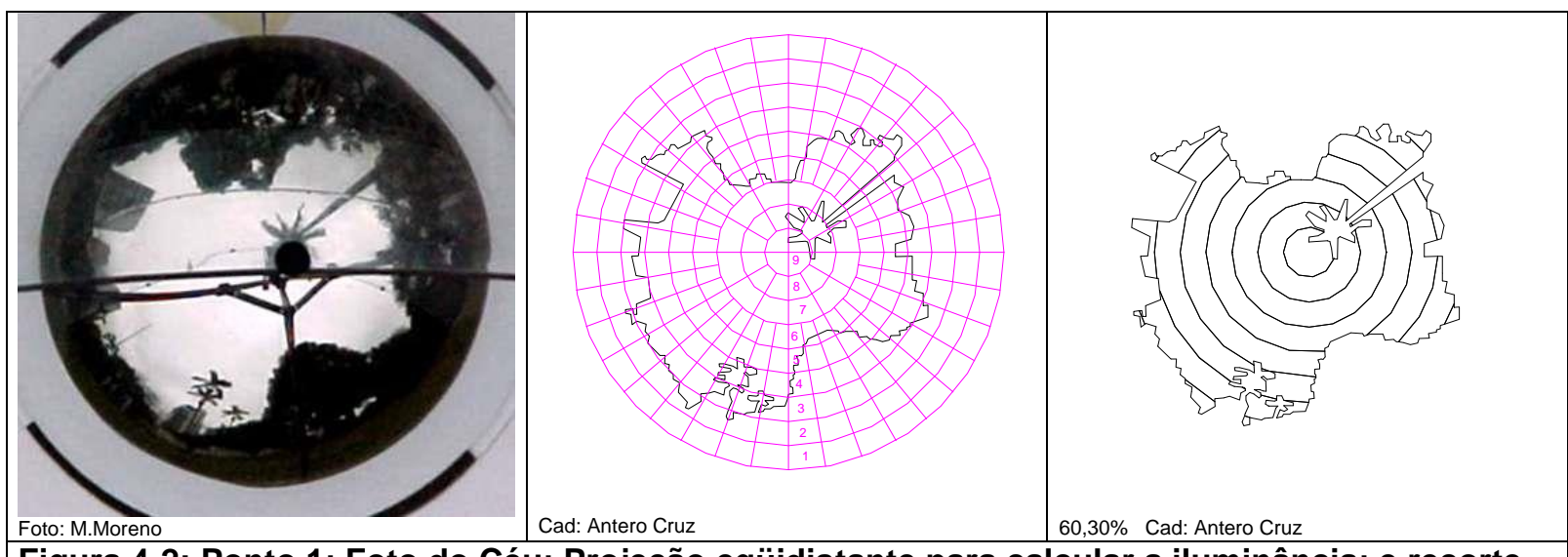

Figura 4-2: Ponto 1; Foto do Céu; Projeção eqüidistante para calcular a iluminância; e recorte do céu visível com porcentagem da iluminância total. No ponto 1, a iluminância é 6.030lux.
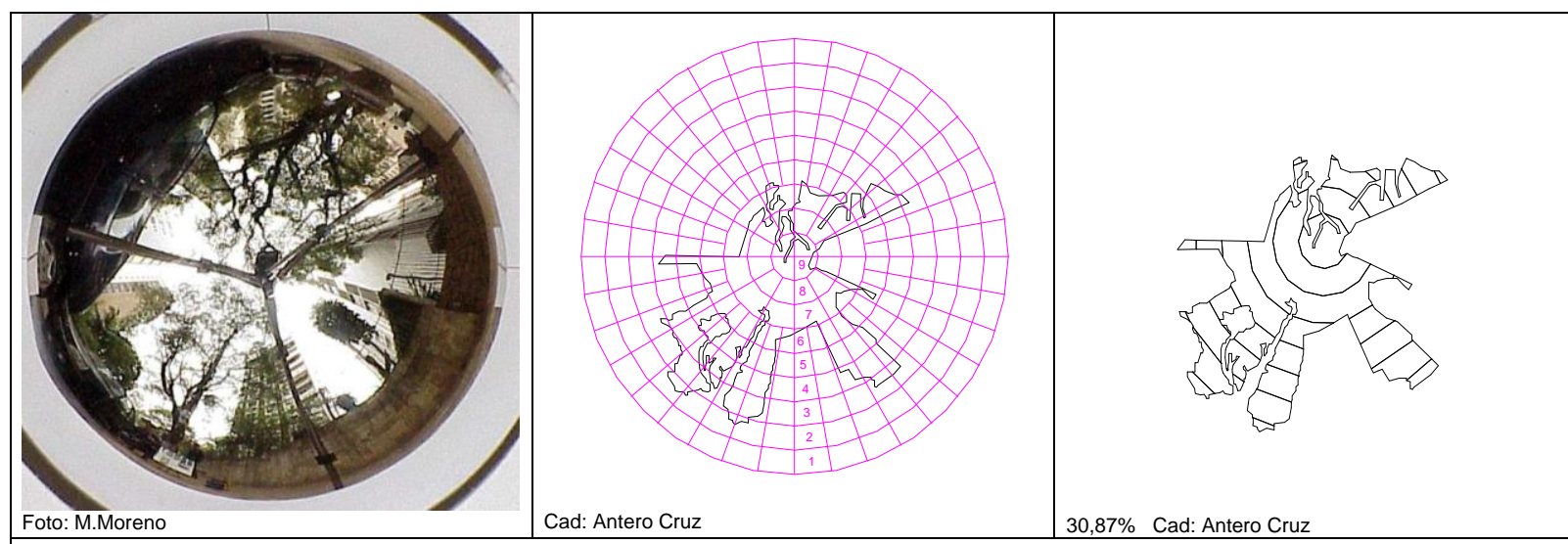

Figura 4-3: Ponto 4; Foto do Céu; Projeção eqüidistante para calcular a iluminância; e recorte do céu visível com porcentagem da iluminância total. No ponto 4, a iluminância é 3.087lux.

67 Aclaramento: Tornar claro; dar luz ou claridade a; iluminar, alumiar [De iluminar + mento.], Iluminação, iluminância: Fluxo luminoso incidente por unidade de área de uma superfície iluminada, (lux = lúmen $/ \mathrm{m}^{2}$ ). 

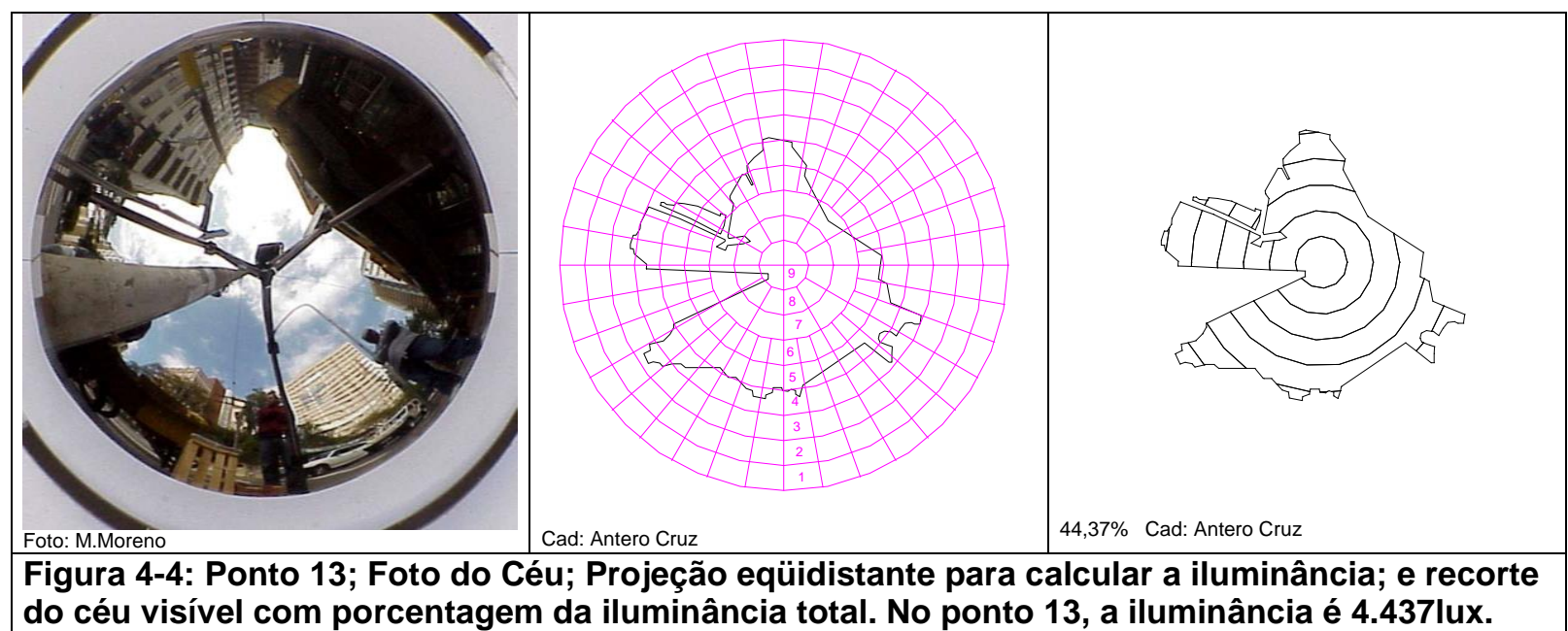

do céu visível com porcentagem da iluminância total. No ponto 13, a iluminância é 4.437lux.

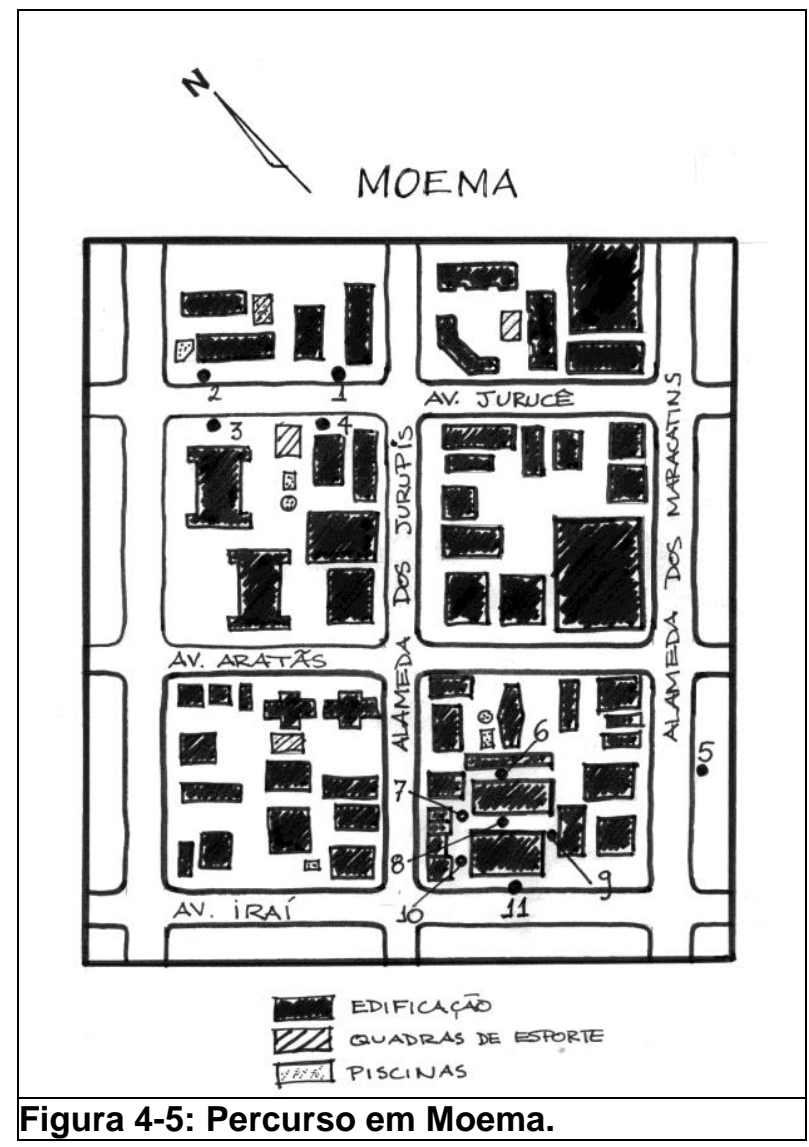

\subsubsection{Moema}

As medições foram feitas no dia 3 de janeiro de 2001, entre $11 \mathrm{~h} 30$ e $15 \mathrm{~h}$ quando o dia estava quente, ensolarado, o céu claro e sem nuvens.

Os onze pontos medidos estão em dois trajetos, sendo cinco na Av. Jurucê e Al. dos Maracatins e os outros seis nos espaços livres entre os edifícios situados na Av. Iraí 297. Toda a área está verticalizada e tem vegetação esparsa.

As iluminâncias obtidas, em cada ponto do percurso, no plano horizontal, a um metro de altura, foram:

\begin{tabular}{|c|c|c|c|c|c|c|c|c|c|c|c|}
\hline & \multicolumn{5}{|c|}{ Av. Jurucê e Al. dos Maracatins } & \multicolumn{6}{|c|}{ Espaços livres, internos, na Av. Irai, 297} \\
\hline Ponto & 01 & 02 & 03 & 04 & 05 & 06 & 07 & 08 & 09 & 10 & 11 \\
\hline (lux) & 3900 & 8500 & 12150 & 9500 & 85700 & 3200 & 14900 & 16500 & 18500 & 4400 & 38700 \\
\hline
\end{tabular}

No percurso externo, escolhemos o ponto1, por ter a menor iluminância e o ponto 5 por ter a componente Solar que eleva a iluminância em demasia. No percurso 
interno, a iluminância mais baixa ocorre no ponto 6 , situado em um recuo de $2 \mathrm{~m}$ entre dois edifícios de 4 pavimentos e a maior no ponto 11 que está no recuo de frente, menos obstruído.
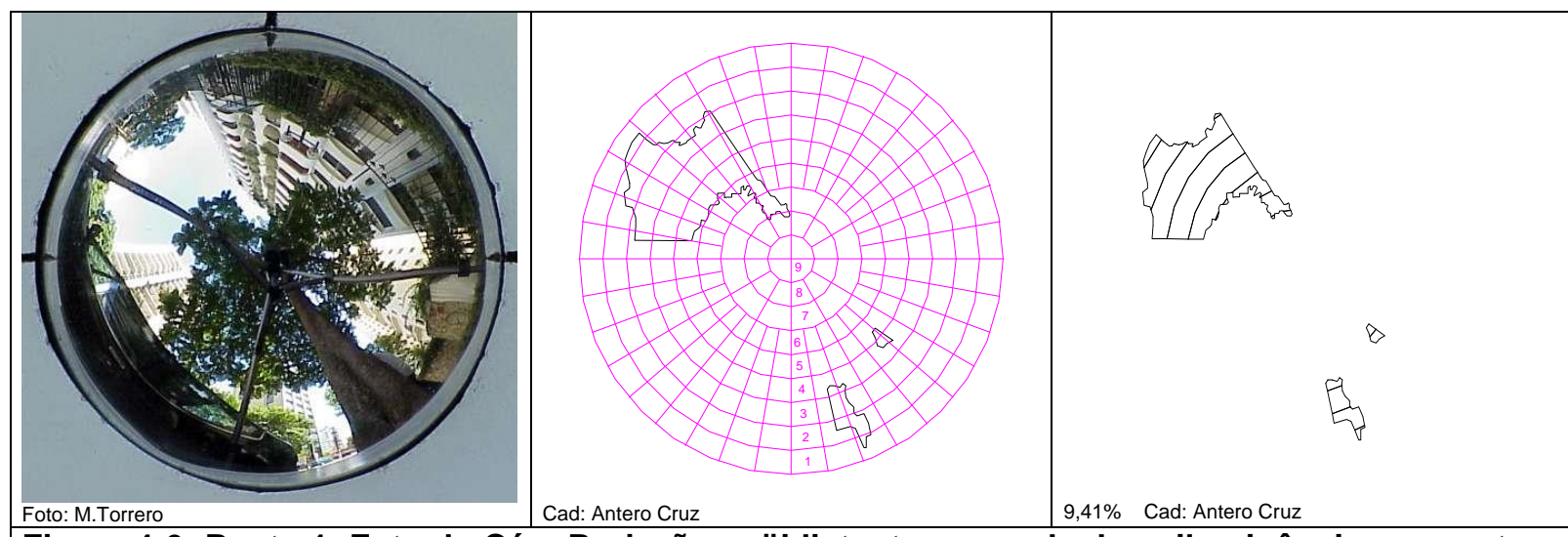

Figura 4-6: Ponto 1; Foto do Céu; Projeção eqüidistante para calcular a iluminância; e recorte do céu visível com porcentagem da iluminância total. No ponto, 1 a iluminância é 9.410lux.
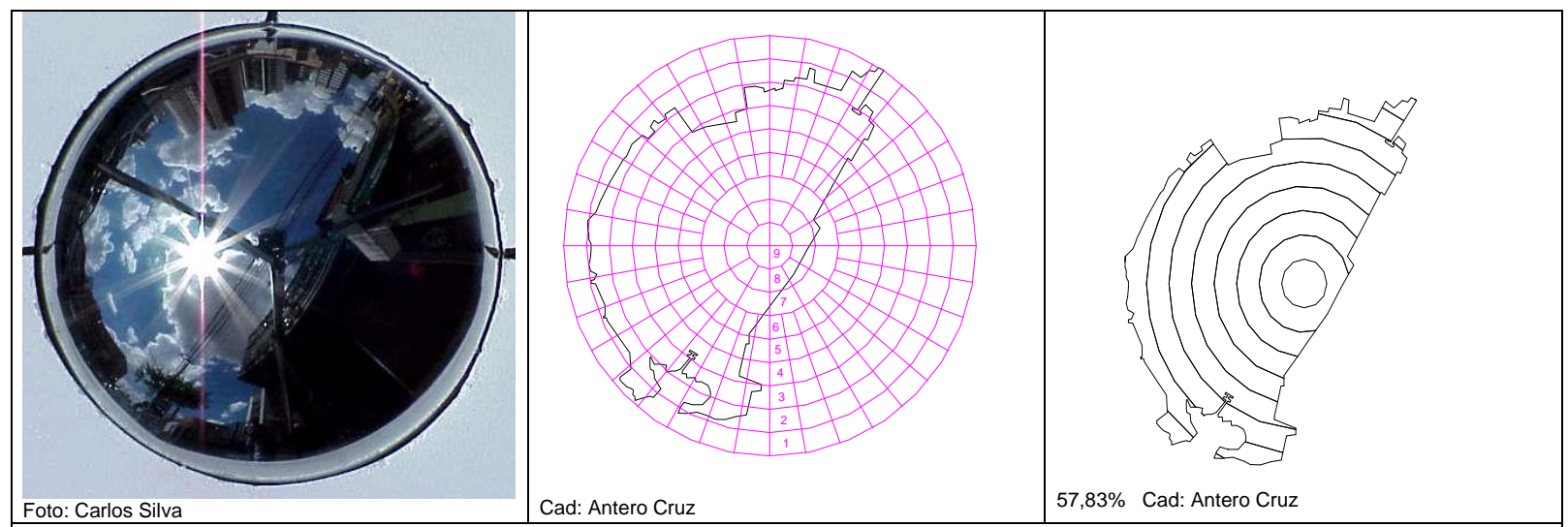

Figura 4-7: Ponto 5; Foto do Céu; Projeção eqüidistante para calcular a iluminância; e recorte do céu visível com porcentagem da iluminância total. No ponto 5 , a iluminância é 57.830 lux.
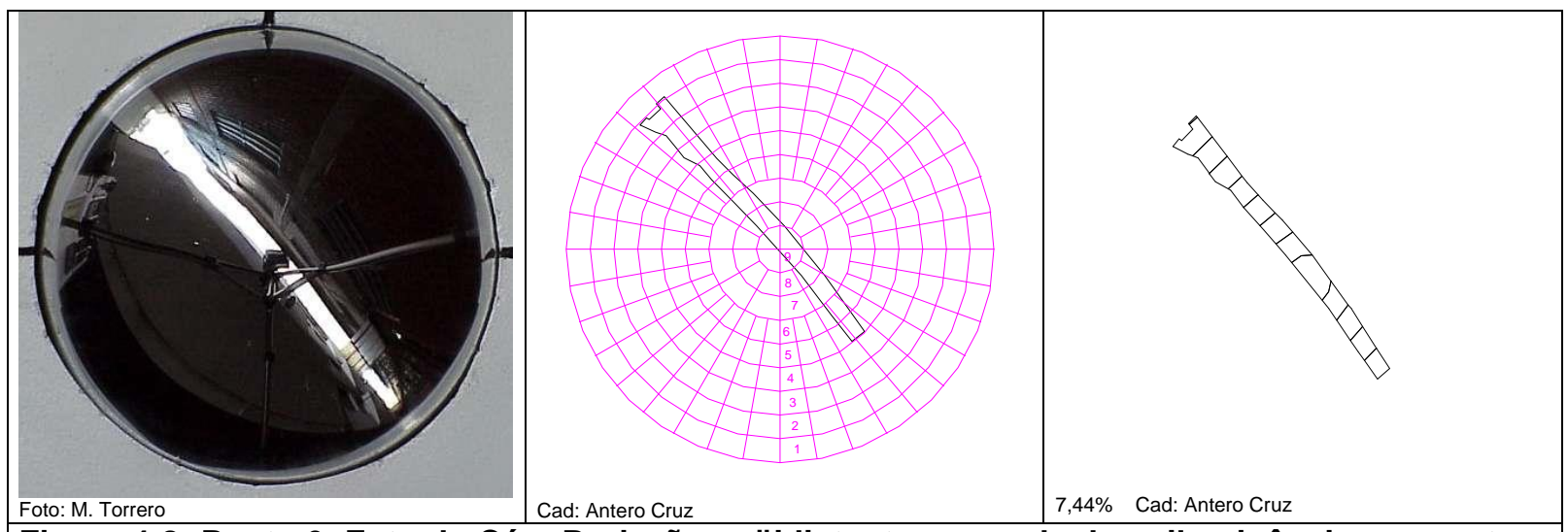

Figura 4-8: Ponto 6; Foto do Céu; Projeção eqüidistante para calcular a iluminância; e recorte do céu visível com porcentagem da iluminância total. No ponto 6 , a iluminância é 7 .440lux. 


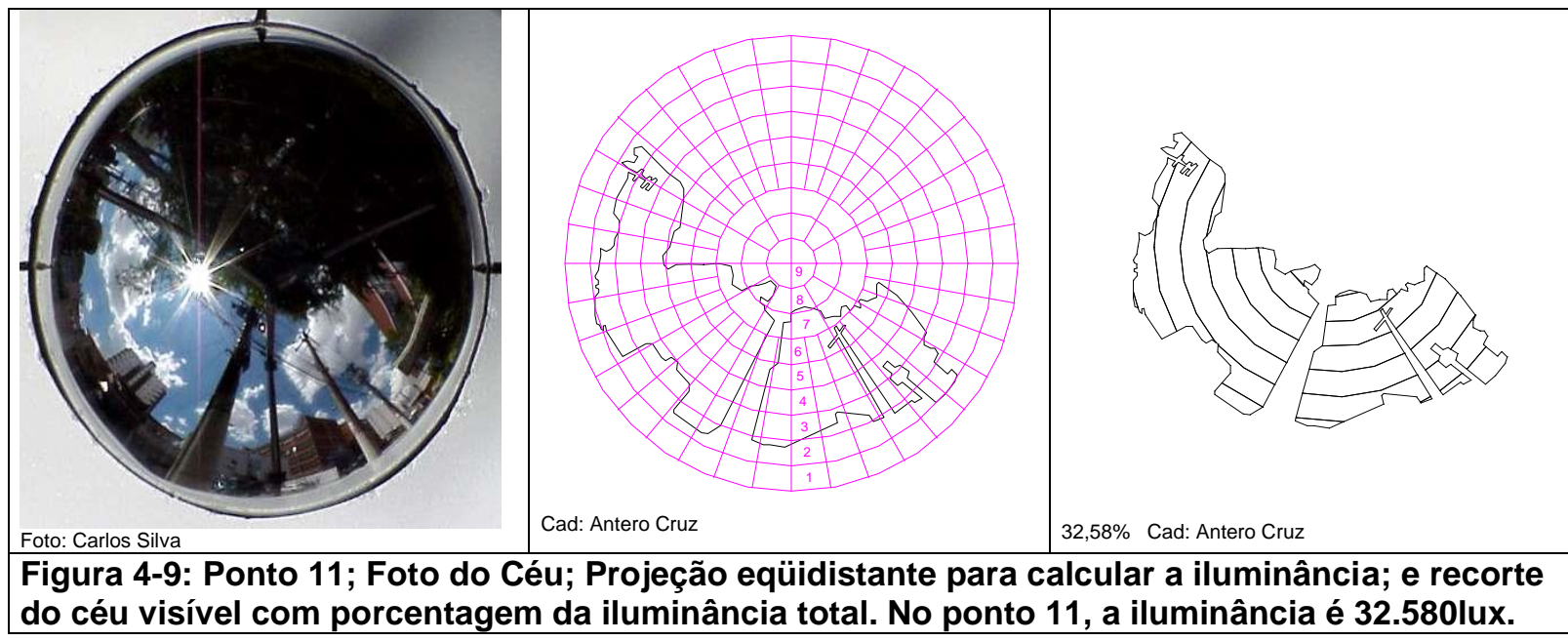

\subsubsection{Recomendações}

Normalmente, o aclaramento fornecido pela abóbada celeste na cidade de São Paulo, excede as necessidades para as atividades habituais desenvolvidas nos espaços livres, mesmo sob as sombras de árvores ou recuos estreitos. Esses locais terão problemas estéticos ou psicológicos por impedir que se veja o céu, ou problemas de falta de insolação, mas apesar de tudo isso, a iluminação para as atividades cotidianas é suficiente.

Providenciar uma boa reflexão das superfícies ajuda a distribuir melhor a iluminância, por isso é conveniente que as superfícies sejam claras. Por exemplo, o ponto 6 do percurso em Moema, distribuiria melhor a pouca iluminância disponível se as paredes fossem claras.

Outros problemas que podem ocorrer são: o contraste, que é a diferença de brilho ${ }^{68}$ entre as superfícies dos objetos e não deve exceder a proporção 10:1; e o ofuscamento, que é a perturbação ou a perda de visibilidade causada pela dificuldade de adaptação a uma iluminância muito intensa ou a variação muito brusca dessa iluminância. Ambas as situações costumam ocorrer em dias de forte insolação e podem ser controladas com sombreamentos graduais como os conseguidos com os pérgolados ou vegetação de copa ampla e rala, não muito cheia.

\footnotetext{
68 Brilho é luminância, é brilhância. Razão entre a intensidade do fluxo luminoso emitido por uma superfície em uma dada direção e a área da superfície emissora projetada sobre um plano perpendicular à direção considerada; luminância; brilhância fotométrica. (candelas $/ \mathrm{m}^{2}$ )
} 


\subsection{Ruídos}

Os estudos de casos, dos ruídos, foram realizados simultaneamente aos de iluminação e seguiram os mesmos percursos: a) bairro de Higienópolis, em percurso com treze pontos e b) bairro de Moema, em trajeto com onze pontos.

Fizemos as medições do Nível Sonoro de Intensidade (NSI), em decibels na escala A (dBA), utilizando um decibelímetro Lutron, modelo SL-4001.

\subsubsection{Moema}

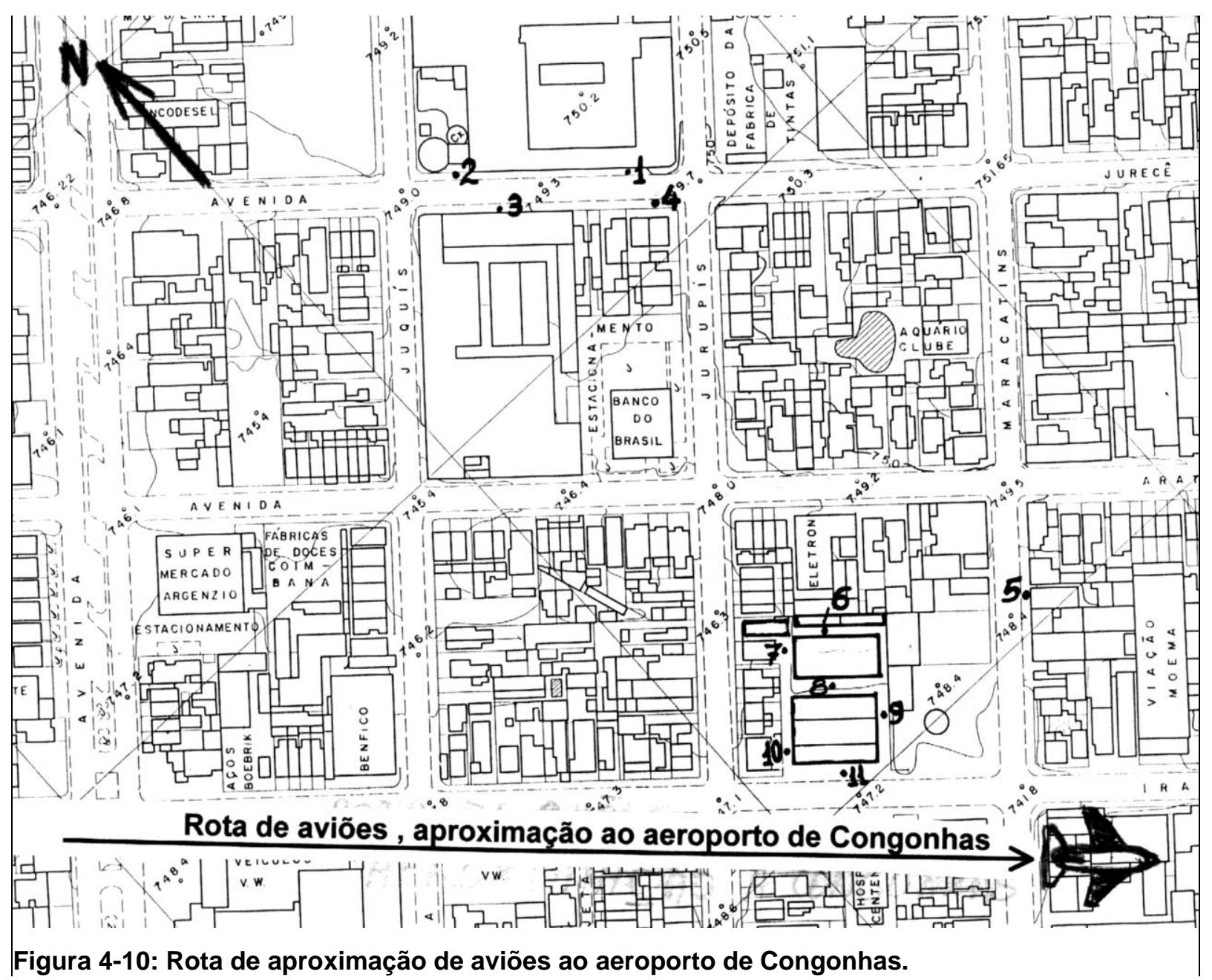

Dentre os bairros densamente verticalizados da capital paulista, Moema é o que apresenta os mais graves problemas acústicos por estar na rota de aproximação do Aeroporto de Congonhas, que é um dos mais movimentados do país. Além disso, a exemplo dos outros bairros, apresenta ruas com tráfego intenso. Em entrevistas com 
moradores, os tráfegos aéreo e terrestre são considerados como as piores fontes e, além dessas, relataram outras fontes como, alguns bares e casas de shows, que causam intensa movimentação de veículos à noite; de dia, as queixas recaíram sobre escolas de $1^{\circ}$ grau, que ficam próximas; e nos próprios edifícios as piores fontes são as quadras e os playgrounds.

As medições foram feitas no dia 3 de janeiro de 2001, entre $11 \mathrm{~h} 30$ e $15 \mathrm{~h}$.

Os onze pontos medidos estão em dois trajetos, sendo cinco entre a Av. Jurucê e a Al. dos Maracatins e os outros seis nos espaços livres entre os edifícios situados na Av. Iraí 297.

Os níveis sonoros obtidos, em cada ponto do percurso, a uma altura de 1,50m, foram:

\begin{tabular}{|c|c|c|c|c|c|c|c|c|c|c|c|}
\hline & \multicolumn{4}{|c|}{ Av. Jurucê e Al. dos Maracatins } & \multicolumn{4}{c|}{ Espaços livres, internos, na Av. Irai, 297} \\
\hline Ponto & 01 & 02 & 03 & 04 & 05 & 06 & 07 & 08 & 09 & 10 & 11 \\
\hline (dB A) & $\mathbf{8 7}$ & $\mathbf{7 9}$ & $\mathbf{6 2}$ & $\mathbf{5 9}$ & $\mathbf{7 4}$ & $\mathbf{6 4}$ & $\mathbf{5 9}$ & $\mathbf{5 6}$ & $\mathbf{6 0}$ & $\mathbf{6 1}$ & $\mathbf{5 6}$ \\
\hline
\end{tabular}

Tabela 4-3: Níveis Sonoros obtidos nos percursos em Moema.

As medições de intensidades acústicas devem ser feitas por períodos longos, de preferência por 24horas de um dia de atividade intensa normal e, assim, traçar perfis de variações. Como esse tipo de levantamento, que seria o ideal, não está ao nosso alcance, podemos considerar as 3 h30 que duraram nossas medições como significativas, pois foi realizado em horário de intensa atividade.

Pudemos observar que nas vias públicas, existe um ruído de fundo constante de aproximadamente $60 \mathrm{~dB}$ pontos 3 e 4 , com picos entre $75 \mathrm{~dB}$ e $90 \mathrm{~dB}$, causados pela passagem de algum veículo mais barulhento ou pela aproximação de aviões.

Nos espaços livres internos, o ruído ambiente de fundo, é ligeiramente inferior, com valores de $56 \mathrm{~dB}$ nos pontos 8 e 11; quanto ao ruído dos aviões, também neste caso excede os $75 \mathrm{~dB}$.

O nível de ruído de fundo é aceitável para as atividades corriqueiras realizadas nos espaços livres, sendo possível manter uma conversa normal. Atividades como o lazer recreativo ou esportivo, normalmente, geram intensidades iguais ou superiores às de fundo. Dependendo da adaptação, algumas pessoas terão dificuldades em ler ou repousar, acomodadas em um banco ou mesa na calçada. Mas sem dúvida, o grande problema acústico de Moema é estar sob a rota de aproximação do 
aeroporto. Em termos de espaços livres, a solução não está na alçada do Arquiteto, mas sim no infindável debate, em termos de Gestão Urbana, sobre quem veio primeiro, o aeroporto ou as moradias, e quem deve sair, ou talvez a solução esteja em uma nova geração de aeronaves silenciosas.

\subsubsection{Higienópolis}

O percurso foi o mesmo usado para os estudos de iluminação, com treze pontos: iniciado na praça Buenos Aires, seguiu pelas ruas Piauí, Bahia e Maranhão, chegou até a av. Angélica e terminou retornando novamente pela rua Maranhão. As medições foram feitas no dia 05 de julho de 2000, entre $10 \mathrm{~h}$ e $13 \mathrm{~h}$.

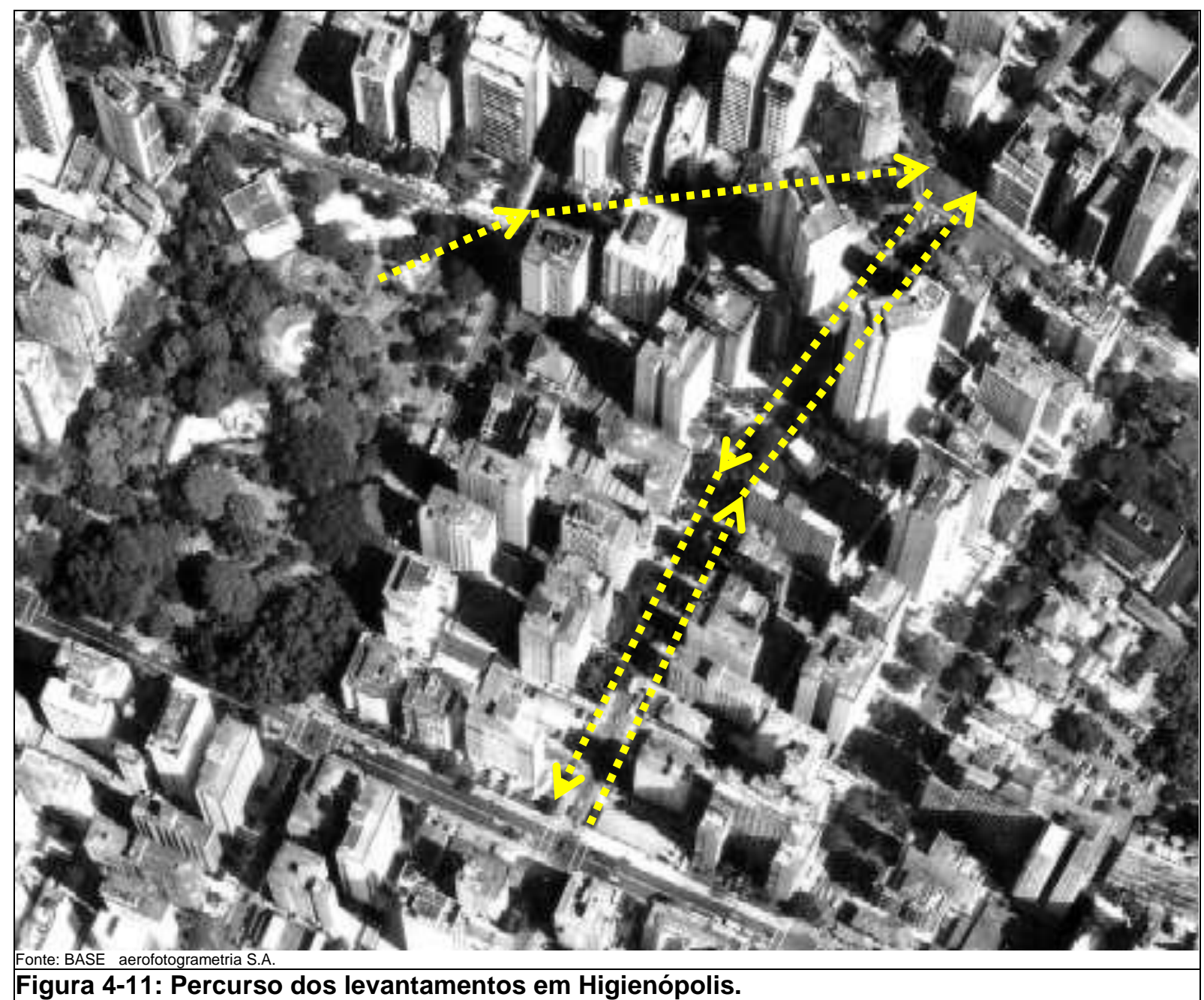

As fontes predominantes de ruídos são os automóveis e veículos de grande porte, como os ônibus que trafegam na av. Angélica, que tem mais faixas de tráfego e, conseqüentemente, é mais ruidosa. 
Os níveis sonoros obtidos, em cada ponto do percurso, medidos a uma altura de 1,50m, foram:

\begin{tabular}{|c|c|c|c|c|c|c|c|c|c|c|c|c|c|}
\hline & \begin{tabular}{|c|} 
Praça \\
B.Aires \\
\end{tabular} & \multicolumn{2}{|c|}{ r. Piauí } & \multicolumn{3}{|c|}{ r. Bahia } & \multicolumn{3}{|c|}{ r. Maranhão } & \multicolumn{2}{|c|}{ av. Angélica } & \multicolumn{2}{|c|}{ r. Maranhão } \\
\hline Ponto & 01 & 02 & 03 & 04 & 05 & 06 & 07 & 08 & 09 & 10 & 11 & 12 & 13 \\
\hline$(\mathrm{dB} A)$ & 75 & 83 & 83 a 8 & 76 a 8 & 71 as & 77 a 8 & 75 a 8 & 70 a 9 & 76 as & $68 a 10$ & \begin{tabular}{l|l|}
482 a 9 \\
\end{tabular} & 71 a 90 & 78 \\
\hline
\end{tabular}

Tabela 4-4: Níveis Sonoros obtidos no percurso em Higienópolis.

O ruído de fundo no percurso é de 70 a $75 \mathrm{~dB}$, bem mais intenso que em Moema, já que o tráfego em Higienópolis é mais denso e constante. Como o tráfego na r. Bahia e na r. Maranhão sobe o relevo, as acelerações são mais fortes e os picos ocorrem quando da abertura dos semáforos.

O ruído mais intenso $104 \mathrm{~dB}$ foi medido na esquina da av. Angélica com a $\mathrm{r}$. Maranhão, também no momento da saída dos veículos nos semáforos.

Todas as pessoas que vivem em cidades barulhentas, como São Paulo, estão expostas constantemente a algum tipo de ruído e com o tempo vão perdendo a sensibilidade auditiva.

O prejuízo é maior e irreversível se a exposição for constante e as intensidades forem superiores aos limites de $70 \mathrm{~dB}$ de dia e $60 \mathrm{~dB}$ à noite, estabelecidos pela portaria 92/80 do Ministério do Interior (citada no item 2.4.1).

Temos maior capacidade de adaptação e tolerância a ruídos brancos ${ }^{69}$ contínuos, e somos mais afetados por sons intermitentes de freqüências puras da faixa de $2400 \mathrm{a}$ $4800 \mathrm{~Hz}^{70}$. As pessoas que vivenciam o ambiente sonoro de Higienópolis estão expostas a intensidades acima das aceitáveis e, portanto, mais susceptíveis a danos auditivos.

\subsubsection{Recomendações}

Os ruídos devem ser bloqueados ou eliminados nas fontes; o ideal seria que os veículos terrestres e aéreos gerassem baixos níveis de intensidade sonora, no máximo 60dB.

69 Ruído Branco é o ruído composto por todas as freqüências do espectro sonoro, ou que somos capazes de ouvir, teoricamente de 20 a $20.000 \mathrm{~Hz}$.

70 IIDA, Itiro e WIERZZBICKI, Henri A. J. - Ergonomia, $3^{\text {a }}$ ed.,São Paulo, FEl,1978. (p.265) 
Embora os novos automóveis e aviões gerem menos ruídos que há três décadas atrás, a expansão da frota e a intensificação do uso dos veículos têm neutralizado esses aprimoramentos. Por exemplo, mesmo que um automóvel hoje gere $20 \mathrm{~dB}$ a menos de ruído que em 1970, naquela época tínhamos 1,5 milhões de veículos, hoje são mais de 5 milhões. Outro exemplo, é que São Paulo atualmente tem a segunda maior frota de helicópteros do mundo, perdendo apenas para Nova York.

Diante desse quadro, o Arquiteto e Urbanista, para amenizar o nível de ruídos nas áreas livres das edificações, deve: a) usar o próprio edifício como barreira acústica; b) projetar o edifício de maneira que não amplifique os sons; e c) agrupar as atividades de lazer ativo, que produzem barulho, nas áreas mais ruidosas.

Em termos urbanos, as condições dos veículos e das vias de circulação afetam o nível sonoro. Os veículos são mais ruidosos quando aceleram para sair da imobilidade; portanto, quanto melhor fluir o tráfego menos ruído será gerado, isso significa que valetas, buracos, lombadas, semáforos desregulados e tudo que atrapalhe o fluxo dos veículos, contribuem para aumentar a poluição sonora.

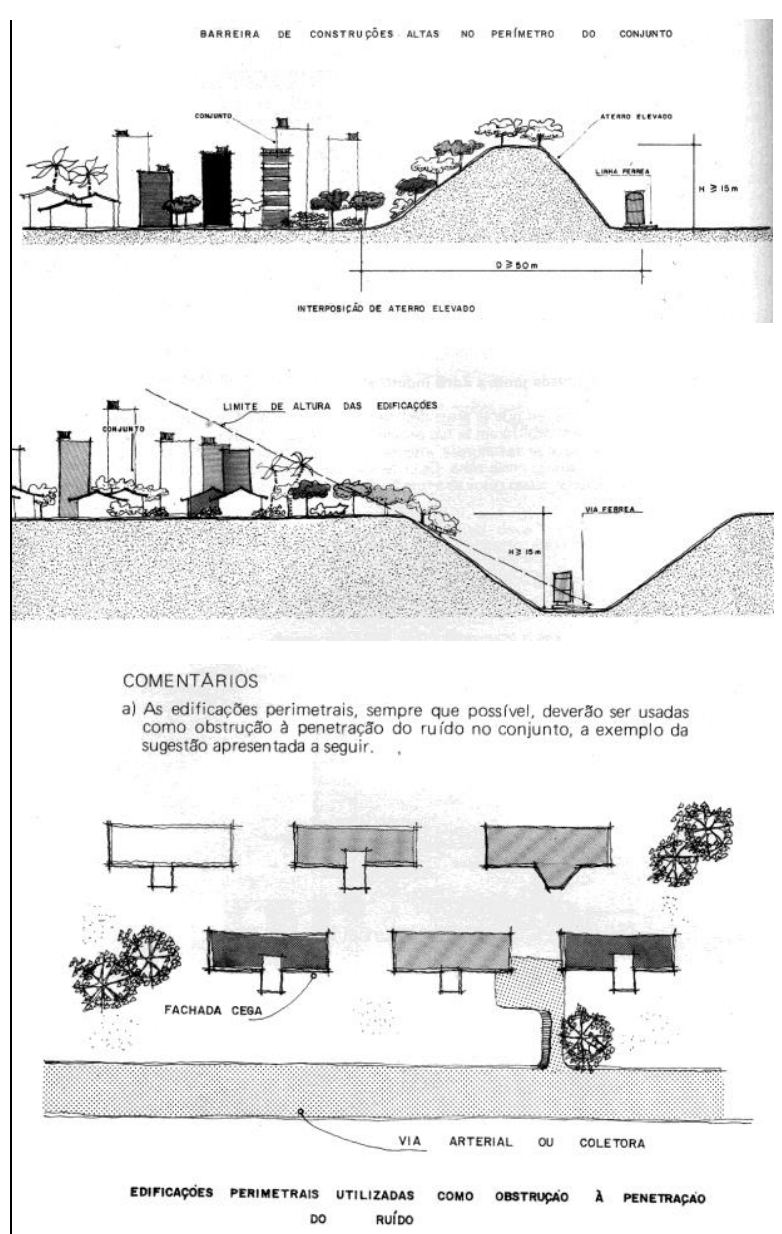

b) Evitar edificaç̃es com formas geométricas concentradoras de ruído.

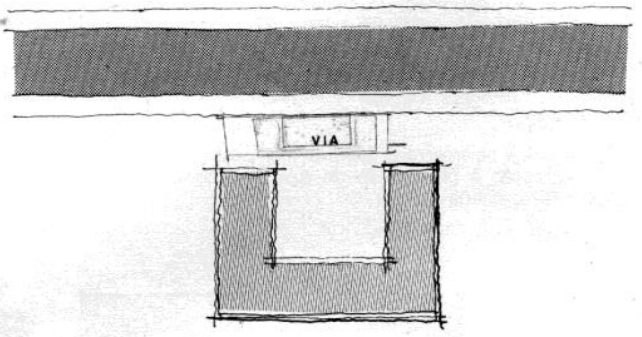

SOLUÇĀO INADEQUADA

Figura 4-12: Recomendações para adequar as construções ao ruído. (fonte: IPT1986, p64a68) 


\subsection{Cinestesia}

Os cinco sentidos mais conhecidos se caracterizam por trazer informações da realidade externa para nossa mente. Além deles, temos outros sentidos que nos informam sobre o nosso corpo, é o caso do sentido Cinestésico; através dele nossa mente percebe os movimentos musculares e a posição das articulações.

Nos aspectos arquitetônicos e urbanísticos, os problemas cinestésicos se manifestam por dificultar as atividades físicas. Com exceção das circulações para veículos, todos os outros espaços livres são para atividades físicas, por exemplo: caminhar durante o lazer contemplativo; brincar de amarelinha ao fazer o lazer recreativo; jogar uma partida de vôlei como lazer esportivo; ou subir uma rampa ao percorrer o espaço livre para circulação. Portanto, é indispensável que dimensões, inclinações, superfícies, equipamentos e os espaços como um todo, viabilizem os movimentos e deslocamentos físicos humanos. Os princípios de acessibilidade universal se aplicam a todas as pessoas e não só aos portadores de necessidades especiais ${ }^{71}$.

Nas avaliações não foram utilizados instrumentos especiais, apenas uma câmera fotográfica e nosso próprio sentido cinestésico.

A ocorrência de problemas relativos a cinestesia manifesta-se em toda a cidade, até mesmo em bairros mais planos como: Moema ou Brooklin Novo, na zona Sul e vila Luzitana, na zona Leste. Porém, são problemas mais evidentes nas áreas com maiores declividades topográficas como: Perdizes, na zona Oeste; Freguesia do Ó e Santana na zona Norte; vila Mascote, Real Parque e Jardim da Saúde, na zona Sul.

\subsubsection{Constatações de Inadequações Cinestésicas}

Os estudos examinaram áreas em bairros com grandes declividades como Freguesia do Ó e Perdizes, e também locais mais planos como a Praça da Árvore e Moema.

A maior parte dos espaços livres é dedicada à circulação de veículos e pedestres. No entanto, se compararmos as circulações públicas, para pedestres e para veículos, veremos a discrepância de critérios e cuidados no projeto e construção

\footnotetext{
71 Portador de necessidades especiais. Indivíduo que apresenta, em caráter permanente ou temporário, algum tipo de deficiência física, sensorial, cognitiva, ou múltipla, ou condutas típicas, ou altas habilidades, necessitando, por isso, de recursos especializados para desenvolver mais plenamente o seu potencial e/ou superar, ou minimizar, suas dificuldades. [No contexto escolar, costuma ser chamado portador de necessidades educativas especiais.]
} 
dessas circulações. Várias circulações para pedestres costumam ser inviáveis, pois parecem não ter sido pensadas ou houve a intenção de dificultar a circulação das pessoas.

Dimensões: Na Freguesia do Ó, as calçadas da r. João Alves são tão estreitas que uma pessoa passa apertada e, onde há postes, o transeunte tem que circular pelo leito carroçável.

Declividades: O Código de Obras e Edificações do Município de São Paulo $^{72}$ estabelece como inclinação máxima para a circulação de pedestres $10 \%$, sendo que declividades acima de $6 \%$ devem ter piso antiderrapante. Em seu item 13.1 determina: " $A$

Figura 4-13: Dimensionamento insuficiente.

acomodação

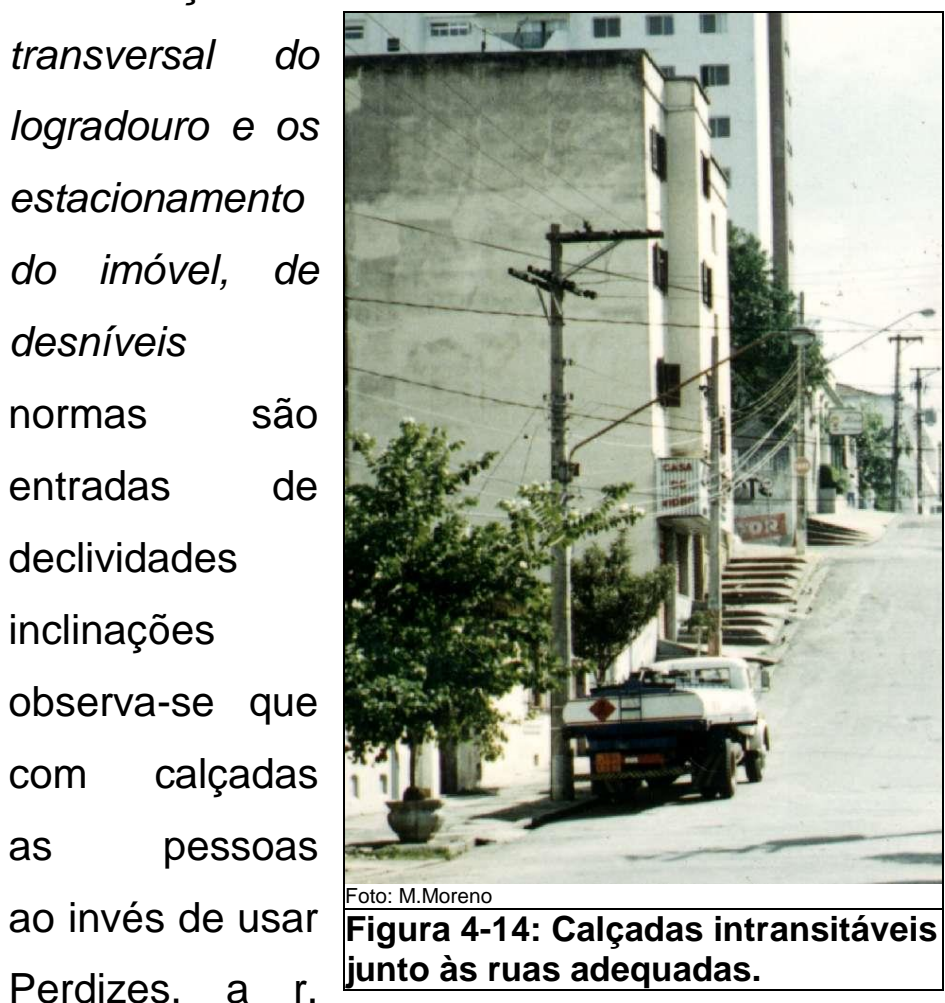

acesso entre 0 perfil do espaços de circulação e será feita exclusivamente dentro forma a não criar degraus ou abruptos na calçada". Essas desconsideradas pelas inúmeras garagens que alteram as naturais criando desníveis ou exageradas. Em muitos lugares, a rua está bem resolvida, mas intransitáveis, por isso é comum preferirem andar pelo leito da via os passeios. No bairro das Desembargador do Vale está com leito da rua correto, enquanto a calçada tem ressaltos irregulares e degraus com mais de $40 \mathrm{~cm}$.

72 Código de Obras e Edificações do Município de São Paulo, Lei no 11.228 de 25 de junho de 1992. 


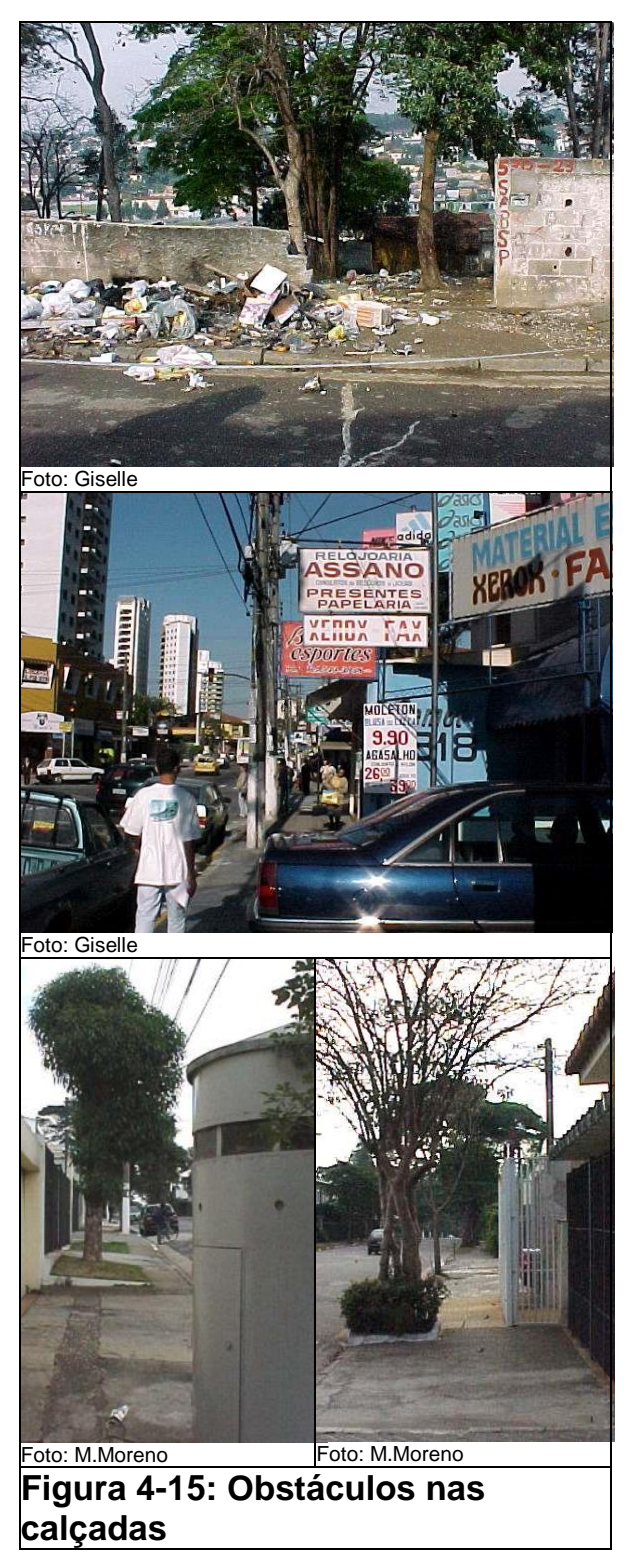

Pisos: As calçadas de Moema comprovam os problemas. Nas circulações de pedestres não há uniformidade nos pisos. São comuns revestimentos quebrados, modulação de placas incompatível com os passos das pessoas, pisos soltos, declinações laterais excessivas, ressaltos, raízes, pisos escorregadios, valetas, etc .... .

Obstáculos: A Praça da Árvore, no bairro da Saúde, ilustra esses problemas. Como nossas redes de instalações são aéreas, torna-se grande a necessidade de postes para sustentá-las. Também são obstáculos: os postinhos para telefones, caixas de correio, semáforos, placas indicativas, de propaganda e de sinalização, as lixeiras, as floreiras, os avanços de portões, as bancas de jornal, os pontos de ônibus, as bancas de ambulantes, etc... .

\subsubsection{Recomendações}

Todos esses problemas levantados são raros nos espaços livres internos ao lote e nas circulações de veículos. Para que não ocorram nas circulações externas para pedestres, é necessário que os profissionais do projeto tenham mais esmero e atribuam a mesma importância que dão para as circulações de veículos e às circulações internas.

Duas pessoas andando lado a lado necessitam de 1,20m de largura, ao cruzarem com outras duas, em sentido contrário, totalizam-se 2,40m, que deveria ser a largura mínima dos caminhos e calçadas para pedestres, à parte o espaço necessário para instalar os diversos equipamentos urbanos.

As normas, anteriormente citadas, também devem ser aplicadas aos espaços públicos. Em locais de circulação externa, com declividades maiores que $10 \%$ valem as mesmas normas do código que se aplicam para escadas internas, segundo as quais, em um degrau, o espelho ideal tem $17 \mathrm{~cm}$, chegando no máximo a $19 \mathrm{~cm}$. 


\subsection{Insolação}

Nos estudos de casos, relativos a insolação, empregamos três procedimentos, cada um deles utilizando os equipamentos correspondentes: a) Uso de maquetes e relógios de Sol, aplicados para os bairros de Perdizes e Higienópolis; b) Elaboração de maquetes eletrônicas e determinação da insolação através do software 3D Studio Max, utilizados para os bairros Freguesia do Ó, Perdizes, Higienópolis, Moema e vila Gomes Cardim; c) Uso do Espelho do Céu e sobreposição das trajetórias aparentes do Sol (projeção eqüidistante) empregando o software Auto Cad r14 e cálculo das Temperaturas Médias Radiantes (TMR) a partir de medições com o Termômetro de Bulbo Seco (TBS), Termômetro de Globo (TG) e Velocidade do ar (Var), em Moema e Higienópolis. A experimentação e a simulação física da realidade, como instrumentos de pesquisa e motivadores do processo didático, justificam a diversidade de metodologias.

Uma ressalva muito importante é que em insolação trabalhase com o Norte Geográfico (Verdadeiro), o qual é fixo. O Norte Magnético não convém para tais estudos porque não é fixo, varia com o tempo. A diferença entre os dois Nortes supera os $18^{\circ}$, o que é um erro enorme para estes estudos.

A diretriz em insolação é que devemos projetar os espaços de maneira a obter a máxima insolação no inverno e receber o mínimo de Sol no verão, porém, adotar isso como regra absoluta pode induzir a erros. É imprescindível atender as necessidades das atividades que serão desempenhadas

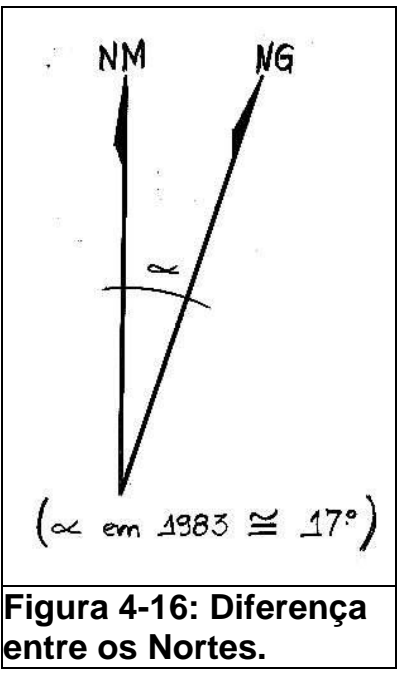
nesses espaços, por exemplo, não tem sentido obstruir a insolação no verão nas piscinas.

\subsubsection{Perdizes}

Através de fotos aéreas e cartas 1:2000 escolhemos as quatro quadras que tem os maiores desníveis topográficos. A área corresponde ao perímetro definido pelas ruas: Caiovaá, Coronel Melo Oliveira, Caraíbas e Ministro Ferreira Alves.

Com o uso de maquete das quadras e relógio de Sol, analisamos a insolação das áreas livres de dois edifícios na rua Diana, 552 e 580. 


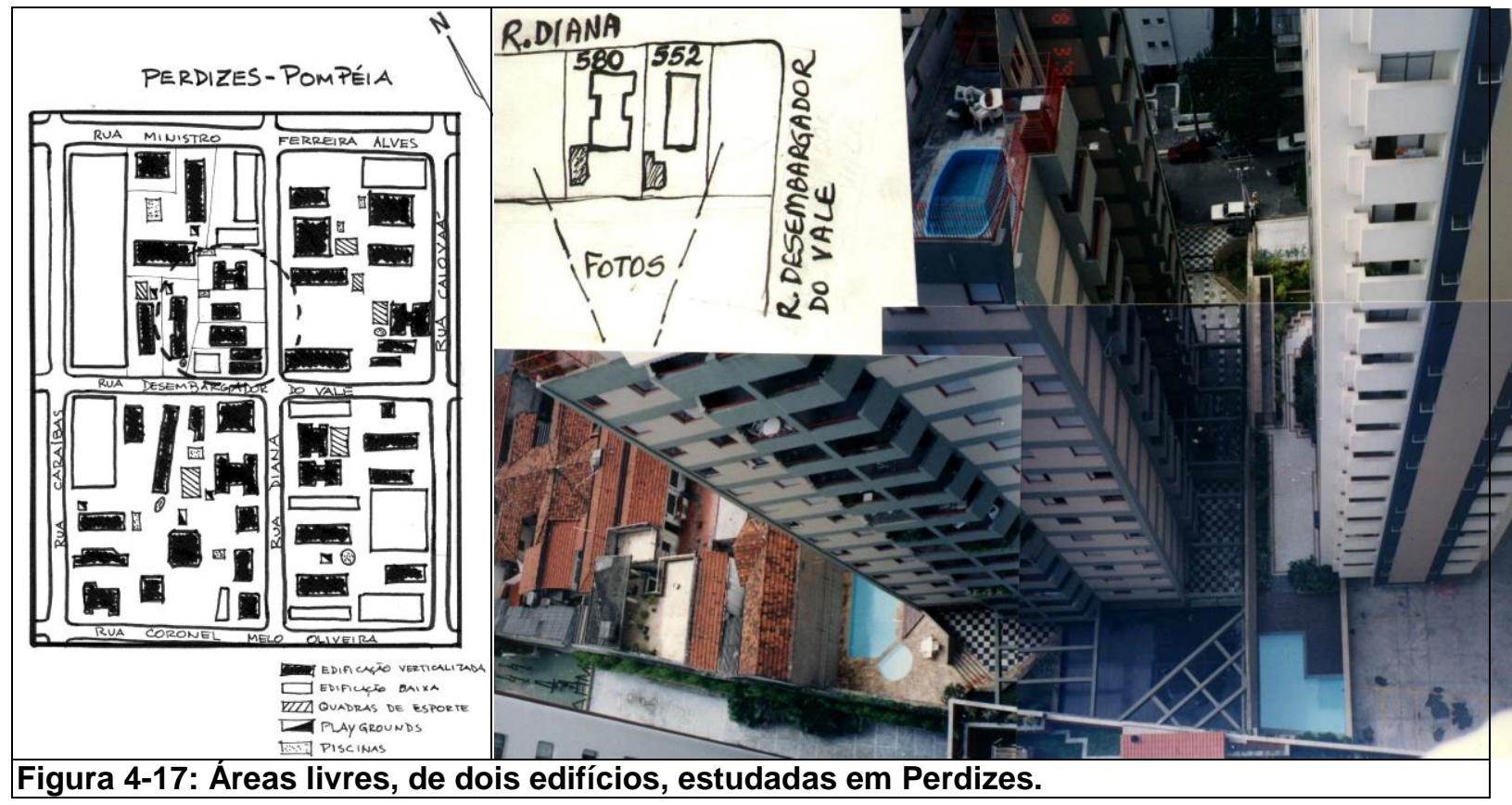

Os equipamentos disponíveis nas áreas livres destes edifícios são as piscinas, que requerem a melhor insolação possível. Conceitualmente estão bem implantadas, ambas nos vértices orientados para Norte dos respectivos lotes.

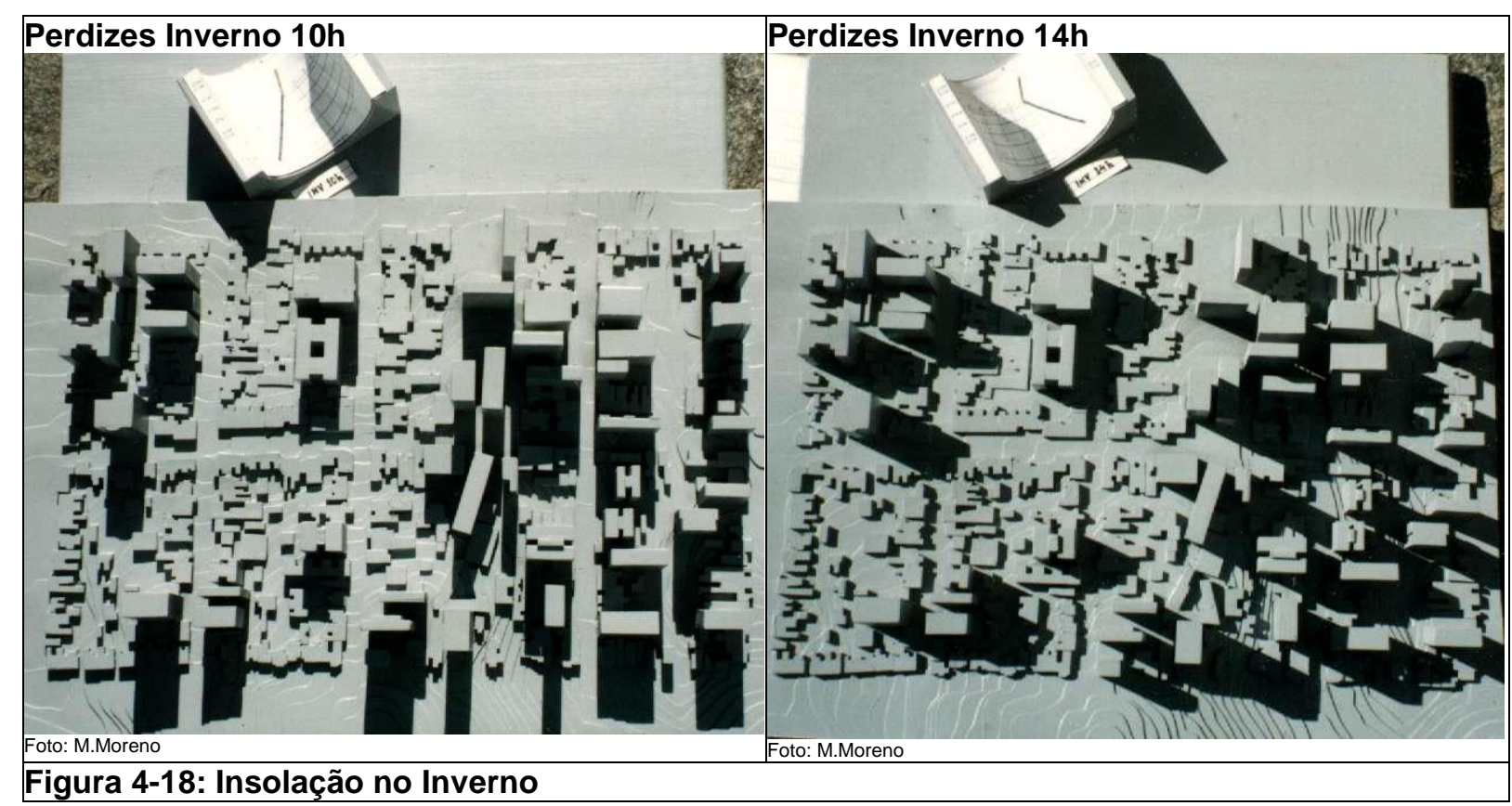

As fotos, da insolação na maquete, mostram as sombras às $10 \mathrm{~h}$ e às $14 \mathrm{~h}$, tanto no inverno como no verão, e através delas verificamos que os equipamentos ficam sombreados 0 ano todo. Dentre as várias causas que originam essas sombras nas piscinas, podemos citar: a) estão encostadas nos muros dos recuos laterais e de fundo; b) a topografia na divisa de fundo é 4 a $5 \mathrm{~m}$ mais alta; c) a proximidade dos 
edifícios vizinhos é grande porque vários deles foram construídos antes da lei do zoneamento; d) mesmo os edifícios mais recentes têm alto coeficiente de aproveitamento, porque a área é Z3-098.

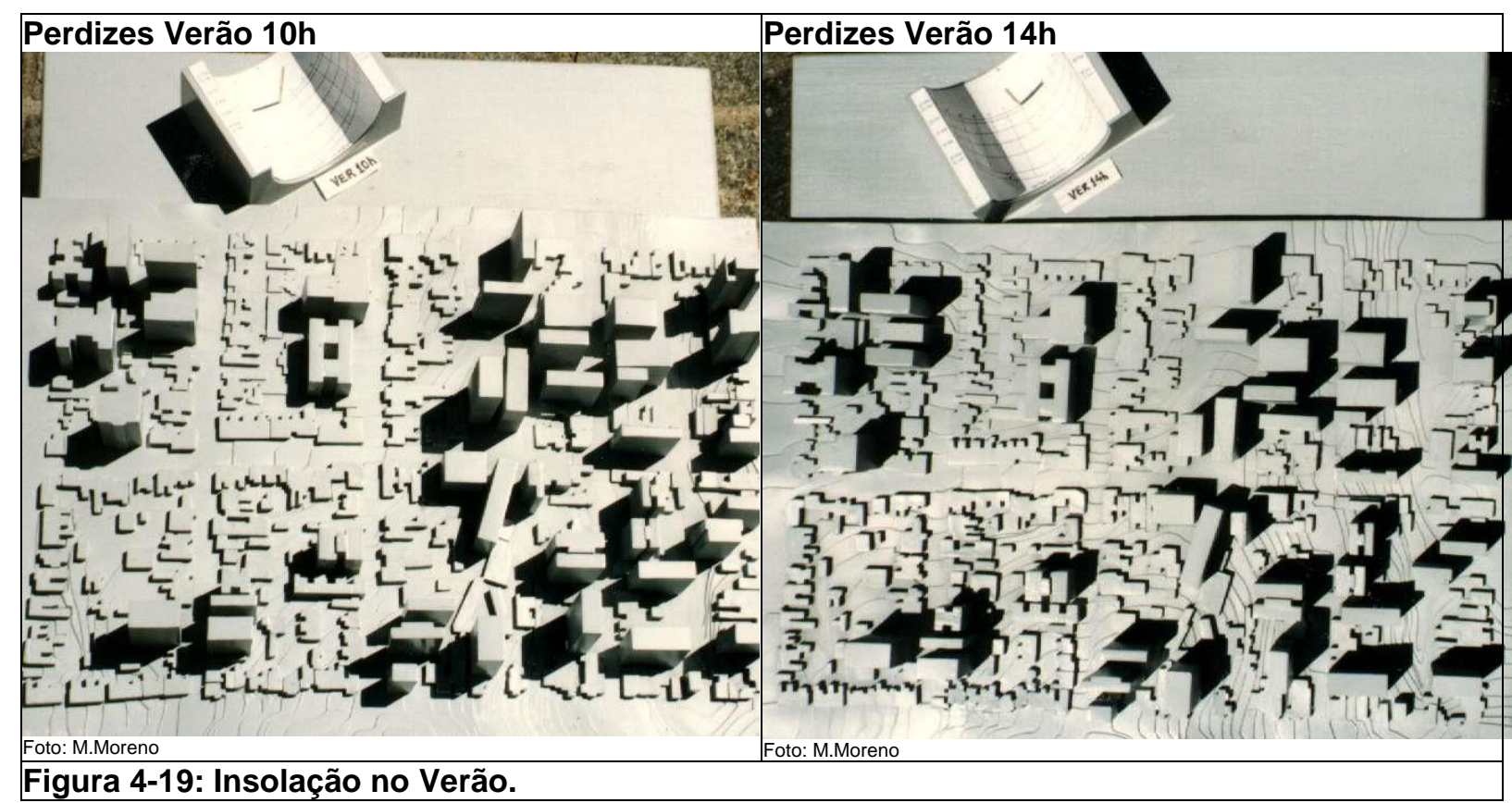

\subsubsection{Vila Gomes Cardim (Tatuapé)}

A área escolhida corresponde à quadra delimitada pelas ruas: Aguapeí, Apucarana, Monte Serrat e Professor Pedreira de Freitas. Neste caso, o desnível topográfico é suave e pouco interfere nas sombras produzidas.

A insolação foi estudada construindo-se em $3 \mathrm{D}$ a maquete eletrônica das quadras próximas com $\mathrm{o}$ software 3D Studio. Definidose os ângulos de azimute ${ }^{73} \mathrm{e}$ de altura do Sol, para cada horário pretendido, obtém-se as sombras projetadas.

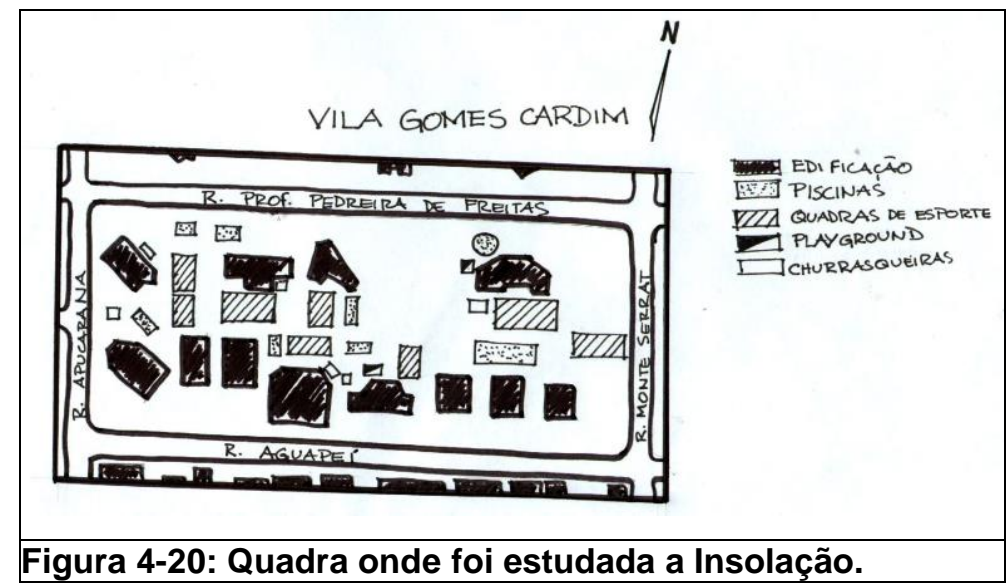

73 Azimute [Do árabe as-sumut, 'caminho', 'direção', < árabe-hispânico as-simut.] Distância angular, medida sobre o horizonte, a partir de um ponto origem, geralmente o norte, no sentido dos ponteiros do relógio. 
Examinamos as áreas livres da quadra e seus respectivos equipamentos, que são de quatro tipos: playgrounds, quadras de esportes, churrasqueiras e piscinas. Como a área é de verticalização recente e pertence à Z2, a implantação tem taxas de ocupação menores e amplos espaços livres, o que permite grande flexibilidade na orientação e implantação dos equipamentos.

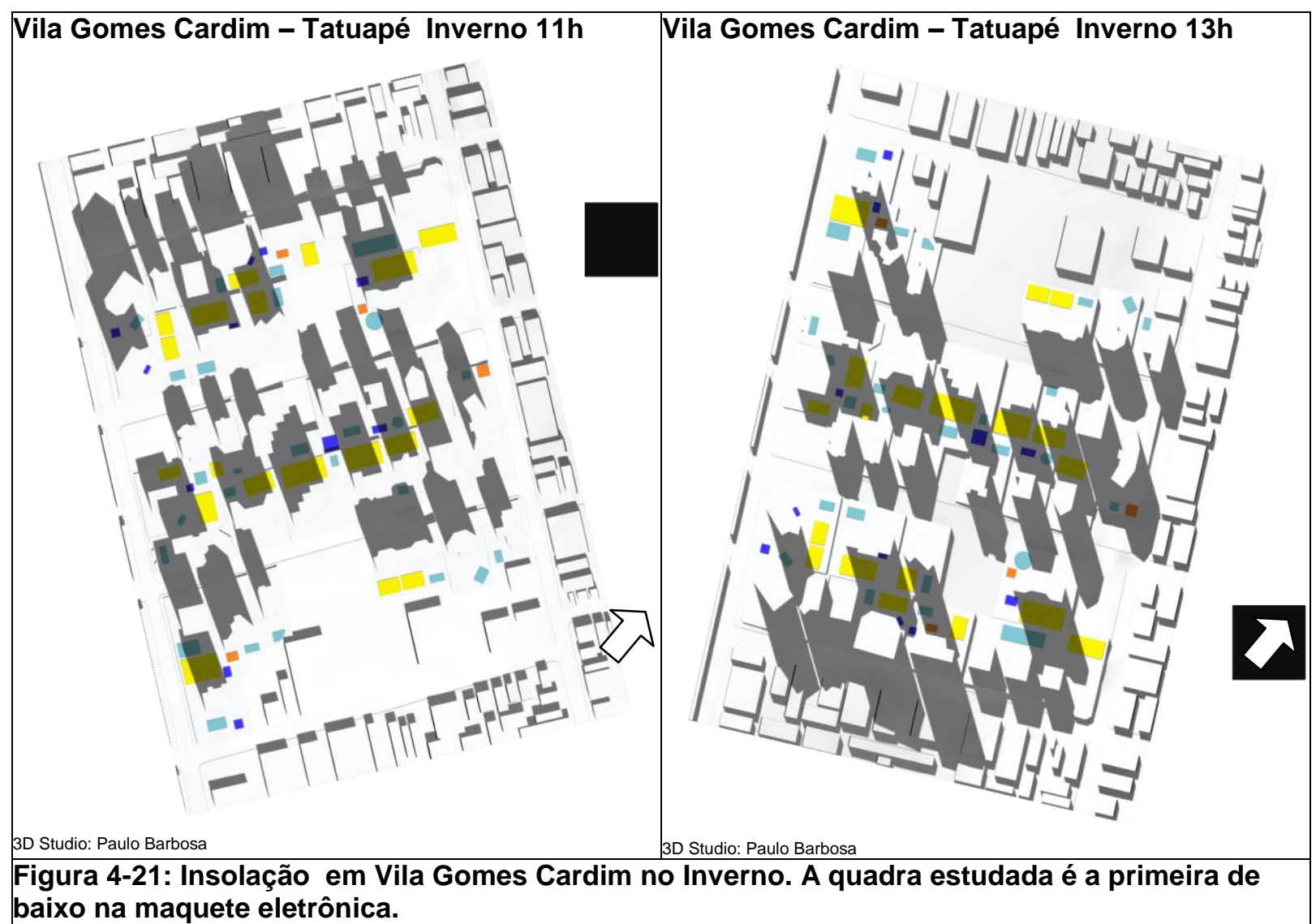

As imagens da insolação na maquete eletrônica, mostram as sombras às $11 \mathrm{~h}$ e às $13 \mathrm{~h}$, tanto no inverno como no verão; através delas verificamos que a insolação em todos os equipamentos é boa no verão, um pouco excessiva nas quadras de esportes no inverno, pois, as sombras recobrem todas as áreas livres tanto às $11 \mathrm{~h}$ como às $13 \mathrm{~h}$. 


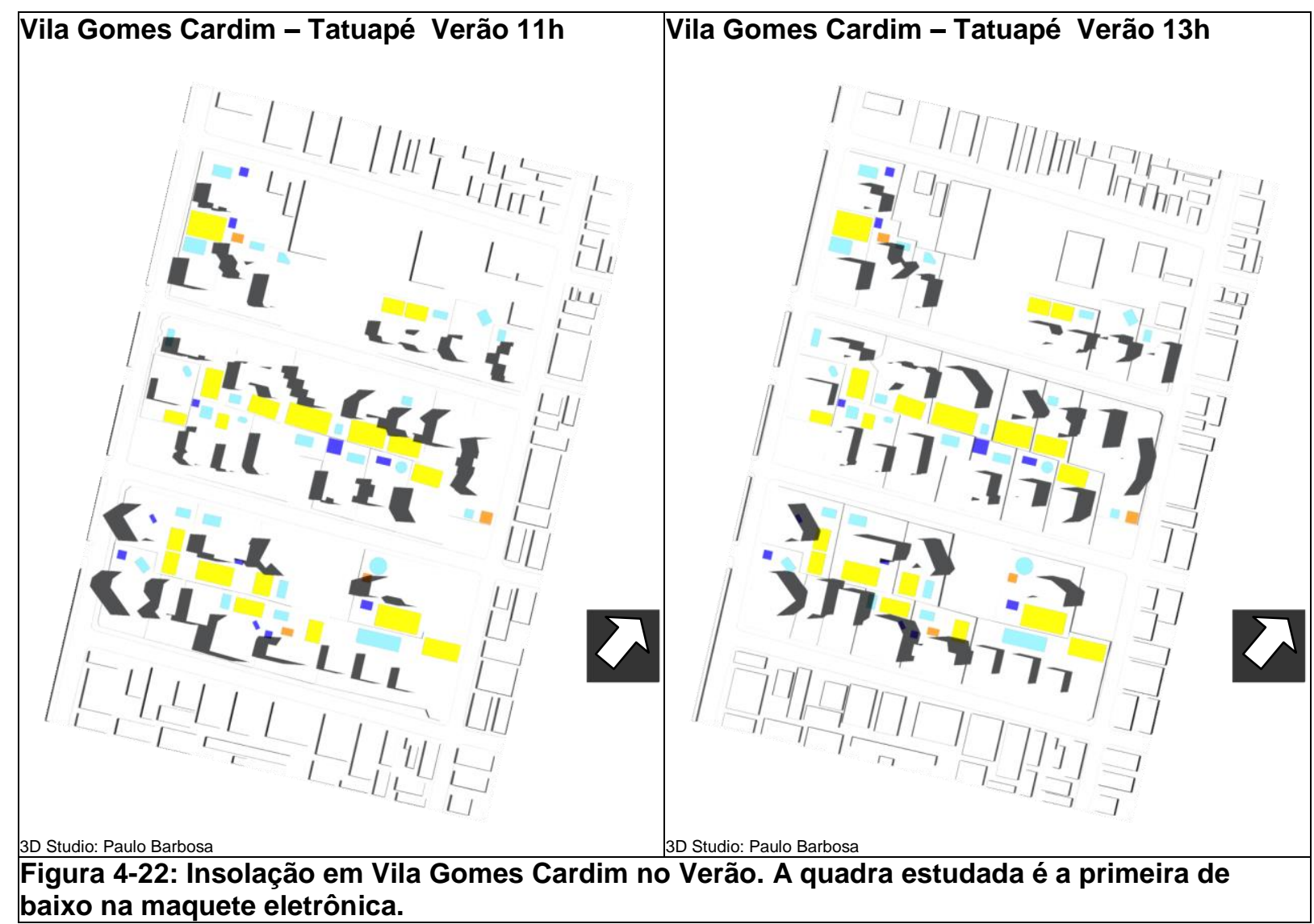

\subsubsection{Moema}

Valendo-nos do "Espelho do Céu" e do Termômetro de Globo, percorremos os mesmos onze pontos dos trajetos feitos para estudar a iluminação (ver figura 4-5), sendo cinco pontos entre a Av. Jurucê e Al. dos Maracatins e os outros seis nos espaços livres entre os edifícios situados na Av. Iraí, 297.

As temperaturas da tabela 4-5, são indispensáveis para calcular a Temperatura Radiante Média, foram obtidas em cada um dos onze pontos do percurso, com o Termômetro de $\mathrm{Globo}^{74}$, obtendo-se os seguintes valores:

\begin{tabular}{|c|c|c|c|c|c|c|c|c|c|c|c|}
\hline & \multicolumn{4}{|c|}{ Av. Jurucê e Al. dos Maracatins } & \multicolumn{4}{c|}{ Espaços livres, internos, na Av. Irai, 297} \\
\hline Ponto & 01 & 02 & 03 & 04 & 05 & 06 & 07 & 08 & 09 & 10 & 11 \\
\hline$\left({ }^{\circ} \mathrm{C}\right)$ & $\mathbf{2 8}$ & $\mathbf{2 9}$ & $\mathbf{4 0}$ & $\mathbf{3 8}$ & $\mathbf{3 8 , 5}$ & $\mathbf{3 0}$ & $\mathbf{4 0 , 5}$ & $\mathbf{4 0 , 5}$ & $\mathbf{3 5 , 5}$ & $\mathbf{3 3 , 5}$ & $\mathbf{3 7}$ \\
\hline
\end{tabular}

O método do Espelho do Céu, que implementamos para avaliar a insolação, permite obter o horário de início e término da insolação a cada dia do ano, em cada ponto

\footnotetext{
74 TG Temperatura de Globo é resultante da energia radiante absorvida por uma esfera pintada de preto fosco com $15 \mathrm{~cm}$ de diâmetro, cujo centro envolve o bulbo de um termômetro de mercúrio.
} 
estudado. A precisão do método é muito boa, desde que o Espelho do céu esteja corretamente nivelado e com sua marcação orientada para o Norte Geográfico.

Os pontos aqui apresentados são os pontos 1 e 5 do percurso nas ruas e os pontos 6 e 11 dos espaços livres entre edifícios.
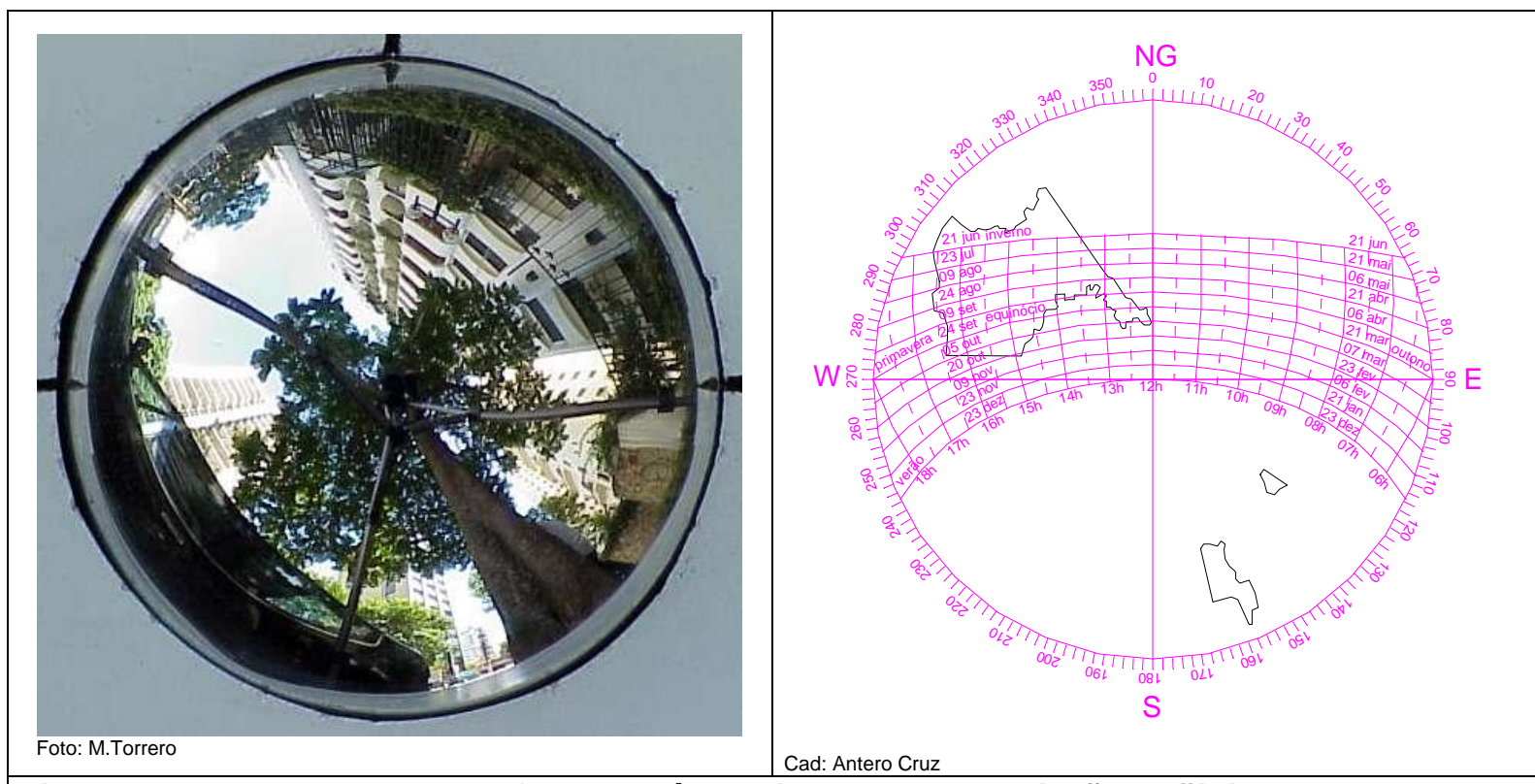

Figura 4-23: Moema ponto 1; foto do céu e diagrama em projeção eqüidistante. Dentro da área de céu visível estão os dias e horários com insolação no ponto.
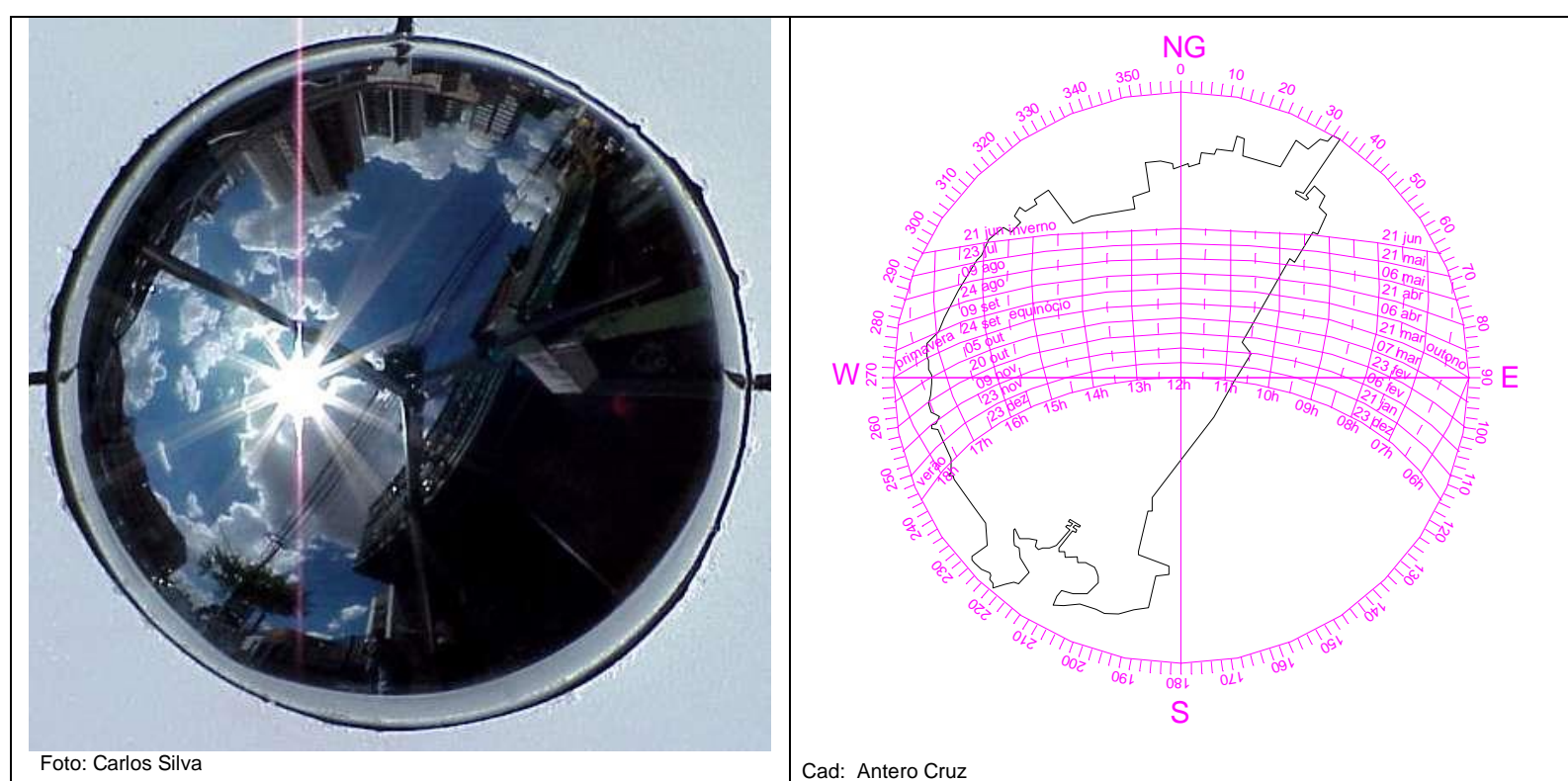

Figura 4-24: Moema ponto 5; foto do céu e diagrama em projeção eqüidistante. Dentro da área de céu visível estão os dias e horários com insolação no ponto. 

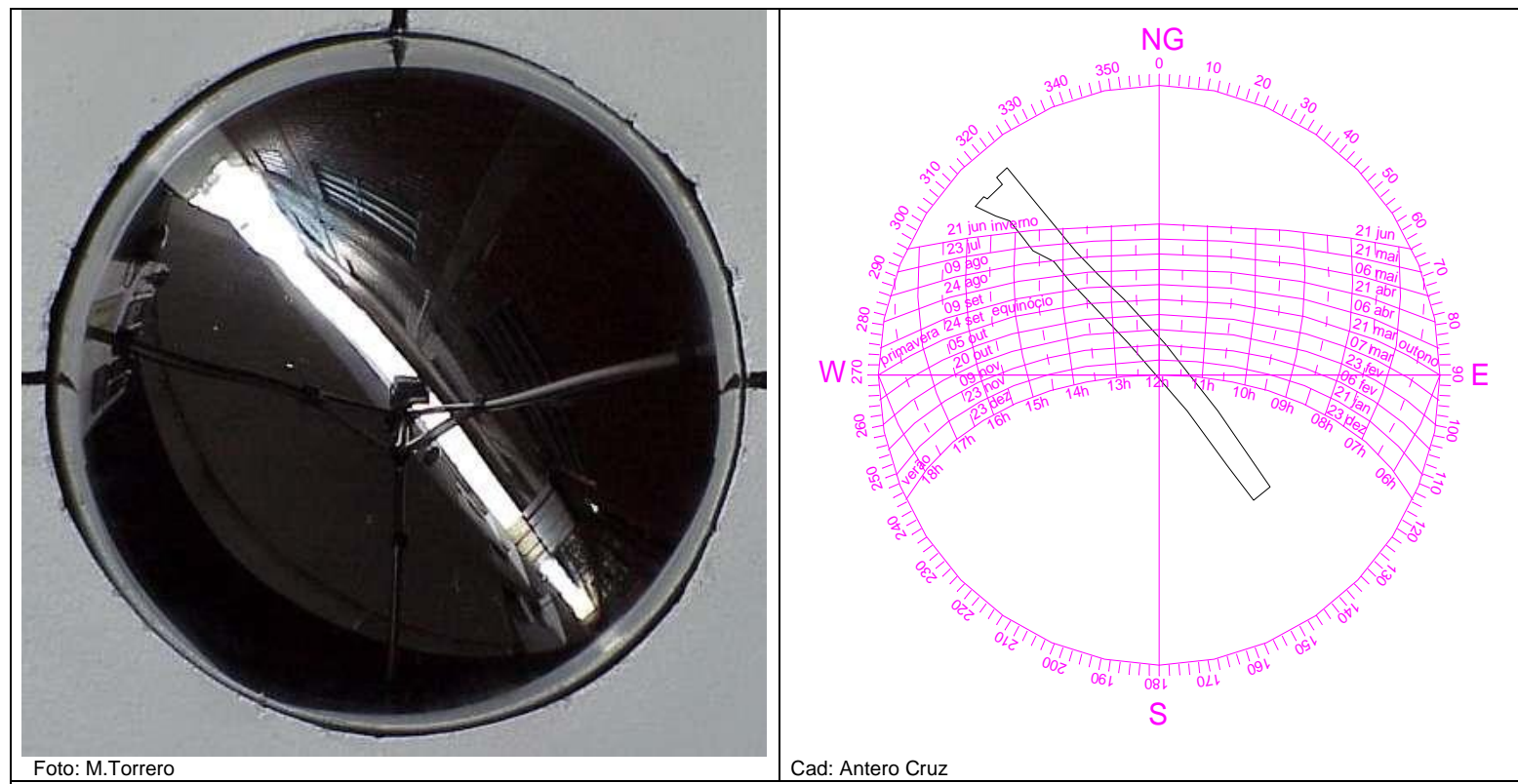

Figura 4-25: Moema ponto 6; foto do céu e diagrama em projeção eqüidistante. Dentro da área de céu visível estão os dias e horários com insolação no ponto.
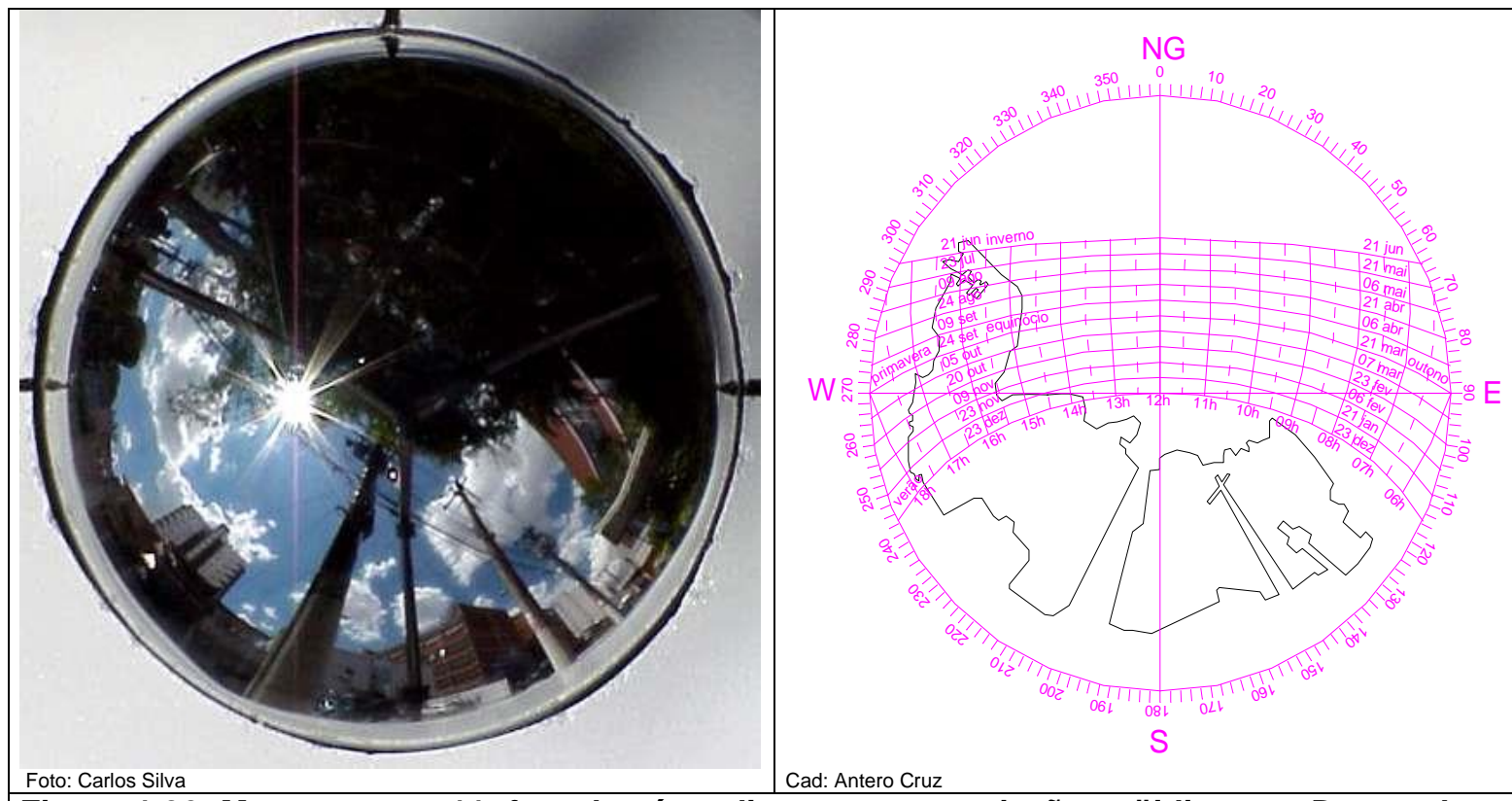

Figura 4-26: Moema ponto 11; foto do céu e diagrama em projeção eqüidistante. Dentro da área de céu visível estão os dias e horários com insolação no ponto.

\subsubsection{Higienópolis}

Fizemos fotos com o "Espelho do Céu" e medições da Temperatura de Globo (TG), também nos treze pontos percorridos em Higienópolis (ver figura 4-1). 
Os valores da TG obtidos com o Termômetro de Globo foram os seguintes:

\begin{tabular}{|c|c|c|c|c|c|c|c|c|c|c|c|c|c|}
\hline & $\begin{array}{l}\text { Praça } \\
\text { B.Aires }\end{array}$ & \multicolumn{2}{|c|}{ r. Piauí } & \multicolumn{3}{|c|}{ r. Bahia } & \multicolumn{3}{|c|}{ r. Maranhão } & \multicolumn{2}{|c|}{ av. Angélica } & \multicolumn{2}{|c|}{ r. Maranhão } \\
\hline Ponto & 01 & 02 & 03 & 04 & 05 & 06 & 07 & 08 & 09 & 10 & 11 & 12 & 13 \\
\hline$\left({ }^{\circ} \mathrm{C}\right)$ & 22 & 21 & 19 & 19 & 18 & 18,5 & 18,5 & 18,5 & 19 & 19,5 & 21,5 & 20,5 & 22 \\
\hline
\end{tabular}

Como exemplo, dentre os treze pontos realizados em Higienópolis, apresentamos os estudos feitos nos pontos 4 e 13 .
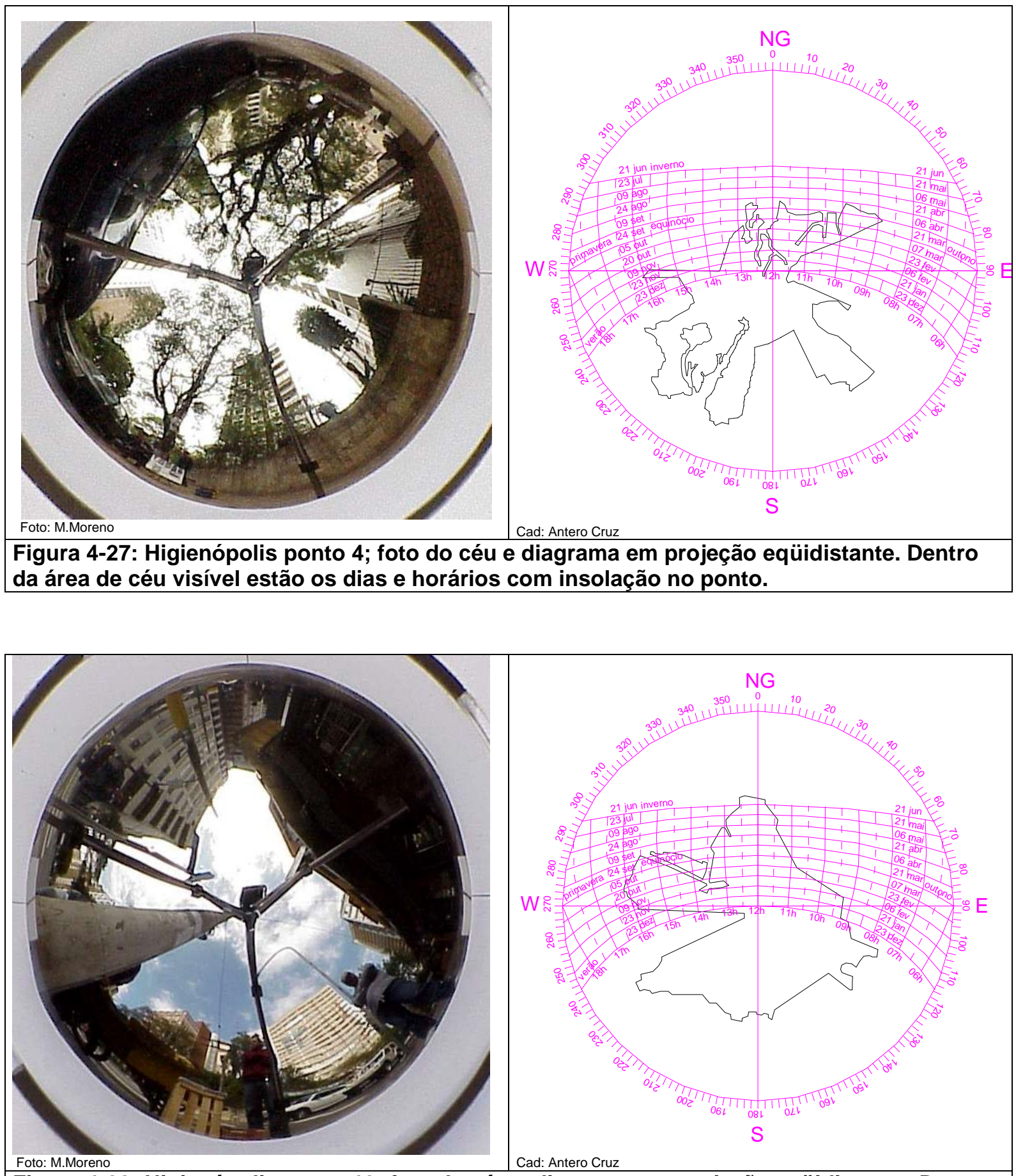

Figura 4-28: Higienópolis ponto 13; foto do céu e diagrama em projeção eqüidistante. Dentro da área de céu visível estão os dias e horários com insolação no ponto. 


\subsubsection{Recomendações}

Ver os fenômenos físicos, perceber as sombras se deslocando entre as construções, é a melhor forma de tomar decisões, tanto dos espaços livres, como os relativos à insolação dentro da edificação, por isso recomendamos que se usem maquetes volumétricas simples, até mesmo feitas em cartolina, dos edifícios que circundam a área em estudo, que junto com um relógio de Sol possam mostrar o caminhamento das sombras e visualizar várias alternativas de orientação dos elementos a serem implantados.

Os cuidados principais são: assinalar corretamente o NG e fazer as maquetes respeitando as dimensões e proporções dos elementos envolvidos, inclusive com relação aos desníveis topográficos.

A insolação recomendada nos equipamentos é: a) os playgrounds devem receber Sol todas as manhãs, do nascer do Sol até às $10 \mathrm{~h}$ ou $11 \mathrm{~h}$; b) as piscinas devem ter o máximo de insolação o ano todo; e c) as quadras de esportes não podem receber o Sol baixo (matutino e vespertino) que pode ofuscar, o conveniente é o Sol alto (entre 10h e 14h) no inverno.

\subsection{Ventos}

Os ventos têm um papel fundamental na qualidade ambiental dos espaços urbanos, porque dependendo dos posicionamentos e conformações dos edifícios podem alterar velocidades e trajetórias; por exemplo, podem formar redemoinhos que concentram gases e material particulado. Além disso, o vento é o principal meio de amenizar o calor em regiões que têm quase oito meses do ano com clima úmido, como é o caso da cidade de São Paulo.

Os estudos de casos ocorreram nos bairros de Moema e Higienópolis. Os instrumentos utilizados foram: anemômetro de ventoinha marca Lutron, modelo AM4201, termo-anemômetro marca Alnor e Túnel de Vento Atmosférico, cuja construção, calibração e testes estão detalhados no capítulo 5 .

\subsubsection{Higienópolis}

O trajeto de treze pontos foi iniciado na praça Buenos Aires; percorreu as ruas Piauí, Bahia e Maranhão; chegou até av. Angélica e voltou novamente pela rua Maranhão. 
As medições foram feitas no dia 05 de julho de 2000, entre 10h e 13h, utilizando-se o anemômetro de ventoinha, sempre colocado a uma altura de 1,50m.

Ao fazer as medições tínhamos dois objetivos: quantificar os ventos (velocidades e direções) e mapear seus fluxos nas ruas do percurso. As velocidades serviram para determinar a influência da movimentação do ar na sensação térmica, como está apresentado no item 4.7 - Microclima. O mapeamento permitiu checar algumas observações experimentais feitas no Túnel de Vento.

Estas medições têm o mérito de mostrar as possibilidades das metodologias, mesmo não tendo sido possível obter medidas simultâneas em todos os pontos e em maior número deles.

Os valores medidos foram:

\begin{tabular}{|c|c|c|c|c|c|c|c|c|c|c|c|c|c|}
\hline & $\begin{array}{c}\text { Praça } \\
\text { B.Aires }\end{array}$ & \multicolumn{2}{|c|}{ r. Piauí } & \multicolumn{3}{|c|}{ r. Bahia } & \multicolumn{3}{|c|}{ r. Maranhão } & \multicolumn{2}{|c|}{ av. Angélica } & \multicolumn{2}{|c|}{ r. Maranhão } \\
\hline Ponto & 01 & 02 & 03 & 04 & 05 & 06 & 07 & 08 & 09 & 10 & 11 & 12 & 13 \\
\hline$(\mathrm{m} / \mathrm{s})$ & 0,6 & 1,7 & 1,3 & 0,8 & 1,0 & 0,6 & 1,7 & 1,4 & 2,0 & 1,8 & 2,2 & 0,4 & 3,2 \\
\hline Direção & NE & $N W$ & $N W$ & NE & $S E$ & NE & NE & sW & $S E$ & $N E$ & $N E$ & $S E$ & $N$ \\
\hline
\end{tabular}

Os ventos, comprovadamente, sofrem alterações de velocidade e direções em função dos obstáculos. Alguns comportamentos observados nos experimentos com o Túnel foram confirmados nas medições em campo. Por exemplo, os resultados

obtidos nos pontos 9 e 12 na rua Maranhão, mostram o ar mais rápido no ponto $9 \mathrm{com} 2,0 \mathrm{~m} / \mathrm{s}$ e mais lento no ponto $12 \mathrm{com} 0,4 \mathrm{~m} / \mathrm{s}$; as imagens dos testes mostram exatamente a mesma coisa. Outra observação é que o ar corre mais rápido nos pontos mais altos do relevo, neste trajeto o ponto 13 é o mais alto; e que também corre mais rápido nos locais mais abertos que são os pontos 10 e 11 na av. Angélica.

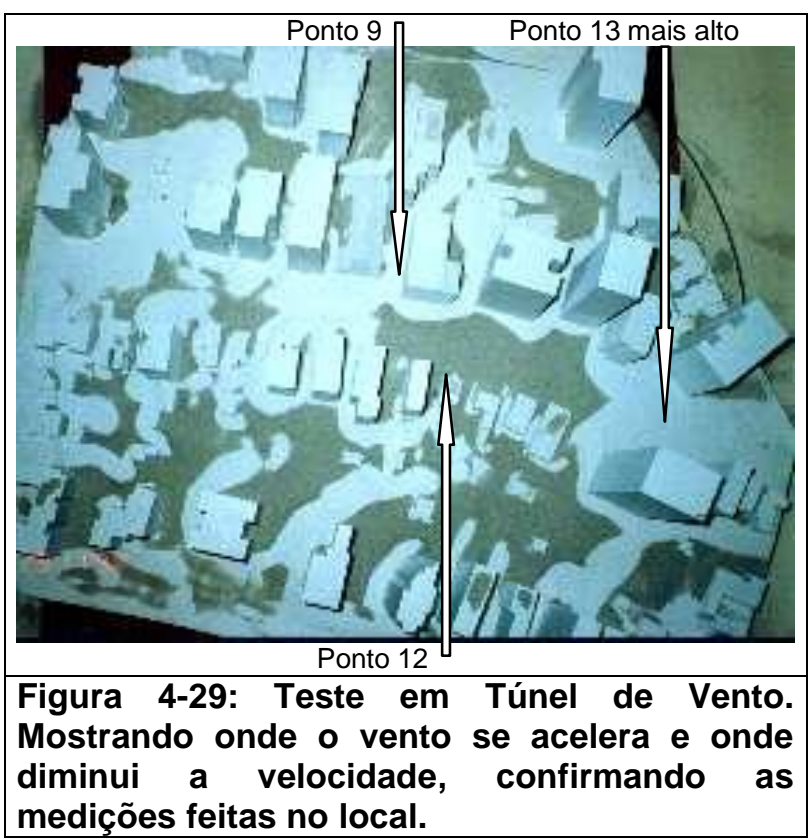




\subsubsection{Moema}

As medições foram feitas no dia 3 de janeiro de 2001, entre $11 \mathrm{~h} 30$ e $15 \mathrm{~h}$. Os onze pontos medidos estão em dois trajetos, sendo cinco pontos entre a Av. Jurucê e a Al. dos Maracatins e os outros seis pontos nos espaços livres entre os edifícios situados na Av. Iraí 297. Estas medições serviram para determinar a influência da movimentação do ar na sensação térmica, como está apresentado no item 4.7 Microclima. Os valores são os seguintes:

\begin{tabular}{|c|c|c|c|c|c|c|c|c|c|c|c|}
\hline & \multicolumn{4}{|c|}{ Av. Jurucê e Al. dos Maracatins } & \multicolumn{5}{c|}{ Espaços livres, internos, na Av. Irai, 297 } \\
\hline Ponto & 01 & 02 & 03 & 04 & 05 & 06 & 07 & 08 & 09 & 10 & 11 \\
\hline$(\mathrm{m} / \mathrm{s})$ & $\mathbf{1 , 5}$ & $\mathbf{0 , 8}$ & $\mathbf{0 , 9}$ & $\mathbf{1 , 8}$ & $\mathbf{2 , 4}$ & $\mathbf{0 , 9}$ & $\mathbf{0 , 3}$ & $\mathbf{3 , 5}$ & $\mathbf{0}$ & $\mathbf{2 , 8}$ & $\mathbf{0 , 2}$ \\
\hline Direção & $\mathbf{N W}$ & $\mathbf{N W}$ & $\mathbf{N E}$ & $\mathbf{N W}$ & $\mathbf{S W}$ & $\mathbf{N W}$ & $\mathbf{N W}$ & $\mathbf{N W}$ & - & $\mathbf{S W}$ & $\mathbf{N W}$ \\
\hline
\end{tabular}

A análise dos valores obtidos mostra que os ventos na região sopram de Oeste e são canalizados pelas ruas, fluindo das direções NW e SW. As velocidades são maiores nas ruas com menos obstáculos (veículos e árvores) e mais largas; como é o caso do ponto $5 \mathrm{com} 2,4 \mathrm{~m} / \mathrm{s}$ na Al. dos Maracatins, em comparação com o ponto 2 com $0,8 \mathrm{~m} / \mathrm{s}$ na Av. Jurucê.

Nos espaços entre edifícios, o valor mais alto, no ponto $8 \mathrm{com} 3,5 \mathrm{~m} / \mathrm{s}$, é um exemplo do efeito desfiladeiro. O ar após passar sobre construções baixas entra em um corredor estreito (2,5m de largura) delimitado por dois edifícios com 15m de altura.

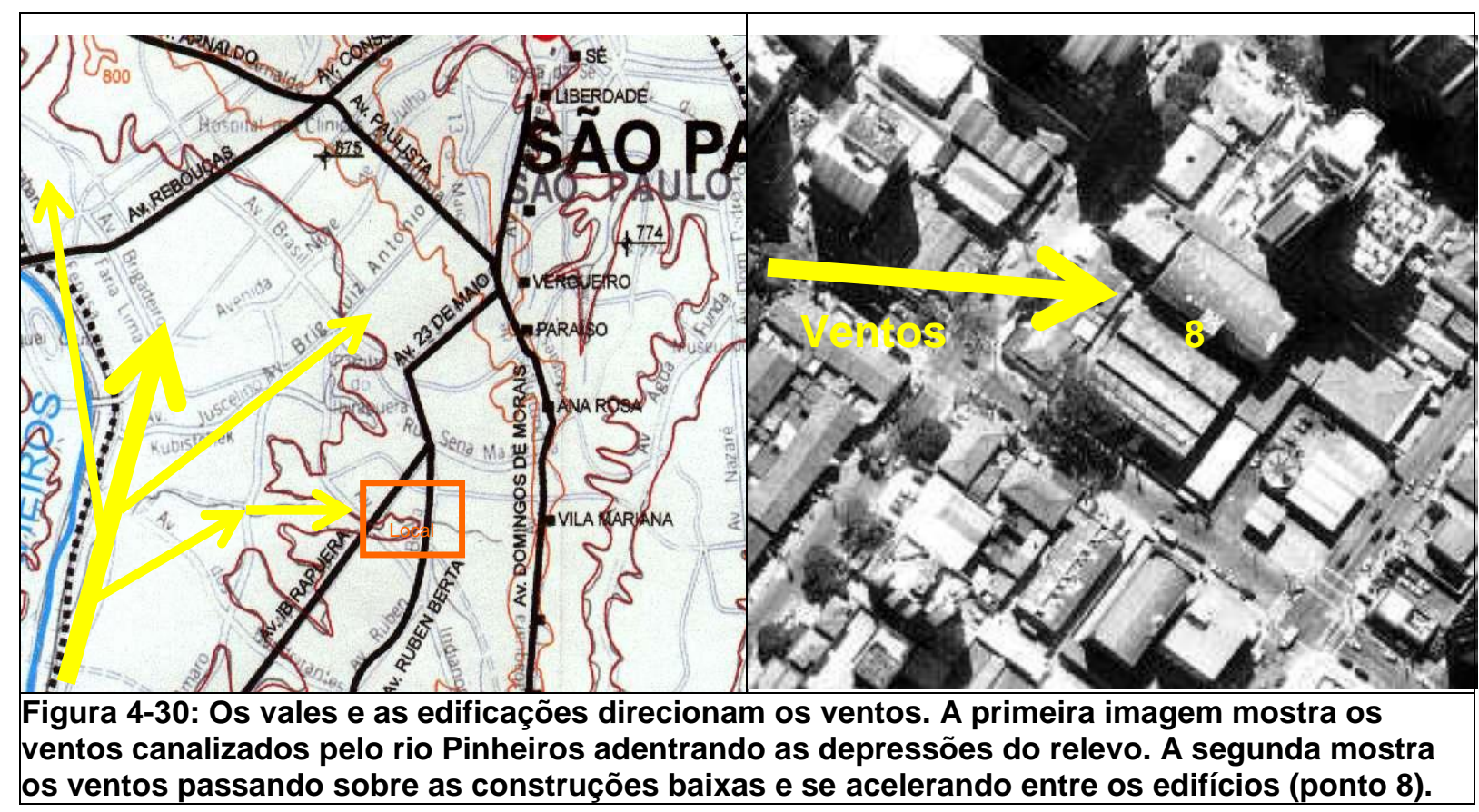




\subsubsection{Recomendações}

A ventilação tem enorme importância na higiene ambiental, pois pode deslocar ou concentrar poluentes. Também é fundamental no clima local porque tanto pode ser causa de desconforto no inverno, como reconfortante no verão ao amenizar a umidade do ar.

Recomendar que os projetos arquitetônicos e urbanísticos sejam estudados e aprimorados a partir de testes em túneis de vento ainda é utopia. O profissional pode desenvolver sensibilidade sobre o comportamento do ar ao fluir entre as edificações, a partir de experimentações com um anemômetro, fazendo medições, mapeando os ventos e analisando os resultados.

\subsection{Umidades}

A Arquitetura e o Urbanismo no âmbito local e em curto prazo, podem contribuir para aumentar a umidade do ar, reduzi-la é algo que implica em alterar a capacidade evaporativa de uma grande área e não é uma obra que vai alterá-la. Para tanto são necessárias alterações em grande escala como, por exemplo, o significativo aumento da área impermeabilizada e a mudança das características das superfícies causadas pela urbanização; esse tipo de alteração geralmente só ocorre em longo prazo.

As umidades relativas do ar foram medidas com três equipamentos: um termo higrômetro digital modelo HT-3001C marca Lutron; um psicrômetro de Augusto com os termômetros de bulbo seco e de bulbo úmido marca Incotherm, que requer o uso da carta psicrométrica; e um higrômetro de fio de cabelo marca Sunbean.

\subsubsection{Higienópolis e Moema}

As medições foram feitas nos mesmos percursos anteriores percorridos em Higienópolis e Moema. Em Higienópolis estivemos no período do inverno dia 5 de julho de 2000 e em Moema as medições foram feitas no verão dia 3 de janeiro de 2001. Os dados obtidos são utilizados para avaliar o grau de conforto que as pessoas experimentam em cada ponto do percurso. 
Os resultados, em cada bairro foram os seguintes:

\begin{tabular}{|c|c|c|c|c|c|c|c|c|c|c|c|c|c|}
\hline & \begin{tabular}{|c|} 
Praça \\
B.Aires \\
\end{tabular} & \multicolumn{2}{|c|}{ r. Piauí } & \multicolumn{3}{|c|}{ r. Bahia } & \multicolumn{3}{|c|}{ r. Maranhão } & \multicolumn{2}{|c|}{ av. Angélica } & \multicolumn{2}{|c|}{ r. Maranhão } \\
\hline Ponto & 01 & 02 & 03 & 04 & 05 & 06 & 07 & 08 & 09 & 10 & 11 & 12 & 13 \\
\hline UR(\%) & 75 & 77 & 84 & 75 & 78 & 79 & 79 & 78 & 77 & 77 & 74 & 70 & 69 \\
\hline $\operatorname{TBS}\left({ }^{\circ} \mathrm{C}\right)$ & 20 & 20,5 & 18,5 & 18,5 & 17,5 & 18 & 18 & 18,5 & 18,5 & 19 & 21 & 19,5 & 21,5 \\
\hline
\end{tabular}
Tabela 4-9: Umidades Relativas e Temperaturas do Ar obtidas no percurso em Higienópolis no Inverno.

\begin{tabular}{|c|c|c|c|c|c|c|c|c|c|c|c|}
\hline & \multicolumn{4}{|c|}{ Av. Jurucê e Al. dos Maracatins } & \multicolumn{4}{c|}{ Espaços livres, internos, na Av. Irai, 297} \\
\hline Ponto & 01 & 02 & 03 & 04 & 05 & 06 & 07 & 08 & 09 & 10 & 11 \\
\hline UR $(\%)$ & $\mathbf{6 0}$ & $\mathbf{5 8}$ & $\mathbf{6 0}$ & $\mathbf{5 0}$ & $\mathbf{4 0}$ & $\mathbf{5 8}$ & $\mathbf{4 8}$ & $\mathbf{3 6}$ & $\mathbf{4 0}$ & $\mathbf{4 2}$ & $\mathbf{4 2}$ \\
\hline $\mathrm{TBS}\left({ }^{\circ} \mathrm{C}\right)$ & $\mathbf{2 7 , 5}$ & $\mathbf{2 8}$ & $\mathbf{3 4 , 5}$ & $\mathbf{3 6}$ & $\mathbf{3 5}$ & $\mathbf{2 9 , 5}$ & $\mathbf{3 8 , 5}$ & $\mathbf{3 5}$ & $\mathbf{3 4}$ & $\mathbf{3 2}$ & $\mathbf{3 5}$ \\
\hline
\end{tabular}

Tabela 4-10: Umidades Relativas e Temperaturas do Ar obtidas nos percursos em Moema no Verão.

\subsubsection{Recomendações}

A Umidade Relativa do ar merece especial atenção do Arquiteto e Urbanista porque grande parte do ano, aproximadamente oito meses, é alta ficando acima de $70 \%$, portanto, é conveniente evitar situações que contribuam para acentuar essa umidade, como por exemplo espelhos d'água.

Por outro lado, nas últimas décadas tem se confirmado uma gradual redução da umidade do ar em São Paulo, que já não é mais a terra da garoa como era conhecida até metade do século passado. Durante 0 ano, alguns dias têm apresentado umidades relativas muito baixas, com valores aquém de $50 \%$, típicos de regiões semi-áridas.

Em vista disso, continuamos defendendo que se evitem as superfícies de água permanentes, mas recomendamos sistemas de umidificação do ar, acionáveis nas ocasiões com ar muito seco, que ao que parece tendem a ser cada vez mais freqüentes. O profissional poderia prever para estas ocasiões, meios para acionar fontes, cascatas, cortinas de água e até aspersores nas coberturas.

\subsection{Sensação Térmica e Variáveis Climáticas}

Normalmente as pessoas descrevem as alterações climáticas como variações térmicas, dizem que faz calor ou que faz frio. Na verdade, a sensação térmica é a 
impressão física provocada pelas trocas térmicas que ocorrem entre o corpo humano e o ambiente.

Não é só a variável térmica que determina a sensação de bem estar climático. Sabemos que também estão envolvidas variáveis eólicas (vento), higrométricas (umidade) e radiativas (insolação).

Vários têm sido os estudos ${ }^{75}$ para relacionar essas variáveis e estabelecer as condições de conforto. As normas ISO 7730/84 e ASHRAE 55/92, elaboradas a partir das equações desenvolvidas por Fanger $^{76}$, trazem critérios para a avaliação do conforto, levando em consideração todas as variáveis climáticas, e também, o tipo de atividade (metabolismo) que o indivíduo está realizando e sua vestimenta (clothing). As normas estabelecem que um ambiente só será considerado adequado se pelo menos $80 \%$ de seus ocupantes expressarem satisfação.

Utilizando as equações, apresentadas por essas normas, através de um software elaborado por VITTORINO, Fulvio e AKUTSU, Maria, pode-se avaliar as condições de conforto nos levantamentos realizados.

\subsubsection{Análises dos Estudos de Casos}

As medidas e unidades das variáveis envolvidas nas equações são: a) Temperatura de Bulbo Seco (TBS- $\left.{ }^{\circ} \mathrm{C}\right)$; b)Temperatura de Globo $\left(\right.$ TG- $\left.^{\circ} \mathrm{C}\right)$; c) Temperatura Radiante Média (TRM- $\left.{ }^{\circ} \mathrm{C}\right)$; d) Velocidade do $\operatorname{Ar}(\operatorname{Var}-\mathrm{m} / \mathrm{s}) ;$ e) Umidade Relativa (UR-\%); f)Metabolismo da Atividade $\left.\left(\mathbf{M}-\mathrm{W} / \mathrm{m}^{2}\right) ; \mathrm{g}\right)$ Índice de Resistência Térmica da Vestimenta (RT-clo); e h) Índice de Eficiência Mecânica (E-iem), esforço físico.

Todas as variáveis ambientais constam de nossas medições e os valores das variáveis do indivíduo são obtidos em tabelas (op.cit.76). Das tabelas de Fanger, adotamos: M: Sentado $=58 \mathrm{~W} / \mathrm{m}^{2}$; Andando $=116 \mathrm{~W} / \mathrm{m}^{2}$; Futebol $=210 \mathrm{~W} / \mathrm{m}^{2} ; \mathrm{RT}$ : Roupa Leve Verão=0,5clo; Roupa de Inverno=1,0clo; E: Atividades Normais=0 iem; Leve esforço=0,07iem.

Aplicando-se os valores nas equações, obtém-se: a) Voto Médio Estimado (VME) é um índice que varia de -3 até 3 , sendo 0 (zero) indicativo de conforto, valores negativos até -3 indicam desconforto por frio e valores positivos até +3 indicam

\footnotetext{
75 Os mais importantes são: a carta bioclimática de OLGYAY, Victor; e a carta bioclimática (construída sobre a carta psicrométrica) de GIVONI, Baruch.

76 FANGER, P.O. - Thermal confort, analysis and application in environmental engineering, New York, McGraw-Hill, 1972.
} 
desconforto por calor; b) Porcentagem de Pessoas Desconfortáveis (PPD-\%) indica a porcentagem de pessoas insatisfeitas; segundo a norma ISO 7730/84, se for menor que $20 \%$ o ambiente é considerado satisfatório quanto ao conforto térmico. Alguns autores abreviam PPD como PEI: Porcentagem Estimada de Insatisfeitos.

As análises apresentam os seguintes resultados:

\begin{tabular}{|c|c|c|c|c|c|c|c|c|c|c|c|c|c|}
\hline & \begin{tabular}{|c|} 
Praça \\
B.Aires \\
\end{tabular} & \multicolumn{2}{|c|}{ r. Piauí } & \multicolumn{3}{|c|}{ r. Bahia } & \multicolumn{3}{|c|}{ r. Maranhão } & \multicolumn{2}{|c|}{ av. Angélica } & \multicolumn{2}{|c|}{ r. Maranhão } \\
\hline Ponto & 01 & 02 & 03 & 04 & 05 & 06 & 07 & 08 & 09 & 10 & 11 & 12 & 13 \\
\hline $\operatorname{TBS}\left({ }^{\circ} \mathrm{C}\right)$ & 20 & 20,5 & 18,5 & 18,5 & 17,5 & 18 & 18 & 18,5 & 18,5 & 19 & 21 & 19,5 & 21,5 \\
\hline $\mathrm{UR}(\%)$ & 75 & 77 & 84 & 75 & 78 & 79 & 79 & 78 & 77 & 77 & 74 & 70 & 69 \\
\hline $\mathrm{TG}\left({ }^{\circ} \mathrm{C}\right)$ & 22 & 21 & 18,5 & 19 & 18 & 18,5 & 18,5 & 18,5 & 19 & 19,5 & 21,5 & 20,5 & 22 \\
\hline $\mathrm{RM}\left({ }^{\circ} \mathrm{C}\right)$ & 25,52 & 22,67 & 18,5 & 20,09 & 19,26 & 19,42 & 20,22 & 18,5 & 20,39 & 21,26 & 23,44 & 21,91 & 24,41 \\
\hline RT(clo) & 0,5 & 0,5 & 0,5 & 0,5 & 0,5 & 0,5 & 0,5 & 0,5 & 0,5 & 0,5 & 0,5 & 0,5 & 0,5 \\
\hline $\operatorname{Var}(\mathrm{m} / \mathrm{s})$ & 0,6 & 1,7 & 1,3 & 0,8 & 1,0 & 0,6 & 1,7 & 1,4 & 2,0 & 1,8 & 2,2 & 0,4 & 3,2 \\
\hline $\mathrm{M}\left(\mathrm{W} / \mathrm{m}^{2}\right)$ & 116 & 116 & 116 & 116 & 116 & 116 & 116 & 116 & 116 & 116 & 116 & 116 & 116 \\
\hline E(iem) & 0 & 0 & 0 & 0 & 0 & 0 & 0 & 0 & 0 & 0 & 0 & 0 & 0 \\
\hline VME & $-0,55$ & $-3,0$ & $-3,0$ & $-1,61$ & $-3,0$ & $-1,73$ & $-3,0$ & $-3,0$ & $-3,0$ & $-3,0$ & $-3,0$ & $-1,3$ & $-3,0$ \\
\hline PD(\%) & 11,3 & 99,1 & 99,1 & 57,1 & 99,1 & 63,2 & 99,1 & 99,1 & 99,1 & 99,1 & 99,1 & 40,1 & 99,1 \\
\hline
\end{tabular}

Tabela 4-11: Higienópolis no Inverno; cálculos do Voto Médio Estimado e da Porcentagem de Pessoas Desconfortáveis, para RT=0,5clo; $M=116 \mathrm{~W} / \mathrm{m}^{2}$ e $E=0$.

$\mathrm{Na}$ tabela 4-11, temos os cálculos de VME e PPD para os 13 pontos do percurso de Higienópolis no inverno, considerando as pessoas com: roupa leve comum $=0,5 \mathrm{clo}$; caminhando $=116 \mathrm{~W} / \mathrm{m}^{2}$ e eficiência mecânica normal $=0$ iem. Apesar das temperaturas não serem muito baixas, os ventos sempre acima de $0,5 \mathrm{~m} / \mathrm{s}$ e as roupas de verão fazem com que a sensação seja de frio. Os pontos 1 e 12 estão um pouco melhores porque têm temperaturas de $20^{\circ} \mathrm{C}$, ventos mais lentos e temperaturas radiantes um pouco maiores.

Repetindo todos os cálculos, porém, considerando roupa de inverno com $R T=1,0$ clo, obtivemos conforto em todos os pontos, como pode ser visto na tabela 4-12. Mesmo o ponto 5 ,com temperatura de $17,5^{\circ} \mathrm{C}$ e ventos de $1,0 \mathrm{~m} / \mathrm{s}$, passou a ser confortável.

\begin{tabular}{|c|c|c|c|c|c|c|c|c|c|c|c|c|c|}
\hline & $\begin{array}{c}\text { Praça } \\
\text { B.Aires }\end{array}$ & \multicolumn{2}{|c|}{ r. Piauí } & \multicolumn{3}{|c|}{ r. Bahia } & \multicolumn{3}{c|}{ r. Maranhão } & \multicolumn{2}{c|}{ av. Angélica } & \multicolumn{2}{c|}{ r. Maranhão } \\
\hline Ponto & 01 & 02 & 03 & 04 & 05 & 06 & 07 & 08 & 09 & 10 & 11 & 12 & 13 \\
\hline VME & $\mathbf{1 , 0 7}$ & $\mathbf{0 , 4 6}$ & $\mathbf{0 , 0 6}$ & $\mathbf{0 , 6 2}$ & $-\mathbf{- 0 , 0 6}$ & $\mathbf{0 , 5 8}$ & $\mathbf{0 , 1 2}$ & $\mathbf{0 , 0 4}$ & $\mathbf{- 0 , 0 5}$ & $\mathbf{0 , 2 8}$ & $\mathbf{0 , 5 0}$ & $\mathbf{0 , 7 5}$ & $\mathbf{0 , 4 3}$ \\
\hline PPD(\%) & $\mathbf{3 0 , 3}$ & $\mathbf{9 , 4}$ & $\mathbf{5 , 1}$ & $\mathbf{1 3 , 2}$ & $\mathbf{5 , 1}$ & $\mathbf{1 2 , 1}$ & $\mathbf{5 , 3}$ & $\mathbf{5 , 0}$ & $\mathbf{5 , 1}$ & $\mathbf{6 , 7}$ & $\mathbf{1 0 , 2}$ & $\mathbf{1 6 , 9}$ & $\mathbf{8 , 9}$ \\
\hline
\end{tabular}

Tabela 4-12: Higienópolis no Inverno; cálculos do Voto Médio Estimado e da Porcentagem de Pessoas Desconfortáveis, para $\mathrm{RT}=1,0 \mathrm{clo} ; \mathrm{M}=116 \mathrm{~W} / \mathrm{m}^{2}$ e $\mathrm{E}=0$. 


\begin{tabular}{|c|c|c|c|c|c|c|c|c|c|c|c|}
\hline & \multicolumn{4}{|c|}{ Av. Jurucê e Al. dos Maracatins } & \multicolumn{4}{c|}{ Espaços livres, internos, na Av. Irai, 297} \\
\hline Ponto & 01 & 02 & 03 & 04 & 05 & 06 & 07 & 08 & 09 & 10 & 11 \\
\hline TBS $\left({ }^{\circ} \mathrm{C}\right)$ & $\mathbf{2 7 , 5}$ & $\mathbf{2 8}$ & $\mathbf{3 4 , 5}$ & $\mathbf{3 6}$ & $\mathbf{3 5}$ & $\mathbf{2 9 , 5}$ & $\mathbf{3 8 , 5}$ & $\mathbf{3 5}$ & $\mathbf{3 4}$ & $\mathbf{3 2}$ & $\mathbf{3 5}$ \\
\hline $\mathrm{UR}(\%)$ & $\mathbf{6 0}$ & $\mathbf{5 8}$ & $\mathbf{6 0}$ & $\mathbf{5 0}$ & $\mathbf{4 0}$ & $\mathbf{5 8}$ & $\mathbf{4 8}$ & $\mathbf{3 6}$ & $\mathbf{4 0}$ & $\mathbf{4 2}$ & $\mathbf{4 2}$ \\
\hline $\mathrm{TG}\left({ }^{\circ} \mathrm{C}\right)$ & $\mathbf{2 8}$ & $\mathbf{2 9}$ & $\mathbf{4 0}$ & $\mathbf{3 8}$ & $\mathbf{3 8 , 5}$ & $\mathbf{3 0}$ & $\mathbf{4 0 , 5}$ & $\mathbf{4 0 , 5}$ & $\mathbf{3 5 , 5}$ & $\mathbf{3 3 , 5}$ & $\mathbf{3 7}$ \\
\hline $\mathrm{TRM}\left({ }^{\circ} \mathrm{C}\right)$ & $\mathbf{2 9 , 4 5}$ & $\mathbf{3 0 , 9 6}$ & $\mathbf{5 0 , 0 3}$ & $\mathbf{4 3 , 7 5}$ & $\mathbf{5 0 , 0 7}$ & $\mathbf{3 1 , 0 4}$ & $\mathbf{4 2 , 4 5}$ & $\mathbf{6 1 , 8 7}$ & $\mathbf{3 5 , 5 0}$ & $\mathbf{3 9 , 3 6}$ & $\mathbf{3 8 , 5 8}$ \\
\hline $\mathrm{RT}(\mathrm{clo})$ & 0,5 & 0,5 & 0,5 & 0,5 & 0,5 & 0,5 & 0,5 & 0,5 & 0,5 & 0,5 & 0,5 \\
\hline $\mathrm{Var}(\mathrm{m} / \mathrm{s})$ & $\mathbf{1 , 5}$ & $\mathbf{0 , 8}$ & $\mathbf{0 , 9}$ & $\mathbf{1 , 8}$ & $\mathbf{2 , 4}$ & $\mathbf{0 , 9}$ & $\mathbf{0 , 3}$ & $\mathbf{3 , 5}$ & $\mathbf{0}$ & $\mathbf{2 , 8}$ & $\mathbf{0 , 2}$ \\
\hline $\mathrm{M}\left(\mathrm{W} / \mathrm{m}^{2}\right)$ & 116 & 116 & 116 & 116 & 116 & 116 & 116 & 116 & 116 & 116 & 116 \\
\hline E(iem) & 0 & 0 & 0 & 0 & 0 & 0 & 0 & 0 & 0 & 0 & 0 \\
\hline VME & $\mathbf{1 , 2 0}$ & $\mathbf{1 , 8 8}$ & $\mathbf{3 , 0 0}$ & $\mathbf{3 , 0 0}$ & $\mathbf{3 , 0 0}$ & $\mathbf{2 , 0 7}$ & $\mathbf{3 , 0 0}$ & $\mathbf{3 , 0 0}$ & $\mathbf{2 , 7 7}$ & $\mathbf{2 , 6 7}$ & $\mathbf{3 , 0 0}$ \\
\hline PPD(\%) & $\mathbf{3 5 , 4}$ & $\mathbf{7 0 , 8}$ & $\mathbf{9 9 , 1}$ & $\mathbf{9 9 , 1}$ & $\mathbf{9 9 , 1}$ & $\mathbf{8 0 , 0 0}$ & $\mathbf{9 9 , 1}$ & $\mathbf{9 9 , 1}$ & $\mathbf{9 7 , 5}$ & $\mathbf{9 6 , 4}$ & $\mathbf{9 9 , 1}$ \\
\hline
\end{tabular}

Tabela 4-13: Moema no Verão; cálculos do Voto Médio Estimado e da Porcentagem de Pessoas Desconfortáveis, para $R T=0,5 c l o ; M=116 \mathrm{~W} / \mathrm{m}^{2}$ e $E=0$.

Na tabela 4-13, temos os cálculos de VME e PPD para os 11 pontos dos percursos de Moema no verão, considerando as pessoas com: roupa leve comum =0,5clo; caminhando $=116 \mathrm{~W} / \mathrm{m}^{2}$ e eficiência mecânica normal $=0$ iem. A temperatura menos quente ocorreu no ponto 1 , no qual obtivemos o melhor resultado. A Temperatura Radiante Média (TRM) foi praticamente igual à TBS, o que significa que a área está sombreada, e que as sombras, principalmente de árvores ${ }^{77}$, podem contribuir muito para amenizar a sensação térmica. Outra observação importante é o efeito resfriador dos ventos, no ponto 1 onde os ventos estavam a $1,5 \mathrm{~m} / \mathrm{s}$ o número estimado de pessoas satisfeitas foi muito maior que no ponto 2 onde o vento corria a $0,8 \mathrm{~m} / \mathrm{s}$.

Para os outros pontos refizemos os cálculos considerando sombreamento, adotando TRM=TBS, conforme tabela 4-14.

\begin{tabular}{|c|c|c|c|c|c|c|c|c|c|c|c|}
\hline & \multicolumn{4}{|c}{ Av. Jurucê e Al. dos Maracatins } & \multicolumn{5}{c|}{ Espaços livres, internos, na Av. Irai, 297} \\
\hline Ponto & 01 & 02 & 03 & 04 & 05 & 06 & 07 & 08 & 09 & 10 & 11 \\
\hline TBS $\left({ }^{\circ} \mathrm{C}\right)$ & $\mathbf{2 7 , 5}$ & $\mathbf{2 8}$ & $\mathbf{3 4 , 5}$ & $\mathbf{3 6}$ & $\mathbf{3 5}$ & $\mathbf{2 9 , 5}$ & $\mathbf{3 8 , 5}$ & $\mathbf{3 5}$ & $\mathbf{3 4}$ & $\mathbf{3 2}$ & $\mathbf{3 5}$ \\
\hline $\mathrm{UR}(\%)$ & $\mathbf{6 0}$ & $\mathbf{5 8}$ & $\mathbf{6 0}$ & $\mathbf{5 0}$ & $\mathbf{4 0}$ & $\mathbf{5 8}$ & $\mathbf{4 8}$ & $\mathbf{3 6}$ & $\mathbf{4 0}$ & $\mathbf{4 2}$ & $\mathbf{4 2}$ \\
\hline $\mathrm{TRM}\left({ }^{\circ} \mathrm{C}\right)$ & $\mathbf{2 7 , 5}$ & $\mathbf{2 8}$ & $\mathbf{3 4 . 5}$ & $\mathbf{3 6}$ & $\mathbf{3 5}$ & $\mathbf{2 9 , 5}$ & $\mathbf{3 8 , 5}$ & $\mathbf{3 5}$ & $\mathbf{3 4}$ & $\mathbf{3 2}$ & $\mathbf{3 5}$ \\
\hline $\mathrm{RT}(\mathrm{clo})$ & 0,5 & 0,5 & 0,5 & 0,5 & 0,5 & 0,5 & 0,5 & 0,5 & 0,5 & 0,5 & 0,5 \\
\hline $\operatorname{Var}(\mathrm{m} / \mathrm{s})$ & $\mathbf{1 , 5}$ & $\mathbf{0 , 8}$ & $\mathbf{0 , 9}$ & $\mathbf{1 , 8}$ & $\mathbf{2 , 4}$ & $\mathbf{0 , 9}$ & $\mathbf{0 , 3}$ & $\mathbf{3 , 5}$ & $\mathbf{0}$ & $\mathbf{2 , 8}$ & $\mathbf{0 , 2}$ \\
\hline $\mathrm{M}\left(\mathrm{W} / \mathrm{m}^{2}\right)$ & 116 & 116 & 116 & 116 & 116 & 116 & 116 & 116 & 116 & 116 & 116 \\
\hline E(iem) & 0 & 0 & 0 & 0 & 0 & 0 & 0 & 0 & 0 & 0 & 0 \\
\hline VME & $\mathbf{1 , 0 8}$ & $\mathbf{1 , 7 0}$ & $\mathbf{2 , 8 4}$ & $\mathbf{3 , 0 0}$ & $\mathbf{3 , 0 0}$ & $\mathbf{1 , 8 9}$ & $\mathbf{3 , 0 0}$ & $\mathbf{2 , 8 6}$ & $\mathbf{2 , 6 7}$ & $\mathbf{2 , 2 7}$ & $\mathbf{2 , 8 6}$ \\
\hline PPD(\%) & $\mathbf{2 9 , 4}$ & $\mathbf{6 1 , 5 0}$ & $\mathbf{9 8 , 2 0}$ & $\mathbf{9 9 , 1 0}$ & $\mathbf{9 9 , 1 0}$ & $\mathbf{7 1 , 6 0}$ & $\mathbf{9 9 , 1 0}$ & $\mathbf{9 8 , 3 0}$ & $\mathbf{9 6 , 3 0}$ & $\mathbf{8 7 , 3 0}$ & $\mathbf{9 8 , 3 0}$ \\
\hline
\end{tabular}

Tabela 4-14: Moema no Verão; cálculos do Voto Médio Estimado e da Porcentagem de Pessoas Desconfortáveis, para RT=0,5clo; $M=116 \mathrm{~W} / \mathrm{m}^{2}$ e E=0; porém, sombreando ( usando TRM=TBS).

\footnotetext{
77 As árvores re-irradiam muito menos calor do que os materiais das coberturas comuns, como: lajes, cimento amianto, chapas metálicas, telhas de cerâmica ou cimento, plásticos, etc... .
} 
Como pode ser observado na tabela 4-14, adotar TRM=TBS (sombreamento) não trouxe resultados significativos para temperaturas acima de $35^{\circ} \mathrm{C}$, apenas nos pontos 9 e 11 , com $34^{\circ} \mathrm{C}$ e $35^{\circ} \mathrm{C}$ respectivamente, ocorreu uma pequena melhora, convém observar que em ambos $\mathrm{o}$ ar está praticamente parado, o que significa que o vento com ar quente só piora o desconforto, ou seja, é melhor que fique parado para não transferir calor por convecção.

Com o sombreamento estamos reduzindo as trocas por radiação, com ar quente parado diminui-se o calor por convecção e as trocas por condução, de uma pessoa andando, são mínimas.

Acreditamos que em situações de umidade relativa baixa, como nestes exemplos, seria conveniente avaliar o resfriamento por evaporação. Além de controlar a convecção, a condução e a radiação, convém saber quanto calor pode ser trocado por evaporação, por exemplo borrifando vapor d'água no ar.

As formulações de Fanger consideram o efeito relativo à evaporação do suor em função da umidade relativa; não consta que o esfriamento causado por aspersão externa à pessoa entre nas ponderações.

Neste capítulo fizemos análises, lançamos mão de uma série de procedimentos e equipamentos, alguns comuns e facilmente adquiridos, outros foram desenvolvidos à medida que as questões pesquisadas necessitavam ser respondidas.

No capítulo 5 descrevemos cada equipamento e procedimentos adotados. As imagens a seguir mostram alguns dos equipamentos utilizados nas análises. 

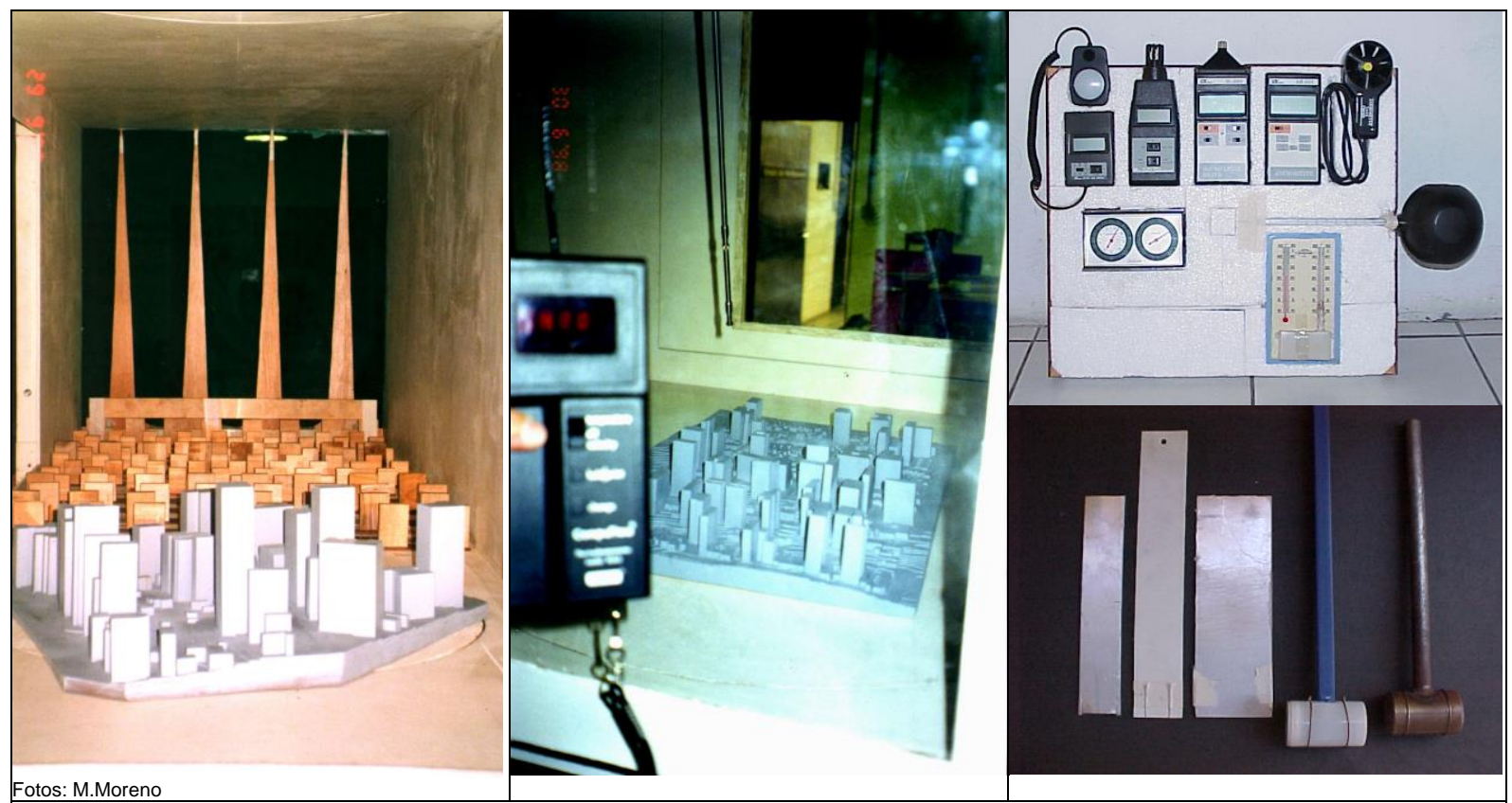

Fotos: M.Moreno
Figura 4-31: Túnel de Vento Atmosférico; Termo-anemômetro; Conjunto de Instrumentos para medição em Campo e Instrumentos desenvolvidos para espalhar uniformemente a areia.

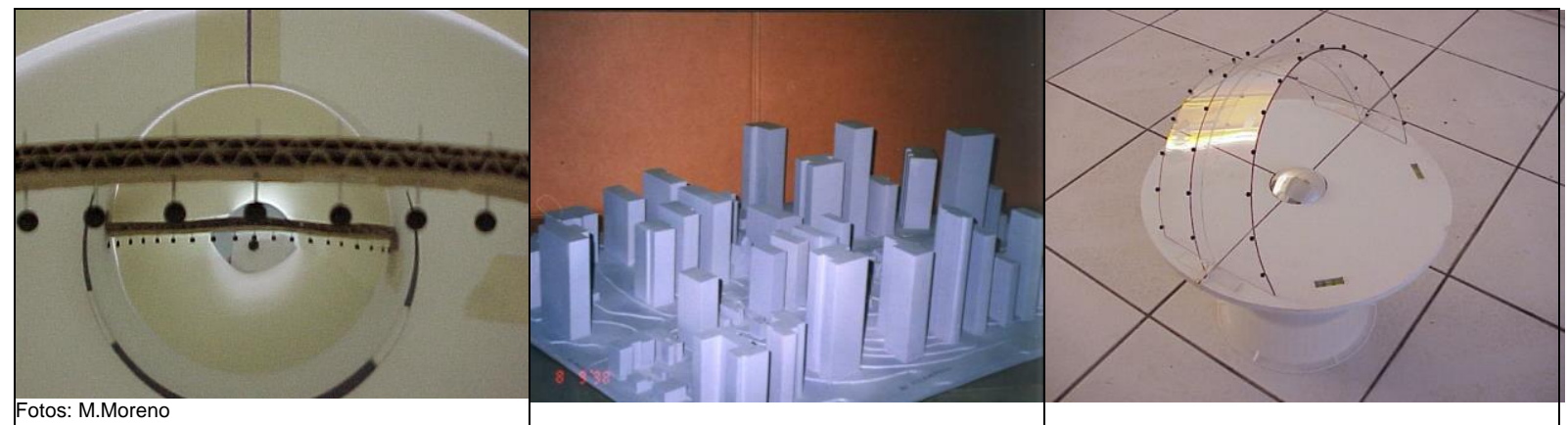

Figura 4-32: Teste para determinação do tipo de projeção produzida pela esfera espelhada; Maquete de Higienópolis e o Espelho do Céu com as trajetórias do Sol para a latitude de $23^{\circ} 27^{\prime}$ 



\section{Procedimentos e Instrumental de Análise}

Nossa meta é fazer com que os profissionais do projeto assimilem os fenômenos ambientais e os processos físicos envolvidos, de maneira intuitiva. Os conhecimentos intuitivos fluem mais fáceis e rápidos do que os racionais e, portanto, têm mais chances de fazer parte do processo de criação da arquitetura e do urbanismo.

Entender a realidade implica em reproduzi-la em nossa mente, significa imaginar seu funcionamento, qualitativa e quantitativamente. Para ajudar nossa imaginação, freqüentemente lançamos mão de simulações e dentre as alternativas, os procedimentos experimentais que utilizam modelos físicos (maquetes), os quais são percebidos da mesma maneira que percebemos a realidade, estão mais próximos da assimilação intuitiva do que os modelos matemáticos, gráficos ou computacionais.

Como o processo criativo é mais intuitivo ${ }^{78}$ do que racional, a melhor forma para que os profissionais do projeto incorporem os conhecimentos, em especial os tecnológicos, é trazê-los ao plano do sensível.

\subsection{Procedimentos de Análise}

Devemos presenciar os fenômenos diretamente na realidade sempre que possível. Ocorre que nosso corpo não tem equipamentos sensoriais calibrados para avaliações quantitativas, além disso muitos fenômenos são imperceptíveis aos nossos sentidos, por isso, necessitamos de instrumentos de medida. Nossos sentidos não têm a abrangência desejada, razão pela qual

Foto: Miguel Torrero e Carlos Silva

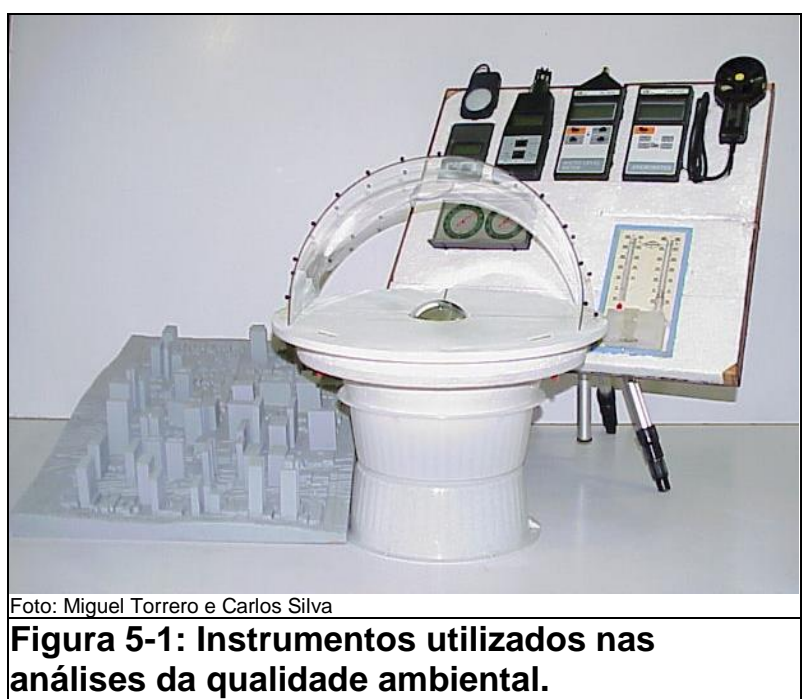
temos que lançar mão de outros equipamentos.

\footnotetext{
78 Intuição: [Do latim tardio intuitione, 'imagem refletida por um espelho'] Ato de ver, perceber, discernir; percepção clara e imediata; discernimento instantâneo; visão. Ato ou capacidade de pressentir; pressentimento: Filos. Apreensão direta, imediata e atual de um objeto na sua realidade individual.
} 
Os principais instrumentos usados para analisar a realidade são nossos sentidos, mas para detectar, quantificar, registrar e reproduzir os aspectos e fenômenos do ambiente natural e urbano, temos que recorrer a outros métodos e equipamentos, e sempre que possível, priorizar as simulações com modelos físicos.

Neste capítulo descrevemos os procedimentos adotados e uma descrição dos equipamentos utilizados, inclusive detalhando aqueles por nós desenvolvidos.

\subsubsection{Levantamento Morfológico}

O reconhecimento físico, pessoalmente das áreas de estudo é fundamental, porém, para selecionar essas áreas necessitamos ter uma visão do conjunto, que em nosso caso é a área metropolitana de São Paulo, e portanto, só pode ser captada, em sua totalidade, através de alguma representação.

Iniciamos o levantamento examinando os mapas cartográficos da EMPLASA nas escalas 1:100.000 e 1:10.000, para analisar a morfologia natural e os tipos de relevo; e também imagens de satélite do INPE para verificar a abrangência da urbanização na Região Metropolitana da Grande São Paulo.

A escolha das áreas verticalizadas para estudo ocorreu a partir do mosaico de fotos aéreas da BASE Aerofotogrametria S.A, obtidas através de vôos em abril de 1996 e agosto de 1997. Inicialmente selecionamos dezessete áreas ${ }^{79}$, todas elas visitadas, fotografadas e mapeadas tendo por base as plantas cadastrais da EMPLASA em escala 1:2.000.

Os levantamentos permitiram reconhecer a morfologia natural: relevo, bacias, corpos d'água, orientação e declividade das vertentes; e a morfologia urbana: arruamentos, parcelamento do solo, espaços livres, volumetria das edificações, permeabilidade do solo, características das superfícies e densidade da vegetação. Todo este material permitiu realizar uma análise macro da situação ambiental da cidade de São Paulo, originando os mapas de caracterização física e ambiental de São Paulo, que estão no anexo A e serviram de base para as análises e recomendações feitas no capítulo 3.

\footnotetext{
79 As dezessete áreas visitadas foram: Centro: Higienópolis; Norte: Freguesia do Ó, Mandaqui e Santana; Sul: Vila Andrade, Real Parque, Vila Mascote, Moema, Monções, Chácara Klabin, Bosque da Saúde; Leste: Vila Luzitana, Vila Gomes Cardim e Jardim Anália Franco; Oeste: Jardim Rizzo, Pacaembu e Perdizes.
} 
Para realizar estudos mais específicos, elegemos cinco áreas ${ }^{80}$ que têm a verticalização mais consolidada, uma em cada zona da cidade, centro, norte, sul, leste e oeste. Os levantamentos dessas áreas podem ser vistos no anexo B e subsidiaram as análises apresentadas no capítulo 4.

\subsubsection{Quantificação das Variáveis Ambientais}

Delimitamos o âmbito das análises atendo-nos às variáveis da morfologia do suporte: natural e urbano e às do ar, enquanto ambiente que envolve as pessoas: higiene ambiental e clima.

Definidas as variáveis, fizemos as análises balizadas por dois pontos de vista: as relações sensoriais do ser humano com seu ambiente físico e os aspectos da qualidade ambiental alterados pela ação da arquitetura e do urbanismo; examinado na macro-escala no capítulo 3 e no capítulo 4 estudado na micro-escala.

Além das variáveis morfológicas tanto naturais como urbanas, o Arquiteto também deve ter condições de avaliar e medir os aspectos ambientais que sua atividade pode alterar em curto prazo, tais como: lluminação, Ruídos, Insolação, Ventos, Umidade e Temperaturas. Como referência para as medições locais, trabalhamos com as normais climatológicas, séries 1931 a 1960 e de 1961 a 1990 do $7^{\circ}$ Distrito de Meteorologia do Ministério da Agricultura e dados climáticos da década 1981 a 1990 do Instituto Astronômico e Geofísico da Universidade de São Paulo.

As variáveis Odores, Gases, Materiais Particulados, Lixo e Sujeira, não têm a Arquitetura como causa principal, devendo ser tratadas pelo conjunto da sociedade. Os odores não têm normas nem equipamentos que permitam análises criteriosas; os levantamentos

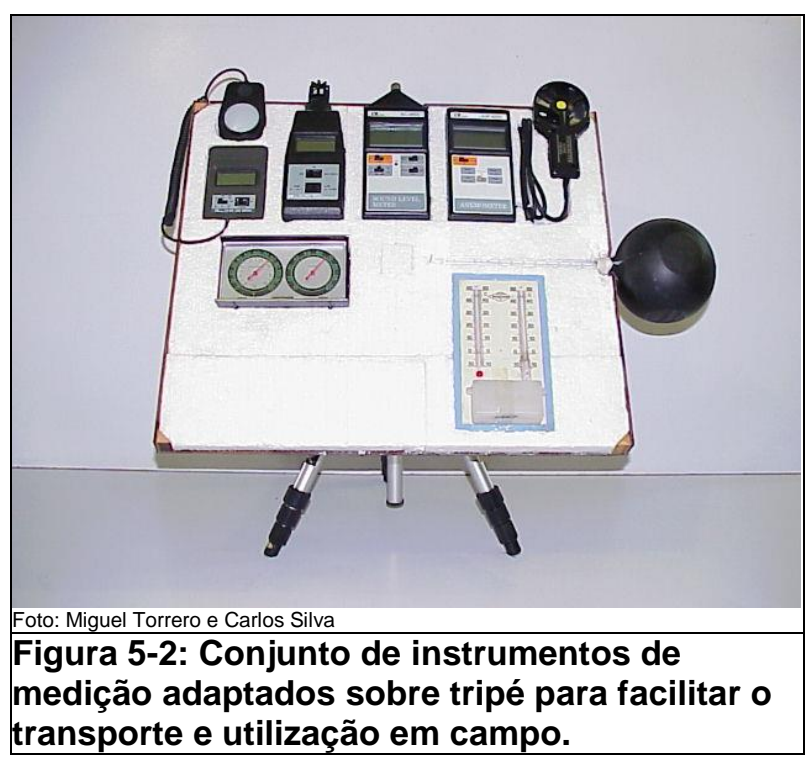

transporte e utilização em campo. dos gases e partículas no ar são amostrados pela CETESB e disponibilizados

${ }^{80}$ Centro: Higienópolis; Norte: Freguesia do Ó; Sul: Moema; Leste: Vila Gomes Cardim; Oeste: Perdizes. 
diariamente na internet; quanto ao lixo e sujeira temos a quantificação e composição do lixo domiciliar recolhido pelo departamento de limpeza pública, mas não há dados sobre o lixo espalhado pelas áreas livres e corpos d’água.

\subsection{Instrumental}

Sempre que possível procuramos utilizar e aprimorar equipamentos simples de baixo custo, imaginando que sejam utilizados pelo profissional do projeto no seu dia a dia. O desenvolvimento e generalização da eletrônica têm permitido obter aparelhos digitais econômicos e confiáveis como luxímetro, termo-higrômetro, decibelímetro e anemômetro, por nós utilizados. O termômetro de globo e o psicrômetro de Augusto são fáceis de construir, pois dependem basicamente de termômetros.

Quanto aos softwares que utilizamos, com exceção das equações de Fanger disponibilizadas em um programa fornecido pelo IPT, os outros são relativamente comuns e são usados normalmente nos escritórios de Arquitetura como o AutoCad, o 3Dstudio e a planilha de cálculo Excel.

\subsubsection{Iluminação}

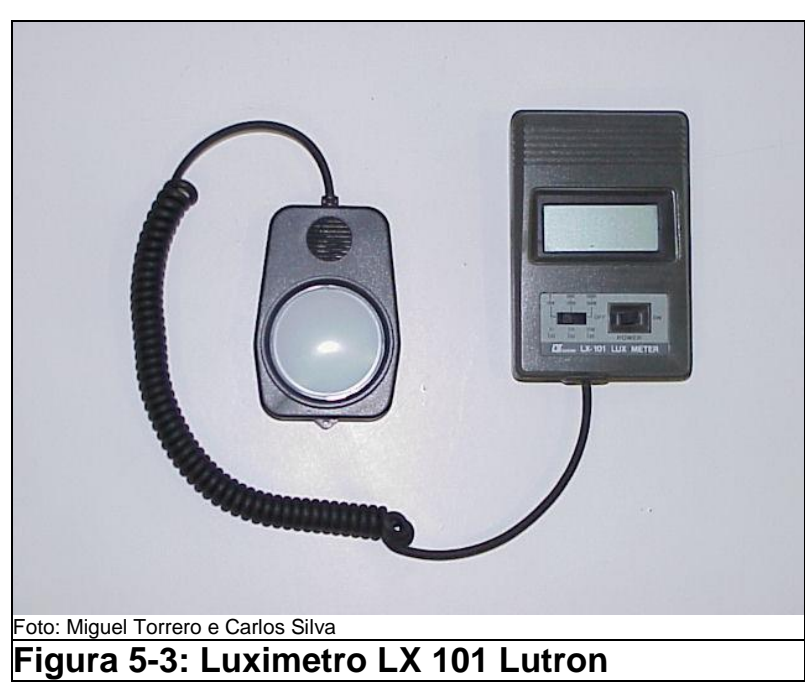

A iluminância incidente em um local pode ser medida utilizando-se um luxímetro digital. Esse equipamento mede a iluminância (lux), que é o fluxo luminoso (lúmen) por unidade de área $\left(\mathrm{m}^{2}\right)$.

Ao fazer as medições tivemos o cuidado de posicionar o sensor horizontalmente, a uma altura de $1,20 \mathrm{~m}$ e trabalhamos com a média de medições feitas em três pontos próximos.

Além de medições pontuais, é necessário fazer estimativas dos aclaramentos disponíveis em uma área, para isso é necessário saber as condições de aclaramento da abóbada celeste e determinar a área do céu visível, que corresponde à área que não está obstruída por construções, árvores ou outros impedimentos. 
A área visível do céu pode ser obtida graficamente utilizando sistemas de projeções estereográficas, ortogonais ou eqüidistante, mas existem outros métodos mais rápidos com o uso de fotografias, principalmente se usarmos câmeras digitais que permitem transferir as imagens imediatamente para o computador.

O método de fotografar a imagem do céu refletida em uma calota esférica, chamado câmara de Robin Hill, apresentado por Olgyay (op.cit.16), data da década de 1950. Vários pesquisadores têm utilizado a parte espelhada de lâmpadas tipo baloon para obter as imagens do céu, entre eles MASCARÓ (op.cit.14) e ASSIS (op.cit.17).

Nosso Espelho do Céu também utiliza uma lâmpada espelhada. Os aperfeiçoamentos estão no

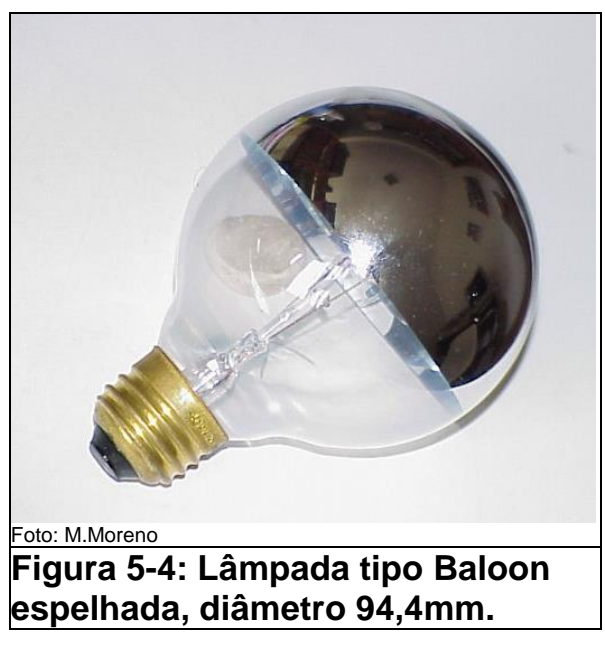
sistema que permite rápido nivelamento mesmo nas superfícies muito inclinadas, nas marcações para a correta orientação em relação ao norte geográfico e o uso da projeção eqüidistante.

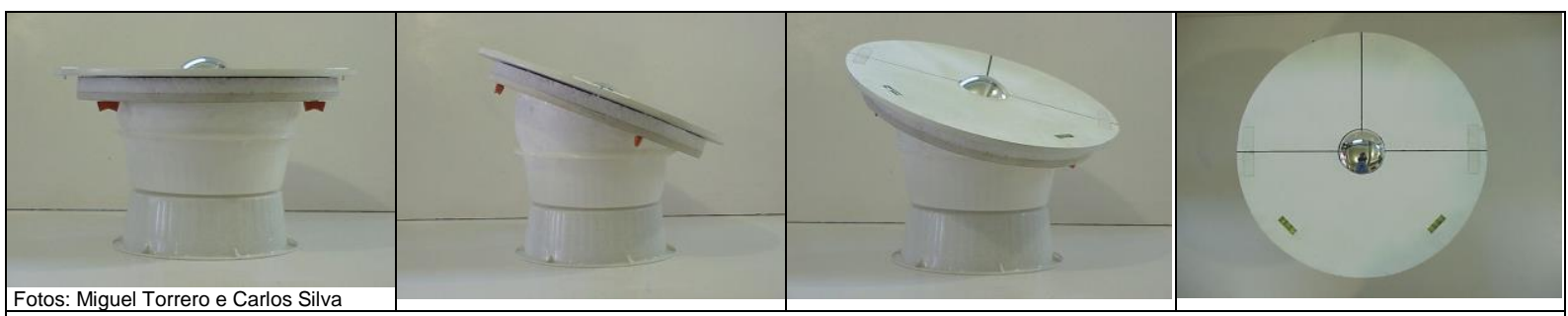

Figura 5-5: Espelho do Céu, adaptação da câmara de Robin Hill, permite fotografias da abóbada celeste, em projeção eqüidistante. Rápido nivelamento em superfícies inclinadas.

Geometricamente, as imagens vistas na esfera espelhada e captadas pela projeção cônica da câmera fotográfica não são estereográficas. Para detectar qual é a projeção que obtemos nas fotos do Espelho do Céu fizemos um experimento constituído de um arco de papelão com marcadores a cada dez graus e examinamos as imagens obtidas, nas quais constatamos tratar-se de projeção eqüidistante.

A partir dessa constatação, elaboramos outro diagrama de distribuição de iluminâncias provenientes do céu em projeção eqüidistante, que embora seja equivalente ao tradicional Gráfico dos 1004 pontos ${ }^{81}$ que é construído em projeção

\footnotetext{
81 Diagrama dos 1004 pontos, em projeção estereográfica, que representa a distribuição da luz difusa proveniente da abóbada celeste, conforme distribuição das iluminâncias do céu padronizado da CIE - Comission Internationele d'Eclairage.
} 
estereográfica, tem a vantagem de ser sobreposto diretamente nas fotos do Espelho do Céu.

Um equívoco é adotar diagramas estereográficos para interpretar as imagens eqüidistantes obtidas com a esfera espelhada.
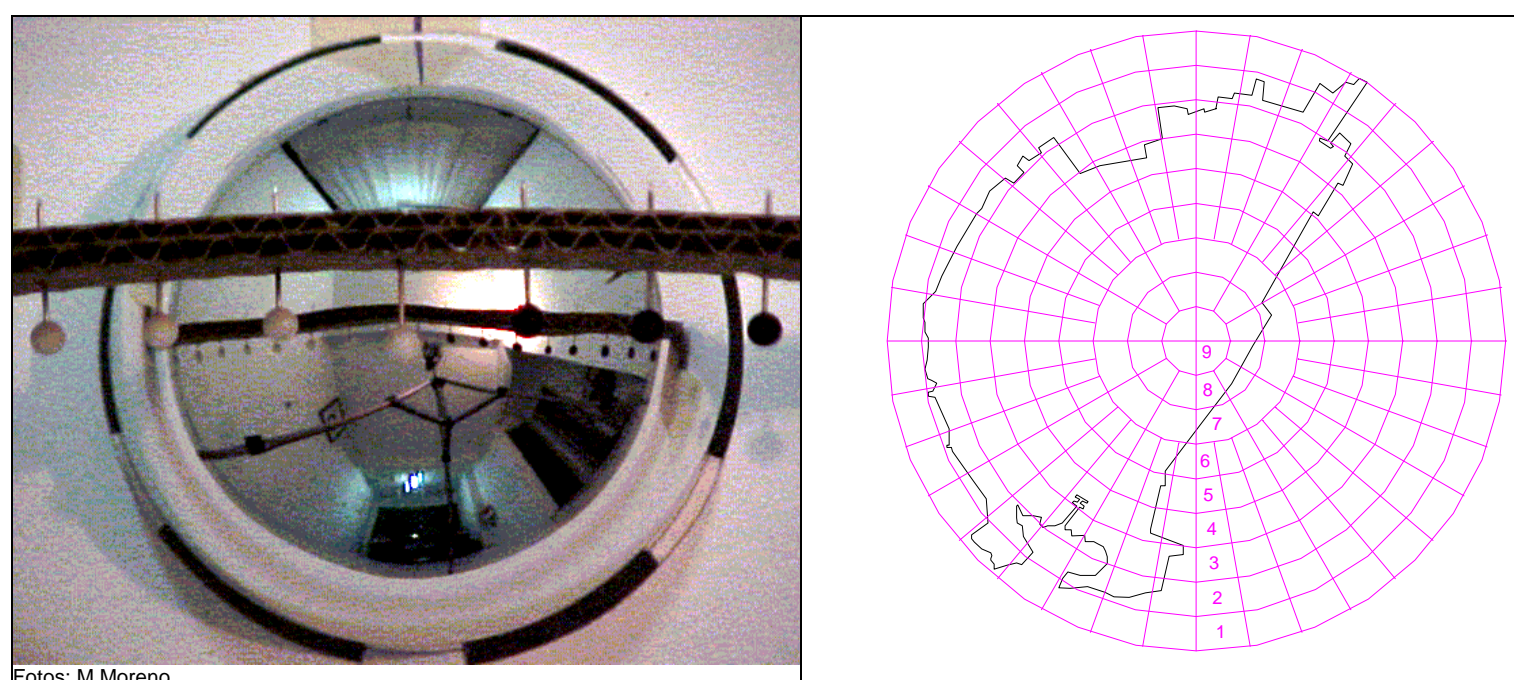

Figura 5-6: Espelho do Céu com o experimento para determinar o tipo de projeção e Diagrama de distribuição de iluminâncias em projeção eqüidistante.

Se considerarmos a área do círculo do diagrama igual a 100(cem), cada porção numerada de 1 a 9 terá a seguinte porcentagem de aclaramento:

\begin{tabular}{|c|c|c|c|c|c|c|c|c|c|}
\hline Legenda & 1 & 2 & 3 & 4 & 5 & 6 & 7 & 8 & 9 \\
\hline $\begin{array}{c}\% \text { por } \\
\text { parte }\end{array}$ & 0,0837 & 0,2411 & 0,3695 & 0,4532 & 0,4823 & 0,4532 & 1,1085 & 0,7235 & 0,7538 \\
\hline $\begin{array}{l}\mathbf{N}^{\circ} \text { partes } \\
\text { por volta }\end{array}$ & $\mathrm{X} 36$ & $\mathrm{X} 36$ & $\mathrm{X} 36$ & $\mathrm{X} 36$ & $\mathrm{X} 36$ & $\mathrm{X} 36$ & $\mathrm{X} 12$ & $\mathrm{X} 12$ & $\mathrm{X} 4$ \\
$\begin{array}{c}\% \text { por } \\
\text { volta }\end{array}$ & 3,0153 & 8,6824 & 13,3022 & 16,3175 & 17,3648 & 16,3175 & 13,3022 & 8,6824 & 3,0153 \\
\hline
\end{tabular}

As análises de iluminação apresentadas no capítulo anterior foram feitas a partir de cada foto, desenhando-se a área do céu visível com o AutoCad. Sobre a área de céu visível, calculou-se a porcentagem de distribuição dos aclaramentos, a qual multiplicada pela iluminância de referência fornece a iluminância naquele ponto.

Este procedimento permite fazer estimativas de aclaramentos futuros, após a implantação de construções, subtraindo-se da área de céu visível a áreas das obstruções que serão construídas. 


\subsubsection{Ruído}

A potência sonora de um local pode ser medida utilizando-se um decibelímetro digital. Esse equipamento mede o Nível Sonoro de Intensidade em decibéis $(\mathrm{dB})$.

Ao fazer as medições tivemos o cuidado de posicionar o microfone do aparelho a altura do aparelho auditivo de uma pessoa de altura mediana, 1,50m.

O equipamento permite optar pelas escalas $A$ e $C$; nas medições utilizamos a escala $A$ como recomendado pelas normas, em especial a NBR10151/2000 (orig. NB1095): Acústica - avaliação do ruído em áreas habitadas, visando o conforto da comunidade -

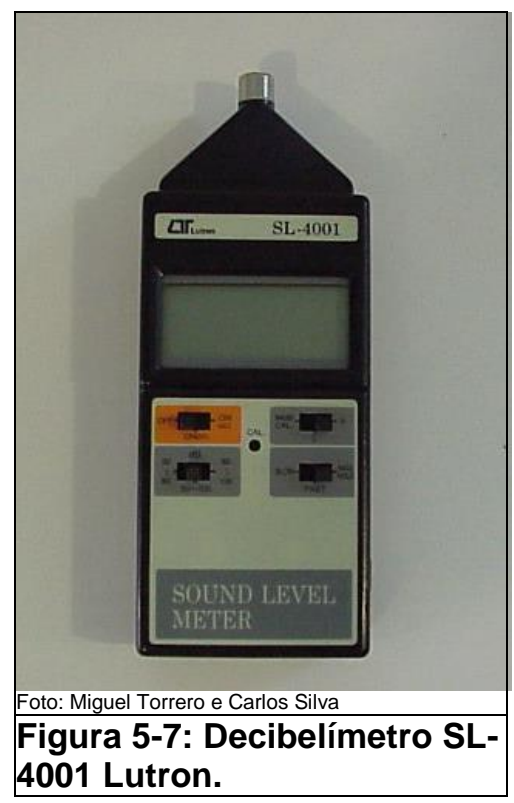
procedimentos.

\subsubsection{Insolação}

Os instrumentos utilizados para simular e avaliar a insolação foram determinados em função de cada experimento:

Maquetes: para simular as trajetórias do Sol, utilizamos maquetes que reproduziam em escala trechos do tecido urbano. Para estes estudos, a escala 1:1000 é suficiente, embora quanto maior for o modelo maior o grau de precisão e detalhes.

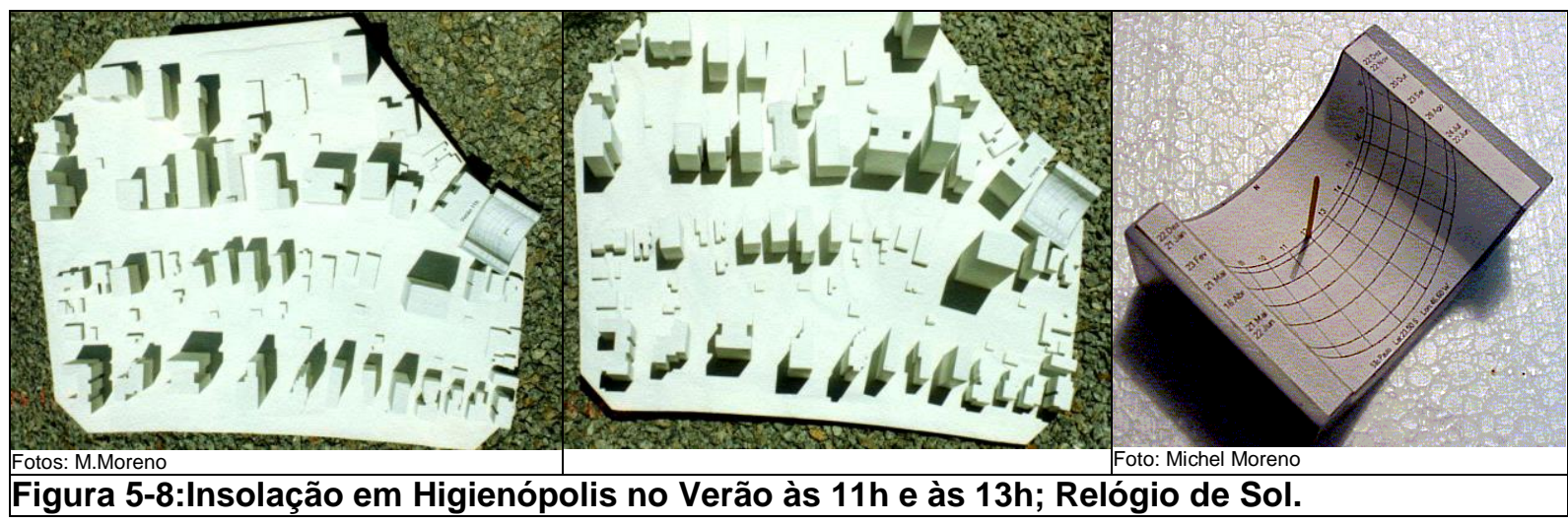

O procedimento consistiu em fixar o relógio de Sol na maquete na direção exata do Norte Geográfico e posicionar o conjunto ao Sol. Mudando-se as inclinações, do conjunto, alteram-se as datas e os horários conforme indicado pela sombra no 
relógio de Sol. Fotografamos as maquetes de hora em hora para o inverno e também para o verão.

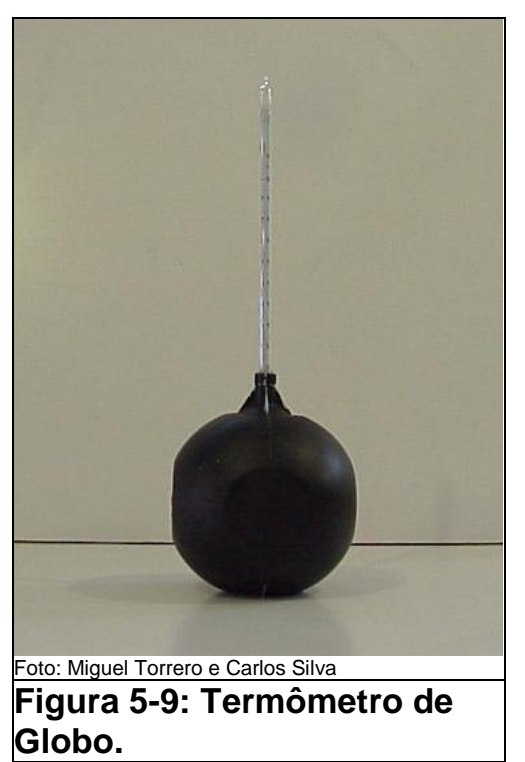

Termômetro de Globo: A finalidade deste instrumento é medir a Temperatura Radiante Média (TRM), que corresponde à média das radiações recebidas das superfícies do entorno e também do Sol.

É constituído de um termômetro de mercúrio cujo bulbo fica no centro de uma esfera de cobre, com $15 \mathrm{~cm}$ de diâmetro, pintada de preto fosco.

Os resultados das medições realizadas foram utilizados, juntamente com outras variáveis para avaliar o nível de conforto térmico através das equações de Fanger.

Espelho do Céu: O mesmo equipamento desenvolvido para os estudos de iluminação também serve para determinar as estações e horários em que o ponto em estudo receberá Sol.

Para tanto implementamos em material transparente as trajetórias do Sol para a latitude de $23^{\circ} 27^{\prime}$ Sul, para serem colocadas sobre o Espelho do Céu.
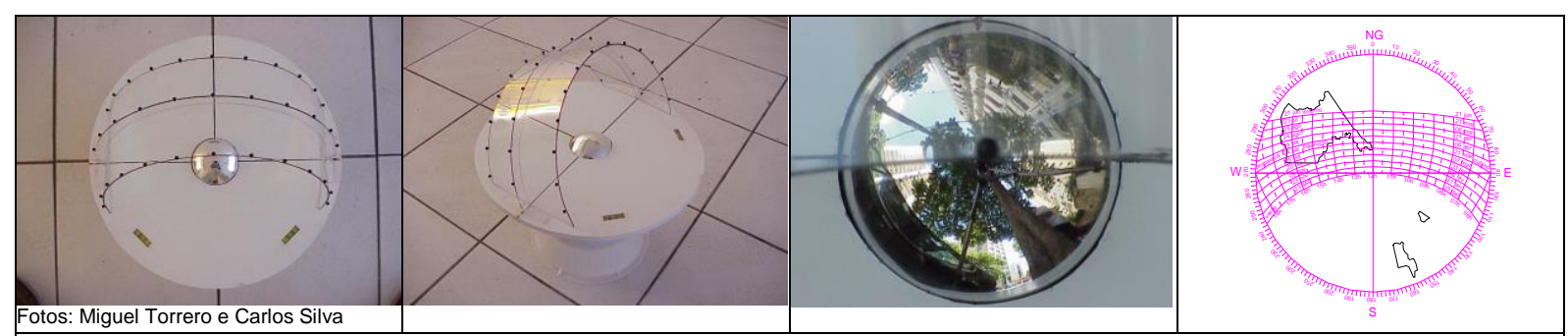

Figura 5-10: Espelho do Céu com as trajetórias do Sol para o Trópico de Capricórnio e desenho em AutoCad.

Através desse artifício, as fotos mostram a porção do céu visível e as trajetórias do inverno, equinócios e verão.

Mesmo nas fotos sem as trajetórias, é possível sobrepor o diagrama eqüidistante das trajetórias aparentes do Sol para a latitude em estudo, através de programas de computação gráfica de tratamento de imagens ou de cad. 


\subsubsection{Ventos}

As medições das velocidades dos ventos nos pontos estudados foram feitas com um anemômetro digital de ventoinha. Os cuidados nas medições consistiram em levantar a ventoinha à $2 \mathrm{~m}$ acima do piso.

Os dados obtidos serviram para confrontar os testes feitos em túnel atmosférico (ver item 5.2) e também entraram nos cálculos de Figura 5-11: Anemômetro AM4201 Lutron conforto térmico.

\subsubsection{Umidades e Temperaturas}

A umidade relativa do ar foi medida com três equipamentos diferentes: Termo Higrômetro digital HT-3001C Lutron, Psicrômetro de Augusto e Termômetro e Higrômetro bimetálicos conjugados.

Pretendíamos utilizar apenas o aparelho digital, porém, como tivemos problemas de calibração e constatamos diferenças significativas, optamos por priorizar as medidas obtidas com o psicrômetro de Augusto, mesmo implicando em ter que usar a carta psicrométrica para obter os resultados.

O Termômetro e Higrômetro Sunbean, serviram apenas como referência. As temperaturas e umidades obtidas entraram nos cálculos do conforto térmico.

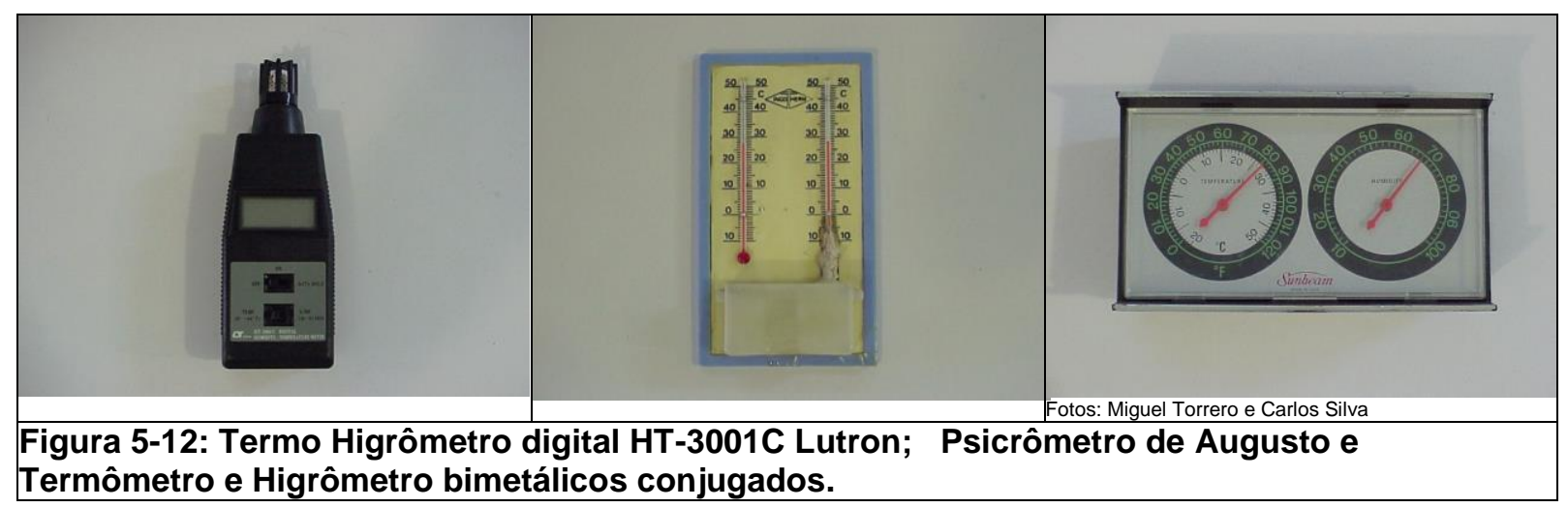




\subsection{Túnel de Vento de Camada Limite Atmosférica}

Os métodos experimentais, utilizando maquetes, são uma reprodução laboratorial dos fatos e permitem reproduzir, medir e visualizar a realidade. Como qualquer outra simulação, implica focalizar alguns aspectos, em detrimento de outros, mas são mais próximos da realidade do que os modelos matemáticos ou as simulações computacionais.

Existem dois tipos de Túneis de Vento: Os Túneis Aerodinâmicos, nos quais o ar flui laminarmente, sem turbulências e com velocidade uniforme e que são utilizados para testes em altas velocidades, como por exemplo, no desenvolvimento de aeronaves e outros veículos. Os Túneis de Camada Limite Atmosférica ou simplesmente Túneis Atmosféricos reproduzem a movimentação da atmosfera próxima à superfície, onde o ar flui com velocidades tanto menores quanto mais próximo do solo, em função da quantidade e altura de obstáculos, como o relevo, as edificações ou a vegetação, existentes na superfície.

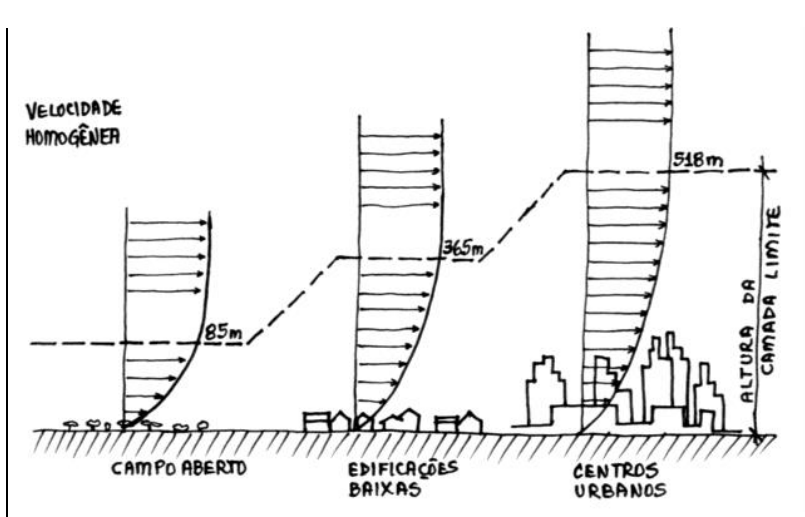

Figura 5-13: Camada Limite Atmosférica; Perfis de Velocidades.
A camada em que 0 ar flui em velocidades menores, por influência da rugosidade (obstáculos) existentes na superfície, é chamada Camada Limite Atmosférica. Graficamente, através do Desenho de Vetores de Velocidades, podemos mostrar o vento, quando corre livremente e como se comporta dentro da Camada Limite.

Segundo o Engenheiro Civil, Professor da UFRS, Joaquim BLESSMANN ${ }^{82}$, Francis Herbert Wenham, na Inglaterra, construiu o primeiro túnel aerodinâmico. Entre 1891 e 1894, na Universidade de Melbourne, Austrália, Kernot e Mann, desenvolveram uma série de pesquisas com modelos de cubos, pirâmides, cones, chaminés, telhados, vigas, etc, em um pequeno túnel de secção transversal $30,5 \mathrm{~cm} \times 30,5 \mathrm{~cm}$, sendo o vento gerado por um ventilador. Os primeiros túneis foram construídos para o estudo de modelos de construções e sólidos geometricamente simples. Com o

\footnotetext{
82 BLESSMANN, Joaquim (@1983) - Aerodinâmica das Construções, 2ª ed., Porto Alegre, Sagra, 1990. (p.110)
} 
advento da aviação, os túneis aerodinâmicos têm progredido ao ritmo da vertiginosa expansão da aeronáutica.

\subsubsection{O Uso de Túneis de Vento em Geral}

Até a metade do século $X X$, raros são os estudos da ação dos ventos nas edificações. Em 1933, Dryden e Hill publicaram os estudos feitos com um modelo do Empire State Building.

Segundo BORGES, pesquisador do LNEC (Laboratório Nacional de Engenharia Civil) ${ }^{83}$, a total destruição, em 1940, pela ação do vento, da ponte pênsil Tacoma Narrows, nos Estados Unidos, iniciou uma nova fase na aplicação da aerodinâmica na engenharia civil. Kármán, Ackeret e outros, passaram a estudar o comportamento de modelos de tabuleiros de pontes suspensas, em túneis de vento.

As torres de refrigeração das grandes usinas termoelétricas são importantes estruturas com formas cilíndricas. Em 1965, três grandes torres de refrigeração da Central Térmica de Ferrybridge, na Inglaterra, ruíram sob a ação do vento. Owen estudou, em túnel de vento, as causas e mostrou que quando as torres estão agrupadas como em Ferrybridge, a interferência aerodinâmica entre elas modifica a freqüência e amplitude das oscilações eólicas com maior intensidade do que ocorreria com uma torre isolada.

Os testes com modelos de edificações têm sido feitos em túneis aerodinâmicos específicos para estudos aeronáuticos; os resultados são questionáveis, pois esses túneis têm escoamento laminar com fluxo de ar uniforme e sem turbulência; e nisto diferem do vento natural, que além de ser turbulento, têm importantes aumentos de velocidades com a altura.

No Brasil, alguns fatos recentes (1998), ocasionados pelo vento, como a queda de algumas torres das linhas de transmissão de Itaipu no estado do Paraná, as fortes oscilações da Ponte Rio-Niterói, a queda de parte de uma antena sobre um edifício na Avenida Paulista, assim como vários danos às construções no interior de São Paulo, principalmente em Rio Claro, mostram a necessidade de estudos mais aprofundados em túneis de vento atmosféricos que reproduzam adequadamente o perfil de velocidades da camada limite do vento natural.

83 BORGES, A. R. Janeiro - O Túnel Aerodinâmico do Laboratório Nacional de Engenharia Civil, Lisboa, LNEC, 1968. (p.1) 


\subsubsection{Aplicações de Túneis de Vento Atmosféricos}

Os túneis de vento atmosféricos têm aplicações práticas em diversas áreas:

Projeto de Edificações e Estruturas: A procura de resultados mais fiéis originou o desenvolvimento de diversas técnicas de simulação de características dos ventos naturais em laboratório. Por sua vez, uma maior precisão dos resultados tornou-se importante nos últimos anos, à medida que o desenvolvimento arquitetônico e estrutural permitiu a construção de edificações mais arrojadas, leves e esbeltas.

Entre os fatores que tornaram necessário um estudo mais preciso da ação do vento sobre as edificações, citamos:

a) Novas formas e proporções arquitetônicas, com características aerodinâmicas diferentes das usuais, como por exemplo, as enormes coberturas de pavilhões de exposições;

b) Como as construções atuais são muito mais leves, sua densidade tem diminuído de um modo acentuado; conseqüentemente, os efeitos do vento tornaram-se proporcionalmente muito mais significativos;

c) Certos sistemas estruturais, aliados à diminuição da carga, apresentam um amortecimento muito pequeno, tornando as estruturas muito sensíveis a oscilações causadas pelos ventos;

d) Os computadores ao permitir métodos de análise estrutural mais precisos, nos obrigam, coerentemente, a um melhor conhecimento das forças atuantes na estrutura, inclusive as produzidas pelos ventos.

Qualidade e Proteção Ambiental: No planejamento para a implantação de instalações industriais; na redução da recirculação de ar viciado dentro das edificações; na localização de reservatórios de gás ou produtos químicos; na distribuição de assentamentos sobre terrenos complexos; avaliação de riscos por derramamentos tóxicos, inflamáveis ou substâncias radioativas; destruição ou danos em fachadas de vidro ou telhados; efeitos sobre pedestres, árvores ou veículos; ruídos e assobios gerados pelo vento entre edifícios próximos; entrada de fumaça em edifícios, liberada por chaminés próximas ou por incêndios; avaliação da distribuição de aberturas em fachadas; estudo dos ventos rápidos gerados pela 
passagem do ar entre edifícios altos, ou ao nível dos pilotis; danos ou derrubada de painéis de propaganda; ventilação em túneis rodoviários e ferroviários.

Proteção e Conforto Humanos: No controle do vento ao nível dos pedestres, próximo a grandes edifícios; na limitação das oscilações dos edifícios altos; no controle dos ventos em estádios e campos esportivos; na proteção de áreas de trabalho ao ar livre; na estabilidade de veículos.

Poluição: Determinação da altura de dispersão de emissões de chaminés; efeitos das queimadas de canaviais nas cidades próximas; efeitos dos incêndios florestais; efeitos dos ventos e inversões térmicas na dispersão dos poluentes; testes de intervenção urbana através de árvores e painéis para evitar os focos de estagnação de poluentes; simulação em modelos reduzidos, de trechos urbanos para estudar a geração de poluentes e sua propagação; efeitos de bloqueio e canalização de ventos em bacias hidrográficas.

Caracterização da Circulação Atmosférica: Determinação da camada limite do vento; furacões; tornados; ventos no sopé de encostas; caracterização de valores extremos; análises de probabilidades de ocorrências.

Produção Energética: Sistemas de conversão de energia do vento; efeitos da topografia sobre os equipamentos para aproveitar a energia eólica; embarcações à vela.

Produção Agrícola: Estruturas de proteção contra os ventos; dispersão de inseticidas e fertilizantes por pulverização aérea; padrões de cultivo para eficiente polimerização de grãos híbridos; controle das concentrações de dióxido de carbono; proteções contra geadas.

\subsubsection{A Parceria com o Laboratório de Vazão do IPT}

A crescente urbanização e verticalização das cidades provocam alterações, nos ventos, que prejudicam a habitabilidade nos espaços livres; seja pela formação de redemoinhos, que concentram poeiras e gases ou pela produção de incômodos ventos encanados. Nosso interesse pelo estudo da influência da ventilação na habitabilidade dos espaços arquitetônicos e urbanísticos, data de muitos anos, quando ainda estudante, e acreditamos que o túnel de vento atmosférico é uma das melhores ferramentas para estudar esses problemas. 


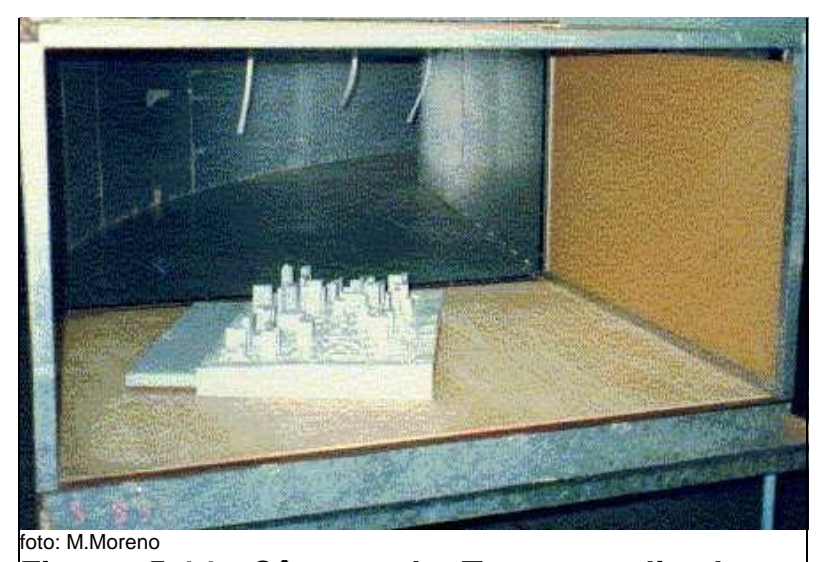

Figura 5-14: Câmara de Testes realizada na Universidade Paulista.
As preocupações com a ventilação, se fortaleceram quando iniciamos nossa carreira docente, no $3^{\circ}$ grau, em 1975, como professor de Higiene das Habitações no Curso de Arquitetura da Universidade Brás Cubas, junto com os professores Luiz Carlos Chichierchio e Roberto Stark Nogueira da Silva e, já naquela época, analisávamos a

ventilação no interior das construções, um pavimento de cada vez, utilizando um túnel de vento rudimentar, que nada mais era do que uma caixa cúbica de acrílico transparente, de $80 \mathrm{~cm}$ de lado e um grande ventilador. Colocávamos maquetes (escala 1:50), cheias de bolinhas de isopor de $1 \mathrm{~mm}$ de diâmetro e a título de cobertura, um vidro. Com a maquete posicionada na direção dos ventos predominantes, ao acionar o ventilador, as bolinhas eram removidas do caminho percorrido pelo fluxo de ar, permitindo visualizar e fotografar as trajetórias dos ventos. Nas partes do recinto em que o ar ficava parado, o isopor se acumulava estagnado. As áreas sem o isopor indicavam os caminhos por onde o ar fluía livremente.

Para estudar a ventilação em áreas verticalizadas, em 1997, construímos uma Câmara de Testes para ser acoplada ao equipamento usado para estudar perfis aerodinâmicos, do laboratório de Mecânica dos Fluidos da Universidade Paulista. Nossa intenção foi utilizar o método das bolinhas de isopor em maquetes de trechos verticalizados do tecido urbano.

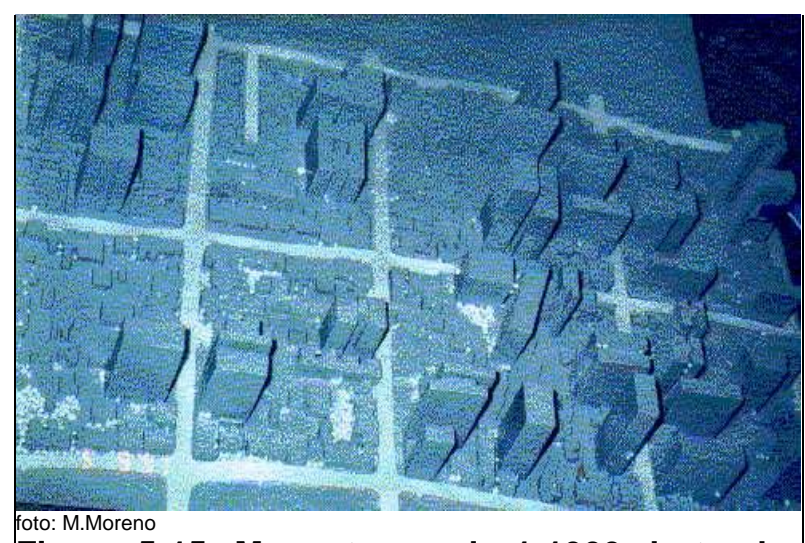

Figura 5-15: Maquete escala 1:1000 de trecho do bairro das Perdizes, com as bolinhas de isopor.
Construímos um modelo, na escala 1:1000, de oito quarteirões do bairro das Perdizes, uma das áreas mais verticalizadas de São Paulo, abrangendo as ruas: Ministro Ferreira Alves, Desembargador do Vale, Coronel Melo Oliveira, Cotoxó, Tucuna, Caraíbas, Diana e Caiovaá. Esse modelo tinha duas finalidades: fazer estudos de 
insolação com o uso de relógio de sol e os estudos dos ventos nos espaços livres utilizando túnel de vento.

Os estudos de insolação chegaram a bons resultados, permitindo visualizar claramente os sombreamentos nas várias estações e horários durante 0 ano. Quanto aos estudos de ventilação, os experimentos não permitiram observar o comportamento dos ventos entre as edificações por vários motivos; entre eles, a curvatura na câmara de testes que causou redemoinhos e a inadequação da escala da maquete, que se mostrou muito pequena para esse tipo de estudo.

No início de 1998, tomamos conhecimento da existência de um túnel de vento no Instituto de Pesquisas Tecnológicas. Em 25 de março do mesmo ano, tivemos a primeira conversa com o Prof. Dr. Marcos Tadeu Pereira, Engenheiro Chefe do Laboratório de Vazão do Instituto.

O Laboratório de Vazão é constituído

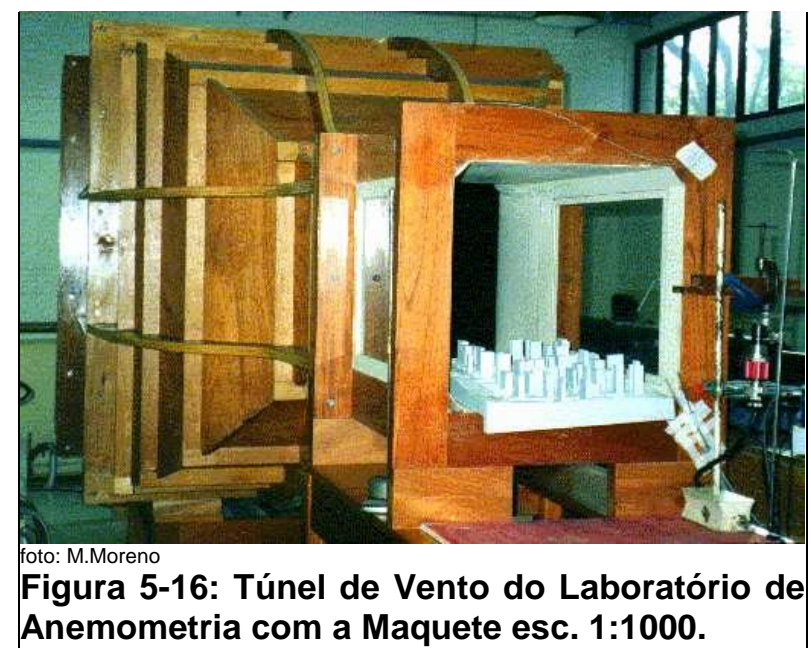
por sete laboratórios dedicados: 1. Gás, 2. Água, 3. Óleo, 4. Anemometria, 5. Higrometria, 6. Ventiladores e 7. Bombas.

No Laboratório de Anemometria há um Túnel de Vento para velocidades de $2 \mathrm{~m} / \mathrm{s}$ a $30 \mathrm{~m} / \mathrm{s}$, com secção de testes de $50 \mathrm{~cm} \times 50 \mathrm{~cm}$, sendo normalmente utilizado para calibrar instrumentos de precisão.

Como nossa maquete escala 1:1000 mede $50 \mathrm{~cm} \times 80 \mathrm{~cm}$, ficaria inviável estudar o comportamento dos ventos oriundos de várias orientações.

O Laboratório de Ventiladores tem três Câmaras de Bocais: a CB1 para baixas vazões de 50 a $1000 \mathrm{~m}^{3} / \mathrm{h}$; a CB2 para médias vazões de 1000 a $12000 \mathrm{~m}^{3} / \mathrm{h}$; e

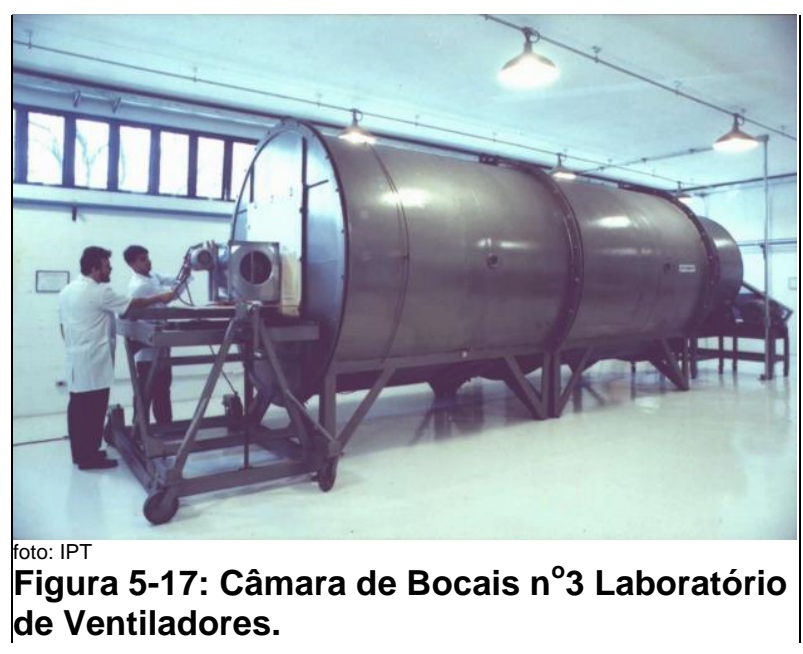

a CB3 para altas vazões de 2000 a $45000 \mathrm{~m}^{3} / \mathrm{h}$, utilizadas principalmente para testar ventiladores e exaustores dos mais diversos tamanhos. O Prof. Marcos Tadeu 
aventou a possibilidade de construirmos uma Câmara de Testes para ser acoplada à Câmara de Bocais nํ 3, servindo esta última para puxar o ar, em velocidades convenientes através dos modelos.

Aceitamos o desafio, ficando assim implícita uma parceria com a finalidade de assimilar, desenvolver e experimentar conhecimentos, objetivando a futura construção de um Túnel de Vento Atmosférico de grande porte no IPT e em curto prazo substanciar nossa tese de doutorado.

\subsubsection{Construção da Câmara de Testes}

Fizemos diversas reuniões com o Prof. Marcos Tadeu e sua equipe para analisar a melhor forma de viabilizar a construção da Câmara de Testes, que acoplada à Câmara de Bocais $n^{\circ} 3$ formaria o Túnel de Vento. Uma das principais premissas foi que nós mesmos pudéssemos construí-la em uma marcenaria. No final de abril de 1998, chegamos à definição de como deveria ser a Câmara de Testes.

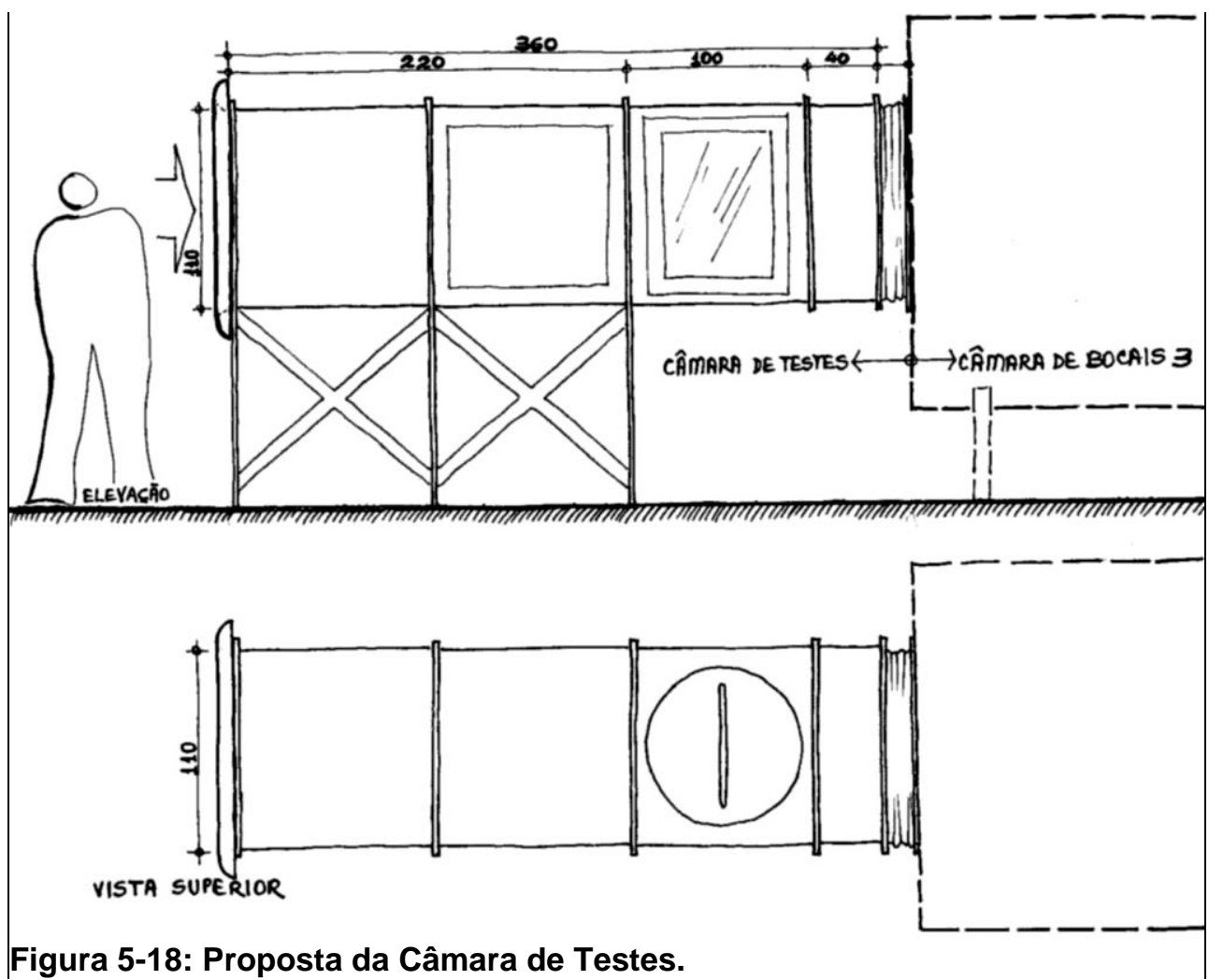

Aspectos Funcionais considerados: a) facilidade de acoplar/desacoplar as duas Câmaras; b) possibilidade de girar o modelo $360^{\circ}$; c) ter superfícies transparentes para visualizar e documentar os testes realizados; d) poder inserir a sonda Laser ou outros equipamentos de medição pela parte superior; e) desenvolver um sistema 
que permitisse posicionar o instrumental para fazer medições em toda a área do modelo.

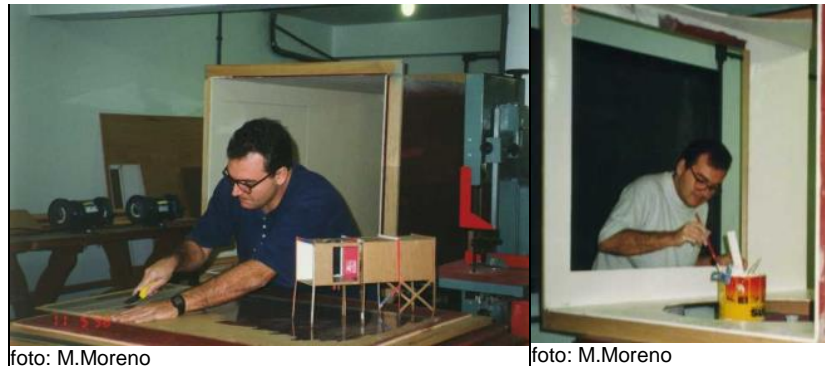

Figura 5-19: Construção da Câmara de Testes.

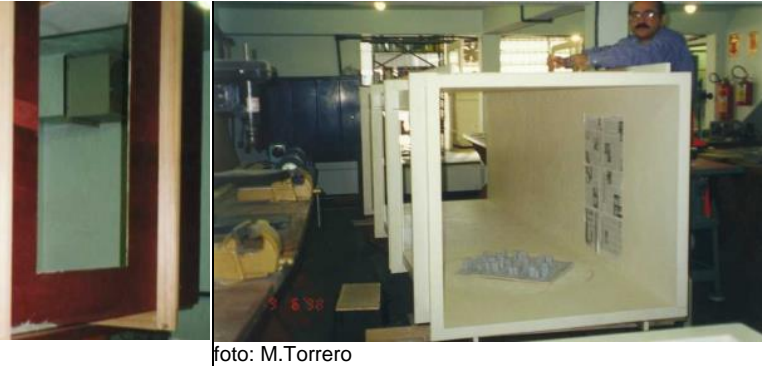

foto: M.Torrero

Aspectos Materiais: a escolha dos materiais, chapas de madeirit e sarrafos de pinho, foi motivada pelo bom domínio que os realizadores têm com esses materiais e a maior disponibilidade de equipamentos para lidar com madeira.

\subsubsection{Aspectos Construtivos}

Como o quadrado de acoplagem na Câmara de Bocais mede 1,2m x 1,2m e as chapas de madeirit têm $1,1 \mathrm{~m} \times 2,2 \mathrm{~m}$, adotamos 1,1m como módulo para construir a Câmara de Testes, ficando a secção interna com 1,09m x 1,09m e o comprimento com $3,6 \mathrm{~m}$, em função do espaço disponível no Laboratório.

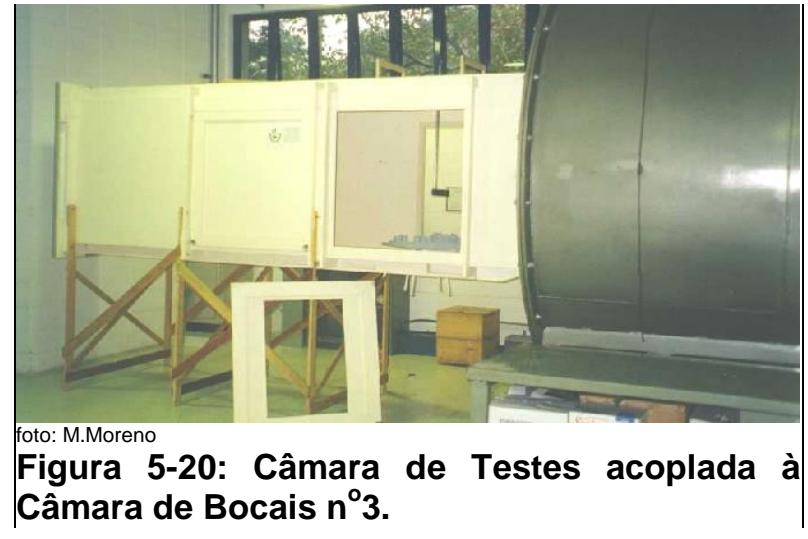

Sarrafos de $2,5 \mathrm{~cm} \times 5,0 \mathrm{~cm}$ foram usados para fazer as 5 nervuras que estruturam 0 conjunto e os pés de apoio.

Efetuamos alguns aprimoramentos após os primeiros ensaios, pois observamos que a Câmara de Bocais transmitia forte trepidação para a Câmara de Testes; por isso, confeccionamos em courvin uma junta flexível que foi instalada entre as duas Câmaras.

Em seguida, colocamos fora, próximo à entrada de ar da Câmara de Testes, placas de madeirit dos dois lados para direcionar os fluxos e tentar equalizar as velocidades do vento, pois a proximidade de paredes junto a um dos lados da entrada provocava acentuadas diferenças nas velocidades.

Em seguida, colocamos duas telas de nylon na entrada para reduzir as turbulências e também ajudar a igualar as velocidades do ar próximo às laterais da Câmara. 
Finalmente, instalamos duas camadas de tecido jérsei entre as duas Câmaras para possibilitar o uso de material particulado, como por exemplo areia, na Câmara de Testes, sem danificar a Câmara de Bocais. Isso é possível porque o tecido permite a passagem do ar, porém, barra a areia.

\subsubsection{Conceitos e Procedimentos}

Para fazer testes de desempenho de aviões, automóveis e outros veículos, utilizamse Túneis de Vento Aerodinâmicos, cuja principal característica é ter o fluxo de ar laminar com velocidades constantes. Outros estudos necessitam os Túneis de Vento Atmosféricos, nos quais é possível reproduzir as velocidades do ar como ocorre na Camada Limite, com turbulências e ventos tanto mais velozes quanto maior for a altitude.

Várias fontes, como: POPE e RAE ${ }^{84}$; BLESSMANN (C1983) ${ }^{85}$; BLESSMANN $1986^{86}$ e $A_{S C E}{ }^{87}$, concordam em afirmar que as forças estáticas devidas ao vento em edificações podem ser estudadas em modelos reduzidos, em escoamento de velocidade e fluido diferentes, desde que se tenham três condições de semelhança: geométrica, cinemática e dinâmica.

\subsubsection{Semelhança Geométrica dos Corpos}

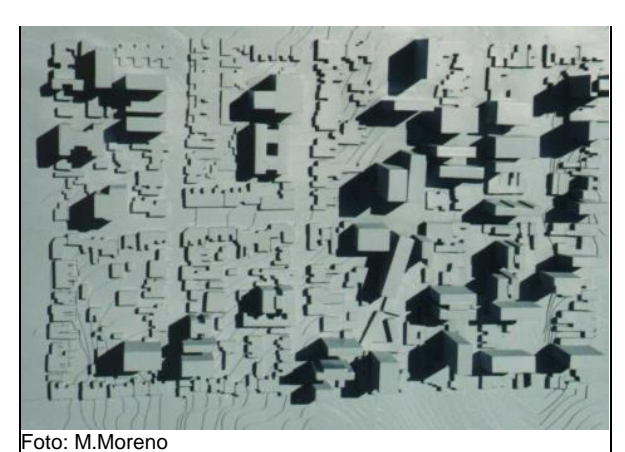

Figura 5-21: Maquete de Perdizes.

Devemos trabalhar com modelos em escala, isto é, a maquete deverá ter proporcionalmente a mesma forma, os mesmos detalhes, a mesma rugosidade das superfícies e a mesma orientação dos ventos, que ocorre na situação real. Matematicamente, a relação entre todas as dimensões no modelo $\left(L_{1}\right)$ e as dimensões reais $\left(L_{2}\right)$ têm que ser constantes, isto é, $L_{1} / L_{2}=$ Constante.

Construção do Modelo escala 1:1000: A primeira maquete, construída pelo Arquiteto Miguel Augusto Torrero, abrangendo oito quarteirões entre o bairro Perdizes e a Pompéia, foi feita na escala 1:1000.

\footnotetext{
84 POPE, Alan e RAE JR., Willian H. - Low-Speed Wind Tunnel Testing, New York, John Wiley \& Sons, 1984. (p. 483 a 522)

${ }^{85}$ BLESSMANN, op.cit (๑1983, p. 62 a 83).

86 BLESSMANN, Joaquim - O Vento na Engenharia Estrutural, CE 10, Caderno de Engenharia 10, Porto Alegre, UFRGS, 1986. (p.16 a 55)

87 ASCE; AEROSPACE DIVISION - Wind Tunnel Studies of Buildings and Structures, Manual of practice - várias cidades dos USA e Canadá, ASCE, 1997. (p 13 a 19 e 34 a 37)
} 
Acostumados a trabalhar a problemática urbana em mapas na escala 1:2000, pareceu-nos que o modelo duas vezes maior seria ótimo. Entretanto, não foi possível visualizar o comportamento do ar entre as edificações e, mesmo os termoanemômetros, que são relativamente pequenos, não couberam entre os prédios da maquete.

Construção de Modelos escala 1:333,33: Com a evolução dos testes, chegamos à conclusão que teríamos que trabalhar com maquetes maiores, escala 1:500, 1:400 ou até 1:300, mesmo que isso implicasse em analisar somente dois ou três quarteirões ao invés dos oito propostos inicialmente. Em função dos $3 \mathrm{~mm}$ de espessura das chapas de duratex, que foi o material escolhido para fazer a topografia das maquetes, chegamos à escala de 1:333,33.
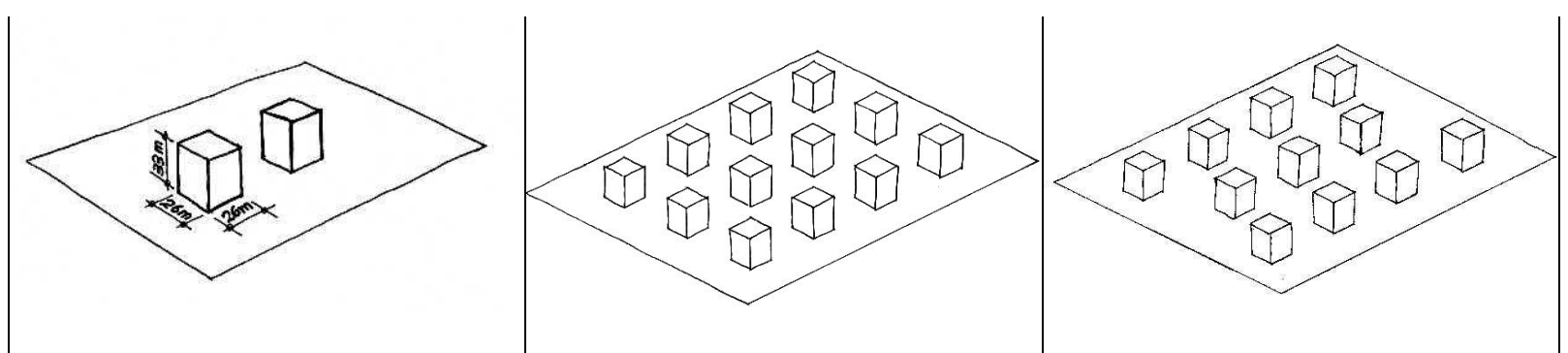

Figura 5-22: Maquetes Básicas com edifício de 26m x 26m x 33m (10 andares) esc.1:333,33.

Num primeiro momento, objetivando assimilar o comportamento dos ventos em situações típicas, e adquirir uma certa sensibilidade na sua interpretação, construímos três maquetes básicas com edifícios de 10 andares $(33 \mathrm{~m})$ e base de $26 \mathrm{~m} \times 26 \mathrm{~m}$, já utilizando a escala 1:333,33: a) Edifício obstruído por outro igual, b) Edifícios iguais alinhados e c) Edifícios iguais desencontrados.

Somente após uma série de testes com esses modelos básicos é que fizemos os experimentos com a segunda maquete, agora de um trecho de Higienópolis. Esse bairro foi escolhido por apresentar verticalização já consolidada há vários anos, tendo a tipologia da ocupação atual poucas divergências com as plantas cadastrais, escala 1:2000 da EMPLASA, que datam de 1974.

A segunda Maquete abrange três quarteirões do

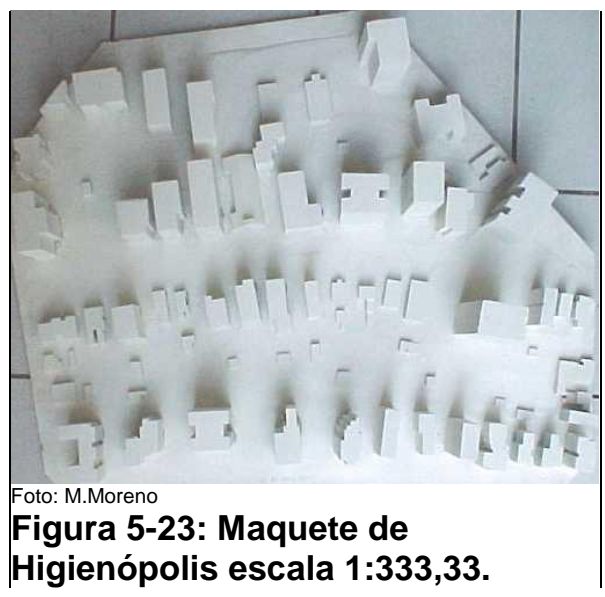


bairro de Higienópolis. Essa área foi definida em função da largura do Túnel, que é de $109 \mathrm{~cm}$ em relação à escala estabelecida de 1:333,33.

A área analisada é delimitada pelas seguintes vias: Av. Angélica, Av. Higienópolis, Rua Maranhão, Rua Piauí, Rua Aracaju e Rua Bahia.

\subsubsection{Semelhança Cinemática dos Escoamentos}

Uma das principais características do Túnel de Vento Atmosférico é reproduzir o perfil das velocidades que ocorrem na realidade, dentro da Camada Limite. Essas velocidades são determinadas pelo grau de rugosidade das superfícies, variando de zero $\mathrm{m} / \mathrm{s}$, junto ao solo, até a velocidade normal que o ar tem quando está fora da influência da rugosidade superficial; em outras palavras, a velocidade que tem fora da camada limite.

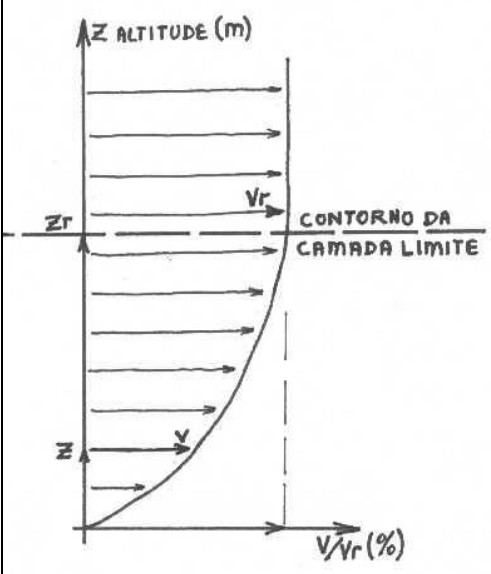

Foto: M.Moreno

Figura 5-24: Perfil de Velocidades.
O expoente $\alpha$ determina a Variação da Velocidade do Vento em função da rugosidade da superfície e todas as fontes bibliográficas apresentam os mesmos valores, respectivamente para cada tipo de superfície.

BLESSMANN ${ }^{88}$ chega a analisar a "Lei de Variação da Velocidade média do Vento com a Altura", o "expoente $\alpha$ " e os "Perfis de Velocidades" fornecidos por 30 fontes diferentes e todos chegam a resultados bastante próximos.

Esses parâmetros se relacionam através da

seguinte equação: $\quad \mathrm{V} / \mathrm{Vr}=(\mathrm{Z} / \mathrm{Zr})^{\alpha}$

onde: $\mathrm{V}=$ Velocidade do Vento na altura considerada

$\mathrm{Vr}=$ Velocidade do Vento fora da Camada Limite

$Z$ = Altitude do Vento considerado

$\mathrm{Zr}=$ espessura da Camada Limite

88 BLESSMANN 1986, op. cit. (p.27 a p.34). 
$\alpha=$ Expoente da Rugosidade

Segundo os cálculos de POPE e RAE ${ }^{89}$, adota-se para cada tipo de superfície:

\begin{tabular}{|l|c|c|}
\hline Tipo de Superfície & Zr (m) & $\alpha$ \\
\hline Campo aberto & 85,3 & 0,15 \\
\hline Edificações baixas & 365,7 & 0,28 \\
\hline Centro Urbano & 518,1 & 0,40 \\
\hline
\end{tabular}

sabendo-se que: $\mathrm{Zr}$ = espessura da Camada Limite e $\alpha=$ Expoente da Rugosidade

Perfil de Velocidades: Esta foi uma etapa muito difícil pois a escolha do tamanho e espaçamento dos obstáculos foi totalmente experimental, isto é, colocavam-se os obstáculos e acionava-se o túnel para mapear as velocidades do ar na área em que seriam feitos os testes com as maquetes, inúmeras vezes, até obter o Perfil de Velocidades relativo aos Centros Urbanos.

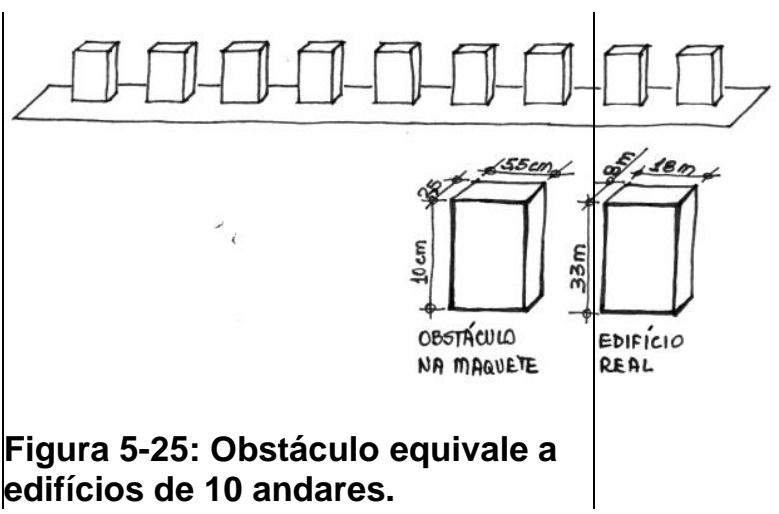

Fizemos os bloquinhos de madeira correspondendo a edifícios com dez andares, altura de 33m na escala 1:333,33. Esses obstáculos, em grupos de nove, foram fixados em lâminas de duratex e estas fixadas no túnel com fita crepe, permitindo flexibilidade na variação dos espaçamentos.

Após inúmeros testes, utilizando catorze conjuntos de obstáculos, espaçados 16 centímetros de eixo a eixo, e mais, a instalação de duas telas e obstáculos triangulares na entrada do túnel, chegamos muito próximo do Perfil de Velocidades que ocorre na realidade.

Planilhas e Gráficos: A medição das velocidades do vento na Câmara de

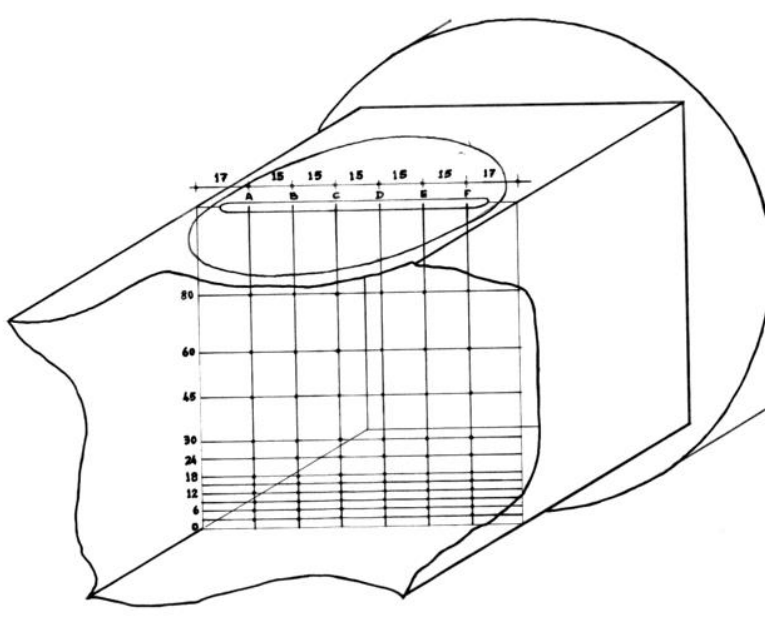

Figura 5-26: Mapa dos pontos de medição das velocidades na Câmara de Testes.

89 POPE e RAE 1984, op. cit. (p.491). 
Testes, seguiu um mapeamento rigoroso, a cada $3 \mathrm{~cm}$ a partir do piso e a cada $15 \mathrm{~cm}$ entre as laterais. As medições foram feitas em um plano transversal sobre o lugar onde seriam colocados os modelos para os testes. Esse procedimento foi anotado em uma planilha criada especificamente para essas medições. A partir dos dados das planilhas, fizemos gráficos que permitiram interpretar os resultados e adotar a configuração mais próxima do perfil de velocidades desejado.
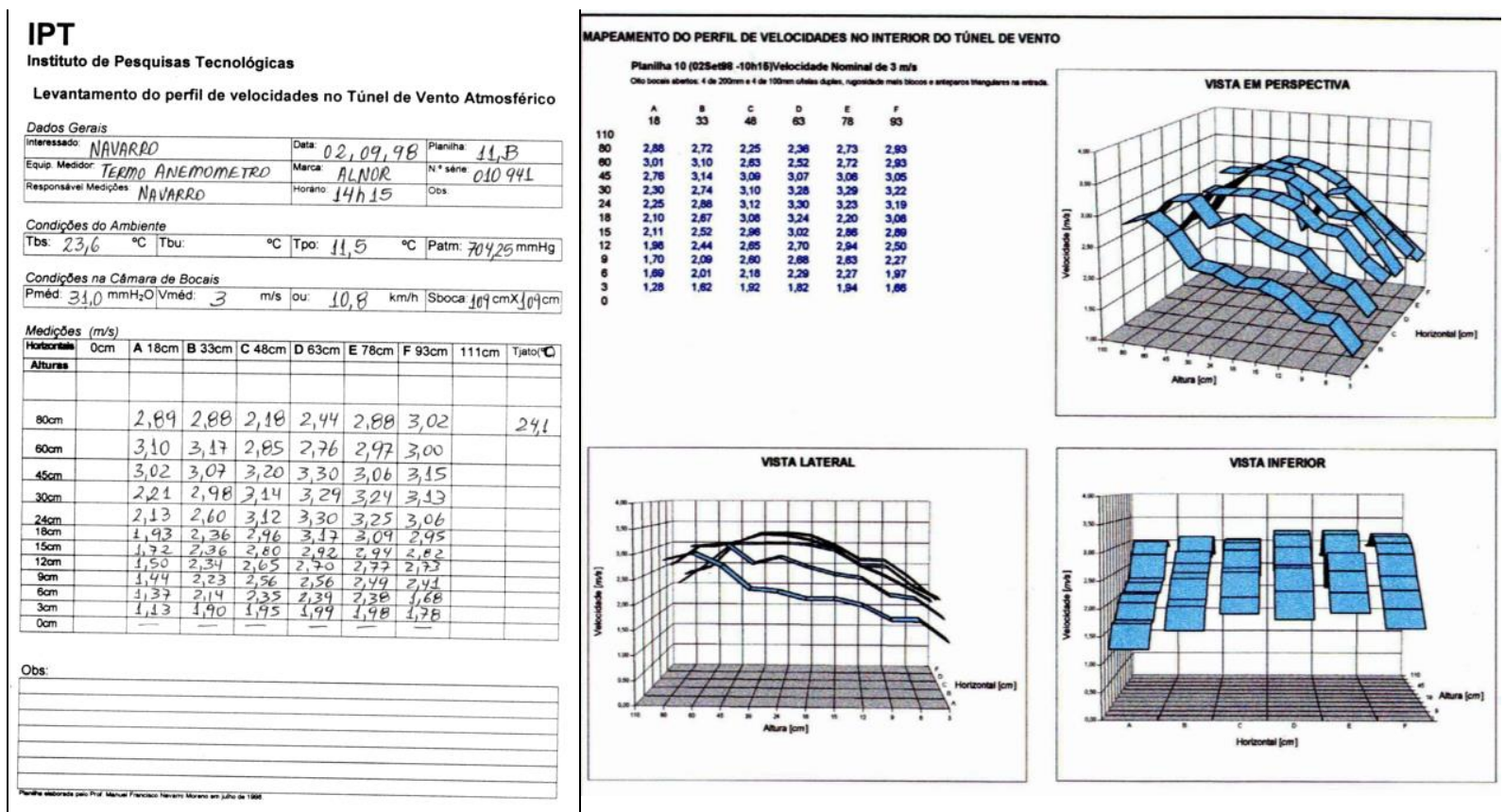

Figura 5-27: Planilha de anotações e Gráficos mostrando o perfil de velocidades.

O Túnel Calibrado: Após os procedimentos citados anteriormente, chegamos a um

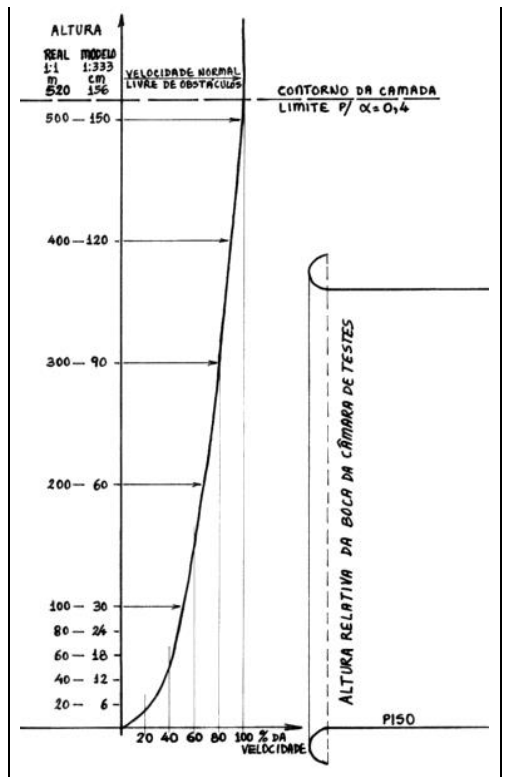

Figura 5-28: Relação entre o perfil de velocidades e a Câmara de Testes para a esc. $1: 333,33$. resultado considerado aceitável, utilizando as rugosidades no piso, os obstáculos triangulares e as telas duplas na entrada, e painéis de madeirit externamente para direcionar a entrada de ar.

O contorno da camada limite, em áreas urbanas verticalizadas, chega a $518 \mathrm{~m}$ de altura, que corresponde, na escala do modelo em estudo $(1: 333,33)$, a $154 \mathrm{~cm}$.

Como nossa Câmara de Testes tem $109 \mathrm{~cm}$ e as edificações mais altas têm no máximo 23 andares, que correspondem a $70 \mathrm{~m}, 21 \mathrm{~cm}$ no modelo, consideramos adequado ajustar o perfil de velocidades para os $60 \mathrm{~cm}$ iniciais acima do piso, que correspondem a $200 \mathrm{~m}$ de 
altura na realidade. Em outras palavras, para o tipo de estudos que estamos fazendo basta que a parte inferior do túnel esteja com o perfil de velocidades adequado, não há necessidade que a altura total da Câmara esteja com as velocidades corretas.

\subsubsection{Semelhança Dinâmica de Forças}

A terceira condição de semelhança é a de constante proporcionalidade entre as forças de pressão, de viscosidade e de inércia, que atuam na realidade e as que agem no modelo. Isso se obtém igualando o $\operatorname{Re}\left(\mathrm{n}^{\circ}\right.$ de Reynolds) nas duas situações. Fizemos os cálculos supondo ventos de $5 \mathrm{~m} / \mathrm{s}$, que na escala de Beaufort é uma Brisa Suave, e encontramos valores altíssimos para a velocidade que teríamos que utilizar no modelo.

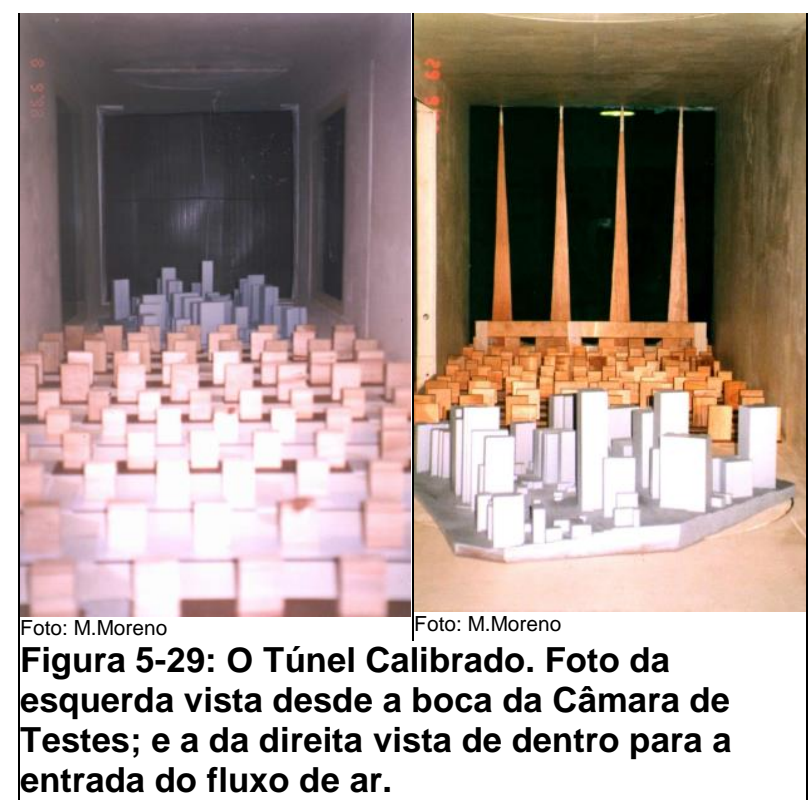

Após várias consultas a especialistas em Mecânica dos Fluidos e a outras referências bibliográficas, concluímos que a igualdade do Re só é necessária quando queremos simular esforços mecânicos, que é o caso do estudo das estruturas.

Para analisar o comportamento dos ventos ao nível dos pedestres, ou mesmo estudar a dispersão de poluentes de escapamentos de automóveis ou de chaminés, trabalha-se com velocidades muito baixas. Segundo ASCE $^{90}$, dependendo do problema que temos em mãos, a velocidade é relativamente arbitrária, por exemplo, no caso de analisar a dispersão de gases, em situações de brisas, as diferenças de temperaturas e perfis de densidades dos fluidos passam a ter importância preponderante, sendo freqüente adotar a mesma velocidade do vento real no Túnel de Vento.

\subsubsection{A Velocidade de Referência}

Os ventos na Cidade de São Paulo, medidos em espaços abertos, na altura de 10 metros, oscilam em média de 2,5 a $5,0 \mathrm{~m} / \mathrm{s}$.

90 ASCE; AEROSPACE DIVISION, op. cit. (p.17 e p.36). 
A escala de BEAUFORT ${ }^{91}$ nos dá parâmetros de referência. Nela poderemos observar que nossos ventos variam entre brisa leve e brisa suave.

Por uma analogia com a velocidade média predominante na Cidade de São Paulo, adotamos nos testes, velocidade de referência $3 \mathrm{~m} / \mathrm{s}$.

\subsubsection{Visualização}

Todo o processo de calibração do Túnel de Vento foi feito sem que pudéssemos ver o comportamento das massas de ar, pois as medições foram feitas com termoanemômetros, e esse tipo de equipamento fornece dados quantitativos. Numa etapa posterior, com a elaboração dos gráficos dos perfis de velocidades é que pudemos ter uma idéia qualitativa do que estava ocorrendo.

\subsubsection{Gerador de Fumaça}

No dia 09 de setembro de 1998, já utilizando a Maquete 1:333, experimentamos visualizar o comportamento do vento ao redor dos edifícios, usando um Gerador de Fumaça. Em velocidades normais de 3 ou $5 \mathrm{~m} / \mathrm{s}$, a dispersão da fumaça é muito rápida e praticamente não se vê nada.

\begin{tabular}{|c|c|c|c|c|}
\hline $\begin{array}{l}\text { Número } \\
\text { Beaufort }\end{array}$ & $\begin{array}{l}\text { Descrição } \\
\text { do Vento }\end{array}$ & $\begin{array}{c}\begin{array}{c}\text { Velocidade } \\
(\mathrm{m} / \mathrm{s})\end{array} \\
\end{array}$ & $\begin{array}{c}\text { Velocidade } \\
(\mathrm{km} / \mathrm{h})\end{array}$ & Descrição dos efeitos do Vento \\
\hline 0 & calmaria & menos 0,4 & menos 1,4 & Calmo; fumaça eleva-se verticalmente. \\
\hline 1 & $\begin{array}{l}\text { aragem } \\
\text { leve }\end{array}$ & 0,4 a 1,5 & 1,4 a 5,4 & $\begin{array}{l}\text { direção do vento mostrada por inclinação de } \\
\text { fumaça, mas não por cata-vento. }\end{array}$ \\
\hline 2 & brisa leve & 1,6 a 3,3 & 5,5 a 12 & $\begin{array}{l}\text { vento sentido no rosto; folhas das árvores } \\
\text { agitadas. }\end{array}$ \\
\hline 3 & brisa suave & 3,4 a 5,4 & 12 a 19 & $\begin{array}{l}\text { cabelos desarrumados; vento desfralda bandeira } \\
\text { leve. }\end{array}$ \\
\hline 4 & $\begin{array}{l}\text { vento } \\
\text { moderado }\end{array}$ & 5,5 a 7,9 & 19 a 26 & $\begin{array}{l}\text { vento levanta poeira; papéis soltos; pequenos } \\
\text { galhos são movidos. }\end{array}$ \\
\hline 5 & $\begin{array}{l}\text { vento } \\
\text { fresco }\end{array}$ & 7,9 a 10,7 & 26 a 35 & $\begin{array}{l}\text { força dos ventos sentida no corpo; pequenas } \\
\text { árvores são sacudidas; formam-se pequenas } \\
\text { ondas nos lagos. }\end{array}$ \\
\hline 6 & vento forte & 10,7 a 12,2 & 35 a 44 & $\begin{array}{l}\text { uso de sombrinhas com dificuldade; cabelos } \\
\text { golpeados imediatamente; dificuldade de } \\
\text { caminhar com firmeza; vento assobia nos fios; } \\
\text { desagradável no ouvido. }\end{array}$ \\
\hline 7 & $\begin{array}{l}\text { tempestade } \\
\text { moderada }\end{array}$ & 12,2 a 15,2 & 44 a 55 & $\begin{array}{l}\text { grandes árvores sacudidas; inconveniência } \\
\text { sentida quando se caminha contra o vento. }\end{array}$ \\
\hline 8 & tempestade & 15,2 a 18,5 & 55 a 66 & $\begin{array}{l}\text { ramos de árvores quebrados; geralmente impede } \\
\text { de caminhar na rua. }\end{array}$ \\
\hline 9 & $\begin{array}{l}\text { tempestade } \\
\text { forte }\end{array}$ & 18,5 a 21,6 & 66 a 78 & leves danos estruturais; telhas arrancadas. \\
\hline 10 & $\begin{array}{l}\text { tempestade } \\
\text { total }\end{array}$ & acima 21,6 & acima 78 & $\begin{array}{l}\text { árvores arrancadas; consideráveis danos } \\
\text { estruturais }\end{array}$ \\
\hline
\end{tabular}

91 FORSDYKE, A. G. - Previsão do Tempo e Clima, São Paulo, Melhoramentos- Edusp, 1975.(p.30). 
Fomos reduzindo a velocidade do vento gradativamente, a $1 \mathrm{~m} / \mathrm{s}$ por alguns instantes podiam-se perceber algumas trajetórias, mas nada suficientemente estável que permitisse documentar fotograficamente. Filmamos a experiência e embora já tenhamos estudado o filme, não nos parece que contenha informações significativas que valham a pena digitalizar para substanciar alguma conclusão.

Experimentamos reduzir mais ainda a velocidade do ar, até próximo de $0,5 \mathrm{~m} / \mathrm{s}$, também não pareceu significativo. Cremos que a fumaça saia, do gerador de fumaça, em jatos mais rápidos que o ar analisado, e portanto, talvez tivéssemos informações dos jatos de fumaça, mas não do vento em estudo. Além do que, velocidades tão baixas praticamente correspondem à movimentação normal do ar nos recintos, sendo muito grandes as possibilidades de distorções nas direções dos ventos em estudo.

\subsubsection{A Visita do Dr. Jorge Saraiva}

Na segunda semana de setembro de 1998, soubemos da vinda ao Brasil, para proferir palestra na FAU USP, do Dr. Jorge Alberto Gil Saraiva, Investigador Coordenador do Núcleo de Dinâmica Aplicada do LNEC (Laboratório Nacional de Engenharia Civil). Estabelecemos contato e o Dr Saraiva concordou em nos visitar. No dia 16 de setembro de 1998 compareceu ao IPT para opinar sobre nossas experiências.

Os subsídios advindos dessa visita, são os seguintes: a) Os Túneis de Vento Atmosféricos podem ser curtos, ao contrário do que consta na bibliografia conservadora tradicional que recomenda proporções comprimento/largura da ordem de 10 a 15/1. Para tanto, é necessário que, ao invés de usar uma grande superfície para simular a rugosidade urbana, pode-se utilizar, por exemplo, uma série de barras paralelas horizontais, convenientemente espaçadas na entrada do Túnel. b) Para visualizar o comportamento do vento ao nível dos pedestres, tem-se usado no LNEC, areia (técnica da saltação de grãos) ${ }^{92}$, a exemplo dos recentes estudos, em Túnel de Vento, das áreas livres da Expo 98 em Lisboa.

\footnotetext{
92 BORGES, A.R. Janeiro e SARAIVA, Jorge A.G.(@1979) - An Erosion Technique for Assessing Ground Level Winds, Fort Collins, 5th International Conference on Wind Engenering, Colorado State University, 1979. (memória 565, Lisboa, LNEC, 1981)
} 


\subsubsection{Usando Areia - Princípio da Saltação de Owen}

A sugestão de usar areia, muito nos entusiasmou, pois nos remeteu aos testes que fazíamos a um quarto de século atrás com as bolinhas de isopor. É praticamente a mesma técnica, mudando somente a densidade das partículas.

O processo consiste em distribuir uma camada fina e uniforme de areia sobre 0 modelo e analisar os fluxos de ar junto às superfícies horizontais, à medida que se aumenta a velocidade dos ventos.

Seguindo as indicações do Dr. Jorge Saraiva e de $\mathrm{OWEN}^{93}$, iniciamos os testes utilizando areia com granulometria $0,4 \mathrm{~mm}$. Como as velocidades para obter resultados eram muito altas, acima de $5 \mathrm{~m} / \mathrm{s}$, experimentamos usar granulometrias $0,3 \mathrm{~mm}$ e menores, adotando $0,15 \mathrm{~mm}$ como a mais adequada.

Com a areia de $0,15 \mathrm{~mm}$ as primeiras saltações ocorriam com ventos de $2,5 \mathrm{~m} / \mathrm{s}$, chegando à eliminação da maior parte da areia aos $6 \mathrm{~m} / \mathrm{s}$. Convém lembrar que a velocidade máxima na Câmara de Testes, que inicialmente excedia $10 \mathrm{~m} / \mathrm{s}$, foi sendo drasticamente reduzida com a instalação das telas e dos tecidos para reter a areia; aliás, à medida que o tecido fica impregnado de areia, diminui a vazão e a velocidade máxima do Túnel.

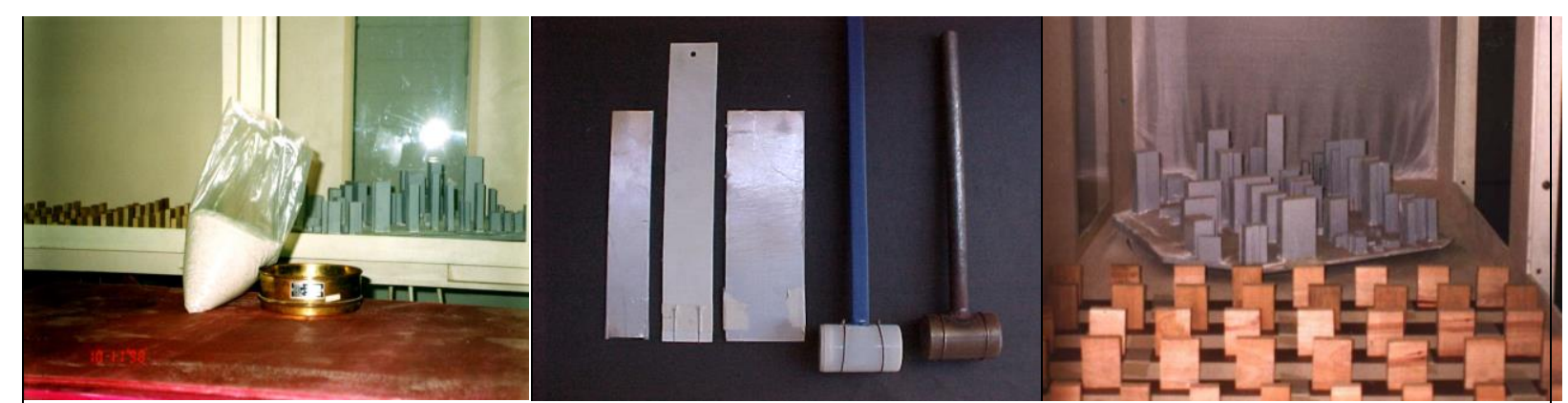

Figura 5-30: Areia 0,15mm; Instrumentos desenvolvidos para espalhar uniformemente; e Teste.

\subsubsection{Descrição dos Testes Realizados}

Praticamente todas as publicações que tratam do assunto da Ventilação na Arquitetura, utilizadas nas escolas de arquitetura brasileiras, reproduzem os estudos clássicos, pioneiros, de experimentos em Túneis de Vento, realizados no Centro de Engenharia Experimental do Texas, por Benjamin H. EVANS ${ }^{94}$ e no Centro de Investigação Florestal da Universidade de Princeton, realizados por Victor

\footnotetext{
93 OWEN, P.R. - Saltation of Uniform Grains in Air, in J.Fluid Mech, vol20, part 2, pp225-242, London, 1964.

94 EVANS, Benjamin H. - Natural Air flow AroundBuildings, College Station, Texas Engineering Experiment Station, 1957.
} 
OLGYAY ${ }^{95}$. Embora sejam estudos valiosíssimos, predominantemente estão restritos a análises do vento no interior das habitações e no entorno de edificações com diversos formatos e tipos de telhados, porém, isolados, não chegam a estudar os ventos em tecidos urbanos verticalizados.

Observando o comportamento do vento sobre a fina camada de areia espalhada sobre as superfícies das maquetes, podemos deduzir suas trajetórias, áreas em que o ar se acelera e locais em que a velocidade diminui ou até chega a estagnar. Considerando-se que tivemos o cuidado de atender às três semelhanças fundamentais, em dias com vento, as ocorrências observadas no Túnel deverão se confirmar.

\subsubsection{Adquirindo Sensibilidade para Interpretar os Testes}

Antes de iniciar os testes com as maquetes de trechos urbanos verticalizados, fizemos vários experimentos com modelos simplificados para perceber e interpretar os comportamentos do vento.

Como descrito no item "Construção de Modelos 1:333,33" construímos três maquetes com implantações básicas para adquirir conhecimentos genéricos que possam subsidiar a interpretação dos testes com as maquetes de trechos urbanos.

A seqüência de procedimentos consistiu em:

a) Posicionar a maquete no ângulo adequado de incidência dos ventos; em geral, foram feitos experimentos, com incidência perpendicular, com incidência de $30^{\circ}$ para a direita e de $30^{\circ}$ para a esquerda;

b) Distribuir uma camada uniforme de areia, com granulometria $0,15 \mathrm{~mm}$. Para tanto, desenvolvemos vários tipos de espátulas, até chegarmos a desenvolver um cilíndrico espalhador, que nos permitiu obter uma camada de areia uniforme com $0,4 \mathrm{~mm}$ de espessura;

c) Utilizando o variador de potência, ligado na entrada de energia do motor do túnel de vento, graduávamos o vento; observando, filmando e fotografando o deslocamento da areia, à medida que a velocidade do ar aumentava.

95 OLGYAY, Victor (@1963 Design with Climate) - Arquitectura y Clima, Barcelona, Gustavo Gili, 1998. (pp.94-112) 
d) Verificávamos que os locais onde a areia era removida, indicavam maiores velocidades do vento. Nos lugares onde ela se acumulava, os ventos eram mais lentos, indicando acúmulos de poeira e/ou poluição.

\subsubsection{Edifício Obstruído por Outro Igual}

Este experimento mostrou que nos dias com vento, ocorre intensa aceleração do ar nos cantos dos prédios (efeito canto), o que inviabilizará a utilização dessas áreas livres no inverno em virtude do ar frio. Se esses edifícios estiverem em região com muita poeira e fumaça no ar, esses materiais, deslocando-se em velocidade, também causarão desconforto, mesmo em outras estações do ano.

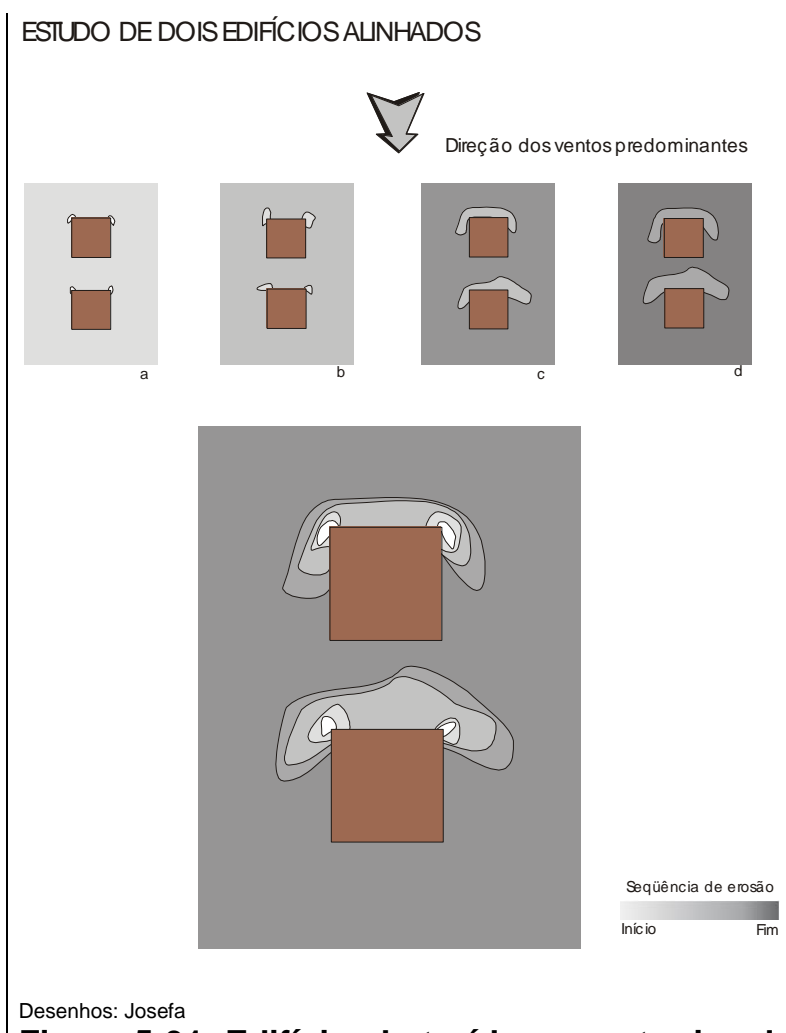

Figura 5-31: Edifício obstruído por outro igual
Nas áreas em que houve o acúmulo de areia, constatamos ventos mais lentos ou ar parado e, portanto, são áreas em que ocorrerão acúmulos de poeira, isto é, na realidade deve ocorrer a mesma coisa, acúmulo de poluição; principalmente materiais particulados.

Quanto ao topo dos edifícios, nota-se maior acúmulo de areia na frente do primeiro prédio, indicando que o vento sobe pela borda frontal, enquanto no segundo a areia é removida na frente, indicando que nessa parte os ventos são mais velozes que no restante da cobertura. 
5.3.9.2 Agrupamento de Edifícios Iguais Alinhados

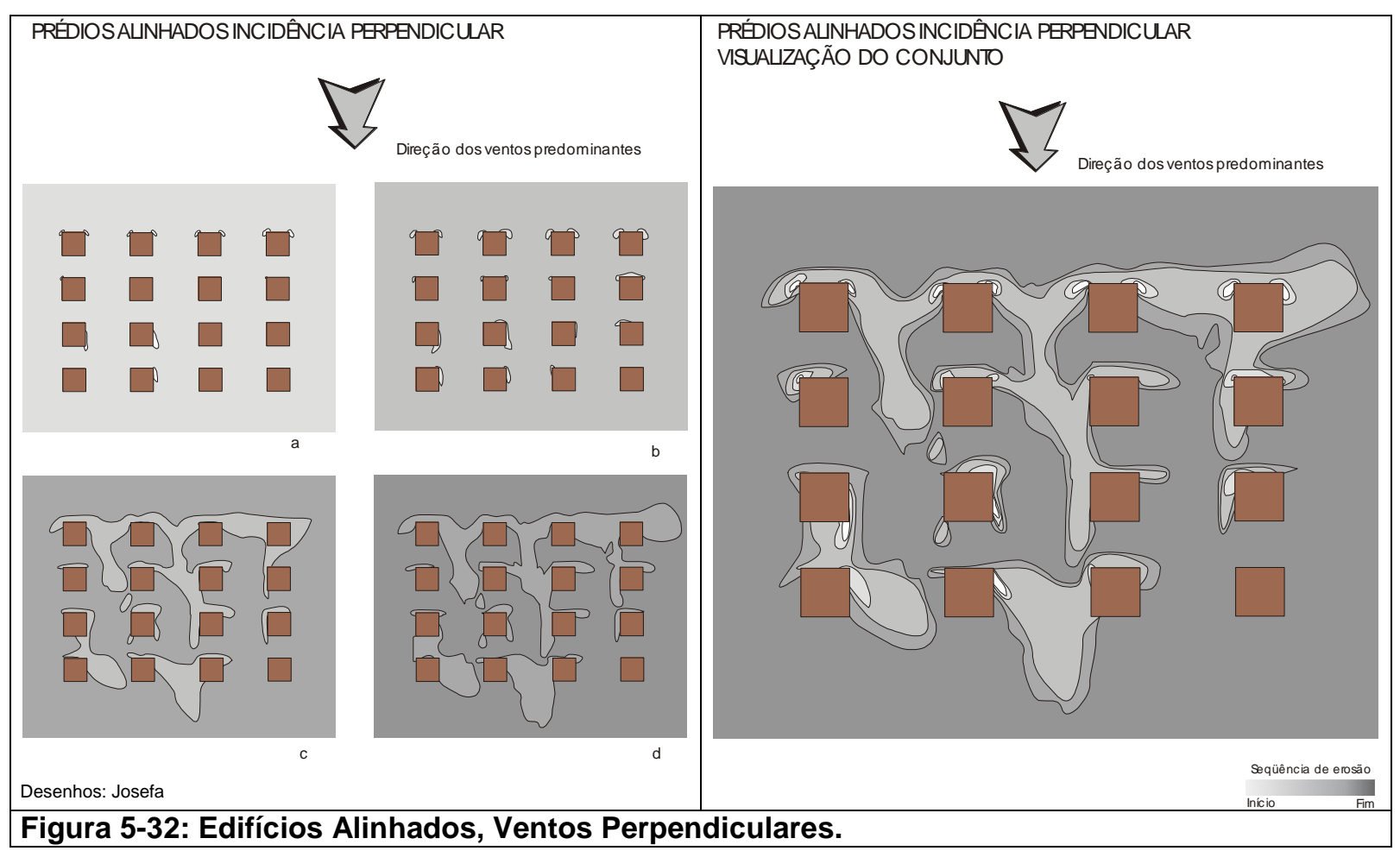

Os testes realizados com edificações alinhadas, com incidência perpendicular dos ventos, mostram o efeito de mascaramento, no qual os primeiros prédios obstruem ou reduzem a ventilação nos outros que estão logo atrás. O mascaramento é tanto maior quanto mais lentos forem os ventos.

Também é significativa a aceleração do ar na direção dos corredores formados pelos edifícios, cuja ocorrência é conhecida como efeito desfiladeiro.

O acúmulo de areia, logo atrás das construções, indica ocorrência semelhante na realidade, com acúmulo de poluentes e material particulado atrás das edificações reais. 


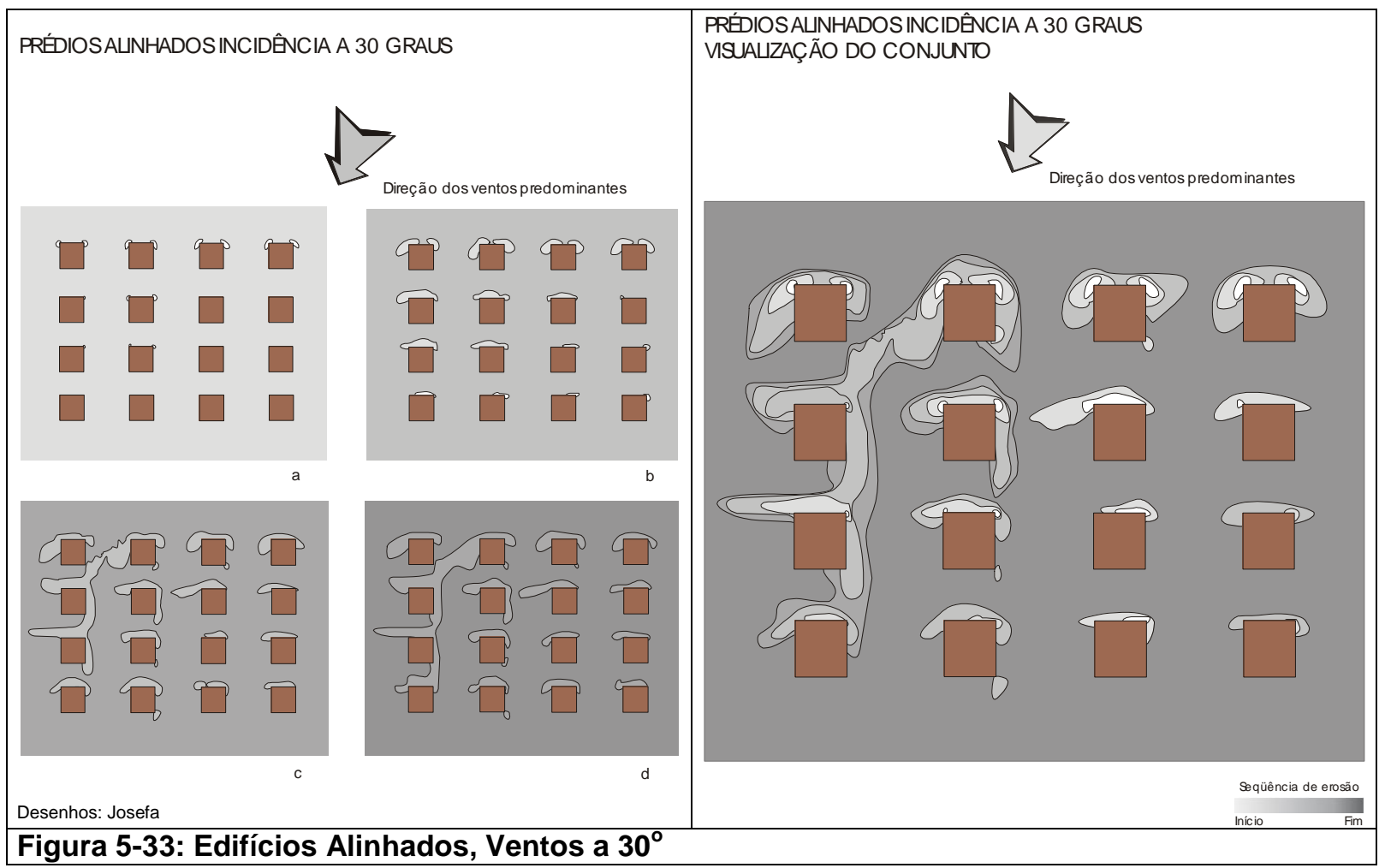

Também fizemos testes com o vento incidindo inclinado a 30․ O resultado mostrou que $o$ efeito desfiladeiro praticamente inexiste. Quanto ao mascaramento, nota-se que agora é bem menor.

Com o vento incidindo a $60^{\circ}$, o mascaramento inexiste, isto é, as construções não obstruem os ventos nas outras edificações.

Os resultados foram parecidos com o que obtivemos com a disposição desencontrada, onde praticamente não há efeito desfiladeiro. 
Procedimentos e Instrumental de Análise

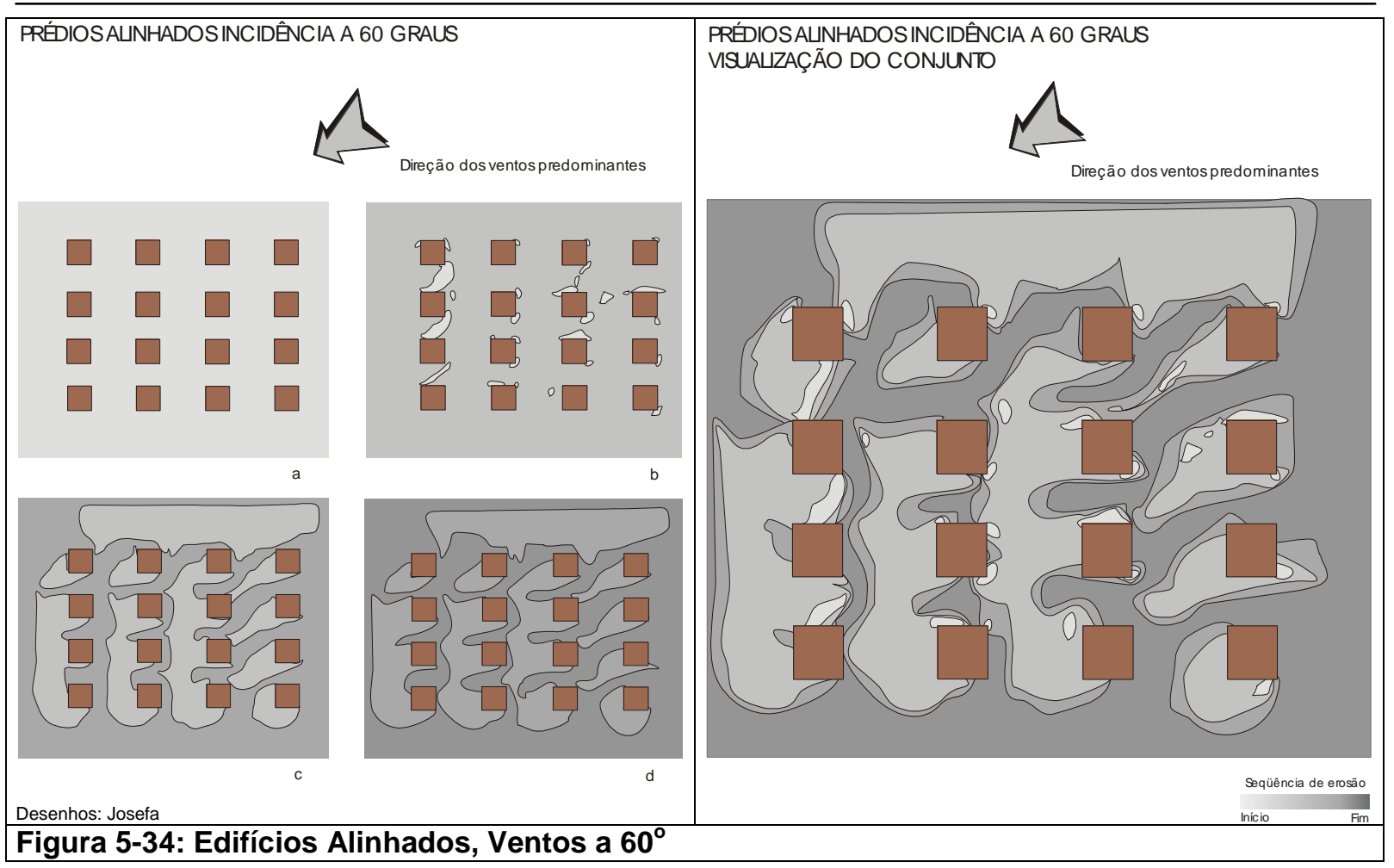

5.3.9.3 Agrupamento de Edifícios Iguais Desencontrados

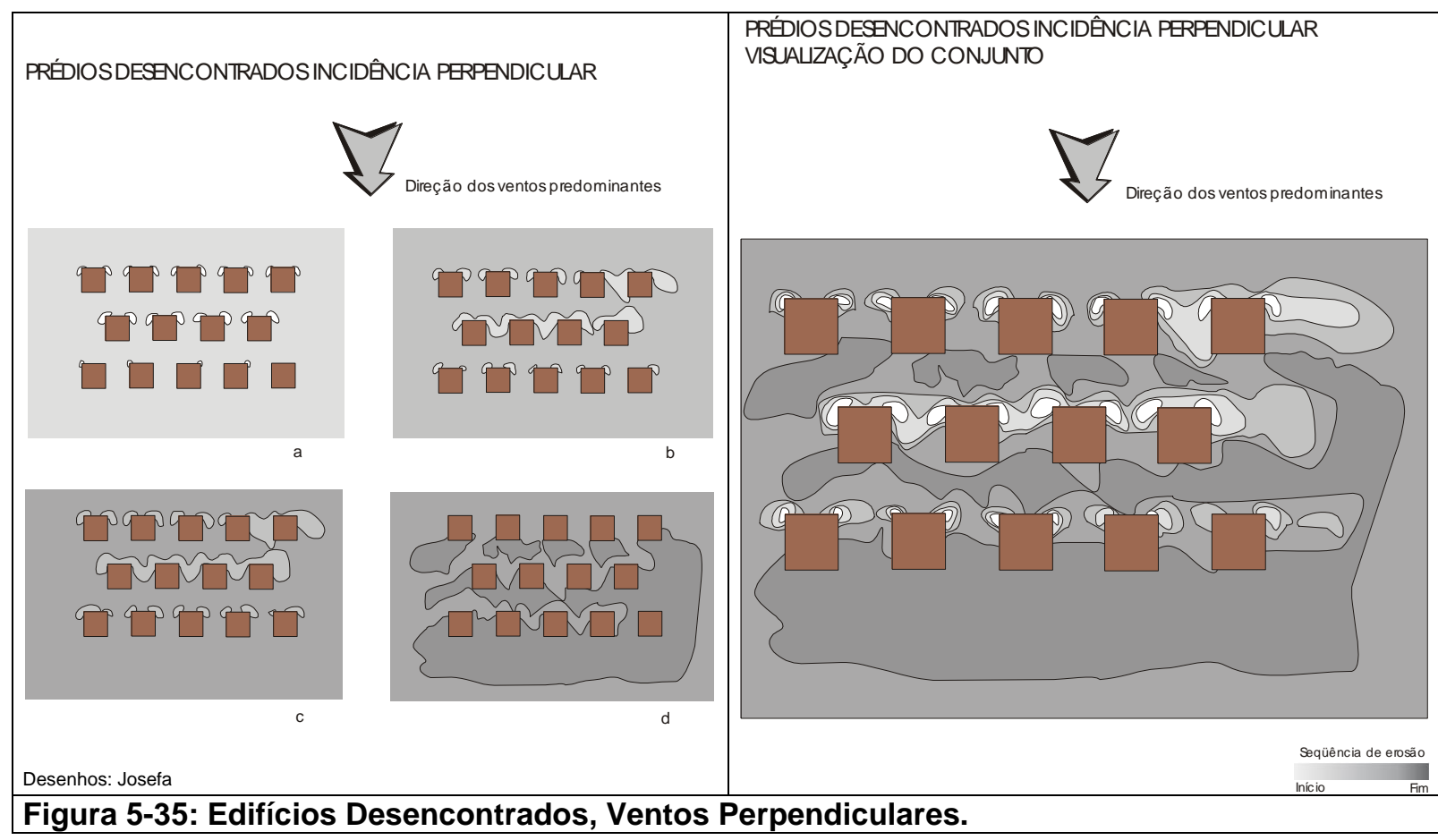

O experimento com edificações desencontradas mostra que praticamente todas as construções recebem ventilação como se fossem as primeiras. Não se observou a formação de ventos encanados pelo efeito desfiladeiro.

Os testes com ventos incidindo a $30^{\circ}$ também se mostraram eficientes, sem o efeito de mascaramento e nem tampouco os ventos encanados pelo efeito desfiladeiro. 


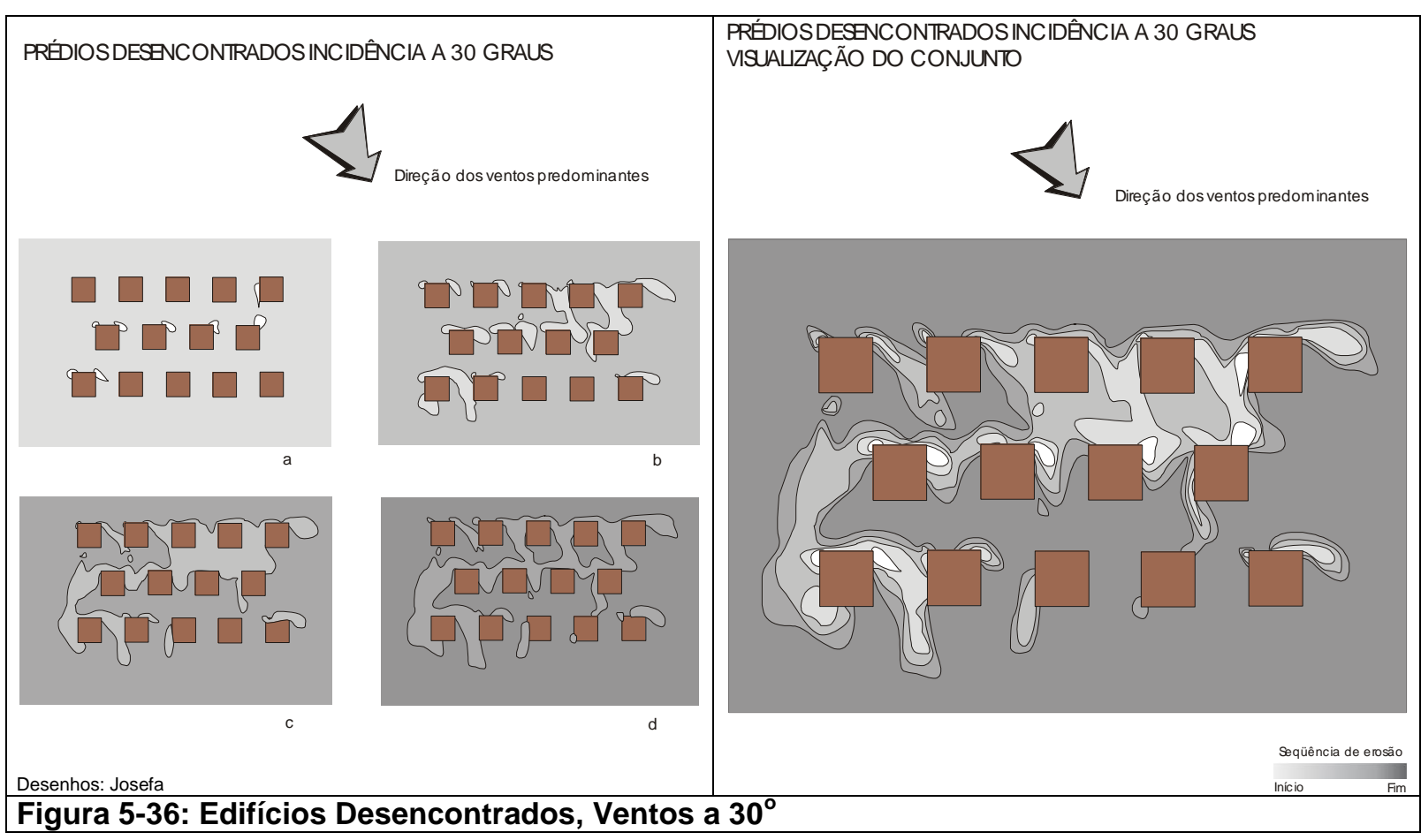

\subsubsection{Testes com a Maquete da Área de Higienópolis}

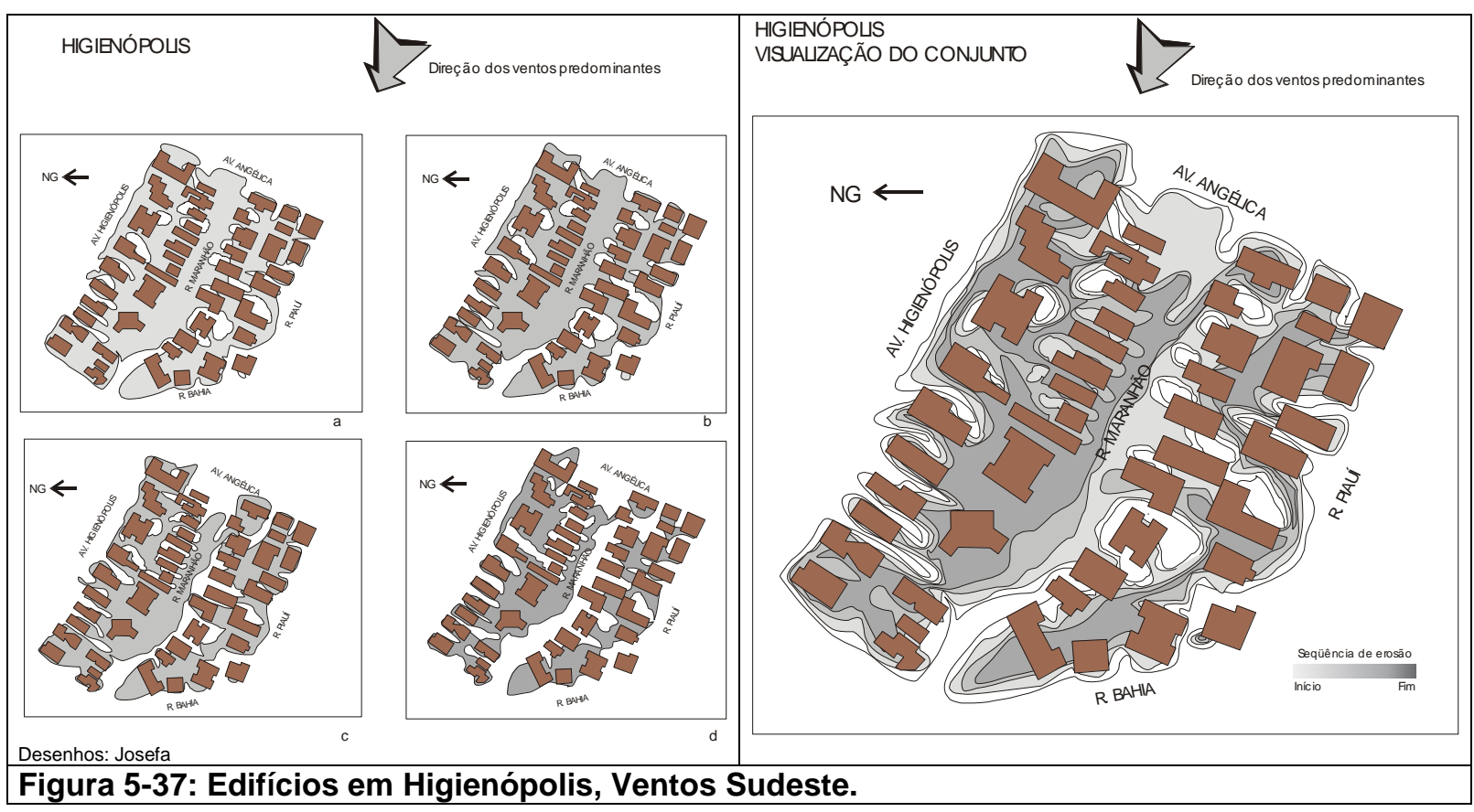

Assim como nos testes anteriores, a Câmara de Testes dispunha: a) obstáculos simulando a rugosidade urbana; b) triângulos para acentuar o perfil de velocidades; c) telas duplas na entrada para equalizar os ventos ; e d) tecidos duplos na saída da Câmara de Testes para evitar que a areia passasse para a Câmara de Bocais. 
A maquete foi posicionada com os ventos fluindo de Sudeste, que são os predominantes e coincidem com a direção da rua Maranhão, ou seja, os ventos fluem pela rua Maranhão, da Avenida Angélica para a rua Bahia.

Com ventos a $3 \mathrm{~m} / \mathrm{s}$, podemos notar que o vento se acelera pela subida da topografia e pelo efeito desfiladeiro provocado pelos grandes edifícios na rua Maranhão próximo à rua Bahia, área clara à direita. Nessa área, o vento incomodará, no inverno, por ser frio e nas outras estações do ano, por conter fumaça, poeiras, folhas e papéis, que podem, além de incomodar, impregnar os transeuntes com essas sujeiras.

Notam-se grandes áreas onde há acúmulo de areia, indicando concentração de poluição e materiais particulados nas áreas mais escuras da figura.

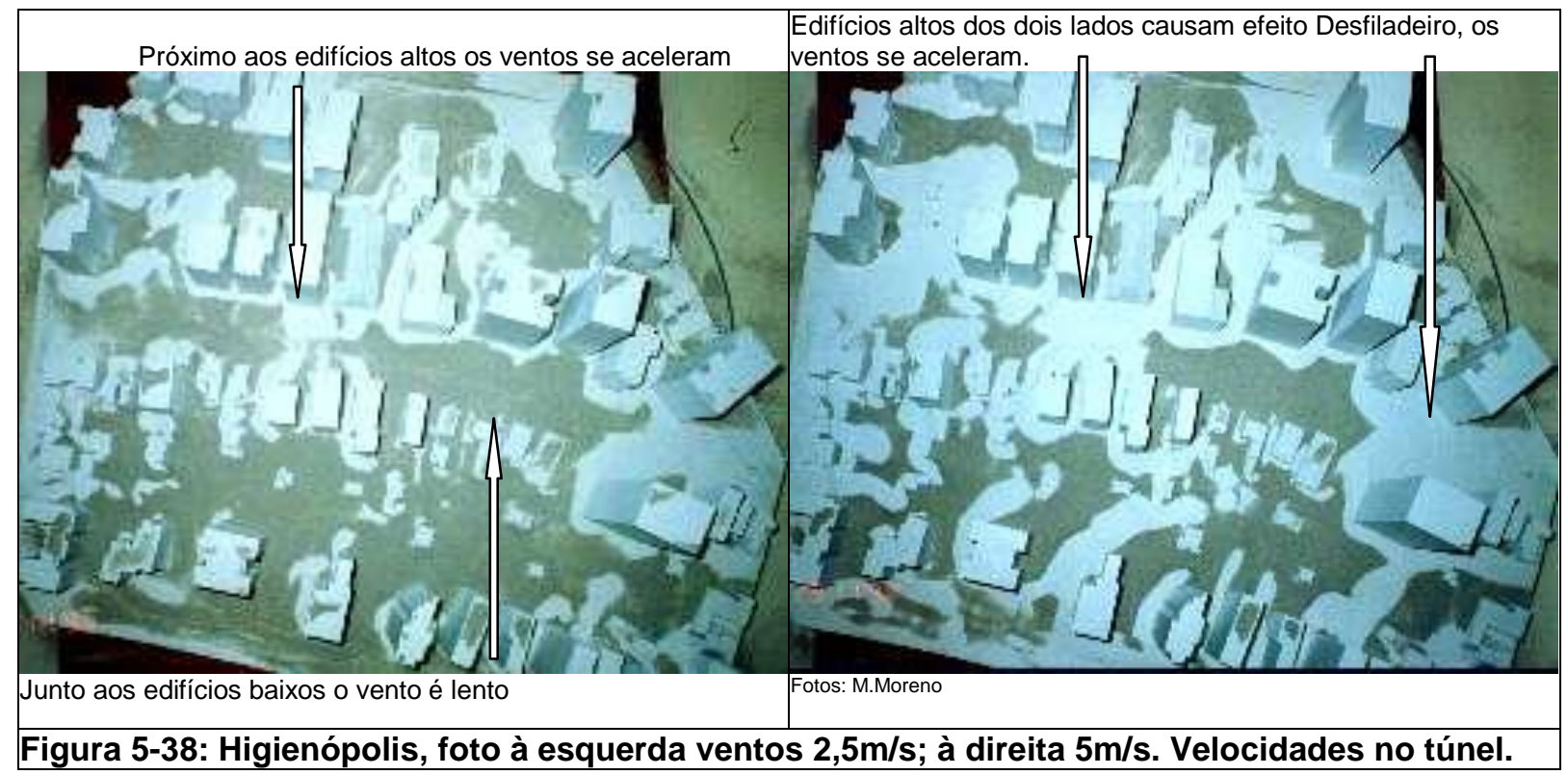

O comportamento da areia sob ação dos ventos a $5 \mathrm{~m} / \mathrm{s}$; a nosso ver, é uma imagem extremamente didática. No trecho em que temos edificações altas de ambos os lados da rua, cria-se o efeito desfiladeiro; o vento se acelera e remove a areia. $\mathrm{Na}$ parte da rua, em que há prédios altos de um lado e baixos do outro, nota-se uma estagnação da areia, significando que os ventos estão mais lentos. É interessante observar que junto às construções altas, o ar corre rápido, pois a areia foi removida.

Esta experiência também mostra, nas áreas livres no interior das quadras, locais de acúmulo de areia, indicando concentração de poluentes e poeiras, e regiões onde a areia foi retirada e, portanto, os ventos estão mais rápidos, podendo trazer partículas incômodas ou acentuar a sensação de frio no inverno. 


\subsubsection{Considerações Finais}

A cada dia surgem aprimoramentos nos softwares que simulam o comportamento dos ambientes em relação às variáveis que interferem na habitabilidade, inclusive nos aspectos da ventilação. Nos últimos anos, temos procurado programas que simulem o comportamento dos ventos ao nível dos pedestres e que forneçam dados sobre o conforto térmico e a poluição. Os poucos softwares, dos quais temos tido informações, não simulam a enorme complexidade dos espaços urbanos, limitandose a trabalhar com ambientes internos.

Por exemplo, o professor do Curso de Arquitetura e Urbanismo da Universidade Federal de Alagoas, Leonardo Salazar BITTENCOURT ${ }^{96}$ apresentou no Encontro Nacional de Modelos de Simulação de Ambientes, realizado em setembro de 1995 na FAUUSP, dois programas que simulam a ventilação natural, o Breeze e 0 Easyflow. Como conclusão de seu artigo, BITTENCOURT comenta que: a) o Breeze determina a taxa de renovações do ar de edifícios; é mais adequado onde aspectos quantitativos da ventilação são mais relevantes; b) o Easyflow mostra graficamente a intensidade e distribuição do fluxo de ar no interior de ambientes, solucionando os problemas qualitativos da ventilação.

Até o momento, acreditamos que a simulação física tridimensional, dos ventos incidindo em trechos urbanos verticalizados, viabilizada por Túneis de Vento Atmosféricos, é mais próxima da realidade e mais adequada para lidar com inúmeros parâmetros geométricos e físicos, envolvidos no estudo dos ventos, interagindo com a poluição e sobre as pessoas nos espaços livres em torno de grandes edificações.

\footnotetext{
96 BITTENCOURT, Leonardo S. - Comparando os Programas Breeze e Easyflow como Instrumentos de Simulação da VentilaçãoNatural, in Encontro nacional de modelos de simulação de ambientes, (pp.177-188), São Paulo, NUTAU, FAUUSP, 1995.
} 



\section{Conclusões}

Neste trabalho mostramos que:

As conseqüências das intervenções arquitetônicas e urbanísticas sobre o meio ambiente manifestam-se, quanto ao tempo e ao espaço, em duas instâncias: a) na macro-escala metropolitana, pelo conjunto de milhares de intervenções ao longo de décadas; e b) na escala da vizinhança, no curto prazo da materialização de cada intervenção.

O profissional tem que assumir suas responsabilidades em relação à qualidade do ambiente que ajuda a produzir. Mesmo na escala metropolitana, deve se preparar melhor e participar da elaboração das diretrizes de gestão urbana e ambiental. Na escala da vizinhança é imperativo que conheça, domine e aplique os conhecimentos de qualidade ambiental.

Para tanto, o Arquiteto e Urbanista deve agregar à sua formação multidisciplinar, mais conhecimentos sobre as implicações de sua atuação profissional no meio natural e no meio urbano.

Intuição: O processo de elaboração dos projetos arquitetônicos e urbanísticos geralmente tem mais de criação sensível do que de decisões racionais. A criação é mais intuitiva do que lógica. Os conhecimentos sobre as relações do ambiente com as intervenções arquitetônicas ou urbanísticas, terão mais chances de serem melhor aplicados se forem trazidos do plano racional para o intuitivo.

$\mathrm{Na}$ rotina da elaboração do projeto na prática profissional não há tempo (ou é complexo) para assimilar os conhecimentos necessários naquele instante. A gênese de vários problemas ambientais está no momento do projeto, quando muitos fenômenos são desconhecidos ou ignorados pelo profissional.

Desde a fase de formação do aluno de Arquitetura e Urbanismo e depois no aprimoramento constante do profissional, deve-se assimilar os conhecimentos fazendo-os passar pela lógica e trazendo-os até o nível da intuição através de situações que permitam vivenciar os fenômenos ambientais.

Instrumental: A vivência é a melhor escola. Podemos ter uma idéia de algo que ouvimos falar, mas a experiência de participar de um evento fica indelével na mente. 
O barateamento da eletrônica permite que os profissionais tenham acesso a sofisticados instrumentos de medida por custos viáveis. Além disso, vários equipamentos podem ser construídos, tal sua simplicidade. $\mathrm{O}$ importante é que o estudante ou o Arquiteto ao sair a campo, para medir e constatar fenômenos ou ao colocar uma maquete ao Sol para estudos de insolação, está fazendo, está incorporando, está assimilando esses fenômenos.

Quando não for possível comprovar os fenômenos na realidade, as simulações com modelos físicos, como maquetes, podem reproduzir os fenômenos com razoável grau de precisão, sendo instrumentos preciosos no desenvolvimento da intuição.

Os levantamentos e análises realizados durante a fase de pesquisa de dados, comprovaram o grau de precisão dos modelos, por exemplo, tanto no uso de maquetes ao Sol para estudos de insolação, quanto no uso de modelos em túnel de vento.

Síntese: Como síntese, apresenta-se um quadro que mostra uma análise crítica dos problemas de qualidade ambiental nos espaços livres em áreas verticalizadas, organizados quanto ao envolvimento e grau de resposta do Arquiteto e Urbanista, em duas instâncias:

a) Gestão Urbana, que retoma a evolução urbana no longo prazo, com as alterações ambientais causadas pelo conjunto da infinidade de intervenções pontuais; que implicam em modificações climáticas, energéticas, geomorfológicas e hidrológicas. Urgem por recomendações, normas e legislações, alicerçadas em uma visão dos fenômenos mais abrangentes no tempo e no espaço, que norteiem a evolução ambiental das metrópoles, a conscientização da sociedade e a sua qualidade de vida;

b) Projetual, que ressalta a responsabilidade do profissional no momento da elaboração do projeto, lembrando que cada intervenção física de Arquitetura e Urbanismo trazem implicações em seu entorno próximo, de imediato, no momento de sua materialização, que requerem profissionais conscientes e intuitivos preparados para contribuir no aprimoramento do habitat humano. Que implica em aperfeiçoar as instâncias que moldam esses profissionais, como sua formação acadêmica e o tipo de trabalho que a sociedade lhe solicita. 


\begin{tabular}{|c|c|c|}
\hline $\begin{array}{l}\text { Aspecto da Qualidade } \\
\text { Ambiental }\end{array}$ & $\begin{array}{l}\text { Gestão Urbana: } \\
\text { normas, leis, administração } \\
\text { pública }\end{array}$ & $\begin{array}{c}\text { Projetual: } \\
\text { criação e gerenciamento de } \\
\text { obras arquitetônicas e } \\
\text { urbanísticas } \\
\end{array}$ \\
\hline Fontes de Energia & $\begin{array}{l}\text { Reduzir os gastos energéticos, } \\
\text { pensando o fluxo energético na } \\
\text { metrópole: zoneamento que } \\
\text { reduza os deslocamentos; que } \\
\text { permita aproveitar melhor as } \\
\text { energias naturais; ... . }\end{array}$ & $\begin{array}{l}\text { Eliminar o desperdício } \\
\text { energético, usando Fontes que } \\
\text { gerem o tipo de energia } \\
\text { efetivamente necessária para } \\
\text { cada uso. }\end{array}$ \\
\hline Formas de Relevo, Bacias & $\begin{array}{l}\text { Adotar a bacia hidrográfica, ou } \\
\text { cada sub-bacia como unidade } \\
\text { de gestão e urbanização. }\end{array}$ & $\begin{array}{l}\text { Pensar cada intervenção como } \\
\text { parte da bacia hidrográfica. }\end{array}$ \\
\hline Drenagem e Permeabilidade & $\begin{array}{l}\text { Gerir a metrópole viabilizando a } \\
\text { preservação do ciclo hidrológico } \\
\text { natural. }\end{array}$ & $\begin{array}{l}\text { Prever sistemas de retenção, } \\
\text { que façam com que as águas } \\
\text { pluviais fluam na velocidade que } \\
\text { tinham antes das construções. }\end{array}$ \\
\hline Áreas de Risco & $\begin{array}{l}\text { Determinar usos adequados } \\
\text { para as várzeas e as encostas } \\
\text { de maiores declividades. }\end{array}$ & $\begin{array}{l}\text { Intervir respeitando, mantendo } \\
\text { ou controlando os ciclos naturais } \\
\text { das cheias e deslizamentos. }\end{array}$ \\
\hline Corpos D'água & $\begin{array}{l}\text { Administrar a implantação de } \\
\text { represas, lembrando que } \\
\text { alteram o clima. }\end{array}$ & Considerar as influências locais. \\
\hline Iluminação & $\begin{array}{l}\text { Viabilizar o adequado } \\
\text { aproveitamento dos } \\
\text { aclaramentos em cada parcela. }\end{array}$ & $\begin{array}{l}\text { Usar prioritariamente as } \\
\text { iluminâncias naturais. }\end{array}$ \\
\hline Ruídos & $\begin{array}{l}\text { Desenvolver equipamentos e } \\
\text { sistemas silenciosos; } \\
\text { regulamentar um zoneamento } \\
\text { acústico. }\end{array}$ & $\begin{array}{l}\text { Não usar, direta ou } \\
\text { indiretamente, fontes ruidosas. }\end{array}$ \\
\hline Odores & Impedir as fontes de odores. & Controlar os cheiros produzidos. \\
\hline $\begin{array}{l}\text { Gases e Materiais } \\
\text { Particulados }\end{array}$ & $\begin{array}{l}\text { Desenvolver equipamentos não } \\
\text { poluidores; impedir ou gerenciar } \\
\text { os setores produtores. }\end{array}$ & \\
\hline Lixo e Sujeira & $\begin{array}{l}\text { Propiciar educação e } \\
\text { aperfeiçoar hábitos; os cuidados } \\
\text { que as pessoas têm consigo e } \\
\text { suas moradias, devem ter com } \\
\text { os espaços coletivos. }\end{array}$ & $\begin{array}{l}\text { Desenvolver obras que } \\
\text { necessitem o mínimo de } \\
\text { manutenção e produzam o } \\
\text { mínimo de resíduos. }\end{array}$ \\
\hline Insolação & $\begin{array}{l}\text { Viabilizar o adequado } \\
\text { aproveitamento da insolação. }\end{array}$ & $\begin{array}{l}\text { Dosar e controlar a insolação } \\
\text { necessária. }\end{array}$ \\
\hline Ventos & $\begin{array}{l}\text { Propiciar o adequado } \\
\text { aproveitamento e propor normas } \\
\text { que orientem quanto às } \\
\text { implantações que acentuam } \\
\text { problemas com os ventos. }\end{array}$ & $\begin{array}{l}\text { Tirar partido ou bloquear os } \\
\text { ventos quando necessário. }\end{array}$ \\
\hline Umidade & & $\begin{array}{l}\text { Evitar contribuir para aumentar a } \\
\text { elevada umidade do ar e propor } \\
\text { sistemas de umidificação para } \\
\text { os períodos muito secos. }\end{array}$ \\
\hline Temperaturas & & $\begin{array}{l}\text { Lembrar que a sensação térmica } \\
\text { pode ser alterada trabalhando } \\
\text { com a radiação solar (sol- } \\
\text { sombra), os ventos e as } \\
\text { umidades. }\end{array}$ \\
\hline
\end{tabular}


Em termos gerais, constatamos que a adaptabilidade das pessoas é muito maior em espaços livres do que em ambientes internos ou climatizados. Em espaços internos, principalmente naqueles com ar condicionado, as variações climáticas são pequenas, e o organismo passa a ter dificuldades em se adaptar a variações maiores. Ao ar livre, as variações são muito maiores e com o tempo o corpo se habitua, se acomoda. Além disso, nos espaços abertos usamos vestimentas com grande variedade de níveis de isolamento que ajudam na adaptação, às vezes tão pesadas, que seriam inviáveis em espaços internos.

\section{Desdobramentos do trabalho:}

Contribuir para o aprimoramento de normas e legislações de uso e ocupação do solo que leve em consideração o conjunto dos problemas ambientais na perspectiva do longo prazo e da abrangência metropolitana.

Subsidiar estudos de relações de formas de edifícios e de espaços livres nos ambientes urbanos visando melhorar a qualidade ambiental.

Colaborar para que as metas de ensino não fiquem restritas a fornecer informações, mas que objetivem a assimilação dos conhecimentos ao nível intuitivo, através do envolvimento dos alunos na elaboração e realização de experimentos.

Ajudar a quebrar o mito de que a física aplicada à arquitetura é só para especialistas, assim como o profissional vai a campo reconhecer o terreno e o entorno do seu próximo projeto, também pode fazer análises e medições ambientais. 


\section{Bibliografia}

\begin{tabular}{ll}
\hline AFONSO, Cíntia Maria & $\begin{array}{l}\text { Uso e Ocupação do Solo na Zona Costeira do Estado de } \\
\text { São Paulo: Uma Análise Ambiental, São Paulo, Edit. } \\
\text { Annablume, FAPESP,1999. }\end{array}$ \\
\hline AKUTSU, Maria (@1998) & $\begin{array}{l}\text { Método para Avaliação do Desempenho Térmico de } \\
\text { Edificações no Brasil, São Paulo, Tese de Doutorado, } \\
\text { FAUUSP, 1998. }\end{array}$ \\
\hline ALUCCI, Márcia Peinado & $\begin{array}{l}\text { Dimensionamento de Aberturas e Otimização da } \\
\text { Iluminação Natural na Arquitetura, São Paulo, } \\
\text { Universidade Ibirapuera, (Relatório de Pesquisa 2000, } \\
\text { edição no prelo), Cap.3. }\end{array}$ \\
\hline $\begin{array}{l}\text { ALVES, Júlia Falivene } \\
\text { (@1995) }\end{array}$ & $\begin{array}{l}\text { Metrópoles: Cidadania e Qualidade de Vida, São Paulo, } \\
\text { Editora Moderna, 1995. }\end{array}$ \\
\hline ALVIM, Décio Ferraz & $\begin{array}{l}\text { Evolução do Pensamento Humano, Petrópolis, Editora } \\
\text { Vozes Ltda., 1966, }\end{array}$ \\
\hline $\begin{array}{l}\text { ANDRADE, Rui O. de; } \\
\text { TACHIZAWA, Takeshy; }\end{array}$ & $\begin{array}{l}\text { Gestão Ambiental, Enfoque Estratégico Aplicado ao } \\
\text { Desenvolvimento Sustentável, São Paulo, Makron Books, } \\
\text { CARVALHO, Ana B. de }\end{array}$ \\
\hline $\begin{array}{l}\text { ASCE (American Society } \\
\text { of Civil Engineers) }\end{array}$ & $\begin{array}{l}\text { Wind Tunnel Studies of Buildings and Structures, Manual } \\
\text { of_Practice for, New York, ASCE,1997. } \\
\text { Aerospace Division }\end{array}$ \\
(@1997) & \\
\hline ASSIS,
\end{tabular}

ASSIS, Eleonora Sad de Impactos da Forma Urbana na Mudança Climática: Método para Previsão do Comportamento Térmico e Melhoria de Desempenho do Ambiente Urbano, São Paulo,Tese de Doutorado, FAUUSP, 2000.

ATTADIA DA MOTTA, Nível de Satisfação em Conjuntos Habitacionais da Caio Fabio Grande São Paulo (1ํo e $2^{\circ}$ vol.), São Paulo, IPT/FAPESP, 1975.

BARTHES, Roland Elementos de Semiologia, tradução de Izidoro Blikstein, São Paulo, Editora Cultrix/EDUSP, 1971.

BECKER, Berta K. et alii Geografia e Meio Ambiente no Brasil, $2^{\underline{a}}$ ed., São PauloRio de Janeiro, Editora Hucitec, 1998.

BENEVOLO, Leonardo O Último Capítulo da Arquitetura Moderna, tradução de José Eduardo Rodil, São Paulo, Livraria Martins Fontes Editora, 1985.

BERNALDEZ, F. $\quad$ Ecologia y Paisaje, Madrid, H. Blume Ediciones, 1981. Gonzalez

\begin{tabular}{ll}
\hline BITTENCOURT, & Comparando os Programas Breeze e Easyflow como \\
Leonardo S. & Instrumentos de Simulação da Ventilação Natural, in \\
& $\begin{array}{l}\text { Encontro Nacional de Modelos de Simulação de } \\
\text { Ambientes, (pp.177-188), São Paulo, NUTAU, FAUUSP, } \\
1995 .\end{array}$ \\
\hline BLESSMANN, Joaquim & $\begin{array}{l}\text { O Vento na Engenharia Estrutural, Caderno de } \\
\text { Engenharia 10, Porto Alegre, UFRS, 1986. }\end{array}$ \\
\hline BLESSMANN, Joaquim & $\begin{array}{l}\text { Aerodinâmica das Construções, 2ª ed., Porto Alegre, } \\
\text { Sagra, 1990. }\end{array}$ \\
\hline
\end{tabular}


BLOCH, Luiz Laurent Código de Obras e Edificações do Município de São

Paulo: comentado e criticado, São Paulo, Pini, 1993.

BLOOMER, Kent C. y Cuerpo, Memória y Arquitectura, Madrid, H. Blume

MOORE, Charles W. Ediciones, 1982.

BORGES, A. R. Janeiro O Túnel Aerodinâmico do Laboratório Nacional de Engenharia Civil, Lisboa, LNEC, 1968

BORGES, A. R. Janeiro Sobre a Influência da Constituição do Vento Natural na Aerodinâmica das Construções - Tese, LNEC

(Laboratório Nacional de Engenharia Civil), Lisboa, 1969.

BORGES, A. R. Janeiro e An Erosion Technique for Assessing Ground Level Winds,

SARAIVA, Jorge Fort Collins, 5th International Conference on Wind

A.G.(@1979) Engineering, Colorado State University, 1979. (memória 565, Lisboa, LNEC, 1981)

BRANCO, Bernardo José Uma Introdução ao Estudo das Bases Ecológicas da Castello Cultura, Separata da Revista do Museu Paulista, vol. XXI, São Paulo, USP, 1974.

CALVINO, Ítalo As Cidades Invisíveis, Tradução de Diogo Mainard, São Paulo, Companhia das Letras, 1990.

CHARBONNEAU, J. P. Enciclopédia de Ecologia, São Paulo, EPU, EDUSP, (C1977) 1979.

CHICHIERCHIO, Luiz Manual Técnico de lluminação Zenital, São Paulo, Carlos Colorplast, sem data, p.29.

COMITÉ DA BACIA DO Workshop Urbanização e Inundações 1999, Memórias ALTO TIETÉ Documenta 4, São Paulo, Câmara Técnica de Drenagem e Controle de Inundações, 2000.

CORREA, Antonio Bonet Las Claves del Urbanismo, Barcelona, Editorial Planeta S.A., 1995.

DE MARCO, Conrado Elementos de Acústica Arquitetônica, São Paulo, Nobel,

Silva 1982.

DEL RIO, Vicente Introdução ao Desenho Urbano no Processo de Planejamento, São Paulo, Editora Pini, 1990.

DEL RIO, Vicente e Percepção Ambiental : a Experiência Brasileira, São

OLIVEIRA, Lívia Paulo, Studio Nobel/Editora da UFSCar, 1996.

(organizadores)

DUMAZEDIER, Joffre Valores e Conteúdos Culturais do Lazer, tradução de Regina Maria Vieira, São Paulo, Biblioteca Científica SESC, 1980.

ECO, Humberto Como se faz uma Tese, tradução de Gilson César C. de Souza, São Paulo, Editora Perspectiva, 1991.

EMPLASA O Paisagismo nas Grandes Metrópoles, pp. 187-201, in O Desafio Metropolitano, Série Documentos nำ1, São Paulo, Instituto de Geografia da USP, 1977.

EVANS, Benjamin H. Natural Air Flow Around Buildings, College Station, Research Report № 59, Texas Engineering Experiment Station, 1957.

FANGER, P.O. Thermal Comfort, Analysis and Applications in Environmental Engineering, New York, McGraw-Hill Books, 1972. 
FARRET, Ricardo

Libanez (org.)

FAUUSP
O Espaço da Cidade - Contribuição à Análise Urbana, São Paulo, Editora Projeto, 1985.

Paisagem e Ambiente: Ensaios, Edição Especial no 1 e 2, São Paulo, FAU, 1986.

FAUUSP $\quad$ Paisagem e Ambiente, ํㅡㅇ, São Paulo, FAU, 1986.

FIGUEIREDO, Ricardo Engenharia Social, Soluções para Áreas de Risco, São

Brandão

FORSDYKE, A. G.

Paulo, Makron Books, 1994.

Previsão do Tempo e Clima, São Paulo, Melhoramentos-

Edusp, 1975.

FRAMPTON, Kenneth História Crítica de la Arquitectura Moderna, Barcelona, Editorial Gustavo Gili, 1993.

FROTA, Anésia Barros e Manual de Conforto Térmico, São Paulo, Ed. Nobel, 1988.

SCHIFFER, Sueli Ramos

GERGEN, Kenneth Jay

A Psicologia do Intercâmbio de Comportamento, tradução de Dante Moreira Leite, São Paulo, Edgard

Blucher/EDUSP, 1973.

GIVONI, Baruch (@1969) Man, Climate and Architecture, London, Elsevier

Publishing, 1969.

GIVONI, Baruch (@1992) Comfort, Climate Analysis and Building Design Guidlines; in Energy and Building, vol.18, july92.

GONÇALVES, Joana The Environmental Impact of Tall Buildings in Urban

Carla S Centres, London, Architecture Association Graduate School, 1997.

GOVERNO DO ESTADO São Paulo Metrópole, Planejamento e Gestão, Secretaria DE SÃO PAULO da Economia e do Planejamento, São Paulo, Nova Stella Editorial Ltda., 1990.

GRAHAM, Stephen Rumo à Cidade em Tempo Real, pp.13-41, in Da Cidade de Pedra à Cidade Virtual, São Paulo, Agência Estado, 1996.

HALL, Edward Twitchell. A Dimensão Oculta, (tradução de Sonia Coutinho), Rio de (O1966) Janeiro, Francisco Alves, 1977.

HALL, Edward Twitchell. Más Allá de la Cultura, (tradución de Antonio J.

(@1976)

Desmonts), Barcelona, Editorial Gustavo Gili, 1978.

HEGENBERG, Leônidas Significado e Conhecimento, São Paulo, EPU/EDUSP, 1975.

HEIMSTRA, Norman W. Psicologia Ambiental, São Paulo, E.P.U./EDUSP, 1978. e McFARLING, Leslie $\mathrm{H}$ HELLPACH, Willy Geopsique, São Paulo, Edições Paulinas, (c) 1967.

HESSEN, Johannes

Teoria do Conhecimento, tradução de Dr. António Correia, $7^{\underline{a}}$ ed., Coimbra, Armênio Amado-Editora, Sucessor, 1980.

HIGUERAS, Éster Urbanismo Bioclimático - Critérios Medioambientales em la Ordenación de Assentamientos, Madrid, Tese de Doutorado, Escuela Técnica Superior de Arquitectura, 1997.

IIDA, Itiro e Ergonomia,São Paulo, Edição dos Autores/FEl,1978. 


\begin{tabular}{|c|c|}
\hline $\begin{array}{l}\text { INSTITUTO DE } \\
\text { GEOGRAFIA }\end{array}$ & $\begin{array}{l}\text { Cartas de Orientação de Vertentes: Confecção e } \\
\text { Utilização, Cartografia } 4 \text { (Coord. Mário de Biasi), São } \\
\text { Paulo, USP, } 1977 .\end{array}$ \\
\hline INSTITUTO DE & Implantação de Conjuntos Habitacionais - \\
\hline $\begin{array}{l}\text { PESQUISAS } \\
\text { TECNOLÓGICAS }\end{array}$ & $\begin{array}{l}\text { Recomendações para Adequação Climática e Acústica, } \\
\text { São Paulo, } 1986 .\end{array}$ \\
\hline $\begin{array}{l}\text { IZARD, Jean-Louis e } \\
\text { GUYOT, Alain }\end{array}$ & $\begin{array}{l}\text { Arquitectura BBoclimática, Barcelona, Editorial Gustavo } \\
\text { Gili S.A., } 1980 .\end{array}$ \\
\hline JACOBS, Jane (C) 1961) & $\begin{array}{l}\text { The Death and Life of Great American Cities, New York, } \\
\text { Vintage Books Edition, } 1992 .\end{array}$ \\
\hline $\begin{array}{l}\text { JELLICOE, Geoffrey and } \\
\text { Susan }\end{array}$ & $\begin{array}{l}\text { The Landscape of Man, New York, Thames and Hudson } \\
\text { Ltd., } 1995 .\end{array}$ \\
\hline KADE, Gerhard & $\begin{array}{l}\text { O Homem e seu Ambiente, Rio de Janeiro, Editora da } \\
\text { Fundação Getúlio Vargas , } 1975 .\end{array}$ \\
\hline $\begin{array}{l}\text { KOENIGSBERGER, O. } \\
\text { H., INGERSOLL, T. G., } \\
\text { MAYHEW, Alan, y } \\
\text { SZOKOLAY, S. V. }\end{array}$ & $\begin{array}{l}\text { Viviendas y Edifícios en Zonas Cálidas y Tropicales, } \\
\text { Madrid, Ed. Paraninfo, } 1977 .\end{array}$ \\
\hline KONYA, Allan & $\begin{array}{l}\text { Diseño en Climas Cálidos (Manual Práctico), Madrid, } \\
\text { Herman Blume Ediciones, } 1981 .\end{array}$ \\
\hline $\begin{array}{l}\text { LAMBERTS, Roberto; } \\
\text { DUTRA, Luciano e } \\
\text { PEREIRA,Fernando. }\end{array}$ & $\begin{array}{l}\text { Eficiência Energética na Arquitetura, São Paulo, PW } \\
\text { Editores, } 1997 .\end{array}$ \\
\hline $\begin{array}{l}\text { LANGENBUCH, Juergen } \\
\text { R. }\end{array}$ & $\begin{array}{l}\text { A Estruturação da Grande São Paulo, Rio de Janeiro, } \\
\text { Fundação I.B.G.E., } 1971 .\end{array}$ \\
\hline LAURIE, Michael & $\begin{array}{l}\text { Introducción a la Arquitectura del Paisaje, Barcelona, } \\
\text { Editorial Gustavo Gili, } 1983 .\end{array}$ \\
\hline LE CORBUSIER @ 1941 & $\begin{array}{l}\text { A Carta de Atenas, tradução de Rebeca Scherer, São } \\
\text { Paulo, Editora Hucitec/EDUSP, } 1993 .\end{array}$ \\
\hline $\begin{array}{l}\text { LENGEN, Johan van (C) } \\
1980\end{array}$ & $\begin{array}{l}\text { Manual Del Alquitecto Descalzo, México, Editorial } \\
\text { Concepto S.A., } 1983 .\end{array}$ \\
\hline LEPARGNEUR, $\mathrm{H}$. & $\begin{array}{l}\text { Introdução aos Estruturalismos, São Paulo, Editora } \\
\text { Herder/EDUSP, } 1972 .\end{array}$ \\
\hline LIPAI, Alexandre Emílio & $\begin{array}{l}\text { Arquitetura - Interações Homem/Ambiente, Dissertação } \\
\text { de Mestrado, São Paulo, FAUUSP, } 1981 .\end{array}$ \\
\hline LIPAI, Alexandre Emílio & $\begin{array}{l}\text { Arquitetura - Percepções de Uso do Espaço e suas } \\
\text { Múltiplas Realidades, Tese de Doutoramento, São Paulo, } \\
\text { FAUUSP, 1993. }\end{array}$ \\
\hline $\begin{array}{l}\text { LOMBARDO, Magda } \\
\text { Adelaide }\end{array}$ & $\begin{array}{l}\text { Ilha de Calor nas Metrópoles, São Paulo, Editora Hucitec, } \\
1985 .\end{array}$ \\
\hline $\begin{array}{l}\text { LYLE, John Tillman } \\
\text { (C) 1985) }\end{array}$ & $\begin{array}{l}\text { Design for Human Ecosystems, New York, 1985, Van } \\
\text { Nostrand Reinhold Company, p.41. }\end{array}$ \\
\hline LYNCH, Kevin & $\begin{array}{l}\text { A Imagem da Cidade, tradução de Jefferson Luiz } \\
\text { Camargo, São Paulo, Martins Fontes, } 1997 .\end{array}$ \\
\hline MACEDO, Silvio Soares & $\begin{array}{l}\text { Paisagem, Litoral e Urbanização - do Éden à Cidade, } \\
\text { capítulo inicial da tese de Livre Docência, FAUUSP, } 1993 .\end{array}$ \\
\hline MACEDO, Silvio & $\begin{array}{l}\text { Espaços Livres, São Paulo, edição mimeografada da pós- } \\
\text { graduação da FAUUSP, } 1995 .\end{array}$ \\
\hline
\end{tabular}


MACEDO, Silvio Soares Higienópolis e Arredores: Processo de Mutação de Paisagem Urbana, São Paulo, Editora Pini/EDUSP, 1987.

\section{MACEDO, Silvio Soares (org.)}

MARTINEZ, Alfonso Corona

MARTOS, Henry Lesjak e MAIA, Nilson Borlina MASCARÓ, Juan Luís

MASCARÓ, Juan Luís
Anais do II ENEPEA (II Encontro Nacional de Ensino de Paisagismo em Escolas de Arquitetura e Urbanismo do Brasil), São Paulo, Unimarco Editora, 1996. Ensayo sobre el Proyecto, Buenos Aires, CP 67 Editorial, 1990. do Brasil, 1997. Manual de Loteamentos e Urbanização, $2^{2}$ ed., Porto Alegre, Sagra-Luzzato Editores, 1997. Desenho Urbano e Custos de Urbanização, $2^{\mathrm{a}}$ ed., Porto Alegre, D.C.Luzzatto Editores Ltda, 1989.

MASCARÓ, Lúcia E. A. Energia na Edificação, São Paulo, Pro Editores, 1985.

Raffo

MASCARÓ, Lúcia E. A. Ambiência Urbana, Porto Alegre, Sagra-Luzzatto

Raffo

MINISTÉRIO DA Editores, 1996.

ECONOMIA DE BADENCartilha Urbanística do Clima, indicações para Plano

WÜRTTEMBERG Diretor, seqüência 2,Stuttgard, 1995, (tradução de

MONTEIRO, Carlos A. F. Clima e Excepcionalismo, Florianópolis, Editora da UFSC. Francisco de Assis G. da Silva, UFPb, João Pessoa,1998) 1991.

MORAN, Emilio F. $\quad$ Adaptabilidade Humana, tradução de Carlos E. A. Coimbra Jr. e Marcelo S. Brandão, São Paulo, Editora da Universidade de São Paulo, 1994.

MORENO, Júlio (coord.) Da Cidade de Pedra à Cidade Virtual: Contribuição para o Debate sobre o Futuro do nosso Habitat, tradução de Beth Saad, São Paulo, Agência Estado, 1996.

MORENO, Manuel F. Habitação Verticalizada, Habitabilidade e Desenho Navarro Urbano: o caso do Conjunto Habitacional Santa Cruz em São Paulo, Dissertação de Mestrado, São Paulo, FAUUSP, 1991.

MORENO, Manuel F. Ciências do Ambiente, 19aㅡ ed., São Paulo, Editora

Navarro Plêiade, 1996.

MOYNIHAN, Daniel P. $\quad$ O Desafio Urbano, São Paulo, Editora Cultrix, 1972. (org.)

MUELLER, Conrad G. Psicologia Sensorial, Rio de Janeiro, Zahar Editores , 1966.

OKAMOTO, Jun ( 1996 Percepção Ambiental e Comportamento, 2ª ed., São Paulo, IPSIS Gráfica e Editora, São Paulo, 1999.

OLGYAY, Victor (@1963 Arquitectura y Clima: Manual de Diseño Bioclimático para Design with Climate) OLIVEIRA, Antonio Arquitectos y Urbanistas, Barcelona, Gustavo Gili, 1998. Climatologia de Vento e Temperatura para Aviação, São Marcos de José dos Campos, Documentação Técnica do Centro Técnico Aeroespacial, Ministério da Aeronáutica, 1994. ORNSTEIN, Sheila W., Espaços Públicos e Semipúblicos, BoletimTécnico 01, BRUNA, Gilda C. e LIMA, São Paulo, FAUUSP, 1994. Catharina P. C. Santos 
ORNSTEIN, Sheila

Walbe

OWEN, P. R.

PIERSON, Donald

POPE, Alan e RAE JR.,

Willian $\mathrm{H}$.

PORTAS, Nuno

PREFEITURA DO

MUNICÍPIO DE SÃO

PAULO

PREFEITURA DO

MUNICÍPIO DE SÃO

PAULO

PREFEITURA DO

MUNICÍPIO DE SÃO

PAULO

RAMÓN, Fernando

RAND $M^{\mathrm{C}}$ NALLY

COMPANY

REIS FILHO, Nestor

Goulart-

RICKLEFS, Robert. E.

RIVERO, Roberto

RODRIGUES, José

Wasth

ROMERO, Marta A.

Bustos

SAKATA, Francine G.

SALOMON, Décio Vieira

SANTOS, Milton
Ambiente Construído \& Comportamento: a Avaliação PósOcupação e a Qualidade Ambiental, São Paulo, Studio Nobel/FUPAM, 1995.

Saltation of Uniform Grains in AAir, in J.Fluid Mech, vol20, part 2, pp225-242, London, 1964.

Estudos de Ecologia Humana, São Paulo, Livraria Martins Editora, 1970.

Low-Speed Wind Tunnel Testing, New York, John Wiley \& Sons - Interscience Publication, 1984.

A Arquitectura para Hoje, Lisboa, Livraria Sá da Costa, 1964.

Lei Municipal no. 7805 de 01-11-1972; sobre o

Parcelamento, Uso e Ocupação do Solo, São Paulo, Polimapas Editora,1975.

Diagnóstico Cartográfico Ambiental do Município de São

Paulo. Assessoria de Meio Ambiente, São Paulo, Gráfica Municipal, 1993.

Agenda 21 Local: Compromisso do Município de São

Paulo, São Paulo, 1997.

Ropa, Sudor y Arquitecturas, Madrid, H.Blume Ediciones, 1980.

The Earth and Man World Atlas, New York, Rand $\mathrm{M}^{\mathrm{C}}$ Nally, 1976.

Quadro da Arquitetura no Brasil, São Paulo, Editora Perspectiva, Coleção Debates, 1995.

A Economia da Natureza, 3를. ed., Rio de Janeiro, Guanabara Koogan S.A., (C) 1996.

Arquitetura e Clima, Acondicionamento Térmico Natural,

Porto Alegre, Sagra - Luzzatto, 1985.

Documentário Arquitetônico- Relativo à Antiga

Construção Civil no Brasil, 4ª ed., Vol. 1, Belo Horizonte, Editora Itatiaia, 1979.

Princípios Bioclimáticos para o Desenho Urbano, São Paulo, Projeto Editores, 1988.

As Linhas Projetuais da Arquitetura Paisagística no Desenho dos Espaços Livres dos Edifícios de Apartamentos, São Paulo, FAUUSP/FAPESP, 1994.

Como Fazer uma Monografia, Belo Horizonte, Interlivros de Minas Gerais, 1973.

1992: a Redescoberta da Natureza, in Revista de Estudos Avançados nำ 14, Volume 6, São Paulo, Instituto de Estudos Avançados da USP, 1992.

SANTOS, Paulo R. J. dos Política e Ações de Urbanismo e Meio Ambiente do e MAGALHÃES JR., José Município de São Sebastião, Prefeitura de São Sebastião, 1972.

SARAIVA, Jorge A. Gil Aerodinâmica dos Edifícios Altos - Características do Escoamento e Resposta à Turbulência de Formas Prismáticas - Tese, LNEC, Lisboa, 1983. 


\begin{tabular}{|c|c|}
\hline SERRA, Geraldo Gomes- & $\begin{array}{l}\text { Teoria, Simulação e Modelo na Arquitetura, in Anais do } \\
\text { Encontro Nacional de Modelos de Simulação de } \\
\text { Ambientes, São Paulo, NUTAU/FAUUSP, } 1995 .\end{array}$ \\
\hline SEWELL, Granville & $\begin{array}{l}\text { Administração e Controle da Qualidade Ambiental, São } \\
\text { Paulo, EPU, EDUSP, CETESB, } 1978 .\end{array}$ \\
\hline $\begin{array}{l}\text { SILVA, Armando } \\
\text { Cavaleiro e, MALATO, } \\
\text { João José }\end{array}$ & $\begin{array}{l}\text { Geometria da Insolação de Edifícios, Lisboa, LNEC, } \\
\text { Laboratório Nacional de Engenharia Civil, } 1969 .\end{array}$ \\
\hline $\begin{array}{l}\text { SNYDER, James C. e } \\
\text { CATANESE, Anthony J. }\end{array}$ & $\begin{array}{l}\text { Introdução à Arquitetura, Rio de Janeiro, Ed. Campus, } \\
1984 .\end{array}$ \\
\hline SOBRAL, Helena Ribeirc & $\begin{array}{l}\text { O Meio Ambiente e a Cidade de São Paulo, São Paulo, } \\
\text { Makron Books Editora, } 1996 .\end{array}$ \\
\hline SOMEKH, Nadia & $\begin{array}{l}\text { A (Des)verticalização de São Paulo, São Paulo, } \\
\text { Dissertação de Mestrado, FAUUSP, } 1987 .\end{array}$ \\
\hline $\begin{array}{l}\text { SOUZA, Maria Adélia A. } \\
\text { de- }\end{array}$ & $\begin{array}{l}\text { A ldentidade da Metrópole, São Paulo, Editora } \\
\text { Hucitec/EDUSP, } 1994 .\end{array}$ \\
\hline SPIRN, Anne Whiston & $\begin{array}{l}\text { O Jardim de Granito, tradução de Paulo Renato M. } \\
\text { Pellegrino, São Paulo, Editora da Universidade de São } \\
\text { Paulo, } 1995 .\end{array}$ \\
\hline
\end{tabular}

STELLMAN, Jeanne M. e Trabalho e Saúde na Indústria, tradução de Maria Heloiza DAUM, Susan M. $\quad$ C. Capellato, Volume I, II e III, São Paulo, E.P.U./EDUSP, 1975.

STERN, Paul C., YOUNG Mudanças e Agressões ao Meio Ambiente, tradução de Oran R, e DRUCKMAN José Carlos Barbosa dos Santos, São Paulo, Makron Daniel (organizadores) Books Editora, 1993.

SUCHER, David City Comforts - How to Build an Urban Village, Seattle, Washington, City Comforts, Second Printing, 1996.

TARALLI, Cibele Haddad Ambiente Construído e Legislação : o Visível e o Invisível, São Paulo, Tese de Doutorado, FAUUSP, 1997.

TUAN, Yi-Fu Topofilia - Um Estudo da Percepção, Atitudes e Valores do Meio Ambiente, tradução de Lívia de Oliveira, São Paulo, Difel -Difusão Editorial S.A., 1980.

TUAN, Yi-Fu Espaço e Lugar - A Perspectiva da Experiência, tradução de Lívia de Oliveira, São Paulo, Difel - Difusão Editorial S.A., 1983.

TURKIENICZ, Benamy e Desenho Urbano: Anais do II SEDUR - Seminário sobre MALTA, Maurício Desenho Urbano no Brasil, São Paulo, Editora Pini. 1986.

(editores)-

VALE, Brenda y VALE, La Casa Autosuficiente, Madrid, Herman Blume Robert Ediciones, 1981.

VARELA, Jacobo A. Soluções Psicológicas para Problemas Sociais, tradução (C)1971 de Álvaro Cabral, São Paulo, Editora Cultrix/EDUSP, 1975.

VILLALBA, Antonio História de la Construcción Arquitectónica Barcelona, Castro Edicions Universitat Politècnica de Catalunya, 1995. WAISMAN, Marina La Estructura Histórica del Entorno, Buenos Aires, Ediciones Nueva Visión, 1985. 
WALLACE, Bruce Biologia Social (Doenças, Sexo, Comunicação, Comportamento), São Paulo, Editora Livros Técnicos e Científicos, 1978.

WALLACE, Bruce Biologia Social (A Humanidade: suas Necessidades, Ambiente, Ecologia), São Paulo, Editora Livros Técnicos e Científicos, 1978.

WATSON, Donald $\quad$ Climatic Design, EUA, McGraw-Hill Book Company, $(\subset)$ 1983.

WRIGHT, David (C) 1978 Arquitectura Solar Natural, México, Ediciones G. Gili, S.A., 1983.

YÁÑEZ, Guillermo Arquitectura Solar, Aspectos Pasivos, Bioclimatismo e Iluminación Natural, Madrid, M.O.P.U., 1988.

YURGEL, Marlene Urbanismo e Lazer, São Paulo, Livraria Nobel, 1983.

\subsection{Outras Fontes}

BASE

EMBRAESP

EMPLASA
Aerofotogrametria e Projetos S.A., São Paulo.

Empresa Brasileira de Estudos do Patrimônio S/C Ltda., São Paulo.

Empresa Metropolitana de Planejamento da Grande São Paulo S.A.

Cartas do Sistema Cartográfico Metropolitano da Grande

São Paulo.

IAG Instituto Astronômico e Geofísico da USP, Normais

Climatológicas, São Paulo.

INTERSAT Imagens de Satélite, São José dos Campos.

IPT Instituto de Pesquisas Tecnológicas do Estado de São

Paulo, São Paulo.

\subsubsection{Normas Técnicas Brasileiras (agrupadas por palavras chave)}

\section{Acústica}

\begin{tabular}{ll}
\hline $\begin{array}{l}\text { NBR10151/2000 } \\
\text { (NB1095) }\end{array}$ & $\begin{array}{l}\text { Acústica - avaliação do ruído em áreas habitadas, } \\
\text { visando o conforto da comunidade - procedimentos }\end{array}$ \\
\hline NBR12540/92 (TB336) & Grandezas e unidades de acústica \\
\hline NBR14313/99 & $\begin{array}{l}\text { Barreiras acústicas para vias de tráfego - características } \\
\text { construtivas }\end{array}$ \\
\hline
\end{tabular}

\section{Atmosfera}

NBR10736/89 (MB3028) Material particulado na atmosfera - determinação da concentração de fumaça 


\begin{tabular}{ll}
\hline NBR12065/91 (MB3402) & $\begin{array}{l}\text { Atmosfera - determinação da taxa de poeira sedimentável } \\
\text { total }\end{array}$ \\
\hline NBR12979/93 & $\begin{array}{l}\text { Atmosfera - determinação da concentração de monóxido } \\
\text { de carbono por espectrometria de infravermelho não } \\
\text { dispersivo }\end{array}$ \\
\hline NBR13412/95 & $\begin{array}{l}\text { Material particulado em suspensão na atmosfera - } \\
\text { determinação da concentração de partículas inaláveis }\end{array}$ \\
\hline
\end{tabular}

Ar

NBR10085/87 (NB1020) Medição de temperatura em condicionamento de ar

Conforto

NBR10152/87 Níveis de ruído para conforto acústico

NBR6401/80 Instalações centrais de ar condicionado para conforto parâmetros para projeto

lluminação

NBR5382/85 (MB207) Verificação de iluminância em interiores

NBR5413/92 (NB57) Iluminância de interiores

NBR5461/91 (TB23) Iluminação

Odor

NBR14341/99 Água: determinação de odor - método de análise sensorial

NBR9417/86 (MB2385) Solventes orgânicos - verificação do odor

Poluição

NBR8969/85 (TB143) Poluição do Ar

TB143/73 Poluição Sonora

Ruído

NBR7731/83 (NB616) Guia para execução de serviços de medição de ruído aéreo e avaliação dos seus efeitos sobre o homem

NBR8433/95 (MB528) Veículos rodoviários automotores em aceleração determinação do nível de ruído 
Vento

NBR6123/88 (NB599) Forças devidas ao vento em edificações

\section{Outras}

NBR14037/98 Manual de operação, uso e manutenção das edificações - conteúdo e recomendações para elaboração e apresentação

NBR9896/93 (TB145) Glossário de poluição das águas

\subsubsection{Normas Técnicas Internacionais}

International Organization Moderate thermal environments - Determination of the for Standardization $P M V$ and PPD index and specification of the conditions for ISO7730/84 thermal comfort

\subsubsection{Sites na Internet}

\begin{tabular}{ll}
\hline ABNT & $h t t p: / / w w w . a b n t . g o v . b r /$ \\
\hline CETESB & $h t t p: / / w w w . c e t e s b . b r /$ \\
\hline IBAMA & $h t t p: / / w w w . i b a m a . g o v . b r /$ \\
\hline IBGE & $h t t p: / / w w w . i b g e . g o v . b r /$ \\
\hline ISO & $h t t p: / / w w w . i s o . c h /$ \\
\hline PRODAM & $h t t p: / / w w w . p r o d a m . g o v . b r / d p h$ \\
\hline
\end{tabular}




\section{Glossário}

\begin{tabular}{|c|c|}
\hline Albedo & $\begin{array}{l}\text { [Do lat. albedo.] Poder difusor de uma superfície; fração da luz incidente que é } \\
\text { refletida pela superfície. }\end{array}$ \\
\hline Ambiência & $\begin{array}{l}\text { [Do fr. ambiance.] Meio material ou moral onde se vive; meio ambiente: } \mathrm{O} \\
\text { espaço, arquitetonicamente organizado e animado, que constitui um meio } \\
\text { físico e, ao mesmo tempo, meio estético, ou psicológico, preparado para o } \\
\text { exercício de atividades humanas; ambiente. }\end{array}$ \\
\hline Ambiente & $\begin{array}{l}\text { [Do lat. ambiente.] Que cerca ou envolve os seres vivos ou as coisas, por } \\
\text { todos os lados; envolvente; Aquilo que cerca ou envolve os seres vivos ou as } \\
\text { coisas; meio ambiente; Lugar, sítio, espaço, recinto; Meio. "Sistema de } \\
\text { constantes espaciais e temporais de estruturas não humanas, que influencia } \\
\text { os processos biológicos e o comportamento de uma população." KADE, } \\
\text { Gerhard (@1970, p.184). }\end{array}$ \\
\hline Antrópico & $\begin{array}{l}\text { [De antrop(o) + ico.] Relativo ao homem. Relativo à ação do homem sobre a } \\
\text { natureza; ligado à presença humana. }\end{array}$ \\
\hline Antropometria & $\begin{array}{l}\text { [De antrop(o) + metria.] Processo ou técnica de mensuração do corpo humano } \\
\text { ou de suas várias partes. }\end{array}$ \\
\hline Antropomórfico & $\begin{array}{l}\text { [De antrop(o) + morf(o) + ico.] Relativo ao antropomorfismo, ou que é próprio } \\
\text { dele; antropomorfista: conceito antropomórfico. }\end{array}$ \\
\hline Antropomorfismo & $\begin{array}{l}\text { [De antropomorfo + ismo.] Tendência para atribuir, ou a forma de pensamento } \\
\text { que atribui, formas ou características humanas a Deus, deuses, ou quaisquer } \\
\text { outros entes naturais ou sobrenaturais. Filos. Aplicação a algum domínio da } \\
\text { realidade (social, biológico, físico, etc.) de linguagem ou de conceitos próprios } \\
\text { do homem ou do seu comportamento. }\end{array}$ \\
\hline Aquecimento & Ato ou efeito de aquecer(-se). \\
\hline Assentamentos & Ato ou efeito de fixar-se, i. e., de estabelecer residência em determinado lugar: \\
\hline Azimute & $\begin{array}{l}\text { [Do árabe as-sumut, 'caminho', 'direção', < árabe-hispânico simut.] Distância } \\
\text { angular, medida sobre o horizonte, a partir de um ponto origem, geralmente o } \\
\text { norte, no sentido dos ponteiros do relógio. }\end{array}$ \\
\hline Biocenose & $\begin{array}{l}\text { [De bi(o) + cen(o) + ose.] Conjunto de organismos em interação em um } \\
\text { mesmo biótopo; comunidade. } \quad \text { cen(o)- [Do gr. koinós, L, ón.] = 'comum', } \\
\text { 'público'; 'que vive em comunidade': cenobiose, cenologia. }\end{array}$ \\
\hline Biodiversidade & $\begin{array}{l}\text { [De bi(o) + diversidade.] A existência, numa dada região, de uma grande } \\
\text { variedade de espécies, ou de outras categorias taxonômicas (como gêneros, } \\
\text { etc.) de plantas ou de animais. }\end{array}$ \\
\hline Biótopo & $\begin{array}{l}\text { [De bi(o) + topo.] Área física na qual os biótipos adaptados a ela e às } \\
\text { condições ambientais se apresentam praticamente uniformes. }\end{array}$ \\
\hline Ciclo & $\begin{array}{l}\text { [Do gr. kýklos, pelo lat. cyclu.]Série de fenômenos que se sucedem numa } \\
\text { ordem determinada: ciclo das estações; ciclo das horas. Ritmo de sucessão } \\
\text { ou repetição de um fenômeno. Qualquer transformação cujo estado inicial é } \\
\text { igual ao final. Ciclo biogeoquímico. Ecol.: O conjunto dos processos físicos, } \\
\text { químicos e biológicos, considerados como um ciclo, que descreve o } \\
\text { intercâmbio de um elemento químico, entre organismos vivos e o ambiente } \\
\text { abiótico. }\end{array}$ \\
\hline Cidade & $\begin{array}{l}\text { [Do lat. civitate.] Complexo demográfico formado, social e economicamente, } \\
\text { por uma importante concentração populacional não agrícola, i. e., dedicada a } \\
\text { atividades de caráter mercantil, industrial, financeiro e cultural; urbe: "Cidade é } \\
\text { a expressão palpável da necessidade humana de contato, comunicação, } \\
\text { organização e troca, -- numa determinada circunstância físico-social e num } \\
\text { contexto histórico" (Lúcio Costa: Registro de uma Vivência, p.277.) }\end{array}$ \\
\hline Cinestesia & $\begin{array}{l}\text { [De cin }(e)+\text { estes }(i)+\text { ia.] Fisiologia: Sentido pelo qual se percebem os } \\
\text { movimentos musculares, o peso e a posição dos membros. }\end{array}$ \\
\hline
\end{tabular}


Clima [Do gr. klíma, 'inclinação', pelo lat. tard. clima.] Conjunto de condições meteorológicas (temperatura, pressão e ventos, umidade e chuvas) características do estado médio da atmosfera em um ponto da superfície terrestre. Região onde a temperatura e mais condições atmosféricas são, em geral, as mesmas.

Cognitivo [Do lat. cognitus, part. pass. de cognoscere, 'conhecer'] Relativo à cognição, ou ao conhecimento.

Comportamento [De comportar + mento.] Maneira de se comportar; procedimento, conduta. Conjunto de atitudes e reações do indivíduo em face do meio social. $\mathrm{O}$ conjunto das reações que se podem observar num indivíduo, estando este em seu ambiente, e em dadas circunstâncias.

Contaminar [Do lat. contaminare.] Contagiar . Provocar infecção em. Corromper, viciar; contagiar. Microbiol. Depositar matéria que contenha organismos patogênicos (em meio impróprio a tal, como, p. ex., ferida, água potável, etc.). Med. Nucl. Depositar material radioativo em (local inapropriado, principalmente onde possa exercer efeitos dolosos). Contaminação [Do lat. contaminatione.] Ato ou efeito de contaminar(-se).

Contexto [Do lat. contextu.] Conjunto; todo, totalidade. Ambiente.

Controle Ambiental [Do fr. contrôler.] Exercer o controle das variáveis ambientais. Submeter a controle o meio ambiente.

Convecção [Do lat. convectione, 'transporte'; ingl. convection.] Em fluidos, processo de transmissão de calor que é acompanhado por um transporte de massa efetuado pelas correntes que se formam no seio do fluido.

Cultura [Do lat. cultura.] O conjunto de características humanas que não são inatas, e que se criam e se preservam ou aprimoram através da comunicação e cooperação entre indivíduos em sociedade. [Nas ciências humanas, opõe-se por vezes à idéia de natureza, ou de constituição biológica, e está associada a uma capacidade de simbolização considerada própria da vida coletiva e que é a base das interações sociais.]. A parte ou o aspecto da vida coletiva, relacionados à produção e transmissão de conhecimentos, à criação intelectual e artística, etc. Cultura de massa: Cultura imposta pela indústria cultural; Induzir, instigar, incitar

Curva de Nível Isoípsa [De is(o) + gr. hypsos, 'altura'.] É uma abstração geométrica que une todos os pontos que possuem o mesmo nível. Linha que, nas cartas topográficas, liga pontos de uma mesma cota; [Curvas de nível muito juntas indicam terreno muito íngreme, abrupto; maior afastamento de uma para a outra indica região pouco íngreme.]

Desempenho [Dev. de desempenhar.] Ato ou efeito de desempenhar(-se). Execução de um trabalho, atividade, empreendimento, etc., que exige competência e/ou eficiência: Conjunto de características ou de possibilidades de atuação de máquina, motor ou veículo (terrestre, aéreo ou marítimo), tais como velocidade, capacidade de carga, agilidade, autonomia de movimentos, rendimento, etc.:

Diuturno [Do lat. diuturnu.] Que tem longa duração. Ao longo do tempo. Por muito tempo.

Drenagem [Do ingl. drainage, pelo fr. drainage.] Ato ou efeito de drenar. Conjunto de operações e instalações destinadas a remover os excessos de água das superfícies e do subsolo.

Drenagem subterrânea: Drenagem especial, destinada a evitar o excesso de umidade do solo, pelo rebaixamento e controle do nível dos lençóis de água subterrâneos.

Ecossistema [De eco + sistema.]. Ecol.: Conjunto dos relacionamentos mútuos entre determinado meio ambiente e a flora, a fauna e os microrganismos que nele habitam, e que incluem os fatores de equilíbrio geológico, atmosférico, meteorológico e biológico.

Edifício [Do lat. aedificiu.] Construção de alvenaria, madeira, etc., de caráter mais ou menos permanente, que ocupa certo espaço de terreno, é geralmente limitada por paredes e teto, edificação, casa, prédio, imóvel: Prédio de vários andares. 


\begin{tabular}{|c|c|}
\hline Edilícia & $\begin{array}{l}\text { [Do lat. aedilitiu.] Edilício, Concernente à edificação de obras, Normas } \\
\text { edilícias. }\end{array}$ \\
\hline Emitir & $\begin{array}{l}\text { [Do lat. emittere.] Lançar fora de si, Pôr em circulação, Exprimir, pronunciar, } \\
\text { enunciar, Soltar, lançar, desferir, Enviar, expedir. (comparar com Imitir) }\end{array}$ \\
\hline$\overline{\text { Energia }}$ & $\begin{array}{l}\text { [Do gr. enérgeia, pelo lat. energia.] Maneira como se exerce uma força. Fís. } \\
\text { Propriedade de um sistema que lhe permite realizar trabalho. A energia pode } \\
\text { ter várias formas (calorífica, cinética, elétrica, eletromagnética, mecânica, } \\
\text { potencial, química, radiante), transformáveis umas nas outras, e cada uma } \\
\text { capaz de provocar fenômenos bem determinados e característicos nos } \\
\text { sistemas físicos. Em todas as transformações de energia há completa } \\
\text { conservação dela, i. e., a energia não pode ser criada, mas apenas } \\
\text { transformada (primeiro princípio da termodinâmica). A massa de um corpo } \\
\text { pode-se transformar em energia, e a energia sob forma radiante pode } \\
\text { transformar-se em um corpúsculo com massa [símb.: E ]. }\end{array}$ \\
\hline Entropia & $\begin{array}{l}\text { [Do gr. entropé, 'volta', + ia1.] Função termodinâmica de estado, associada à } \\
\text { organização espacial e energética das partículas de um sistema. Medida da } \\
\text { quantidade de desordem dum sistema [símb.: S ]. }\end{array}$ \\
\hline Equinócio & $\begin{array}{l}\text { [Do lat. aequinoctiu.] Ponto da órbita da Terra em que se registra uma igual } \\
\text { duração do dia e da noite, o que sucede nos dias } 21 \text { de março e } 23 \text { de } \\
\text { setembro. Qualquer das duas interseções do círculo da eclíptica com o } \\
\text { círculo do equador celeste. Instante em que o Sol, no seu movimento anual } \\
\text { aparente, corta o equador celeste. }\end{array}$ \\
\hline Equipamentos & $\begin{array}{l}\text { [Do fr. équipement.] O conjunto de tudo aquilo que serve para equipar, } \\
\text { prover, abastecer: equipamento de caça; equipamento de mergulho. }\end{array}$ \\
\hline Ergonomia & $\begin{array}{l}\text { [De gr. erg }(0)+\text { nom }(0)+\text { ia.] Conjunto de estudos que visam à organização } \\
\text { metódica do trabalho em função do fim proposto e das relações entre o } \\
\text { homem e a máquina. Ciência da adaptação do trabalho ao homem, ciência } \\
\text { que procura melhorar a atividade produtiva e o homem. }\end{array}$ \\
\hline Escala de Valor & $\begin{array}{l}\text { [Do lat. tard. valore.] Conjunto de qualidades pelas quais determinadas } \\
\text { pessoas ou coisas são estimáveis, em maior ou menor grau; mérito ou } \\
\text { merecimento intrínseco; valia: }\end{array}$ \\
\hline Espaço & $\begin{array}{l}\text { [Do lat. spatiu.] Distância entre dois pontos, ou a área ou o volume entre } \\
\text { limites determinados: O acidente com o pedestre resultou do estreito espaço } \\
\text { da calçada; A casa foi construída num espaço pequeno. Lugar mais ou } \\
\text { menos bem delimitado, cuja área pode conter alguma coisa; lugar: Na casa há } \\
\text { espaço para cinco pessoas; O artigo não desenvolve bem o tema por falta de } \\
\text { espaço. Período ou intervalo de tempo Vagar, demora, delonga: A } \\
\text { preparação da aula demanda maior espaço. Fig. Meio, âmbito que lembra o } \\
\text { espaço material: espaço cultural; espaço psicológico. }\end{array}$ \\
\hline Fonte de Energia & $\begin{array}{l}\text { [Do lat. fonte.] Aquilo que origina ou produz energia Circuito capaz de fornecer } \\
\text { energia, em condições controladas; fonte de alimentação. Sistema emissor de } \\
\text { radiação }\end{array}$ \\
\hline
\end{tabular}

Habitabilidade [De habitável + (i)dade.] Qualidade de habitável; possibilidade de ser habitado.

\begin{tabular}{|c|c|}
\hline Habitar & $\begin{array}{l}\text { [Do lat. habitare.] Ocupar como residência; residir, morar, viver em; Tornar } \\
\text { habitado; ocupar, povoar; Estar domiciliado; coabitar. }\end{array}$ \\
\hline$\overline{\text { Higiene }}$ & $\begin{array}{l}\text { [Do fr. hygiène < gr. hygieinón, 'saúde', neutro subst. de hygeinós, é, on, 'que } \\
\text { contribui para a saúde'.] Ramo da medicina que visa à prevenção da doença. } \\
\text { Fig. Limpeza, asseio. }\end{array}$ \\
\hline Hinterlândia & $\begin{array}{l}\text { [Adapt. do alemão Hinterland.] Território situado por trás de uma costa } \\
\text { marítima ou de um rio; interior. }\end{array}$ \\
\hline Ideais & $\begin{array}{l}\text { [Do lat. tard. ideale.] Que existe somente na idéia; imaginário, fantástico Que } \\
\text { é a síntese de tudo a que aspiramos, de toda a perfeição que concebemos ou } \\
\text { se pode conceber: Aquilo que é objeto da nossa mais alta aspiração } \\
\text { intelectual, estética, espiritual, afetiva, ou de ordem prática: ideal de cultura; O } \\
\text { modelo sonhado ou ideado pela fantasia de um artista, de um poeta. }\end{array}$ \\
\hline
\end{tabular}




\begin{tabular}{|c|c|}
\hline Iluminância & $\begin{array}{l}\text { [De iluminar + ância.] lluminamento; Iluminação; Fluxo luminoso incidente por } \\
\text { unidade de área de uma superfície iluminada; }\end{array}$ \\
\hline Imitir & $\begin{array}{l}\text { [Do lat. imittere, com mudança de conjug.] Fazer entrar; pôr para dentro; } \\
\text { meter. }\end{array}$ \\
\hline Impermeável & $\begin{array}{l}\text { [De im-2 + permeável.] Que não se deixa atravessar por fluidos, } \\
\text { especialmente pela água: O vidro é impermeável; Aquele terreno é } \\
\text { impermeável. Impermeabilizado: tecido impermeável. }\end{array}$ \\
\hline Incorporador & $\begin{array}{l}\text { [De incorporar + dor.] Aquele que promove a incorporação de prédio(s) de , } \\
\text { lojas apartamentos, etc., em condomínio. Fundador de uma sociedade } \\
\text { anônima }\end{array}$ \\
\hline Incorporar & $\begin{array}{l}\text { [Do lat. incorporare.] Juntar num só corpo; dar unidade a; reunir: Realizar } \\
\text { contrato para construção de (edifício de apartamentos, lojas, etc.), em } \\
\text { condomínio, começando logo a vender, em prestações, as futuras unidades. } \\
\text { Unir, reunir, juntar, em um só corpo ou um só todo: Incorporou mais um bem } \\
\text { de raiz no seu patrimônio; Incorporou mais um título à sua valiosa obra } \\
\text { literária. Tomar forma corpórea; materializar-se: Reunir-se, juntar-se, } \\
\text { congregar-se. }\end{array}$ \\
\hline Insolação & $\begin{array}{l}\text { [Do lat. insolatione.] Exposição ao sol A quantidade de radiação solar } \\
\text { recebida pela superfície terrestre por uma unidade de área. Varia de acordo } \\
\text { com a estação, a latitude, a transparência da atmosfera, o aspecto e/ou a } \\
\text { declividade do solo, etc. }\end{array}$ \\
\hline Intuições & $\begin{array}{l}\text { [Do lat. tard. intuitione, 'imagem refletida por um espelho', com sentido } \\
\text { filosófico em lat. escolástico.] Ato de ver, perceber, discernir; percepção clara } \\
\text { e imediata; discernimento instantâneo; visão. Ato ou capacidade de } \\
\text { pressentir; pressentimento: Apreensão direta, imediata e atual de um objeto } \\
\text { na sua realidade individual. }\end{array}$ \\
\hline Lazer & $\begin{array}{l}\text { [Do lat. licere, 'ser lícito', pelo arcaísmo lezer.] Ócio, descanso, folga, vagar. } \\
\text { Tempo de que se pode livremente dispor, uma vez cumpridos os afazeres } \\
\text { habituais. Atividade praticada nesse tempo; divertimento, entretenimento, } \\
\text { distração, recreio. Tecnicamente o conceituamos como sendo o ócio } \\
\text { repousante, implicando em locais tranqüilos. }\end{array}$ \\
\hline Meteorologia & $\begin{array}{l}\text { [Do gr. meteorología.] Ciência que investiga os fenômenos atmosféricos, e } \\
\text { cujas observações possibilitam a previsão do tempo. }\end{array}$ \\
\hline Metrópole & $\begin{array}{l}\text { [Do gr. metrópolis, 'cidade mãe', pelo lat. metropole.] Cidade principal, ou } \\
\text { capital de província ou de estado. Grande cidade; cidade importante. Nação, } \\
\text { em relação às suas colônias:. A principal cidade que exerce influência } \\
\text { funcional, econômica e social sobre as cidades menores de uma região } \\
\text { metropolitana. Cidade que, por suas atividades financeiras, de gestão e de } \\
\text { informação, alcançam uma esfera de influência nacional e, mesmo, mundial, } \\
\text { como, p. ex., Nova lorque, Paris, São Paulo,... }\end{array}$ \\
\hline Microclima & $\begin{array}{l}\text { [De micr(o) + clima.] Conjunto de condições climáticas existentes numa área } \\
\text { relativamente restrita, geralmente próxima à superfície, influenciadas pela } \\
\text { vegetação e constituição do solo. }\end{array}$ \\
\hline Micrômetro & $\begin{array}{l}\text { [De micr(o) + metro.] Unidade de medida de comprimento, igual à milionésima } \\
\text { parte do metro [símb.: } \mu \mathrm{m}] \text {. }\end{array}$ \\
\hline Montante & $\begin{array}{l}\text { [De montar + nte.] Direção de onde correm as águas duma corrente fluvial. } \\
\text { Enchente da maré; maré alta. [Antônimo: vazante.] Arquitetura: Qualquer peça } \\
\text { vertical de sustentação que, numa estrutura, não possa ser considerada } \\
\text { coluna ou pilastra A montante: Para o lado da nascente (de um rio) } \\
\text { [Antônimo: a jusante.] }\end{array}$ \\
\hline Morfologia & $\begin{array}{l}\text { [Do gr. morphl, ás.] 'forma', morfozoário. [De morf(o) + logia.] Tratado das } \\
\text { formas que a matéria pode tomar. }\end{array}$ \\
\hline Município & $\begin{array}{l}\text { [Do lat. municipiu.] Circunscrição administrativa autônoma do estado, } \\
\text { governada por um prefeito e uma câmara de vereadores; municipalidade, } \\
\text { concelho. }\end{array}$ \\
\hline Ocupação & $\begin{array}{l}\text { [Do lat. occupatione.] Ato de ocupar, ou de se apoderar de algo; posse. Ato } \\
\text { de ocupar-se, de trabalhar em algo. }\end{array}$ \\
\hline Orografia & $\begin{array}{l}\text { [De or(o) + grafia.] Descrição das montanhas. Orográfico [De orografia + } \\
\text { ico.] Relativo a orografia. }\end{array}$ \\
\hline
\end{tabular}




\begin{tabular}{ll}
\hline Parcelamento & [De parcelar + mento.] Ato, efeito ou maneira de parcelar. Parcelamento da \\
& terra. Urb.: Divisão de uma área de terreno em lotes, sob a forma de \\
& desmembramento ou loteamento. Parcelamento em condomínio. Urb.: \\
& Divisão de uma área de terreno em frações ideais, demarcadas ou não em \\
& áreas de uso privativo, e cujos acessos e vias de circulação internas são de \\
& propriedade e responsabilidade de condôminos. \\
\hline Percepção & [Do lat. perceptione.] Ato, efeito ou faculdade de perceber. Perceptibilidade \\
& [Do lat. med. perceptibilitate.] Qualidade de perceptível. Faculdade de \\
& perceber. \\
\hline Perceptivo & [Do lat. perceptus (v. perceptível) + ivo.] Relativo à percepção. Que tem a \\
& faculdade de perceber. \\
\hline Permeabilidade & [De permeável + (i)dade, seg. o padrão erudito.] Qualidade de permeável.
\end{tabular}

\begin{tabular}{ll}
\hline Permeável & [Do lat. tard. permeabile.] Que se pode permear; que pode ser repassado ou \\
& transpassado; que deixa passar: Essa parede é permeável ao som. \\
\hline Planta & [Do lat. planta.] Arquit. Desenho da projeção horizontal de um objeto, terreno, \\
& de parte de uma construção, etc. Planta baixa. Arquit.: Representação gráfica \\
& do corte horizontal de um edifício, e que passa, geralmente., acima do plano \\
& dos peitoris das janelas. Planta de localização. Arquit. Urb. :Representação \\
& gráfica da posição exata de um terreno, e que compreende a região onde está \\
& localizado, com logradouros e terrenos vizinhos. Planta topográfica: \\
& Representação gráfica, convencional e minuciosa, de uma pequena área da \\
& superfície terrestre; carta topográfica. $\quad$ [Do ingl. plant.] Instalação \\
& produtiva; fábrica. \\
\hline Poluição & ([Do lat. pollutione, por via popular.] Ato ou efeito de poluir(-se).[Forma. \\
& paralela.: polução.] \\
\hline Poluir & [Do lat. polluere.] Sujar, corromper, tornando prejudicial ao ambiente e seres \\
& vivos. Manchar ou macular a honra, o lustre, a dignidade de; profanar, \\
& deslustrar, corromper, desdourar, conspurcar: poluir homens de bem. \\
\hline Qualidade & [Do lat. qualitate.] Propriedade, atributo ou condição das coisas ou das \\
pessoas capaz de distingui-las das outras e de lhes determinar a natureza. \\
Numa escala de valores, qualidade que permite avaliar e, conseqüentemente, \\
aprovar, aceitar ou recusar, qualquer coisa. Condição, posição, função. Na \\
perspectiva dialética, categoria fundamental que designa a diversidade de \\
relações pelas quais, cada coisa, a cada momento, vem a ser tal como é. \\
Qualidade primária. Filos. Característica geométrica ou mecânica das coisas \\
(p. ex., a extensão, a forma, o movimento), que é considerada inseparável \\
quer seja do conceito, quer seja da materialidade delas; qualidade primeira. \\
Qualidade secundária. Filos. Qualidade relacionada à percepção sensorial \\
imediata de uma coisa (cor, sabor, cheiro, temperatura, textura) cuja \\
objetividade é, por isso, problemática.
\end{tabular}

\begin{tabular}{ll}
\hline $\begin{array}{l}\text { Recrear- } \\
\text { Recreação }\end{array}$ & $\begin{array}{l}\text { [Do lat. recreare.] Proporcionar recreio a; divertir: Causar prazer a; alegrar: } \\
\text { Sentir prazer ou satisfação. Divertir-se; folgar, brincar. Podemos considera-lo } \\
\text { como Lazer Ativo. }\end{array}$ \\
\hline Recuo & $\begin{array}{l}\text { [Dev. de recuar.] Parte de terreno situado para trás de um limite } \\
\text { convencionado. Urb.: Distância mínima obrigatória, estipulada por } \\
\text { legislação, que as fachadas de uma edificação devem manter com relação às } \\
\text { divisas do terreno. }\end{array}$ \\
\hline Relações & $\begin{array}{l}\text { [Pl. de relação.] Conhecimento recíproco e/ou convivência entre pessoas: } \\
\text { relações de amizade; relações profissionais. As pessoas com quem se } \\
\text { mantêm relações. As ligações e associações entre grupos. }\end{array}$ \\
\hline Sazonal & [De sazão + al, seg. o padrão erudito.] Relativo a sazão ou estação. Próprio \\
& de, ou que se verifica em uma sazão ou estação. Sinônimo: Estacional. \\
\hline Sensação & [Do lat. med. sensatione.] Fisiol. Impressão causada numa formação \\
& $\begin{array}{l}\text { receptora por um estímulo, e que, por via aferente, é conduzida ao sistema } \\
\text { nervoso central. Psicol. Processo sensorial consciente correlacionado com } \\
\text { um processo fisiológico, e que proporciona o conhecimento do mundo externo. }\end{array}$ \\
\hline
\end{tabular}


Sensorial [Do fr. sensoriel.] Referente a sensório Pertencente ou relativo a sensação: órgãos sensoriais.

Sinestesia [De sin + estes(i) + ia.]Psicol. Relação subjetiva que se estabelece espontaneamente entre uma percepção e outra que pertença ao domínio de um sentido diferente (p. ex., um perfume que evoca uma cor, um som que evoca uma imagem, etc.). Sensação, em uma parte do corpo, produzida pelo estímulo em outra parte.

Sistemas [Do gr. sýstema, 'reunião', 'grupo', pelo lat. tard. systema.] Conjunto de elementos, materiais ou ideais, entre os quais se possa encontrar ou definir alguma relação. Disposição das partes ou dos elementos de um todo, coordenados entre si, e que funcionam como estrutura organizada. Conjunto de instituições políticas ou sociais, e dos métodos por elas adotados, encarados quer do ponto de vista teórico, quer do de sua aplicação prática: Reunião coordenada e lógica de princípios ou idéias relacionadas de modo que abranjam um campo do conhecimento: o sistema de Kant; o sistema de Ptolomeu. Conjunto ordenado de meios de ação ou de idéias, tendente a um resultado; plano, método: sistema de vida; sistema de trabalho; sistema de defesa. Modo, maneira, forma, jeito. Qualquer método ou plano especialmente destinado a marcar, medir ou classificar alguma coisa: sistema métrico; sistema decimal. Sistema construtivo. Arquit. Constr: Numa construção, o conjunto de regras práticas para o uso adequado e coordenado de materiais e de mão-de-obra.

Solstício [Do lat. solstitiu.] Instante em que o Sol está em sua maior declinação boreal ou austral, e a partir da qual deixa de afastar-se do equador. [Os solstícios situam-se, respectivamente, nos dias 22 ou 23 de junho para a maior declinação boreal, e nos dias 22 ou 23 de dezembro para a maior declinação austral do Sol. No hemisfério sul, a primeira data se denomina solstício de inverno e a segunda solstício de verão; e, como as estações são opostas nos dois hemisférios, essas denominações invertem-se no hemisfério norte.]

Sombra

[Do lat. umbra, pelo lat. vulg. sulumbra (= sub illa umbra) e pelo arcaísmo: soombra.] Espaço sem luz, ou escurecido pela interposição de um corpo opaco: a sombra de uma árvore. Zona privada de luz em virtude da interposição de um corpo opaco: Lugar abrigado dos raios solares: Meu apartamento está no lado da sombra. Ausência de luz solar; noite. Escuridão, treva(s); Região não iluminada; obscuridade, escuridão, escuro.

\begin{tabular}{ll}
\hline Sustentável & [Do lat. sustentabile.] Que se pode sustentar. Capaz de se manter mais ou \\
& menos constante, ou estável, por longo período.
\end{tabular}

Tecido Urbano [Part. de tecer.] Que se teceu. Urdido, preparado. Tecido urbano. Urb: A cidade, onde as áreas construídas, os vazios, o sistema viário, e todos os demais elementos são comparados metaforicamente ao entrelaçamento de fios de um tecido; malha urbana.

\begin{tabular}{|c|c|}
\hline Técnico & $\begin{array}{l}\text { [Do gr. technikós, 'relativo à arte', pelo lat. technicu.] Peculiar a uma } \\
\text { determinada arte, ofício, profissão ou ciência: termo técnico. }\end{array}$ \\
\hline Topo & $\begin{array}{l}\text { [top(o) Do gr. tópos,] = 'lugar', 'localidade': topônimo, toporama.[Equiv.: - } \\
\text { top(o), topo: atópico, isótopo.] }\end{array}$ \\
\hline Topografia & $\begin{array}{l}\text { [Do gr. topographía.] Descrição minuciosa de uma localidade; topologia. Arte } \\
\text { de representar no papel a configuração duma porção do terreno com todos os } \\
\text { acidentes e objetos que se achem à sua superfície. }\end{array}$ \\
\hline $\begin{array}{l}\text { Umidade Relativa } \\
\text { do } \mathrm{Ar}\end{array}$ & $\begin{array}{l}\text { [Do lat. humidu.] Levemente molhado. Impregnado de água, de líquido, de } \\
\text { vapor: Umidade relativa. Fís.: Razão entre a pressão de vapor de água na } \\
\text { atmosfera e a pressão de vapor saturado na mesma temperatura. }\end{array}$ \\
\hline Urbano & $\begin{array}{l}\text { [Do lat. urbanu.] Relativo ou pertencente à cidade: planejamento urbano; } \\
\text { transportes urbanos. Que tem características de cidade: agrupamento } \\
\text { urbano. }\end{array}$ \\
\hline$\overline{\text { Vento }}$ & $\begin{array}{l}\text { [Do lat. ventu.] O ar em movimento, fenômeno ocasionado sobretudo pelas } \\
\text { diferenças de temperatura (e, portanto, de pressões) nas várias regiões } \\
\text { atmosféricas. Ar posto artificialmente em movimento, por leque, ventilador, } \\
\text { etc. Ar, atmosfera. }\end{array}$ \\
\hline
\end{tabular}


[Do b.lat. verticale.] Perpendicular ao plano horizontal. Que segue a direção do fio de prumo; aprumado. Situado por cima da cabeça. Verticalizar[De vertical + izar.] Dar posição vertical a.

Verticalização [De verticalizar + ção.] Ato ou efeito de verticalizar.

Zoneamento

[De zonear + mento.] Divisão racional de uma área em setores sujeitos a normas específicas para o desenvolvimento de certas atividades, para a conservação do meio ambiente, ou para a preservação de patrimônio cultural, etc. 




\subsection{Anexo A}

Caracterização Física e Ambiental do Município de São Paulo

Mapa 1 Caracterização Física, sobreposição de: Curvas de nível, Corpos d'água e Áreas verdes com mais de $10.000 \mathrm{~m}^{2}$ (fontes: EMPLASA e Diagnóstico Cartográfico Ambiental do Município de São Paulo PMSP).

Mapa 2 Caracterização Ambiental, sobreposição de: Pontos de inundações, Dióxido de Enxofre, Material Particulado, Índice de Qualidade das Águas e Áreas Industriais (fontes: CETESB e Secretaria das Administrações Regionais da PMSP). 


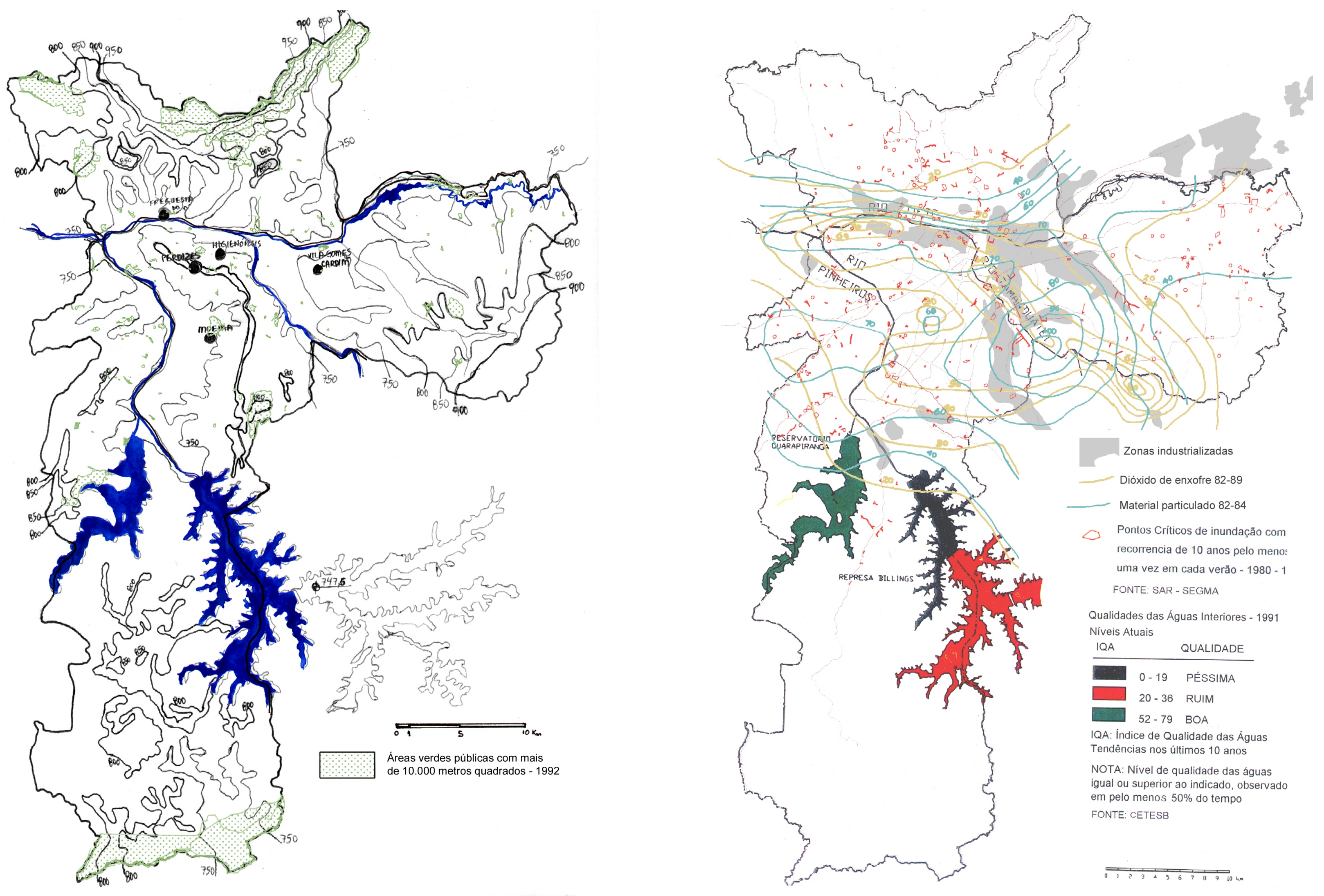


\subsection{Anexo B}

Maquetes Eletrônicas das Cinco Áreas Utilizadas para as Análises

Centro: Higienópolis (página 173)

Norte: Freguesia do Ó (página 174)

Sul: Moema (página 175)

Leste: Vila Gomes Cardim - Tatuapé (página 176)

Oeste: Perdizes (página 177) 
Higienópolis
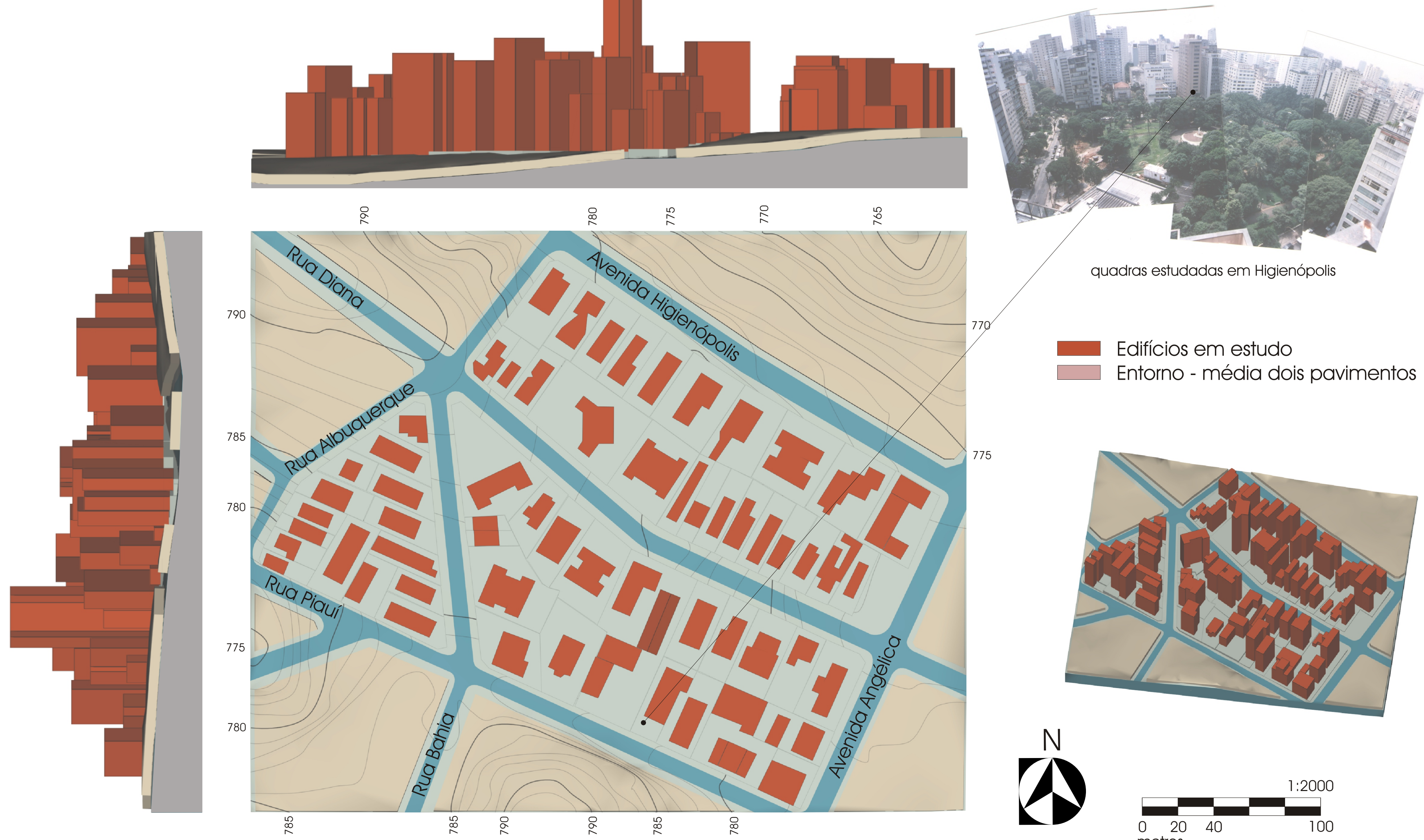

$\Delta$

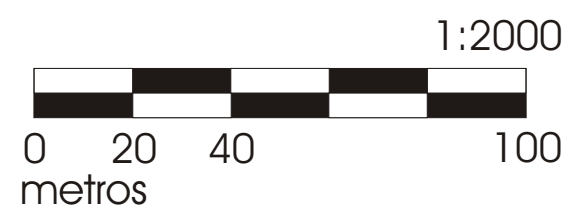




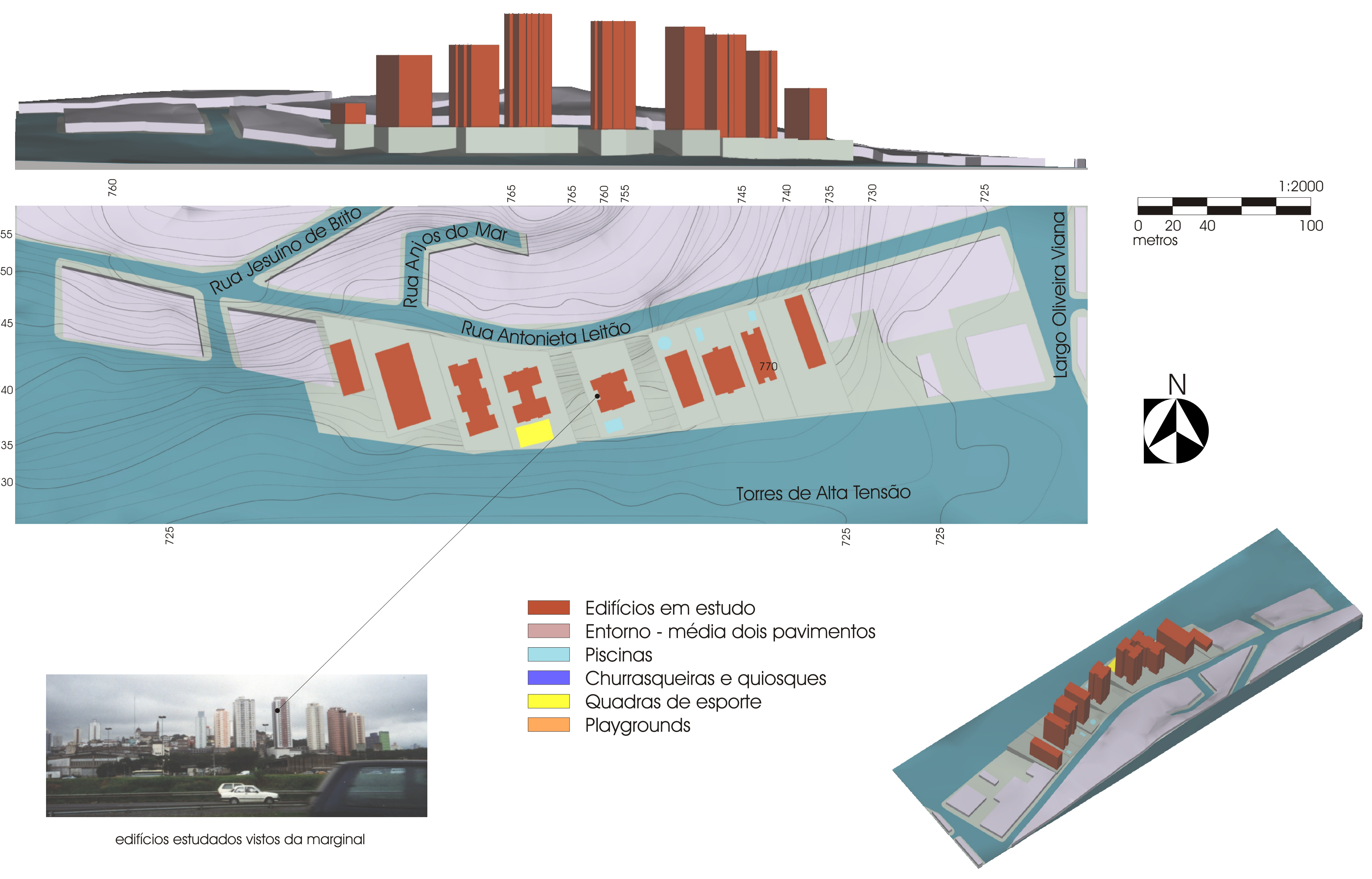




\section{Moema}

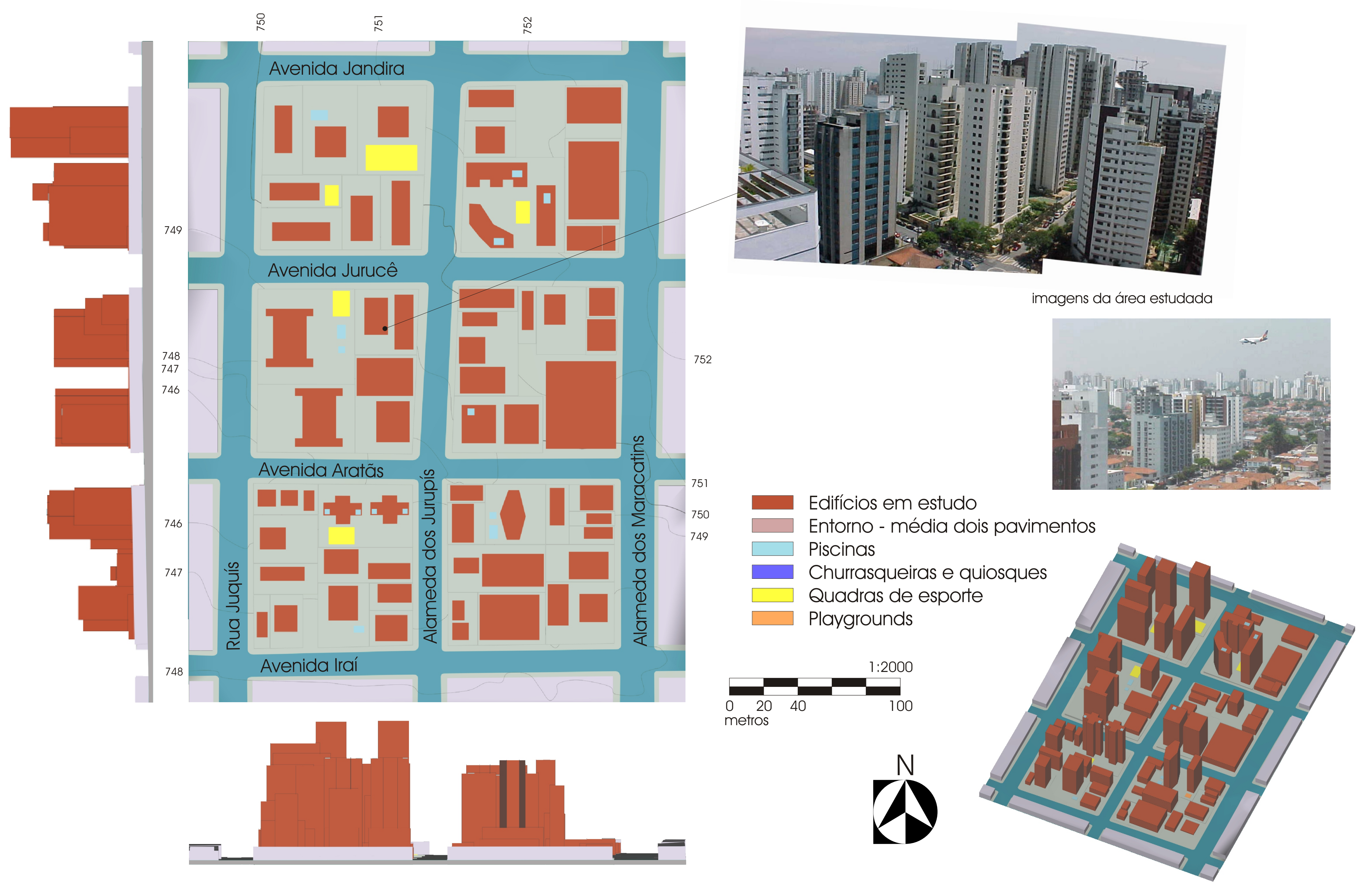




\section{Tatuapé-Vila Gomes Cardim}

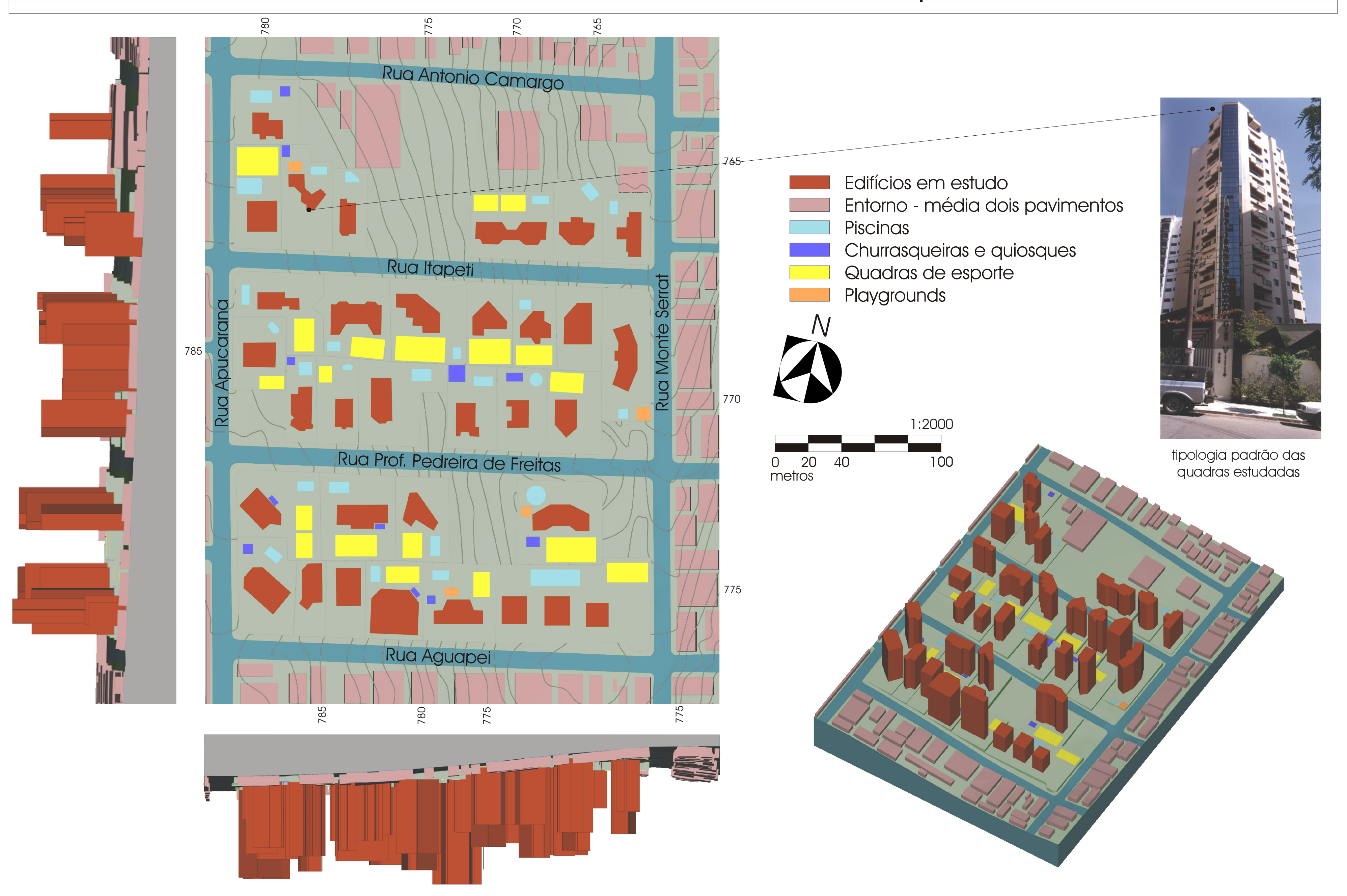




\section{Perdizes-Pompéia}
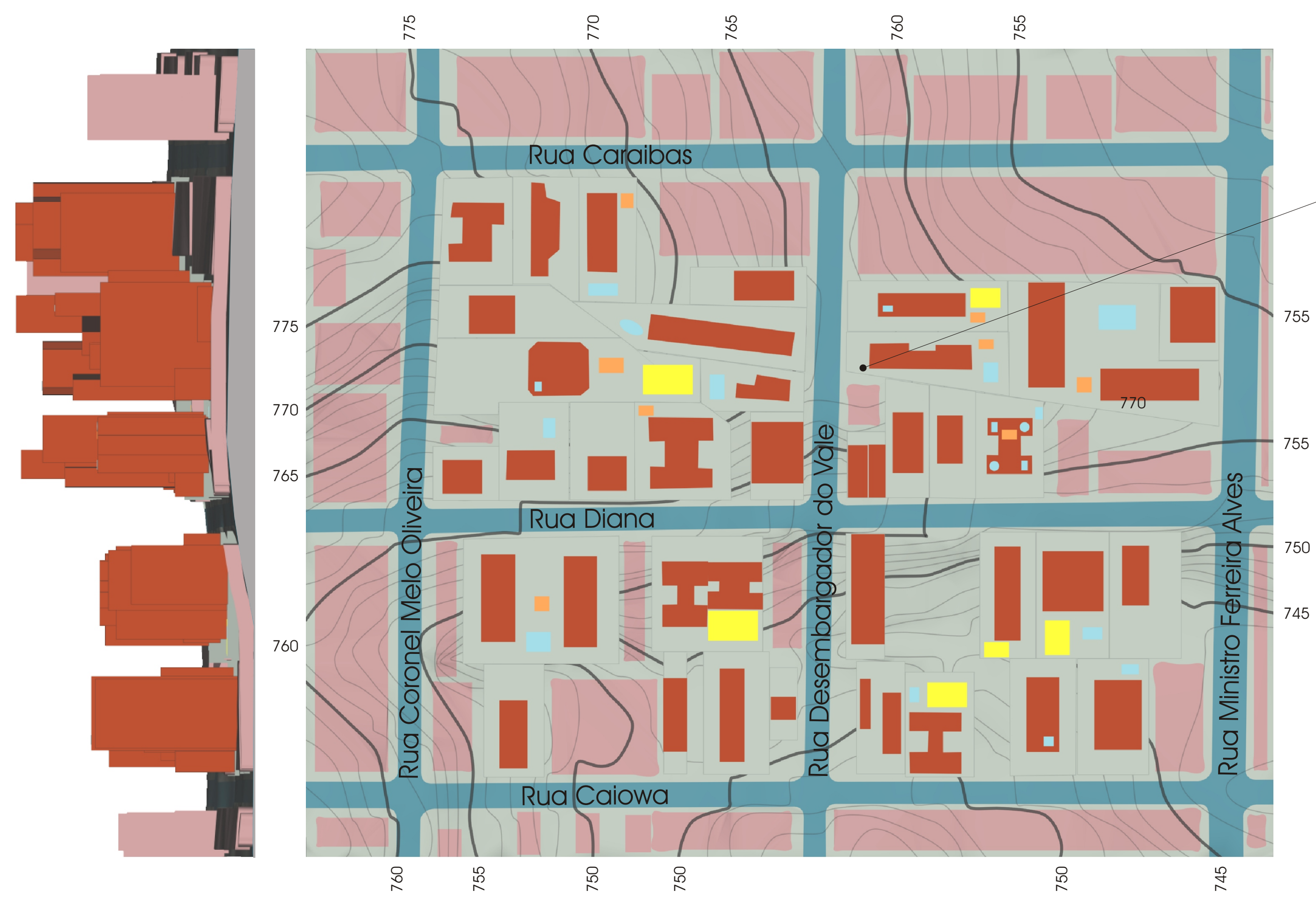

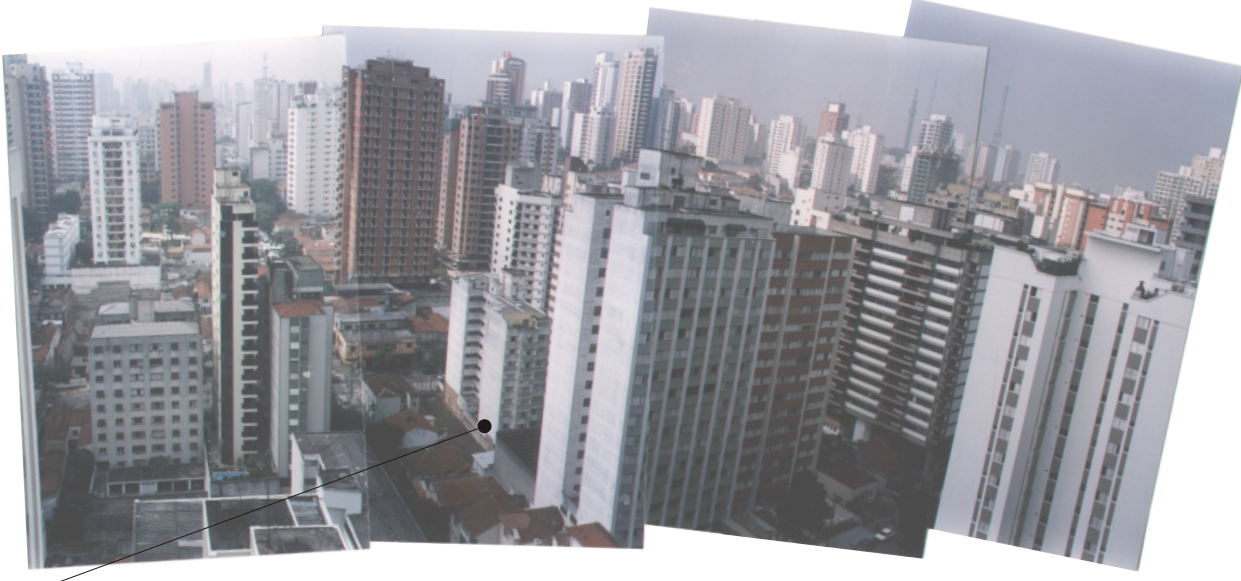

vista das quadras abrangidas pelo estudo

Edifícios em estudo

Entorno - média dois pavimentos

Piscinas

Churrasqueiras e quiosques

Quadras de esporte

Playgrounds

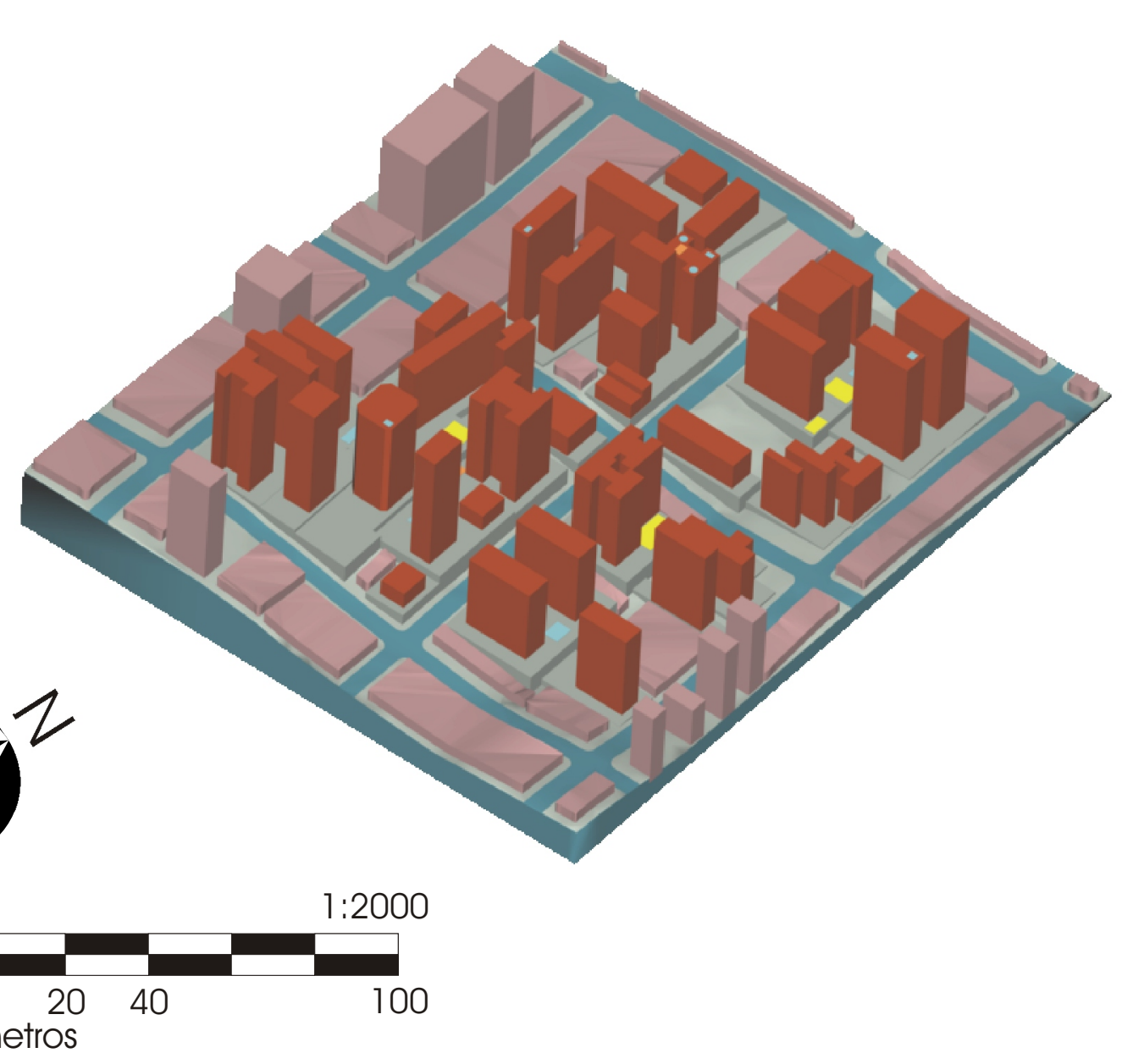




\subsection{Anexo C}

Análise da Qualidade Ambiental nos Espaços Livres

Estudo realizado nos espaços livres de um condomínio com dois edifícios de apartamentos situados em Vila Carrão, Zona Leste da Cidade de São Paulo.

Caracterização, Medições, Análises, Comentários e Fotos (Página 179).

Implantação, Estudos de Insolação e Estudos Eólicos (Página 180). 


\section{Análise da Qualidade Ambiental nos Espaços Livres}

Munidos de higrômetro, anemômetro, termômetro de globo, psicrômetro, relógio de sol, câmera fotográfica e bloco de anotaçōes, fizemos mediçós em condiçōes climáticas variadas, dia encoberto e frio, dia ensolarado e quente. Obtivemos os seguintes dados: direção do norte verdadeiro, temperatura radiante média, temperaturas seca

úmida, direção e velocidade dos ventos e umidade relativa.

Com as observaçoes e medços feitas no local, traçamos as áreas sombreadas e o fluxo dos ventos. A partir das informações das medições, pudemos elaborar o seguinte diagnóstico:

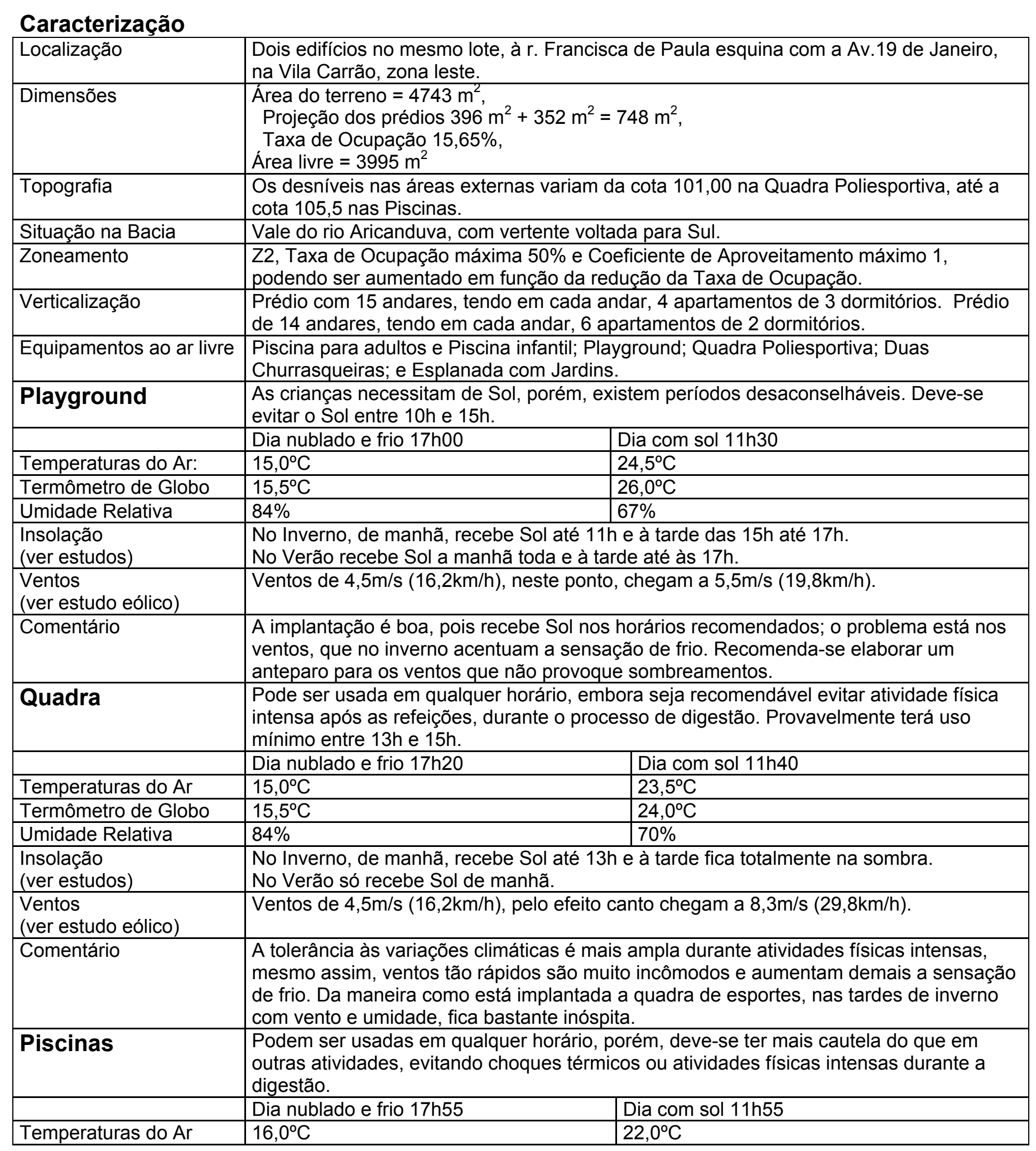

\begin{tabular}{|c|c|c|}
\hline Termômetro de Globo & $17,0^{\circ} \mathrm{C}$ & $26,0^{\circ} \mathrm{C}$ \\
\hline Umidade Relativa & $82 \%$ & $72 \%$ \\
\hline $\begin{array}{l}\text { Insolação } \\
\text { (ver estudos) }\end{array}$ & \multicolumn{2}{|c|}{$\begin{array}{l}\text { No Inverno, recebe Sol o dia todo. } \\
\text { No Verão, a piscina infantil está um pouco prejudicada, só recebendo Sol após às } 9 \mathrm{~h} \text {. }\end{array}$} \\
\hline $\begin{array}{l}\text { Ventos } \\
\text { (ver estudo eólico) }\end{array}$ & \multicolumn{2}{|c|}{$\begin{array}{l}\text { Ventos de } 4,5 \mathrm{~m} / \mathrm{s}(16,2 \mathrm{~km} / \mathrm{h}) \text {, são amainados para } 3,2 \mathrm{~m} / \mathrm{s}(11,52 \mathrm{~km} / \mathrm{h}) \text {, porque o prédio } \\
\text { funciona como barreira. }\end{array}$} \\
\hline Comentário & \multicolumn{2}{|c|}{$\begin{array}{l}\text { Excelente implantação, por estar na face norte à frente do edifício; tem boa insolação o } \\
\text { ano todo e fica protegida dos ventos. }\end{array}$} \\
\hline Esplanada & \multicolumn{2}{|c|}{$\begin{array}{l}\text { Entre os dois edifícios há amplo espaço, bem cuidado, com jardins, gramados e bancos. } \\
\text { É um lugar de convívio, para encontros e conversas ao entardecer. }\end{array}$} \\
\hline & Dia nublado e frio $18 \mathrm{~h} 05$ & Dia com sol $11 \mathrm{~h} 10$ \\
\hline Temperatura & $14,0^{\circ} \mathrm{C}$ & $22,0^{\circ} \mathrm{C}$ \\
\hline Termôm & $15,{ }^{\circ} \mathrm{C}$ & $25,0^{\circ} \mathrm{C}$ \\
\hline Umidade Rela & $81 \%$ & $68 \%$ \\
\hline $\begin{array}{l}\text { Insolação } \\
\text { (ver estudos) }\end{array}$ & \multicolumn{2}{|c|}{$\begin{array}{l}\text { No Inverno, durante toda a manhã fica na sombra; a partir das } 13 \mathrm{~h} \text { recebe Sol até o } \\
\text { anoitecer. } \\
\text { No Verão, só } 20 \% \text { da área fica na sombra, todo o restante recebe Sol o dia todo. }\end{array}$} \\
\hline $\begin{array}{l}\text { Ventos } \\
\text { (ver estudo eólico) }\end{array}$ & \multicolumn{2}{|c|}{$\begin{array}{l}\text { Ventos de } 4,5 \mathrm{~m} / \mathrm{s}(16,2 \mathrm{~km} / \mathrm{h}) \text {, por ficarem afunilados entre os edifícios, efeito desfiladeiro, } \\
\text { chegam a } 7,5 \mathrm{~m} / \mathrm{s}(27,0 \mathrm{~km} / \mathrm{h}) \text {. }\end{array}$} \\
\hline Comentário & \multicolumn{2}{|c|}{$\begin{array}{l}\text { Em uma área de estar, de conversar, de contemplar o pôr do Sol, em que a atividade } \\
\text { física é mínima, a tolerância às variações climáticas é muito pequena. Nesta situação, os } \\
\text { ventos são muito incômodos, chegando a ser insuportáveis, principalmente no inverno. } \\
\text { É indispensável instalar barreiras que desviem os ventos para cima e sobrepassem as } \\
\text { pessoas sem incomodar. }\end{array}$} \\
\hline
\end{tabular}

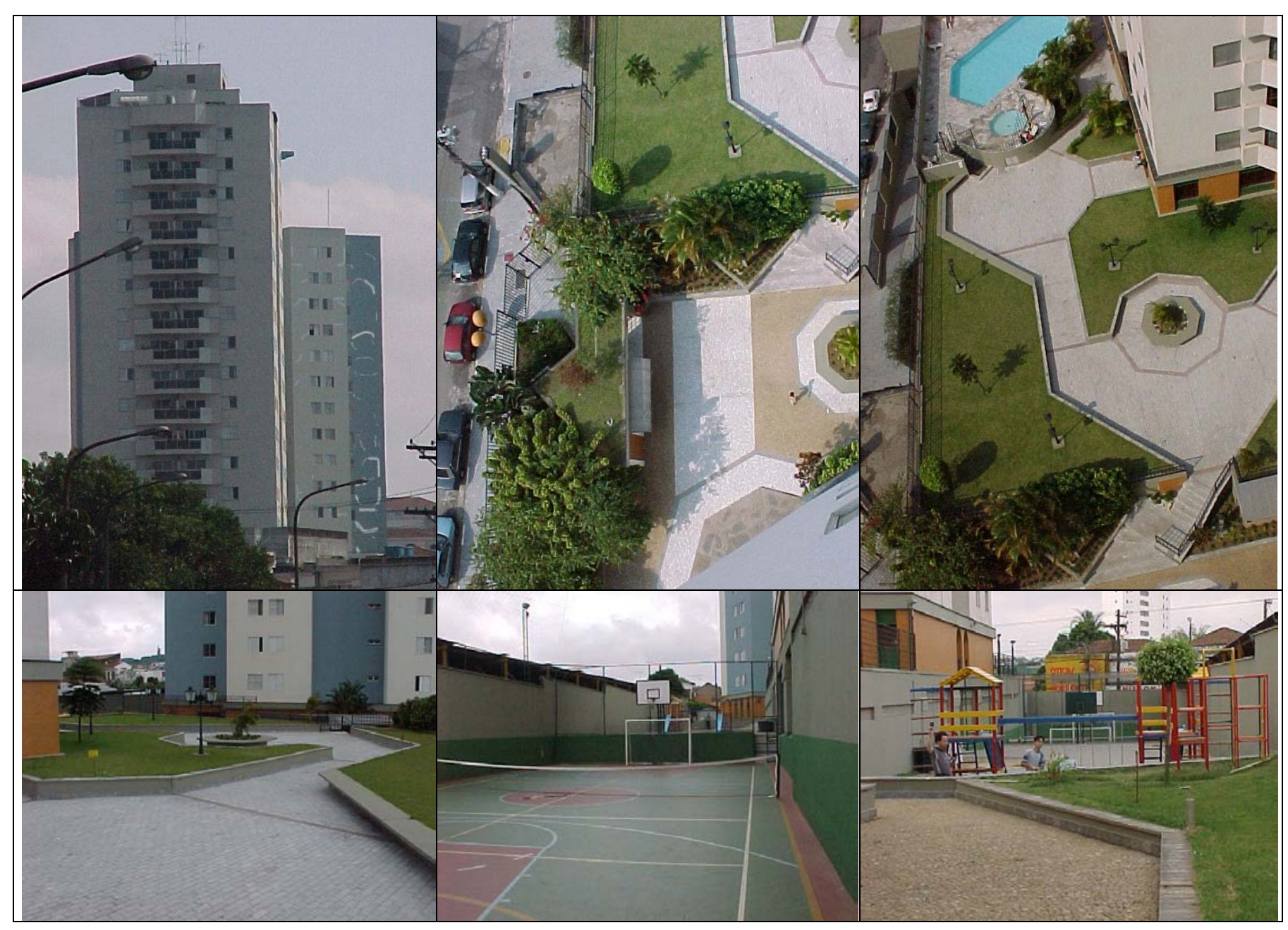


Análise da Qualidade Ambiental nos Espaços Livres

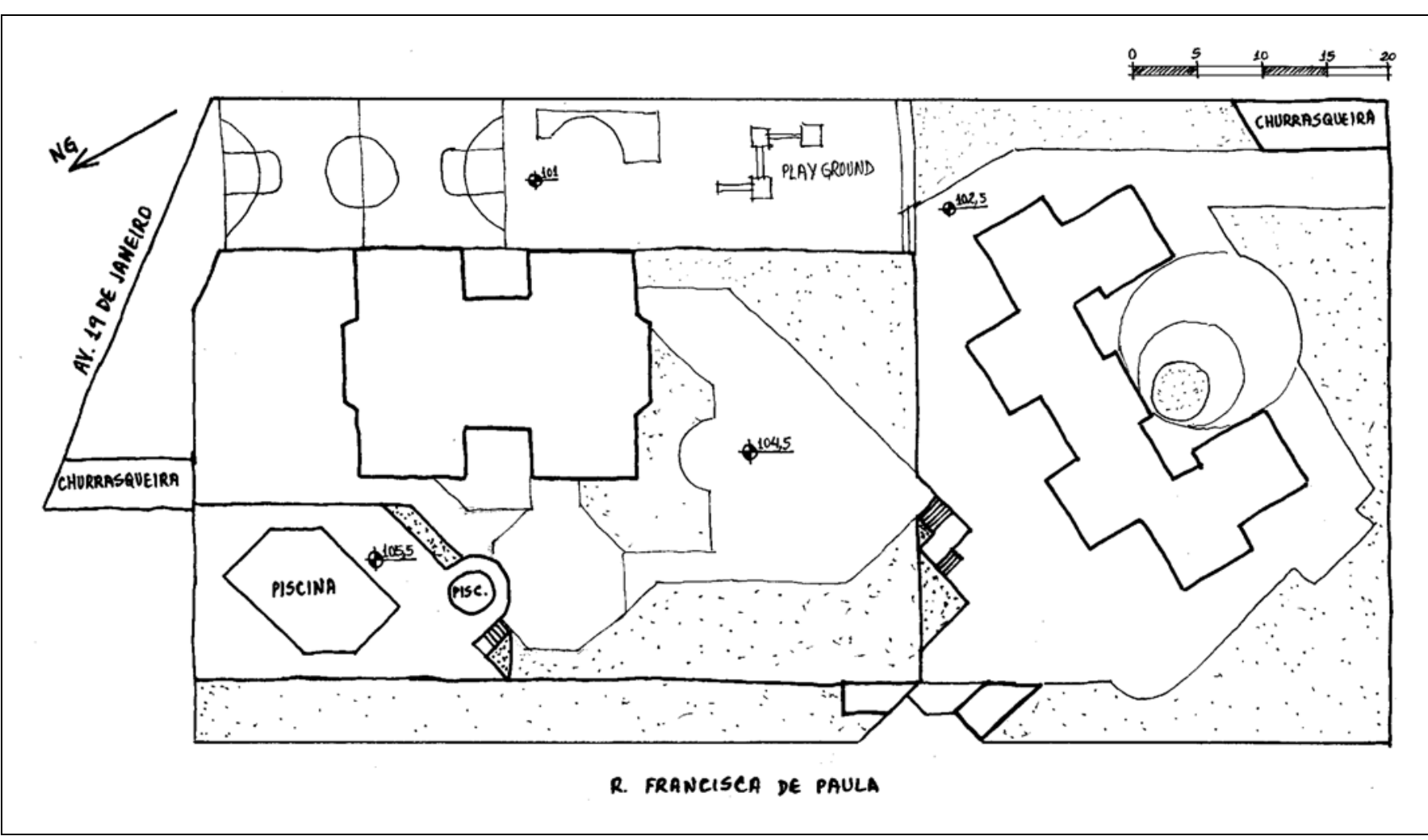

Implantação

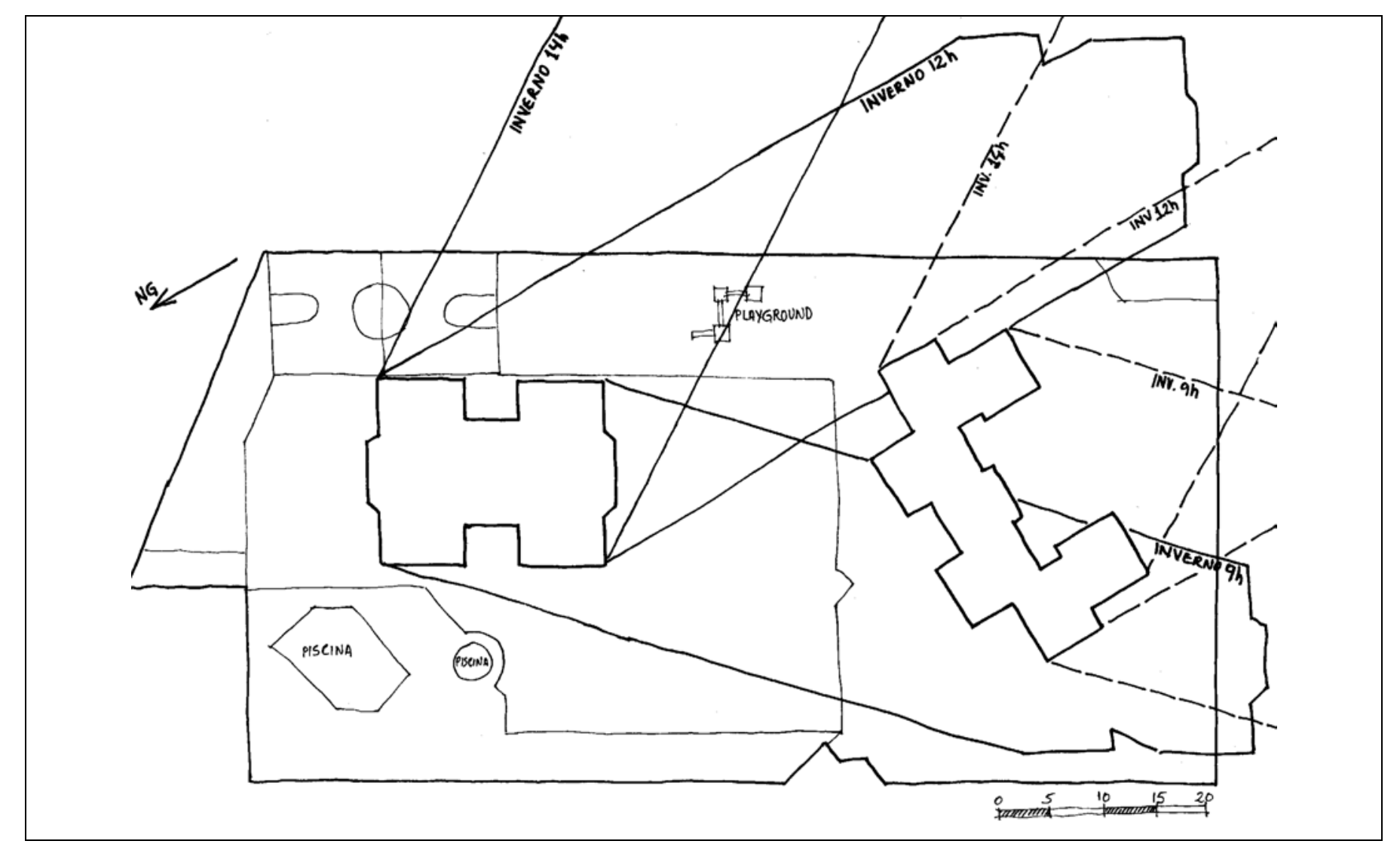

Insolação: sombras produzidas no Inverno às $9 \mathrm{~h}, 12 \mathrm{~h}$ e $14 \mathrm{~h}$

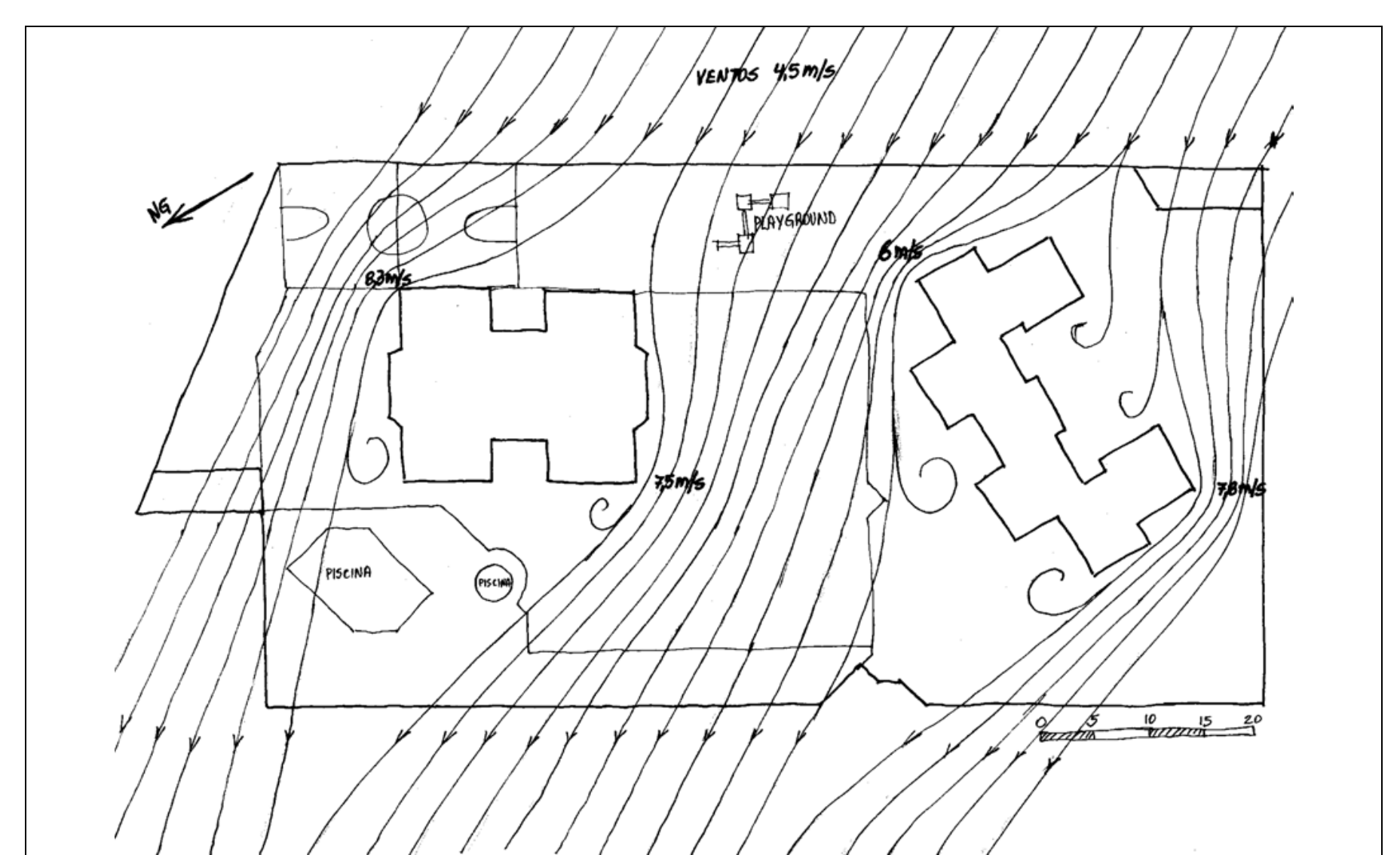

Estudo Eólico: Afunilamento entre os prédios aumenta a velocidade do vento. 